\title{
ARGUMENTACIJA V JEZIKU
}

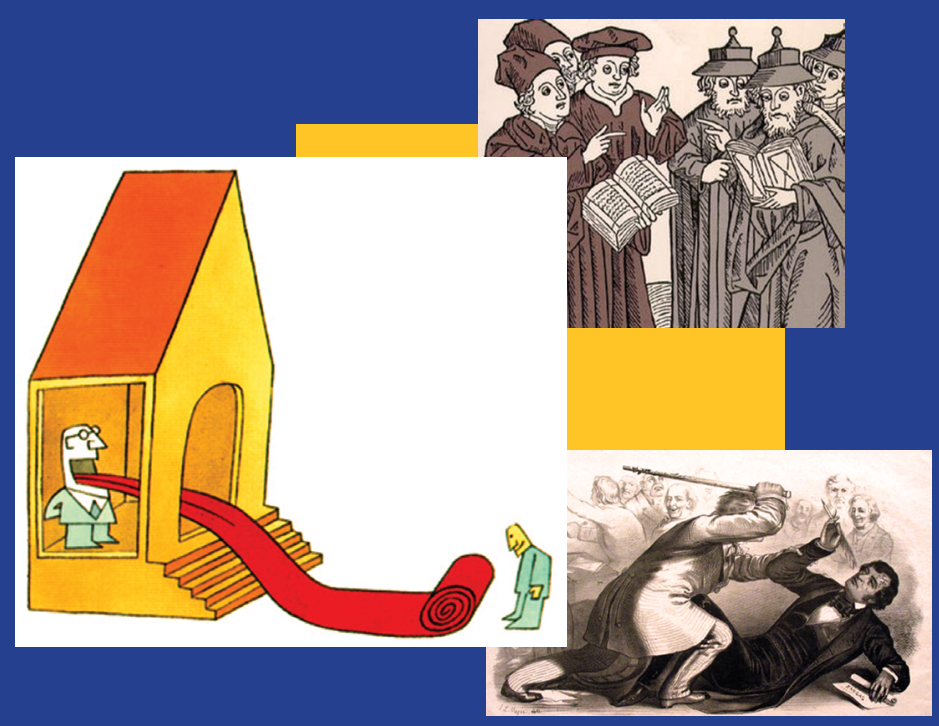



ARGUMENTACIJA

$\mathrm{V}$ J E Z I K U 
- $\theta 0$ 


\section{ARGUMENTACIJA V JEZIKU}


gor Ž. Žagar, Mojca Schlamberger Brezar

Argumentacija $\vee$ jeziku

znanstvena monografija

Digitalna knjižnica

Uredniški odbor: Igor Ž. Žagar (Educational Research Institute \& University of Primorska), Jonatan Vinkler (University of Primorska), Janja Žmavc (Educational Research Institute),

Alenka Gril (Educational Research Institute)

Zbirka: Dissertationes (znanstvene monografije), 4

Glavni in odgovorni urednik: Igor Ž. Žagar

Urednica izdaje: Janja Žmavc

Recenzenta: Andrej Bekeš, Andrej Ule

Oblikovanje, prelom in digitalizacija: Jonatan Vinkler

Založnik: Pedagoški inštitut

Gerbičeva 62, SI-100o Ljubljana

Ljubljana 2009

Za založnika: Mojca Štraus

ISBN 978-961-270-010-2 (pdf)

http://www.pei.si/ISBN/978-961-270-010-2.pdf

ISBN 978-961-270-010-2 (html)

http://www.pei.si/ISBN/978-961-270-010-2/index.html

DOI: https://www.doi.org/10.32320/978-961-270-010-2

(C) 2009 Pedagoški inštitut/Educational Research Institute

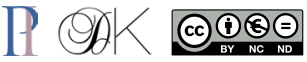

CIP - Kataložni zapis o publikaciji

Narodna in univerzitetna knjižnica, Ljubljana

$81: 1(0.034 .2)$

ŽAGAR, Igor Ž., 1960

Argumentacija v jeziku [Elektronski vir] / Igor Ž. Žagar, Mojca Schlamberger Brezar. - El. knjiga. - Ljubljana : Pedagoški inštitut, 2009. - (Digitalna knjižnica. Dissertationes; 3)

Način dostopa (URL): https://www.pei.si/ISBN/argumentacija-v-jeziku/

ISBN 978-961-270-010-2

1. Schlamberger Brezar, Mojca

247374080 
Nekaj uvodnih pojasnil

I Igor $\check{Z}$. Žagar: Oswald Ducrot in njegova teorija argumentacije v jeziku - izhodišča, vidiki in analitična uporabnost

Argumentacija v jeziku proti argumentaciji z jezikom I5

Informativnost in argumentiranost $\quad$ I5

$\begin{array}{ll}\text { Argumentirati, dokazati, deducirati } & \mathbf{I 7}\end{array}$

Argumentativna usmerjenost $\quad$ I8

Postavka in predpostavka $\quad$ I9

Argumentativne lestvice 2I

Toposi (in topicne forme) $\quad 24$

Med argumentativnimi vezniki in polifonijo $3 \mathbf{I}$

Topoi: črna skrinjica argumentacije $\quad 45$

Ali je kontekst res pomemben? $\quad 69$

Kako napravimo kaj z besedami - polifoni način 8 I

Pa, modifikator veznikov: Argumentativna analiza 95

Logika proti argumentaciji v jeziku 99

Ker pa in sicer pa - analiza $\quad$ I03

$\begin{array}{ll}\text { PRIMER IZ TISKA } & 106\end{array}$ 


$\begin{array}{lc}\text { Hipoteza } & \text { III } \\ \text { ŠE NEKAJ PRIMEROV IZ TISKA } & \text { II5 } \\ \text { Sklepna opažanja } & \text { I24 }\end{array}$

II Mojca Schlamberger Brezar: Slovenski zaznamovalci v luči teorije argumentacije $\mathbf{v}$ jeziku

Slovenski členki med argumentacijskimi operatorji in konektorji $\mathbf{I 2 7}$

Opredelitev členka kot besedne vrste

Clenkizargumentacijsko vrednostjo v govorjenih besedilih

Členki v vlogi operatorjev

ŠE IN ŽE, NASPROTJE V ARGUMENTACIJSKI ORIENTACIJI

SKORAJ, KAR

VSAJ IN TUDI I43

PAČ IN SPLOH I 45

SAMO,LE I48 Sklep 152

In - veznik in konektor 153

Razmejitev pojmov konektor in veznik 153

In med veznikom in konektorjem 158

I $N$ - ZAZNAMOVALEC VEZALNEGA RAZMERJA

ALI KONJUNKCIJE 159

In kot povezovalec oziroma zaznamovalec zgradbe diskurza $\quad$ I63

IN V KOMBINACIJAH Z DRUGIMI PRISLOVI ALI VEZNIKI $\quad \mathbf{6 6 6}$ Toposi, konektorji in argumentacijska gibanja I7I

Topos $\quad$ I7I

Odnos med toposi in konektorji $\quad \mathbf{1 7 6}$

Diskurzivno gibanje $\quad \mathbf{1 7 9}$

Vzročno-posledičniodnos $\quad$ I80

Posledičnipovezovalci $\quad \mathbf{1 8 5}$

Dopustno-protivni ali protiargumentacijski povezovalci I9I

SLOVENSKI DOPUSTNO-PROTIVNI ZAZNAMOVALCI IN DOPUSTNO-PROTIVNO ARGUMENTACIJSKO GIBANJE 
SLOVENSKI PROTIARGUMENTACIJSKI POVEZOVALCI IN NJIHOVA VLOGA V DISKURZU I95

Dejanska argumentacija $v$ analiziranem diskurzu 203

$\begin{array}{ll}\text { Literatura } & 207\end{array}$

Spletni viri $2 \mathrm{I} 4$

Stvarno kazalo 215

Imensko kazalo 219 

njižica, ki je pred vami, v prvem delu prinaša zbir člankov o teori1 -ji argumentacije v jeziku Oswalda Ducrota, ki sem jih v obdobju zadnjih petnajstih let objavil $\mathrm{v}$ različnih revijah in drugih publikacijah. Članki so sicer ustrezno prirejeni tokratnemu namenu objave (pri čemer je glavnino uredniškega dela prijazno opravila dr. Janja Žmavc), ohraniti pa smo želeli tudi »duh časa «, v katerem so nastali. Zainteresirana bralec in bralka bosta zato nedvomno opazila, da je v besedilu govora o argumentativnih členkih, argumentativnih operatorjih in argumentativnih veznikih, za katere danes uporabljam (enotno) poimenovanje argumentativni indikatorji. Stvar razvoja terminologije pač. Težko bo prezreti tudi dejstvo, da na različnih mestih uporabljam podobne ali celo enake primere. To ni naključje, spregled ali šlamparija: podobni ali celo enaki primeri so namreč uporabljeni za pojasnjevanje različnih konceptov in teorij. Pojasnjevanje različnih konceptov in teorij s podobnimi ali celo enakimi primeri pa se mi je zdelo didaktično mnogo primernejše in učinkovitejše, kot da bi si po sili in vedno znova izmišljeval nove (in morda ne najbolj ustrezne).

Drugi del knjige prinaša konkretne analize Mojce Schlamberger Brezar. Tudi Mojca izhaja iz Ducrotove teorije argumentacije v jeziku, četudi se terminologija na trenutke zdi drugačna. Kakor sem že poudaril, se terminologija spreminja, zanimivo vprašanje, ki se pri tem odpira, pa je: ali spreminjanje terminologije ( $v$ našem primeru predvsem kot učinek prestavljanja iz francoščine $\mathrm{v}$ slovenščino) ne pomeni tudi drugačnega »zajetja « predmeta, morda celo »zajetja « drug(ačn)ega predmeta? 
Prav zato sva se odločila, da svoje študije objaviva v isti knjigi. Kot poskus in izziv.

$$
\text { Igor Ž. Žagar }
$$

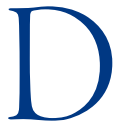

ela J. C. Anscombra in O. Ducrota so močno zaznamovala moje razmišljanje o jeziku, argumentaciji in postopkih argumentiranja z rabo slovničnih sredstev, ki izvirajo zgolj iz jezika samega. Za vodilo pri raziskovalnem delu so mi služila tako pri magistrski nalogi ${ }^{1}$ kot doktorski disertaciji ${ }^{2}-\mathrm{v}$ prvi kot izhodišče za analizo argumentov v pogajalskem sporazumevanju, $\mathrm{v}$ drugi kot podlaga za analizo povezovalcev $\mathrm{v}$ francoskih govorjenih besedilih - televizijskih debatah. Kasneje sem se nanju sklicevala še v številnih člankih, hkrati pa sem upoštevala tudi dela francoskih ter slovenskih raziskovalcev govorjenega diskurza (Roulet, Moeschler in sodelavci, ki izhajajo iz t. i. Ženevske šole, ki se je močno zgledovala po Ducrotovih idejah) in argumentacije (C. Plantin, I. Ž. Žagar).

Pogled na francoske povezovalce iz doktorske disertacije (Schlamberger Brezar 2000) sem v tem delu razširila na slovenske povezovalce v luči argumentacije $v$ jeziku. Vprašanje, katere so tiste male besedice, ki vzpostavljajo razmerja do povedanega (in ki včasih povedo še več o govorcu kot o tem, kar je hotel povedati) oziroma razkrijejo to, česar sploh ni hotel povedati, se je oblikovalo okrog naslednjih razprav:

- kako delujejo členki, ki so ali niso besedna vrsta, kar pa ne vpliva na njihovo vlogo v argumentaciji v jeziku, kjer se pojavljajo kot operatorji ali povezovalci;

- kaj vse zaznamuje veznik, ki v določenih kontekstih deluje tudi kot konektor in s tem pridobiva argumentacijsko vlogo;

- kaj Ducrotova in Anscombrova teorija o toposih lahko prispeva $\mathrm{k}$ pregledu slovenskih vzročnih, posledičnih in dopustnih/protivnih povezovalcev oziroma načinov, kako se združujejo v argumentacijska gibanja.

Ducrot in Anscombre skozi celoten opus delata z izmišljenimi primeri. Tako dokazovanje je značilno za razprave o jeziku, ki so se v Franciji pojavljale od 80. let prejšnjega stoletja dalje in v skladu s teorijo generativne-transformativne slovnice N. Chomskega predpostavljajo, da ni potrebe po izdelavi korpusov, saj naravni govorci sami prepoznajo vse ustrezne rabe v jeziku.

${ }^{1}$ M. Schlamberger Brezar, Zgradba pogajalske komunikacije, magistrska naloga, Ljubljana 1996.

${ }^{2} \mathrm{M}$. Schlamberger Brezar, Skladenjski in pragmatični vidiki povezovalcev v francoskih utemeljevalnih besedilih, doktorska disertacija, Ljubljana 2000. 
Danes so v jezikoslovju drugi časi in na razpolago so računalniško obdelani korpusi za raziskavo pojavitev posameznih jezikovnih vzorcev. Tako sem si pri iskanju primerov in možnih pojavitev pomagala s splošnodostopnim jezikovnim korpusom Fidaplus (www.fidaplus.net). Analizirala sem predvsem pojavljanje členkov in povezovalcev $v$ govorjenih besedilih, ki so dostopna kot transkripcije razprav iz Državnega zbora ali dramskih besedil. Te primere sem dopolnjevala s primeri dialogov iz avtentičnega diskurza posnetkov pogajalskih sporazumevanj, ki so služili za izdelavo magistrske naloge. Na ta način sem skušala ustvariti sliko sodobne rabe odnosnih besed $\mathrm{v}$ argumentacijskih navezavah.

Z Igorjem Ž. Žagarjem oba izhajava iz istih teoretičnih izhodišč, vendar jih on sprejema predvsem kot filozof in pragmatik, jaz pa kot lingvistka. Zato sta si prvi in drugi del v načinu podajanja precej različna. Morda se na trenutke ponavljava pri citiranju izhodišč in primerov, a to je le posledica želje, da se čim bolj avtentično predstavi Ducrotovo misel, ki je služila za odskočno desko razpravam v tej knjigi.

Mojca Schlamberger Brezar 

IGOR Ž. ŽAGAR

OSWALD DUCROT

IN NJEGOVA TEORIJA

ARGUMENTACIJE

V JEZIKU -

IZHODIŠČA, VIDIKI

IN ANALITIČNA

UPORABNOST 



\section{Argumentacija v jeziku proti argumentaciji z jezikom ${ }^{1}$}

rancoski lingvist Oswald Ducrot v razvoju svoje teorije argumentacije loči nekako štiri faze:

- krepko informativistično verzijo,

- šibko informativistično verzijo,

- šibko verzijo argumentacije v jeziku in

- krepko verzijo argumentacije v jeziku, verzijo, ki je bila v 90. letih prejšnjega stoletja v (kritični) fazi nastajanja in preoblikovanja. Namen tega članka je, skozi oris in problematizacijo Ducrotovih temeljnih postavk, prikazati oblikovanje in razvoj teorije argumentacije $\mathrm{v}$ jeziku, njen osnovni konceptualni aparat in (analitični) domet.

\section{Informativnost in argumentiranost}

Osnovna postavka prve, »krepko informativistične « faze je postulat, da sleherno sklepanje, natančneje sleherno argumentiranje za nek sklep, temelji izključno na dejstvih, ki jih posreduje izjava-argument. Če je mogoče iz A(rgumenta) sklepati na S(klep), je to mogoče izključno zato, ker izjava A izjavo $S$ podkrepljuje dejstveno - tako da navaja oziroma prikazuje dejstva, ki govorijo v njen prid - ne pa morda (tudi) kako drugače, na primer strukturno jezikovno. Će lahko na primer z izjavo

\section{(1) Janezje studiralle kako uro.}

argumentiramo za, oziroma jo postavljamo kot argument za sklep

${ }^{1}$ Različica članka z istim naslovom je bila objavljena v reviji Anthropos (1991), III/IV, 172-185. 


\section{(2) Ne bo opravil izpita.}

potem - v skladu s »krepko informativistično « tezo - to (lahko) storimo le na osnovi dejstva, da je Janez za študij porabil le kako uro in pa dejstva, da ura študija za uspešno opravitev izpita ponavadi ne zadostuje, ne pa tudi, na primer, na osnovi argumentativne usmerjenosti prislova le, usmerjenosti, ki je stvar jezika, ne govora, torej semantična. ${ }^{2} \mathrm{~V}$ primeru (1) gre torej za tip argumentacije, ki je povsem nejezikovna oziroma je jezikovna le toliko, kolikor jezik uporablja kot konvencionalno, standardizirano sredstvo komunikacije, kot »medij«, ki ne vpliva na »sporočilo«, ki ga prenaša.

Seveda pa ta spontano-zdravorazumska »teorija « takoj naleti na protiprimere. Recimo, da pripravljamo seminarsko nalogo o mednacionalnih trenjih v posttitovski Jugoslaviji in da nas (zaradi učinkov, ki jih je dosegel) še posebej zanimajo finese Miloševićevega stila; pri svojih družboslovno usmerjenih prijateljih se pozanimamo, kdo bi o stvari utegnil kaj vedeti, in dobimo naslednja dva odgovora:

(3) Janez ni prebral vseh Miloševićevih govorov (Argument). $\rightarrow$ Morda ti ne bo mogel svetovati (Sklep).

in

(4) Marko je prebral nekaj Miloševićevih govorov (Argument). $\rightarrow$ Morda ti bo labko svetoval (Sklep).

Izjavi (3) in (4) izkazujeta očitno neskladje med informativno in argumentativno vrednostjo. Dejstvo, da Janez ni prebral vseh Miloševićevih govorov, na dejstveni, informativni ravni, lahko pomeni tudi, da je prebral vse Miloševićeve govore, razen, morda le enega, dejstvo, da je Marko prebral nekaj Miloševićevih govorov, pa na dejstveni, informativni ravni, lahko pomeni tudi, da je, morda, prebral le enega ali dva Miloševićeva govora. Janez bi bil torej neprimerno primernejši »informator« kakor Marko, a vendar jezik ne dovoljuje argumentiranj $\left(3^{c}\right)$ in $\left(4^{c}\right)$.

(3') *Janez ni prebral vseh Milośevićevih govorov (Argument). $\rightarrow$ Morda ti bo labko svetoval (Sklep).

\footnotetext{
${ }^{2}$ Da je neka jezikovna entiteta argumentativno usmerjena, pomeni, da njena prisotnost $\mathrm{v}$ danem diskurzivnem segmentu postavlja oziroma predstavlja omejitev za nadaljevanje diskurza. Z drugimi besedami, tudi če bi za prislov le postavili »dvajset ur « in ne »kako uro «, bi izjava še vedno argumentirala za negativni sklep. Kar seveda postavlja pod vprašaj tudi dejstvenost »dejstva, da ura študija za uspešno opravitev izpita ponavadi ne zadostuje«. Namreč, koliko ur pa zadostuje za uspešno opravitev izpita, še zlasti če upoštevamo omejevalno vlogo prislova le? Pa o tem več v nadaljevanju.
} 


\section{(4' ) * Marko je prebral nekaj Milośevićevih govorov (Argument). $\rightarrow$ Morda ti ne bo mogel svetovati (Sklep).}

Da bi izjavama $\left(3^{\circ}\right)$ in $\left(4^{\circ}\right)$ lahko odvzeli asteriska (oziroma ju naredili za argumentativno sprejemljivi), bi morali vanju vplesti argumentativno usmerjene modifikatorje, na primer kljub temu ali vseeno $\mathrm{v}\left(3^{\circ}\right)=($ Morda $t i$ bo VSEENO labko svetoval), oziroma le $\mathrm{v}\left(4^{\circ}\right)=($ Marko je prebral LE nekaj Miloševićevih govorov).

Rekli smo, da je jezik tisti, ki ne dovoli argumentativnih navezav ( $\left.3^{c}\right)$ in $\left(4^{\mathrm{C}}\right)$. Kaj natanko to pomeni?

\section{Argumentirati, dokazati, deducirati}

Predvsem to, da argumentirati ne pomeni dokazovati, in pa da argumentacija ne temelji na pravilih logične dedukcije. Mehanizem sklepanja $\mathrm{v}$ primerih (3) in (4) tako ni enak mehanizmu sklepanja v (5)

(5) a. Vsi Slovenci so nacionalisti.

b. Janez je Slovenec.

c. Janezje nacionalist.

Medtem ko gre v (5) za logično podprto sklepanje, za silogizem, v katerem je sklep $c$ nujna posledica premis $a$ in $b$, pa sklepa v primerih (3) in (4) nikakor nista nujna posledica argumentov, ki ju kot sklepa sploh uvajata. Kdo drug bi izjavo Janez ni prebral vseh Miloševićevih govorov lahko uporabil kot argument za povsem drug sklep, na primer, Janez je bedak, ali Bo že še videl, kaj ga čaka, s tem pa bi argumentiral povsem drugače oziroma izvršil povsem drugačno argumentativno dejanje kot govorec oziroma izjavljalec argumentativne navezave (3), vendar pa ne bi bil njegov sklep nič manj utemeljen oziroma upravičen. Za razliko od (logičnega) dokazovanja oziroma deduciranja, ki temelji na poznavanju in spoštovanju logičnih zakonov, temelji argumentiranje (le?) na poznavanju in presoji sveta, realnosti oziroma konkretne situacije, v kateri se govorec nahaja, še zlasti na presoji mesta, ki ga ima v njem (lahko) izjava-argument, ter na presoji (možnih) sklepov, h katerim bi izjava-argument utegnila navajati.

Ena od temeljnih značilnosti argumentiranja je namreč v tem, da ni linearno in uniformno, temveč, nasprotno, polemično, da je z izjavo-sklepom (oziroma natančneje: $\mathrm{z}$ utemeljenostjo argumentativnega odnosa, med izjavo-argumentom in izjavo-sklepom) moč polemizirati, ji ugovarjati, jo izpodbijati, ali pa jo celo nadomestiti z drugo izjavo-sklepom, medtem ko je v primeru logičnega sklepanja to nemogoče: logično sklepanje je linear- 
no in uniformno, sklepov, ki so rezultat logične dedukcije, pa ni mogoče izpodbijati, ali jih - (le) na podlagi našega poznavanja in presoje sveta - celo zamenjati z drugimi sklepi, sicer, preprosto nimamo več opraviti z logično veljavnim sklepanjem.

\section{Argumentativna usmerjenost}

Argumentativni odnos (med izjavo-argumentom in izjavo-sklepom) je torej povsem drugačen od logičnega odnosa (med premisami in sklepom), kar potrjuje tudi dejstvo, da so nekatera diskurzivno povsem sprejemljiva sklepanja, logično povsem nesmiselna. Denimo naslednji konverzacijski drobec: ${ }^{3}$

\section{(6) A: Je večerja že nared? B: Ja, skoraj.}

Logično je takšen dialog povsem nesmiseln. Večerja je lahko bodisi že nared bodisi še ni nared. Lahko je sicer tudi skoraj nared, kar pa, logično vzeto, pomeni, da še ni nared; na vprašanje Je večerja že nared?, torej nikakor ne bi bilo mogoče odgovoriti Ja, skoraj, saj bi s tem povedali nekaj protislovnega, namreč: Ja, večerja še ni nared.

Nasprotno pa je ta dialog povsem sprejemljiv diskurzivno, pragmatično, in to - paradoksalno, kakor se lahko zdi - prav zaradi (problematičnega) prislova skoraj. Argument Večerja je skoraj nared namreč argumentira v prid nekega implicitnega sklepa (sklepa, ki torej sega onkraj eksplicitnega dialoga in ga mora A iz njega povleči sam), npr. Treba je pobiteti, za katerega sicer argumentira tudi (logično »čistejši«) argument Večerja je že nared, pri čemer je argument Večerja je že nared sicer močnejši od argumenta Večerja je skoraj nared, oba pa sta argumentativno enako usmerjena. Z drugimi besedami to pomeni, da na argumentativni lestvici »pripravljenost večerje«

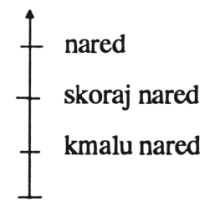

argument Večerja je skoraj nared sicer nastopa kot šibkejši argument, argumentira pa za isti sklep kot (naj)močnejši argument z lestvice. Argumentativna usmerjenost je torej, ne glede na kontekst, vpisana v sam prislov skoraj, kar pomeni, da sleherna izjava-argument, ki vsebuje prislov skoraj, pred-

${ }^{3}$ Sposodil sem si ga v J. Moeschler, Argumentation et Conversation, Éléments pour une analyse pragmatique du discours, Pariz 1985. 
stavlja omejitev za nadaljevanje diskurza: izjava-sklep, ki ji sledi, mora argumentativno ustrezati smeri, ki jo je začrtala oziroma zamejila raba prislova skoraj v izjavi-argumentu.

S tem smo, vsaj delno, tudi že pojasnili nujnost sklepanja v primerih (3) in (4). Pa se vendarle vrnimo za korak nazaj in si postopoma oglejmo, kar smo pridelali v tem morda prehitrem koraku.

\section{Postavka in predpostavka}

Primera (3) in (4), ki smo ju vzeli za ilustracijo razlike med informativnostjo in argumentativnostjo, sta morda sicer zelo nazorna, nista pa najboljša, saj uporabljata leksikalno različna morfema ne vse in nekaj. Problem razlike med informativnostjo in argumentativnostjo pa izstopi v čisti obliki, ko imamo opraviti z leksikalno sinonimnima, argumentativno pa različnima morfemoma. Ducrotov priljubljeni primer, na katerem je zgradil tako rekoč celotno teorijo, je razlika med peu in un peu. Informativno med njima tako rekoč ni razlike, grosso modo oboje pomeni »malo« oziroma zaznamuje majhno količino nečesa.

Do občutne argumentativne razlike pa pride v pragmatični, diskurzivni rabi. Peu namreč argumentira v isti smeri kot nič, un peu pa v isti smeri kot veliko. Zakaj?

Dvojico peu/un peu je v slovenščino sicer težko natančno prevesti, z malce truda pa ji lahko najdemo ustreznika v paru malo/malce. Pri tem nam je v oporo tudi Slovar slovenskega knjižnega jezika, ki za malo pravi (II. zvezek, 677), da izraža majhno stopnjo, za malce pa (II. zvezek, 674), da izraža nedoločeno omejitev povedanega, kar seveda pomeni, da se lahko neomejeno razteza ne samo navzdol, temveč tudi navzgor.

Oglejmo si naslednja dva primera:

(7) Janezje MALO delal. - $\rightarrow$ Nebo uspel (opraviti izpita).

(8) Janezje MALCE delal. - $\rightarrow$ Uspel bo (opraviti izpit).

Opraviti imamo s primeroma, ki na dejstveni, informativni ravni, operirata z majhnima količinama, vendar argumentativno omogočata različne sklepe. Kako to pojasniti?

Ducrot se ju je sprva (v šibki informativistični verziji) lotil s klasično analizo izjav $\mathrm{v}$ postavko in predpostavko. Izjavo

(9) Prešeren je bilvelikpesnik. 
na primer lahko analiziramo $\mathrm{v}$

postavko (p): Prešernovo pesnjenje je bilo nadporprečno. in

predpostavko (pp): Preśeren je bilpesnik.

Za značilnost predpostavke (tako rekoč za test pravilne ločitve predpostavke od postavke) velja, da se ne sme spremeniti niti v primeru, če osnovno izjavo (v našem primeru izjavo (9)) zanikamo, postavimo v vprašalno obliko ali jo vpletemo v odvisnik.

Če na izjavo (9) torej apliciramo naštete pogoje, lahko ugotovimo, da smo predpostavko pravilno razločili od postavke.

Izjave

(9') Prešeren nibil velikpesnik.

(9“) Alije bil Preserenen velik pesnik?

(9“") Slovenci so prepričani, da je bil Preśeren velik pesnik.

načelno ohranjajo predpostavko: Prešerenje bilpesnik. Načelno, ne pa nujno.

Negacija v $\left(9^{\prime}\right)$ bi se namreč prav lahko nanašala na celotno sintagmo velik pesnik in ne le e pridevnik velik, s čimer pa bi zanikala tudi samo predpostavko, da je Prešeren sploh bil pesnik. Z izjavo (9') bi tako brez težav argumentirali za, na primer, Bil je velik prevarant, namreč, Prešeren ni bil velik pesnik (Argument), bil je velik prevarant (Sklep); vse to pa velja tudi za izjavi (9") in (9“").

Ducrot zato uvede nov, odločilen kriterij za ločitev predpostavke od postavke: argumentiramo labko le iz postavke, nikakor pa ne iz predpostav$k e$. Šele po aplikaciji tega pogoja se torej lahko prepričamo, da smo izjavo (9) pravilno razčlenili v postavko in predpostavko: iz Prešeren je bil velik pesnik (Prešernovo pesnjenje je bilo nadpovprečno) namreč brez težav sklepamo na Zato smo mu postavili spomenik, medtem ko argument predpostavke, Prešeren je bil pesnik, za takšen sklep ne zadostuje (vsaj na Slovenskem ne, kar pa seveda ne izključuje možnosti, da je obstaja dežela, kjer postavljajo spomenike vsem, ki so pesniki, ne glede na veličino njihovega pesnjenja).

Ta kriterij je še zlasti odločilen za razlago in razumevanje različne argumentativne moči izjav (7) in (8). Izjavo (7), Janez je malo delal, je tako mogoče analizirati v:

p: kvantiteta Janezovega dela je majhna.

pp: Janezje delal. 
izjavo (8), Janezje malce delal, pa v:

p: Janezje delal.

pp: kvantiteta Janezovega dela je majhna.

S tem ohranimo informativno komponento obeh izjav (kvantiteta Janezovega dela je majhna), z diskurzivno omejitvijo, da je mogoče argumentirati le iz postavke, ne pa tudi iz predpostavke, pa je pojasnjena tudi njuna različna argumentativna moč.

Vendar pa se problem informativnosti s tem vrača nekako skozi zadnja vrata. Očitno je, da malce argumentira v isti smeri kot veliko, malo pa v isti smeri kot nič, in da za sklep Uspel bo (opraviti izpit), argumentirata takoJanezje malce delal, kot Janez je veliko delal, za sklep Ne bo uspel (opraviti izpita), pa tako Janez je malo delal, kot Janez ni delal. Razlika je le v stopnji, $\mathrm{v}$ moči argumenta, tako da lahko argument Janez je malce delal, brez težav povzamemo in okrepimo z Janez je malce delal, celo veliko, argument Janez je malo delal, pa z argumentom Janez je malo delal, celo (splob) nic.

$S$ tem pa na nek način ponovno pride do neskladja na dejstveni, informativni ravni: malo je vendar le nekaj in ne nič, prav kakor je malce, na dejstveni ravni, le nekaj, in ne veliko.

Prav ta problem je Ducrota napeljal h konstrukciji tretje verzije teorije argumentacije, ki jo je, za vnazaj, poimenoval »šibka verzija teorije argumentacije $v$ jeziku /poudaril I. Ž. Ž. $/ \ll$.

\section{Argumentativne lestvice}

Pomembna distinkcija, ki jo Ducrot uvede na tej stopnji, je razlikovanje med stavkom in izjavo na eni, ter pomenom in smislom na drugi strani.

Stavek je zanj shematična, abstraktna konstrukcija in s tem stvar jezi$\mathrm{ka}$ (v saussurovskem smislu), izjava pa njegova vsakokratna realizacija, torej stvar govora. Z drugimi besedami to pomeni, da je izjava nekaj neponovljivega in vsakokrat nova, da torej ni dveh izjav, ki bi bili enaki, četudi se nizi izgovorjenih besed zdijo identični: vsaka izjava je proizvod nekega konkretnega, posameznega dejanja izjavljanja in kot taka neponovljiva.

Na par stavek/izjava se veže konceptualni par pomen/smisel: pomen je semantična vrednost stavka, smisel pa semantična vrednost izjave. Vendar pa Ducrot (in v tem je njegova inovacija) pomena (stavka) ne opredeli kot del smisla, kot je pogosto v navadi, namreč $\gg$ smisel = pomen + kontekst «, temveč, nasprotno, kot skupek navodil, napotkov oziroma nasvetov, ki naj nam pomagajo razvozlati smisel izjav, ki so realizacije danega stavka. Stavč- 
ni pomen nas torej usmerja pri pravilni interpretaciji izjave, ki je njegova vsakokratna realizacija, še zlasti pri iskanju informacij, ki jih moramo zato, da bi bila interpretacija pravilna, iskati v kontekstu. Kaj to pomeni?

Oglejmo si še enkrat primer (6)

(6) A:Je večerja že nared?

B: Ja, skoraj.

Rekli smo že, da argument Večerja je skoraj nared, argumentira v prid nekega implicitnega sklepa, npr. Treba je pohiteti, za katerega sicer argumentira tudi argument Večerja je že nared, pri čemer je argument Večerja je že nared sicer močnejši od argumenta Večerja je skoraj nared, oba pa sta argumentativno enako usmerjena.

Ducrot za interpretacijo izjav stavka /Večerja je SKORAJ nared/ predlaga konstrukcijo stavčnega pomena, ki je sestavljen iz a) informativnih (deskriptivnih) navodil in b) argumentativnih navodil. Izjave stavka /Većerja je skoraj nared/ lahko potemtakem pravilno interpretiramo le, če sledimo navodilom njegovega (stavčnega) pomena:

informat. navodila: določiti oziroma dogovoriti se je treba za neko majhno časovno količino E; izjava je resnična, če večerja še ni pripravljena in če je časovna razlika med izjavljanjem Večerja je $S K O R A J$ pripravljena in pripravljenostjo večerje enaka $E$.

argument. navodila: poiskati je treba nek sklep $\Gamma$, za katerega lahko argumentira tudi izjava Večerja je že nared, na primer Pohiti!

Naša primera z malo (7) in malce (8) bi torej lahko interpretirali takole:

(7) Janezje malo delal. $\rightarrow$ Ne bo uspel (opraviti izpita).

informat. navodila: določiti oziroma dogovoriti se je treba za neko količino dela $E$, ki lahko oziroma še lahko velja za majhno. Izjava

(7) je resnična, če Janez ni presegel te količine.

argument. navodila: poiskati je treba nek sklep $\Gamma$, za katerega je lahko argument tudi (močnejša) izjava Janez ni delal, na primer $N e$ bo uspel (opraviti izpita).

Izjava (8) z izjavo (7) deli informativno, ne pa tudi argumentativno navodilo:

(8) Janez je malce delal. $\rightarrow$ Uspel bo (opraviti izpit). 
informat. navodilo: določiti oziroma dogovoriti se je treba za neko količino dela E, ki lahko oziroma še lahko velja za majhno. Izjava (8) je resnična, če Janez ni presegel te količine.

argument. navodilo: poiskati je treba nek sklep $\Gamma$, za katerega je lahko argument tudi izjava Janez je veliko delal, na primer Uspel bo (opraviti izpit).

S tem Ducrot argumentiranje sicer utemelji (tudi) na informativnem, dejstvenem, obenem pa že omogoči regulacijo informativnega s tistim povsem argumentativnim v jeziku (sintagma »argumentacija $v$ jeziku« meri prav na to, na dejstvo, da je argumentativna usmerjenost vpisana že v jezik sam (jezik kot abstraktno, saussurovsko strukturo) in da ni (le) posledica učinkovitega konteksta). Kljub takšni kompromisni rešitvi pa je takoj opazno dvoje:

1. Da deskriptivna, informativna navodila, za potek same argumentacije, to je za prehod k sklepu, niso pomembna, ali z drugimi besedami: dejstvenost oziroma resničnost izjave-argumenta (njeno sovpadanje s stanjem t.i. »objektivne realnosti«) za usmeritev argumentacije ni odločilna, in nad njo povsem prevladajo argumentativna navodila.

2. Narava argumentov je skalarna, gradualna oziroma stopnjevita. So argumenti, ki sicer argumentirajo za isti sklep, vendar šibkeje od nekaterih drugih argumentov (»skoraj pripravljena «, »že pripravljena «); zato Ducrot skoraj in nekatere druge členke (na primer $\check{z} e$ in $\check{s} e$ ) poimenuje kot argumentativne spremenljivke. Uvrščajo se sicer na iste argumentativne lestvice, a na različna mesta, na primer:
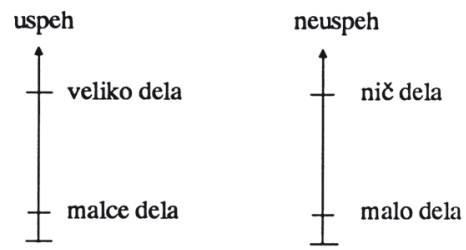

$S$ prevlado argumentativnosti nad informativnostjo in izpostavo skalarne narave argumentov pa so dani tudi že vsi nastavki za prehod v (zaenkrat) zadnjo, krepko teorijo argumentacije v jeziku, katere temeljna koncepta sta topos in polifonija. ${ }^{4}$

${ }^{4}$ Ker bomo polifonijo predstavili na drugem mestu, se bomo tokrat omejili le na topose. Prim. tudi I. Ž. Žagar, Zagatnost performativnosti ali kako obljubiti, Ljubljana 1989, 173-176. 


\section{Toposi (in topične forme)}

Prehod v krepko teorijo argumentacije v jeziku pomeni radikalen prelom s poprejšnjimi teorijami oziroma fazami teorije argumentacije $\mathrm{v}$ jezi$\mathrm{ku}$, in to ne le konceptualno, temveč tudi terminološko. Ta prelom je razviden že kar iz obeh temeljnih postavk Ducrotove zadnje faze teorije argumentacije v jeziku:

1. Ko prehajamo od A(rgumenta) k S(klepu), temelji ta prehod na toposih, splošnih, (neki skupnosti) skupnih in skalarnih strukturah tipa

$$
\text { Boljko P, boljQ }
$$

oziroma

$$
\text { ManjkoP, manj Q }
$$

2. Argumentativna vrednost izjav povsem prevlada nad njihovo informativno vrednostjo (informativna vrednost se iz argumentativne vrednosti celo izpeljuje), povsem informativne izjave pa dobijo jezikovno marginalen status.

$\mathrm{Z}$ drugimi besedami bi lahko prehod iz »šibke « v »krepko《 verzijo argumentacije $\mathrm{v}$ jeziku opisali takole: $\mathrm{v} \gg$ šibki fazi argumentacije $\mathrm{v}$ jeziku argumentacija še temelji na dejstvih, toda pod nadzorom argumentativnih navodil, vezanih na pomen stavka.

$\mathrm{V} \gg k$ repki«fazi pa argumentativno informativnega ne nadzoruje več, temveč prevzame njegovo mesto: informativno postane ne le povsem podrejeno argumentativnemu, temveč iz njega celo izpeljano. Če je namreč argumentacija (argumentativna usmerjenost) v jezik že vpisana, potem so izjave, ki realnost le opisujejo ali o njej poročajo, jezikovno povsem nepertinentne: jezik uporabljajo le kot medij prenosa. Č pa je argumentacija v jezik (res) že vpisana, ta medij nikakor ne more biti (argumentativno) nevtralen: argumentativne spremenljivke, na primer, ki so leksikalno sicer »prazne«, dajejo diskurzu neko povsem določeno smer, ne glede na predstavno oziroma informativno vsebino, ki jo diskurz prenaša.

Tisto, kar res temeljno opredeljuje krepko verzijo argumentacije v jezi$\mathrm{ku}$, pa je seveda vpeljava toposov.

Kaj pomeni, da je topos a) splošen in b) skupen (koncept skalarnosti smo vpeljali že na primeru argumentativnih lestvic)?

To, da gre a) za splošno (in obenem zelo abstraktno) shemo oziroma matrico (na neki način morda celo za pravilo), ki omogoča množico partikularnih sklepov, ki pa niso obvezni oziroma zavezujoči na način silogiz- 
ma ali logične dedukcije. Topos, oziroma natančneje sklicevanje na topos, lahko neki sklep le omogoči, ne pa k temu sklepu zaveže. Zato naš sogovorec (s tem pa smo že pri točki b)) sicer lahko priznava veljavnost toposa, ki smo ga pri sklepanju uporabili, pa se z našim sklepom vendarle ne bo strinjal. Situaciji primernejši se mu bo zdel pač kak drug topos in na njem bo utemeljil svoj sklep.

Trditev, da so toposi b) skupni (neki skupnosti), pomeni le, da neka skupnost priznava njihovo veljavnost oziroma natančneje veljavnost in upravičenost sklepov, ki na njih temeljijo, ne pa tudi, da bi vsi pripadniki te skupnosti v enaki situaciji uporabili enak topos! Uporabo nekega toposa oziroma sklep, ki ga ta topos omogoča, je mogoče vedno izpodbijati (narava argumentacije je pač temeljno polemična), vendar le $z$ aplikacijo nekega drugega toposa oziroma $\mathrm{z}$ argumentiranjem za sklep, ki ga ta drugi topos podpira.

Če poskušamo teorijo toposov aplicirati na naša primera (7) in (8)

(7) Janezje malo delal. $\rightarrow$ Ne bo uspel (opraviti izpita).

(8) Janez je malce delal. $\rightarrow$ Uspel bo (opraviti izpit).

potem lahko ugotovimo, da izjava (7) aplicira oziroma se sklicuje na neki topos kot

\section{TI Manjkodelamo, manjsije uspeh.}

in da ta topos aplicira šibko, medtem ko izjava (8), prav tako šibko, aplicira neki topos kot

\section{T2 Večkodelamo, večjije uspeh.}

Kaj to pomeni, zakaj pravimo, da izjavi (7) in (8) aplicirata toposa T1 in T2 šibko? Kako naj »šibko« in njegov protipol »močno« sploh definiramo?

Ducrot ju za začetek, nekako hevristično, opredeli takole:

- močno pomeni topos aplicirati tako, da je le malo argumentov, ki bi bili močnejši od uporabljenega;

- šibko pomeni topos aplicirati tako, da je le malo argumentov, ki bi bili šibkejši od uporabljenega. 
Inče si ogledamo naši argumentativnilestvici »uspeha « in »neuspeha«
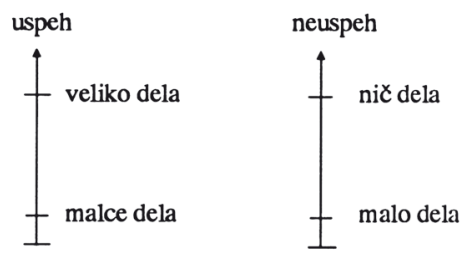

vidimo, da je dispozitiv hevristično povsem uporaben: če je namreč lestvica le dvostopenjska, potem ima dani topos pač lahko le dve vrednosti, močno in šibko.

Toda, ali je mogoče dispozitiv močno/šibko definirati lingvistično strožje?

Vzemimo, da imamo dvodelen argument; prvemu delu argumenta recimo A, drugemu pa B. Rekli bomo, da v tem primeru veljata naslednji definiciji:

1. A je močnejši argument od $\mathrm{B}$, če velja: $B$, in celo $A$.

2. B je šibkejši argument od A, če velja: $A$, in v najboljšem/najslabšem primeru $B$.

Zdaj pa ti dve definiciji preverimo na dveh konkretnih primerih:

A

$\mathrm{B}$

(10) Tojeprehlad ali v najslabsem primeru gripa. $\rightarrow$ Bodite brez skrbi.

A

$\mathrm{B}$

(11) Tojepljućnica ali v najboljsem primeru huda gripa. $\rightarrow$ Pazite se!

Izjava (10) aplicira neki topos kot:

T3 Manjkosmo bolni, manj je vzrokaza zaskrbljenost.

izjava (11) pa neki topos kot:

\section{T4 Boljkosmobolni, boljsmolahko zaskrbljeni.}

Argumenta A sta, glede na našo definicijo, močnejša kot argumenta B, kar pomeni, da, če dani sklep sledi iz B, potem mora slediti tudi iz A. Z drugimi besedami to pomeni, da obe izjavi aplicirata »svoja « toposa močno, ali natančneje: glede na argumentativni lestvici, ki ju lahko konstruiramo v skladu z našim poznavanjem moči argumentov v obeh izjavah, 

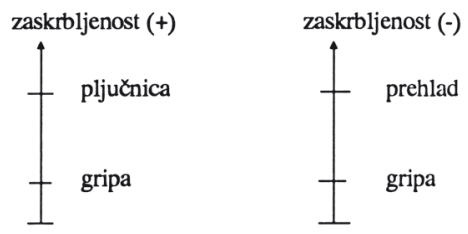

lahko rečemo, da obe izjavi aplicirata »svoja《 toposa $v$ smeri argumentativnih lestvic, da torej težita $\mathrm{k}$ močnejši aplikaciji toposov.

Zdaj pa zamenjajmo argumentativni spremenljivki: namesto $v$ najboljšem primeru oziroma $v$ najslabšem primeru, uporabimo celo, tako da dobimo:

\section{A $\quad$ B}

$\left(10^{\circ}\right)$ To je preblad, celogripa. $\rightarrow$ Pazite se!

(11') Toje pljucnica, celo (huda) gripa. $\rightarrow$ Pazite se!

V skladu z našima definicijama močne in šibke aplikacije toposov, vpeljava argumentativne spremenljivke celo nam zamenja (obrne) moč argumentov (B je zdaj močnejši kot A), s tem pa tudi samo argumentativno usmeritev! Iz argumenta To je prehlad, celo gripa, ne moremo več sklepati Bodite brez skrbi, temveč le Pazite se, kar je tudi povsem v skladu z argumentativno lestvico zaskrbljenosti (-), na kateri se gripa nahaja nižje kot prehlad in s tem (ker je lestvica negativna) bližje vzroku za zaskrbljenost.

$\mathrm{Z}$ drugimi besedami in eksplicitneje: $\mathrm{z}$ zamenjavo argumentativnih variabel postane očitno, da je argumentativna lestvica zaskrbljenosti (-) pravzaprav le zrcalna preslikava argumentativne lestvice zaskrbljenosti (+), pri čemer zamenja oziroma izgubi svojo usmeritev nekako takole:

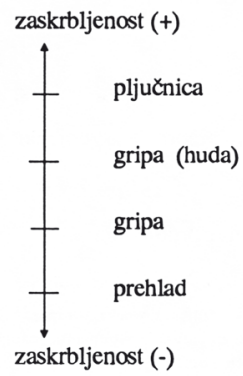

To seveda pomeni, da na isti (razširjeni) argumentativni lestvici lahko apliciramo oba toposa, tako T3 kot T4; katerega bomo izbrali oziroma natančneje, katerega nas bo jezik prisilil izbrati, pa je odvisno od uporabljene argumentativne spremenljivke. Videli smo namreč, da je zamenjava argu- 
mentativne spremenljivke v (10), dobljenemu argumentu v (10`) dala drugačno (argumentativno) usmeritev, kar obenem tudi pomeni, da (10`) ne aplicira več toposa T3 temveč topos T4.

Da naša trditev o odločilni vlogi (izbire) argumentativne spremenljivke ni pretirana, priča prav »preobrazba« primera (11). Kaj se po zamenjavi spremenljivke zgodi z (11)? Celo »(hudi) gripi«, ki je na argumentativni lestvici nižje od pljučnice, $s$ sàmo svojo prisotnostjo v izjavi, to je $z$ argumentativno usmeritvijo, ki je vanjo vpisana, podeljuje vrednost močnejšega argumenta in s tem napeljuje k sklepu Pazite se. Argumentativna usmeritev, vpisana v celo, namreč ne dopušča, da bi bil argument, ki mu sledi šibkejši od onega, ki mu predhaja; nasprotno, celo z argumentom, ki ga uvaja (torej z argumentom, ki sledi (argumentativni) spremenljivki celo), le potencira moč predhodnega argumenta.

Če se hočemo torej izogniti aplikaciji nekega toposa T3' Manj ko smo bolni, več je vzrokov za zaskrbljenost (ki sicer morda je splošen, nikakor pa ne skupen) in s tem ponovno vzpostaviti argumentativno ravnovesje, moramo v $\left(11^{\prime}\right)$ vpeljati dodatno argumentativno spremenljivko, na primer:

(11") To je pljučnica, celo LE hudagripa. $\rightarrow$ Bodite brezskrbi.

ali celo (!)

\section{$\left(11^{\prime \prime)}\right.$ To je pljucnica, MORDA celo LE hudagripa. $\rightarrow$ Bodite brezskrbi.}

Če le blaži in sprevrača argumentativno usmerjenost celo, pa morda argumentativno blaži morebitno logično nasprotje med priredno postavljenima trditvama. Če gre namreč v nekem primeru za pljučnico, potem pač ne gre za (hudo) gripo, in obratno; če pa obe trditvi »tamponiramo « z mor$d a$, jima s tem odvzamemo status trditev, s tem pa ju postavimo tudi izven dvovalentnega logičnega sistema, v katerem sta lahko (le) bodisi resnični bodisi neresnični. ${ }^{5}$

${ }^{5}$ Ducrot pozna tudi srednje močno oziroma srednje šibko aplikacijo nekega toposa. Omenjam jo zato, ker prav srednje močna aplikacija nekega toposa izvrstno kaže na prevlado argumentativnega nad informativnim in pa zato, ker v tako rekoč čisti obliki izstopita vloga in pomen (funkcija) argumentativnih spremenljivk kot spremenljivk.

Oglejmo si naslednja dva » pivska « primera:

(12) Steklenica je ŽE na pol prazna. $\rightarrow$ Treba bo odpreti drugo.

ki aplicira neki topos kot

T5 Boljkose pije, več pijače je potrebne. in

(13) Steklenica je ŠE na pol prazna $\rightarrow$ Ne boše treba odpreti druge. 
Seveda pa z osnovnima topičnima shemama

$$
\begin{array}{ll}
T 1 & +P,+Q \\
T 2 & -P,-Q
\end{array}
$$

analize ni mogoče prignati prav daleč. Že tako preprosta argumentativna navezava kot

$$
\text { (14) Ne troši toliko! (Sklep) } \rightarrow \text { Ostalbošbrez denarja (Argument) }
$$

jima namreč povzroči tako rekoč nepremostljive probleme.

Koncept toposa je zato primerneje fleksibilneje definirati kot splošno, skupno in skalarno strukturo, ki povezuje dve argumentativni lestvici Q in $\mathrm{P}$, osnovni topični shemi pa »razlomiti « $\mathrm{v}$ štiri topične forme

$$
\begin{array}{ll}
T 1 & +Q,+P \\
& -Q,-P \\
& \\
T 2 & +Q,-P \\
& -Q,+P
\end{array}
$$

O tem pa v nadaljevanju.

ki aplicira neki topos kot

$$
\text { T6 Manjkosepije, manj pijače je potrebne. }
$$

Neka izjava, pravi Ducrot, aplicira neki topos Tx srednje močno, če istočasno dovoljuje tudi aplikacijo Ty, ki ga prav tako aplicira srednje močno, kar velja tako za izjavo (12) kot za izjavo (13). Propedevtična lepota »srednje močnih aplikacij« pa je v tem, da pri njih v čisti obliki izstopi razlika med informativnim in argumentativnim (v jeziku): že na pol prazna in še na pol polna namreč » poročata « o informativno istem stanju, o nivoju tekočine v steklenici, ki je tako v primeru že na pol prazna kot v primeru še na pol polna isti, povsem nasprotna pa je njuna argumentativna usmerjenost in s tem sklepa, h katerima napeljujeta.

Že ob analizi primerov (10) in (11) smo pokazali, da je argumentativna usmerjenost neke izjave tako rekoč povsem odvisna od njene argumentativne spremenljivke, analiza primerov (12) in (13) pa jih izpostavlja prav v njihovi vrednosti spremenljivke.

Sintagmi že na pol prazna in še na polpolna na primer aludirata na dejavnost praznjenja, ne polnjenja. Zdaj pa obema spremenljivkama ( $\check{z} e, \check{s} e)$ zamenjajmo mesto, tako da dobimo še na polpraz$n a$ in že na pol polna. Zaradi zamenjave dveh neznatnih, predvsem pa leksikalno praznih spremenljivk, obe na novo dobljeni sintagmi ne le da argumentirata za drugačen sklep kot pred zamenjavo, še več: $\mathrm{z}$ zamenjavo argumentativnih spremenljivk tako rekoč preskočimo $\mathrm{v} \gg$ drug vic«: zdaj namreč nimamo več opraviti s procesom praznjenja, temveč s procesom polnjenja! 



\title{
Med argumentativ- nimi vezniki in polifonijo
}

\author{
Esej iz intuitivne \\ epistemologije $\mathrm{e}^{\mathrm{l}}$
}

\begin{abstract}
$\mathrm{F}$ rancoski lingvist Oswald Ducrot že skoraj tri desetletja razvija novo, 1 drugačno, teorijo argumentacije, »teorijo argumentacije v jeziku « (TAJ), s katero raziskuje argumentativni potencial jezika kot sistema. $S$ TAJ želi pokazati, da so v jezik kot sistem že vpisane določene argumentativne lastnosti, da lahko jezik na nekaterih ravneh argumentira sam po sebi, obenem pa naši, dialoški in interaktivni argumentaciji vsili določene omejitve.
\end{abstract}

Teorijo argumentacije v jeziku bi, kakor smo pojasnili že v prejšnjem članku, lahko povzeli v treh osnovnih, soodvisnih trditvah:

Argumentativno v jeziku prevladuje nad informativnim (oziroma $\gg$ dejstvenim «).

I. Semantični opis neke izjave je odvisen od (njenih) možnih nadaljevanj, ne pa od njenega razmerja do »dejstev«.

II. V argumentativnih nizih ((A)rgument > (S)klep) je semantična vrednost argumenta in sklepa odvisna od njunega medsebojnega razmerja.

Naj zgoraj navedene trditve ilustriram s pomočjo nekaj primerov. Recimo, da nam sogovornik pravi:

\section{(1) Uraje osem.}

Je to argument? Le zakaj bi nam želel kdo povedati, da je ura osem? Zgolj zato, da bi vedeli, koliko je ura? Malo verjetno, razen če smo ga pov-

\footnotetext{
${ }^{1}$ Različica članka je bila predstavljena na 6. Mednarodni konferenci iz jezikovne pragmatike, ki je v organizaciji International Pragmatics Association (IPrA) julija 1998 potekala v Reimsu (v Franciji), in pod istim naslovom objavljena v reviji Anthropos 32 (2000), 1/2, 81-92.
} 
prašali po točnem času. Če pa nas točen čas ne zanima in nam nekdo kljub temu pravi (1), kakšen bi utegnil biti njegov namen?

Človek, ki nam je rekel (1), je želel s to izjavo očitno povedati nekaj povsem drugega. Toda kaj? H kakšnim (diskurzivnim) nadaljevanjem lahko izjava (1) napeljuje? V katero smer argumentira? Kaj lahko iz nje sklepamo? Ker ne poznamo natančnega konteksta, ${ }^{2} \mathrm{v}$ katerem je bila izrečena, lahko sklepamo na precej različnih možnosti:

(1) Ura je osem. $\rightarrow$ Pohiti!

$\rightarrow$ Vzemi si čas!

$\rightarrow$ Prižgi radio!

$\rightarrow$ Pojdi si umit zobe!

Če pa vizjavo (1) vpletemo prislova že in šele, kot:

(1') Ura je že osem.

in

(1") Ura je šle osem.

potem, ceteris paribus, primera $\left(1^{`}\right)$ ne moremo več speljati v sklep: »Vzemi si čas! «, kot v primeru (1), ampak le v sklep: »Pohiti!«. Po drugi strani pa iz (1“) ne moremo več sklepati na: »Pohiti!«, ampak le na: »Vzemi si čas! «. In zakaj bi morali biti ob tem dejstvu presenečeni? Zato, ker (1), (1') in (1") govorijo o popolnoma istem kronološkem dejstvu - namreč, da je ura osem -, pri čemer (1) lahko napeljuje na povsem različne (sklepe), medtem ko (1') dovoljuje le sklepe, ki napeljujejo na poznost, (1“) pa sklepe, ki napeljujejo na zgodnost.

Toda kako je to sploh mogoče, če (1), (1') in (1") govorijo o istem kronološkem dejstvu in je osnova (1), (1') in (1") isto stanje stvari? No, zato, ker prav to »isto stanje stvari« gledamo iz različnih zornih kotov, iz različnih perspektiv. V primeru (1 $1^{\circ}$ ) osmo uro vidimo (in jo diskurzivno tako tudi predstavimo) kot pozno, v primeru (1“) pa kot zgodnjo. Takšno razlikovanje v okviru istega stanja stvari lahko povzroči že preprosta vpeljava dveh argumentativnih veznikov, ${ }^{3} \mathrm{v}$ našem primeru dveh prislovov. $\mathrm{V}$ primeru $\left(1^{\circ}\right)$ prislov že naš sklep usmeri v smer »poznosti« ne glede na to, o

${ }^{2}$ Pokazati bom med drugim skušal, da je vloga konteksta v lingvistični analizi pogosto precenjena. Osnovne poteze konteksta daje že izjava (ali celo stavek kot abstraktna jezikovna struktura) sama: kontekst (lahko) dano izjavo sicer (pre)interpretira, toda izjava že sama ustvari svoj osnovni kontekst. Podrobneje o tem pišem v poglavju z naslovom Ali je kontekst res pomemben?.

${ }^{3} \mathrm{~V}$ nadaljevanju, »vezniki«. 
katerem delu dneva (katerem času) v nadaljevanju govorimo. Podobno velja tudi za primer $\left(1^{\prime \prime}\right)$, le da nas ta navaja na sklep o $\gg$ zgodnosti $\ll$. Dejanski čas je, zaradi uporabe teh specifičnih jezikovnih sredstev, v obeh primerih nepomemben.

To pa, z drugimi besedami povedano, pomeni, da mora biti argumentativna usmeritev $\mathrm{v}$ poznost ali zgodnost na neki način že vpisana $\mathrm{v}$ obe leksikalni enoti jezikovnega sistema. Naj pojasnim, kaj hočem reči, s pomočjo še enega primera. Recimo, da smo soočeni z izjavo kot:

\section{(2) Janez je delal.}

Na kakšen sklep napeljuje ta izjava: pozitiven, $(+)(\gg$ Uspelo mu bo.«) ali negativen, $(-)(» \mathrm{Ne}$ bo mu uspelo.«) ? Prepričan sem, da bi se vsakdo odločil za pozitiven sklep, saj beseda $\gg$ delo $\ll$ implicira, da je v nekaj bil vložen določen trud; in če je v nekaj bil vložen določen trud, potem je verjetneje, da bo tisti, ki se je trudil, uspel kot pa ne.

Nasproten sklep (»Ne bo mu uspelo.«) postane splošno sprejemljiv šele, če ga uvedemo s protivnim veznikom ampak. Na primer:

\section{(2) Janez je delal. Ampak mu ne bo uspelo.}

Ampak uporabljamo zato, da argumentativno pričakovanje in argumentativno usmeritev odvrnemo od tistega, kar se - glede na tisto, kar je bilo povedano pred ampak - zdi samoumevno in pričakovano. $V$ primeru, da nam kdo reče:

\section{(3) Zelo sem zaposlen, ampak to ponudbo bom sprejel.}

bi lahko po prvem delu (»Zelo sem zaposlen«) sklepali na: »Ponudbe ne morem sprejeti.«Prav kakor bi v primeru:

(4) Pavel je inženir, ampak nič prida.

če bi izhajali le iz prvega dela argumentativnega niza (»Pavel je inženir«), najverjetneje sklepali, da se inženir Pavel zna lotiti opravil, za katere je izučen.

Vloga besede ampak v primeru (2‘) je prav opozoriti na drugačen razvoj dogodkov, kot ga ponavadi pričakujemo, če je (ne)kdo delal. Zdaj pa si oglejmo tale dva primera:

${ }^{4}$ Natančna ubeseditev je seveda stvar rekonstrukcije argumenta. Ali z drugimi besedami, nikoli ni in tudi ne more biti »natančna«. 
(5) Janez je malo delal.

in

(5) Marko je malce delal.

Izkušnje kažejo, tako Ducrot, ${ }^{5}$ da obstaja nekakšen konsenz, splošno strinjanje o tem, koliko sta Janez in Marko delala - namreč, bolj malo. Vendar pa bi se večina vprašanih na podlagi obeh izjav verjetno odločila, da je delal Marko več (recimo, dve uri) od Janeza (ki je delal, denimo, le eno uro).

Skoraj nemogoče je objektivno in nesporno ugotoviti, koliko več je delal Marko in kakšna je dejanska razlika med malo in malce. In vendar izjavi (5) in (5) napeljujeta na sklepa, ki sta (argumentativno) nasprotno usmerjena:

(5) Janez je malo delal. $\rightarrow$ Ne bo mu uspelo.

$\left(5^{\prime}\right)$ Marko je malce delal. $\rightarrow$ Uspelo mu bo.

Če izjavi presojamo po informativni plati $-s$ stališča $\gg$ dejstev《 oziroma »dejanskega «stanja stvari v svetu - potem je pomembno predvsem to, da jezik malo in malce predstavlja kot leksema, ki zaznamujeta majhno količino nečesa; med njima je seveda lahko tudi (manjša) kvantitativna razlika, toda še vedno gre za majhno količino nečesa. Če pa se usmerimo na argumentativni vidik presojanja izjav, vidimo, da jezik prislov malo postavi v isto kategorijo kot nič, splob nič, prislov malce pa v isto kategorijo kot veli$k o$. Zakaj? Zato, ker prislov malo očitno argumentira v isto smer kot prislova nič, sploh nič, saj (5) brez težav parafraziramo kot:

(6) Janezsploh ni nić delal. $\rightarrow$ Ne bo mu upelo.

(5’) pa kot (6):

(6) Marko je veliko delal. $\rightarrow$ Uspelo mu bo.

Zdaj pa še malce spremenimo to naše delo - besedo delo, kot jo vidi jezik - in se vprašajmo, v katero smer je lahko usmerjen sledeči argument:

(7) Janez je delal eno uro.

Če ne poznamo konteksta - in ne vemo, koliko časa je potrebno za opravilo, ki se ga je lotil Janez - potem sta možni obe usmeritvi, pozitivna in negativna:

${ }^{5}$ O. Ducrot, Slovenian lectures. Argumentative semantics/Conférences slovènes. Sémantique argumentative (odslej Slovenian lectures ...), Ljubljana 1996. 
(7) Janez je delal eno uro. $\rightarrow$ Uspelo mu bo.

$\rightarrow$ Ne bo mu uspelo.

Če pa smo soočeni z argumentativnim nizom kot:

$\left(7^{\prime}\right)$ Janez je delal eno uro. $\rightarrow$ Ampak mu ne bo uspelo.

nas uporaba veznika ampak takoj, ne glede na kontekst in empirična »dejst$v a \ll$, opozori, da je v normalnem oziroma pričakovanem poteku dogodkov (ena) ura dela dovolj za uspeh v tem konkretnem primeru. Protivni veznik ampak nas tu opozori, da bodisi nimamo opraviti z normalnim potekom dogodkov - da so se razmere spremenile - bodisi moramo upoštevati nov, dodaten kriterij.

Delo pa lahko spremenimo še bolj. Če je bil (7) na neki način nevtralen primer, ki je omogočal dve nasprotni sklepanji, kaj lahko rečemo o primerih (8) in (9)?

(8) Janez je delal samo eno uro.

(9) Janez je delal skoraj eno uro.

Spet govorimo o istem »dejstvu« - uri dela -, jezik pa s prislovoma samo in skoraj to dejstvo predstavi kot (v primeru (8)) nezadostno za dosego uspeha:

(8) Janez je delal samo eno uro. $\rightarrow$ Ne bo mu uspelo.

ali pa kot (v primeru (9)) zadostno za dosego uspeha:

(9) Janez je delal skoraj eno uro. $\rightarrow$ Uspelo mu bo.

Rad bi še enkrat poudaril, da na naša sklepa v primerih (8) in (9) ne vpliva kvantiteta (kolicina) dela, ampak jezik oziroma raba posebnih jezikovnih sredstev. Janez je lahko delal štiri ali osem ur (kar bi ob »normalnem « poteku dogodkov morda utegnilo biti dovolj za delo, ki ga opravlja), toda če bi argument formulirali s pomočjo prislova samo, ki uvaja dejanski čas dela, bi bil sklep lahko le negativen (»Ne bo mu uspelo«) v vseh primerih. Skoraj pa, nasprotno, usmeri zaključke v pozitivno smer, ne glede na »dejstva«. Še več. »Skoraj $\mathrm{X} \ll$ pomeni, če gledamo iz informativne

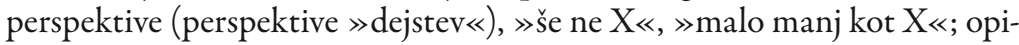
suje torej količino, ki je manjša od »samo $\mathrm{X} \ll$ (ki je pravzaprav preprosto $\mathrm{X}$ ). In vendar ta dejstveno manjša vrednost, »skoraj eno uro«, argumentativno predstavlja več dela kot dejstveno višja vrednost, »samo eno uro «! 
Oglejmo si, kako vplivni so lahko vezniki še na nekaj drugih primerih. Če primerjamo stavka: ${ }^{6}$

(10) Steklenica je že na pol prazna.

(11) Steklenica je še na pol polna.

vidimo, da opisujeta isto stanje stvari, isto objektivno dejstvo - da namreč $\mathrm{v} \gg$ na pol polni $\ll$ ali $\mathrm{v} \gg$ na pol prazni $\ll$ steklenici gladina tekočine sega nekako do polovice. Dejstvi, na kateri se nanašata primera (10) in (11), sta torej pravzaprav enaki, vendar videni iz dveh različnih perspektiv. Kar nam pove, da izjavi (10) in (11) verjetno nista namenjeni poročilu oziroma informiranju o dejanskem stanju količine tekočine v obeh steklenicah, ampak nečemu povsem drugemu. Namreč, primera (10) in (11), kljub temu, da opisujeta isto dejstvo, navajata na povsem nasprotna sklepa:

(10) Steklenica je že na pol prazna. $\rightarrow$ Potrebujemo novo.

(11) Steklenica je še na pol polna. $\rightarrow$ Zaenkrat še ne potrebujemo nove.

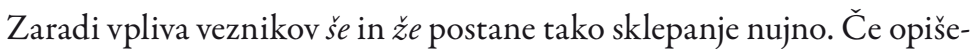
mo steklenico kot »že na pol prazno«, se dejansko pritožujemo nad tem, da bo kmalu povsem prazna. V tem primeru sklepanje, kot $\gg$ Zaenkrat še ne potrebujemo nove«, pač ni najbolj verjetno. Podobno velja tudi takrat, kadar steklenico opisujemo kot $\gg \check{s} e$ na pol polno «, saj tudi v tem primeru verjetno ne želimo argumentirati za sklep »Potrebujemo novo «.

Argumentativni vezniki pa zmorejo še veliko več - lahko kontekstualizirajo primere, ki se na prvi pogled zdijo dekontekstualizirani, in jim pripišejo neki osnovni kontekst. Če je namreč nekaj »že na pol prazno «ali »še na pol polno «, potem lahko povsem upravičeno sklepamo, da gre za opisovanje (takšnega ali drugačnega) procesa praznjenja. Če pa zamenjamo mesti $\check{z} e$ in $\check{s} e$, kot v:

$\left(10^{\circ}\right)$ Steklenica je še na pol prazna.

(11') Steklenica je že na pol polna.

potem očitno opisujemo proces polnjenja. O kakšnem praznjenju ali polnjenju govorimo - kakšne so »umazane podrobnosti « -, je za lingvistično analizo nepomembno; to je ves kontekst, ki ga potrebuje.

Pa to še vedno ni vse, kar zmorejo vezniki; argumente lahko namreč tudi dobesedno strukturirajo in oblikujejo.

${ }^{6}$ Primer smo v nekoliko drugačnem kontekstu (to je aplikacije srednje močnih/šibkih toposov) obravnavali že v sklepni opombi poglavja Argumentacija v jeziku proti argumentaciji zjezikom. 
Denimo, da vam na topel poletni dan nekdo predlaga sprehod. Utrujeni ste, zato mu odgovorite:

(12) Toplo je, ampak sem utrujen.

Vabilo na sprehod ste očitno zavrnili. Če pa bi odgovorili malce drugače, recimo:

(13) Utrujen sem, ampak je toplo.

je dejansko stanje še vedno isto kot v primeru (12) - dan je še vedno topel in vi ste še vedno utrujeni -, vendar je iz vašega odgovora mogoče sklepati, da ste vabilo sprejeli. Vse je pač odvisno od tega, kam postavite besedico ampak (ali kak drugi členek), kateri argument se nahaja pred njo in kateri argument ji sledi. Argumentativno usmeritev sklepa namreć vedno določa tisti argument, ki ampak (ali kakemu drugemu vezniku) sledi, in ne tisti, ki mu predhaja. To pa, povedano z drugimi besedami, pomeni, da imamo (lahko) različne argumentativne usmeritve že znotraj enega samega stavka. $\mathrm{Na}$ kakšen način lahko kaj takega sploh analiziramo?

Na tej točki je Ducrot vpeljal »polifonijo « - koncept, ki si ga je sposodil od Bakhtina - in ga posplošil na jezik kot sistem.

Znano je, da je Bakhtin razlikoval med dialogizmom in polifonijo. V svojem delu Marksizem in filozofija jezika polifonijo opiše kot: »Nekaj izrazito in bistveno ločenega od dialoga. V dialogu besedila vpletenih oseb med seboj niso slovnično povezana, prav tako niso strnjena $\mathrm{v}$ enoten kontekst. ${ }^{7}$ Dialog tako proizvedeta dva govorca ali več, polifonija pa je monološka struktura. Primere za polifone strukture (izjave) je Bakhtin našel predvsem v romanih, v svojem delu o Dostojevskem ${ }^{8}$ pa je zapisal tudi tole (zdaj že slovito) definicijo fenomena polifonije:

»Avtor lahko govorico nekoga drugega prilagodi svojim namenom in to tako, da vanjo vnaša nove namere, izjave pa kljub temu zadržijo svoj referenčni namen. Pod temi pogoji in upoštevajoč avtorjeve namere, moramo $\mathrm{v}$ taki izjavi prepoznati pravega - drugega pošiljatelja. Zato lahko v eni sami izjavi zasledimo dve različni nameri, dva različna glasova.«

Tako po Bakhtinu polifona struktura pripada enemu samemu govor$\mathrm{cu}$, obenem pa vsebuje (oziroma sta v njej pomešani): »Dve različni govo-

${ }^{7}$ M. Bakhtin (pod imenom V. N. Volosinova), Marxism and the philosophy of language, New York 1973, 116.

${ }^{8}$ M. Bakhtin, Problems of Dostoevsky's Poetic, Minneapolis 1984, 180. 
rici, dve izreki, dva sloga, dva jezika, dva semantična in aksiološka sistema verovanj. $\ll^{9}$

Bakhtinov študij polifonije se je naslanjal predvsem na romane, Ducrot pa je ta fenomen posplošil kar na jezik kot sistem. Kako je torej polifonijo opredelil Ducrot?

Ducrot meni, da je to, kar tradicionalna lingvistika poimenuje z govorcem, zelo kompleksna in zmedena predstava, ki pod enim pojmom združuje več povsem različnih idej. Zato predlaga razločevanje med avtorjem, govorcem in izjavljalcem izjave.

Avtor izjave je tisti, katerega aktivnost ima za posledico nastanek izjave; avtor opravi vso nujno intelektualno aktivnost, ki je potrebna za oblikovanje izjave. Čeprav se zdi to na prvi pogled očitno, pa lahko postane v nekaterih primerih dvoumno.

Predstavljajte si na primer sebe v vlogi učenca (primer sem si izposodil od Ducrota). Šola prireja športni dan, vi pa potrebujete, če se ga želite udeležiti, pisno privoljenje svojih staršev. Razrednik vam razdeli obrazce, ki jih morate podpisane prinesti nazaj v šolo. Na obrazcih piše nekaj takega kot: $\gg$ Svojemu sinu/hčerki dovoljujem, da se udeleži športnega dneva, « na dnu pa se nahaja črta, pod katero piše »podpis «. Obrazec prinesete domov, vaš oče ali mama pa se morata podpisati na črto, nad besedo »podpis «. Kdo je tu avtor besedila »Svojemu sinu/hčerki dovoljujem ...«? Vaša mama oziroma oče, ki sta se pod izjavo podpisala? Učitelj, ki vam je obrazec izročil? Tajnica, ki je obrazec natipkala? Ravnatelj, ki ji je izjavo naročil natipkati? Šolsko ministrstvo? Težko je reči. Prav zato moramo ločevati tudi med govorcem in izjavljalcem.

Govorec je tisti, ki je odgovoren za izjavo, ki ga ima za odgovornega izjava sama (je vpisan vanjo), oziroma je odgovoren za dejanje izjavljanja izjave.

$\mathrm{V}$ našem primeru $\mathrm{z}$ učencem in njegovimi starši na prvi pogled nimamo težav - izjava vsebuje morfem 1. osebe ednine sedanjika (-m), ki kot govorca izjave (nedvoumno) določi osebo, podpisano pod izjavo. Kaj pa se zgodi, če izjava ne vsebuje tako transparentnih jezikovnih sredstev? Ali naj bo govorec res odgovoren za vse, kar je rečeno v izjavi? Moramo res vse, kar je izrečeno (ali nakazano) v izjavi, nujno obravnavati kot govorčevo stališče?

$\mathrm{Na}$ tej točki je torej potrebno vpeljati izjavljalce. Po Ducrotu ima namreč vsaka izjava (lahko) več izjavljalcev ali (če smo natančnejši in manj zavajajoči) več različnih izjavljalnih položajev, kar, povedano z drugimi besedami, pomeni, da je lahko v posamezni izjavi zastopanih več različnih stališč.

${ }^{9}$ M. Bakhtin, n. d., 304 . 
Ducrotovo stališče je pravzaprav še bolj radikalno; trdi namreč, da lahko vsako izjavo razčlenimo v najmanj dva izjavljalna položaja. Vzemimo primer negacije:

(14) Ta ograja ni rdeča.

Govorec te izjave predstavlja dva izjavljalca oziroma izjavljalna položaja:

- prvega, (I1), ki trdi, da je ograja rdeča, in

- drugega, (I2), ki zavrača njegovo trditev.

Sam, kot tisti, ki izjavo izreka, se priliči I2.

In vendar - kaj nam omogoča, kaj nam sploh dovoljuje, da postopamo na ta način? Kaj nam daje pravico, da razlikujemo med različnimi izjavljalnimi položaji v okviru iste izjave? V primeru (14), na primer, že samo dejstvo, da ograj, ki bi bile »ne-rdeče «, »ne-rumene« ali »ne-rjave «, sploh ni. Seveda ograjo lahko opišemo kot $\gg$ ne-rdečo «, »ne-rumeno « ali »ne-rjavo«, vendar nam ta podatek ne da prav nobene predstave o tem, kakšne barve ograja v resnici je. Zato nekdo, ki trdi, da »X ni ...«, nujno (četudi implicitno) ugovarja nekemu (četudi neizrečenemu) mnenju, ki trdi nasprotno - da namreč $\gg X$ je ...« (kar seveda ne pomeni, da trdilne izjave ne morejo biti polifone; če nekdo pravi: »Ta ograja je rdeča, « lahko s tem zatrjuje nekaj, kar je nekdo drug zanikal).

Ti argumenti morda zvenijo preveč ontološko, zato se bom raje oprl na primer iz filozofije jezika. ${ }^{10}$ Pred leti ${ }^{11}$ sem skušal analizirati eksplicitne performative s pomočjo polifone analize. Zdelo se mi je, da so izjave kot:

(15) Obljubim.

zelo nenavadne. Če se vam zdi primer sporen, ker da je izvzet iz konteksta, si ga seveda lahko ogledamo še v eni od mogočih »kontekstualiziranih« oblik:

(15') Obljubim, da bom prišel.

Na žalost izjava še vedno zveni zelo nenavadno. Le težko si namreč predstavljam koga, ki bi, kar tako, brez posebnega povoda in razloga, re-

\footnotetext{
${ }^{10} \mathrm{Da}$ bi koncept polifonije lahko čim nazorneje predstavili, si za potrebe pričujoče kritične analize izposojamo tudi primere eksplicitnih performativov (primeri (15)-(19)), ki jih sicer podrobneje obravnavamo v poglavju Kako napravimo kaj z besedami - polifon način.

${ }^{11}$ I. Ž. Žagar, How to do things with words - The polyphonic way, v: I. Ž. Žagar (ur.), Speech acts: Fiction or reality, Ljubljana 1991.
} 
kel (15). Zato lahko spet, in to povsem upravičeno, ugovarjate, da je izjava vzeta iz konteksta in da njen govorec verjetno odgovarja na vprašanje, na primer:

(16) Prideš?

Recimo, da zdaj imamo neki osnovni in neposreden kontekst. Kljub temu pa se mi dialoške povezave, kot je, na primer:

(17) A: Prideš?

B: Obljubim, da bom prišel.

zdijo zelo nenavadne za vsakodnevni pogovor. Kakor da nekaj ne zveni prav: ali nekaj manjka ali pa je nečesa preveč. Kaj želim povedati?

Najbolj običajen, vsakdanji, odgovor na vprašanje (16) bi se verjetno glasil - pod pogojem, seveda, da ostane pritrdilen - ali:

(18) Da.

ali

(19) Pridem.

le težko pa $\left(15^{\circ}\right)$. Če na vprašanje (16) odgovorimo s (15), naš odgovor vsebuje neki presežek glede na zastavljeno vprašanje, presežek, ki opozarja, da nekaj manjka. Primerjajmo dve kratki, simulirani, dialoški navezavi:
I
A: Prideš?
A: Prideš?
B: Pridem.
B: Obljubim, da bom prišel.

V prvem dialogu oseba B osebi A odgovori z jedrnatim, neposrednim odgovorom, v katerem potrdi svoj prihod. $\mathrm{V}$ drugem dialogu pa oseba $\mathrm{B}$ ne odgovori neposredno, ampak svoj prihod obljubi - s performativnim dejanjem obljube se (svečano) obveže, da bo prišla. Kaj to pomeni?

Če si pobliže ogledamo odgovor osebe B v drugem dialogu, vidimo, da sploh ni odgovorila na vprašanje, ki ji ga je zastavila oseba A! Oseba A od nje ni zahtevala obljube, da bo zares prišla, ampak jo je le vprašala, ali pride ali ne. Tako postane očitno, da oseba B v drugem dialogu ni odgovorila na vprašanje, ki ji ga je zastavila oseba $\mathrm{A}$, ampak na vprašanje (ali del poprejšnjega pogovora), ki v danem dialogu sicer ni prisotno, lahko pa nanj sklepamo zaradi rabe performativnega prefiksa. 
Osnovna struktura drugega dialoga bi zato morala biti poliloška, ne le dialoška. Nekako takole:

(17 $)$ A: Jutri imamo zabavo. Prideš?

B: Da.

C: To bi bilo pa prvovrstno presenečenje! Nikoli te ni!

B: Obljubim, da bom prišel.

Različnih stališč izjavljalcev seveda ne moremo prikazovati na način, ki sem ga pravkar uporabil sam - kot pogovor, sestavljen iz »resničnih«izjav, ki naj bi jih (ne)kdo dejansko izrekel. So le rekonstrukcija, rekonstrukcija konteksta. Prav tako ni mogoče stališčem različnih izjavljalcev prisoditi ontološkega statusa, ki bi bil enakovreden izhodiščni izjavi, izjavi, s katero smo analizo začeli, saj so ta stališča le produkt analize in imajo zgolj teoretičen in hipotetičen status. Različna stališca izjavljalcev smemo predstaviti le kot odnose, položaje in usmeritve, na ta način pa primer (17) lahko analiziramo s pomočjo govorca in treh izjavljalcev:

- I1 predstavi dejstvo D (zabava jutri zvečer) in svojo izjavo formulira kot povabilo;

- I2 prepozna predstavitev I1 kot povabilo in ga sprejme;

- I3 podvomi v iskrenost I2 in njegov sprejem povabila prikaže kot dvomljiv; hoda.

- I2' nasprotuje I3 in sprejem povabila dodatno podkrepi z obljubo pri-

Ena Ducrotovih najslovitejših analiz je analiza pragmatične uporabe francoskega prislova $\gg$ toujours $\ll .{ }^{12}$ Recimo, da imamo opraviti s takim argumentativnim nizom:

(20) Allons au bistro. On y sera toujours au chaud.

»Pojdimo v bistro. Tam nam bo vsaj toplo $\ll$.

Po Ducrotu lahko razločimo najmanj pet izjavljalcev:

- I1 predstavi dejstvo D, v našem primeru lastnost L (toploto) objekta $\mathrm{O}$ (bistroja): »V bistroju je toplo «, hkrati pa predstavi to lastnost (toploto) kot prednost objekta $\mathrm{O}$;

- I2 uporabi lastnost L kot argument za sklep S: »Pojdimo v bistro«;

- I3 predstavi lastnost L kot le šibko prednost objekta $O$;

${ }^{12}$ Prim. A. Cadiot, O. Ducrot, T.-B. Nguyen, A. Vicher, Sous un mot, une controverse: Les emplois pragmatiques de 'Toujours', Modèles linguistiques VII (1985), 2, 105-124. 
- I4 to šibkost predstavi kot šibkost, ki dejstvu D odvzame sleherno argumentativno vrednost, posledica tega pa je zavrnitev stališča I2;

- I5, po drugi strani, meni, da je lastnost L, čeprav zgolj šibka prednost, še vedno zadosten argument za sklep $S$ (»Tudi majhna prednost je boljša kot nič«), s čimer zavrne stališče I 4 .

En argumentativni členek, pet izjavljalcev in ključno vprašanje: ali obstaja zgornja meja za število izjavljalcev, ki jih lahko razločimo v posamezni izjavi ali argumentativnem nizu? Ducrotov odgovor je (v principu): ne. Število izjavljalcev je lahko neomejeno. Sam menim, da moramo biti previdni, in da števila izjavljalcev ne smemo povečevati čez mejo, ki jo (še) dopušča analiza. V zgornjem primeru tako ne vidim pravega razloga za ločevanje med I3 in I4. Takšno ločevanje bi bilo lahko le hipotetično, idealno, in ga ni mogoče utemeljiti z razpoložljivimi podatki: raba prislova »toujours « ( $v$ našem primeru $\gg v s a j \ll$ ) nam pove le, da je argument za morebitno odločitev šibak (kar podpira stališče I3), vendar pa ni nobenega pokazatelja, na podlagi katerega bi lahko sklepali, da je argument tako šibak, da izgubi sleherno argumentativno vrednost. Povedano drugače - če želimo polifono analizo jemati resno (in kot smo videli, je lahko zelo uporabno analitično orodje), potem se moramo držati danih empiričnih podatkov, ne pa umišljenih ali zgolj mogočih domnev.

Vrnimo se zdaj še enkrat na primer (12):

(12) Toplo je (argument), ampak sem utrujen (sklep).

s katerim smo odgovorili in zavrnili vabilo na sprehod.

Po Ducrotu imamo tu opraviti z najmanj štirimi izjavljalci: I1 in I2 se nanašata na »Toplo je «, I3 in I4 pa na »Utrujen sem «. I1 z besedami: »Toplo je«, opiše vreme. Ta »Toplo je« - ne pozabite, da je nekdo predlagal sprehod - je predstavljen kot argument, ki govori v korist sprehodu, I1 pa to argumentacijo (lahko) podpre tako, da se opre na topos kot:

(T1) Bolj ko je toplo, prijetneje je iti na sprehod. ${ }^{13}$

Tu se vključi I2, ki, izhajajoč iz stališča I1, (implicitno) argumentacijo zaključi z (implicitnim) sklepom: »Pojdiva na sprehod «. Nasprotuje jima

\footnotetext{
${ }^{13}$ Podrobnejšo predstavitev razmerja med polifonijo in topoi bo zainteresirani bralec (kakor tudi zainteresirana bralka) našel v nadaljevanju kakor tudi v O. Ducrot, Slovenian lectures ..., Ljubljana 1996 in/ali v I. ̌̌. Žagar, From reported speech to polyphony, from Bakhtin to Ducrot, v: M. Javornik (ur.), Bakhtin and the humanities. Proceedings of the International Conference, October 19-21, 1995, Ljubljana 1997.
} 
I3, katerega glas lahko slišimo v tistem delu argumentativnega niza, ki pravi: »Utrujen sem. « I3 svojo argumentacijo (lahko) podpre s toposom, kot:

(T2) Slabše ko se človek počuti, manj prijetno je iti na sprehod.

$S$ tem ko »Utrujen sem « ponudi kot argument proti sprehodu, je počutje predstavljeno kot lastnost, zaradi katere sprehod lahko postane neprijeten. Končno se vključi še I4, ki, izhajajoč iz stališča I3, (implicitno) zavrne vabilo na sprehod.

V članku From reported speech to polyphony, from Bakhtin to Ducrot ${ }^{14}$ sem takšno analizo zavrnil takole: če I2 nekaj sklepa, izhajajoč iz stališča, ki ga zagovarja I1, I4 pa nekaj sklepa, izhajajoč iz stališča, ki ga zagovarja I3, zakaj potem sploh potrebujemo I 2 in I4? I 2 in I 4 bi lahko svoje sklepe oblikovala tudi sama.

Prav takšnemu sklepanju pa se moramo izogniti, če želimo polifono analizo jemati resno. Ducrotovi izjavljalci namreč niso konkretne, fizične osebe, ki bi lahko poslušale druga drugo in v pogovoru oblikovale lastne sklepe; izjavljalci pravzaprav zaznamujejo le različne izjavljalne položaje, različna stališca in perspektive, ki jih labko razločimo $v$ posameznih argumentativnih nizih. Izjavljalci niso živa bitja, ki bi se lahko med sabo pogovarjala. So le teoretične (in analitične) entitete, ki nam pomagajo rekonstruirati argumentativni tok.

Če torej želimo v naši analizi zajeti vsa stališča, ki jih lahko določimo $\mathrm{v}$ posameznem argumentativnem nizu, potem potrebujemo tudi I 2 in I4.

${ }^{14}$ I. Žagar, n. d., 45. 



\section{Topoi: \\ črna skrinjica $\operatorname{argumentacije}^{1}$}

$\gg \mathrm{M}$

oja teza je, da argumentacija, kot je formulirana v govoru, temelji na skalarnih principih. Vse, kar sem rekel, predpostavlja jasno razlikovanje med sklepanjem in argumentacijo, in kot jezikoslovca med zanima, za kaj v govoru gre, in ne, kaj se dogaja v glavah ljudi... $\mathrm{Z}$ vidika logike, se policistu ni treba zanašati na skalarni princip, a ko spregovori, vtisne skalarnost v stvari, ki je le-te same po sebi nimajo. Skalarnost je omejitev, ki nam jo vsiljuje govor /vsi poudarki I. Ž. Ž./.«²

Teza, na katero se nanaša navedek (kakor tudi sam navedek), ni moja, temveč jo zagovarja francoski jezikoslovec Oswald Ducrot (se pa z njo strinjam). Toda preden se posvetimo razliki med tem, kaj se dogaja v govoru in kaj v glavah ljudi, si oglejmo zgodbo policista, ki ga omenja zgornji navedek.

V svojih Slovenskih predavanjih, ki so izšla leta 1996, je Oswald Ducrot branil tezo, da ljudje svoje argumente gradijo na principih (topoi), ki so skalarni in imajo štiri temeljne oblike:

$+\mathrm{Q}+\mathrm{P}$ (Bolj ko smo lačni, več moramo jesti);

-Q-P (Manj ko smo lačni, manj moramo jesti);

$+\mathrm{Q}-\mathrm{P}$ (Bolj ko smo lačni, manj moramo jesti);

$-\mathrm{Q}+\mathrm{P}$ (Manj ko smo lačni, več moramo jesti).

Da bi to lahko utemeljil, si je izmislil sledečo zgodbo:

${ }^{1}$ Prim. poglavje Med argumentativnimi vezniki in polifonijo.

${ }^{2}$ O. Ducrot, Slovenian lectures ..., 162. 
»Predpostavimo, da je bil nekdo umorjen, recimo, tukaj ob pol petih in da so ga zabodli do smrti (to je zelo pomembna podrobnost za moj prikaz). Krivca iščejo in policija sumi nekega francoskega jezikoslovca, ki je trenutno v Ljubljani: ta jezikoslovec je imel razloge za to, da je zameril svoji žrtvi, ki je bila sploh zelo nastrojena proti teoriji argumentacije in še posebej proti skalarnosti; še več, rano bi prav lahko povzročilo bodalo, ki ga ima jezikoslovec običajno med svojo prtljago. $V$ tem trenutku preiskave je do policije prišla nova informacija: da je bil francoski jezikoslovec ob pol petih, v času zločina, v svojem hotelu in očitno ni mogel tukaj nikogar zabosti. Razglašen je bil za nedolžnega na osnovi sledečega argumenta: 'On ne more biti, saj je bil ob pol petih v svojem hotelu.'Zdise, da tak primer kaže na to, da principi, na katerih temeljijo argumenti, niso nujno skalarni. V tem primeru argument temelji na principu, po katerem Kadar osebe ni na nekem kraju, tam ne more ničesar storiti, in zdi se, da pri tem principu ni nič skalarnega /vsi poudarki I. Ž. Ž./. 3 $^{3}$

To je prvi del Ducrotovega argumenta, ki mu običajno ne ugovarjajo. Verjetno zato, ker Ducrot na nek način preoblikuje ali restrukturira argumentativni model Stephena Toulmina, ${ }^{4}$ kjer prehod od argumenta (dejstva v Toulminovi terminologiji) do sklepa (trditve v Toulminovi terminologiji) temelji na toposu (utemeljitvi v Toulminovi terminologiji). Toulminov osnovni model (v treh korakih) je takšen:

(1) Dejstvo $\rightarrow$ Trditev

\section{Utemeljitev}

Da bomo pravični do zgodovine retorike in argumentacije, moramo dodati, da je Toulmin v resnici le rekonstruiral Aristotelov in Kvintilijanov model teorije o entimemu, kjer ena od premis (običajno večja, a ne nujno) - ki ostaja implicitna ali eksplicitno neizrečena, saj jo domnevno delita govoreči in ogovorjeni - utemeljuje prehod od druge premise k sklepu. In če smo povsem pošteni do Toulminovega modela argumentacije, moramo dodati, da je njegov »sestavljeni vzorec « ali »sestavljeni načrt « argumenta ${ }^{5}$ - v šestih korakih - konceptualno zelo soroden izpopolnjenemu epihejre$\mathrm{mu}$, razvitemu in utemeljenemu entimemu, ki naj bi ga vpeljal Aristotelov učenec Teofrast. A temu se bomo podrobneje posvetili nekoliko kasneje.

Nadaljujmo sedaj z Ducrotom. Njegova teza o (topični) skalarnosti je v resnici veliko bolj radikalna in avtor svojo zgodbo nadaljuje takole:

${ }^{3}$ O. Ducrot, n. d., $158-160$.

${ }^{4}$ S. Toulmin, The Uses of Argument, Cambridge 1958/1995, 94-107.

${ }^{5}$ S. Toulmin, n. d., 101-104. 
»Vračamo se k isti situaciji. Torej, policija je pravkar dobila informacijo, da je bil jezikoslovec ob pol petih v svojem hotelu. Tedaj je do policistov nenadoma prišlo še več informacij, po katerih jezikoslovec pravzaprav ni bil v svojem hotelu, temveč še veliko dlje od kraja umora, recimo, da je obiskal grad izven mesta, na podeželju. S tem, ko je rekel, »Ob pol petih je bil v svojem hotelu«, bi policist lahko k temu, kar je pravkar rekel, kot popravek dodal, »Pravzaprav je celo obiskal grad «. Mislim, da bi policist res utegnil uporabiti 'celo', zato da bi popravil prvi del informacije. Spomnite se sedaj mojega opisa 'celo.' Trdim, da 'celo povezuje dva argumenta, ki prehajata k skupnemu sklepu, pri čemer je drugi argument predstavljen kot močnejši od prvega. Tako je 'Bil je na gradu’ močnejši argument za sklep ('Ni kriv') kot 'Bil je v hotelu'. Zakaj je močnejši? Če je močnejši argument, je to zato, ker se topos, ki ga je uporabljal policist, ni glasil, Kadar osebe ni na nekem kraju, tamne moreničesar storiti, temveč raje, Dljeko je oseba oddaljena od nekega kraja, manj možnosti obstaja, da bi tam kaj storila. S tem, ko je bil jezikoslovec v stvarnem času na gradu, je bilo tako še manj možnosti, da bi storil umor, kot če bi bil v hotelu /vsi poudarki I. Ž. Ž./.«

To je ena od Ducrotovih tez, ki je še vedno tarča nenehnih poskusov, da bi jo ovrgli. In to celo bolj kot njegova in Anscombrova teorija o polifoniji v jeziku kot sistemu, ki je končno dobila nekaj veljave (čeprav več med jezikoslovci kot med teoretiki argumentacije). Običajni očitek njegovi predstavitveni tezi o skalarnosti v govoru in na katerega sem moral tudi sam večkrat odgovoriti, je: »To je povsem umetno. Človeški razum nikakor ne sklepa na tak način.« (Proti)-argumentov nasprotniki sicer niso predstavili.

Toda, ali to drži? Je res, da človeški razum ne sklepa na tak način? Oglejmo si nekaj vsakdanjih primerov - tokrat resničnih in ne izmišljenih kot je Ducrotov primer.

\section{I}

Pred nekaj leti smo z družino počitnice preživeli na otoku Visu, ki je zelo lep in odmaknjen otok v Jadranskem morju. Nekega dne je mojemu sinu, ki je bil takrat star štiri leta, spodrsnilo na skali, udaril se je, a ni bilo nič hujšega. Toda moja žena je pripomnila:

\section{(2) Le nekaj centimetrou bolj levo in labko bi bilo usodno!}

Vse, kar je rekla, je bilo povsem hipotetično: sin ni padel nekaj centimetrov bolj levo (kjer je bila v resnici precej nevarna luknja) in sploh ni bilo usodno; toda zanimivo je, da je bil argument moje žene o resnosti sinove-

${ }^{6}$ O. Ducrot, n. d., 160. 
ga padca skalaren. Poskusimo ga rekonstruirati v skladu s Toulminovim (osnovnim) modelom:

(2a) Trditev (Sklep) Otrok je nevarno padel.

$S$ čim lahko to utemeljite?

\section{(2b) Dejstvo (Argument) Ko bipadel le nekajcentimetrov boljnalevo, bibilo to zanj labko usodno.}

Kako ste prišli do tega?

\section{(2c) Utemeljitev (Topos) Bliže ko nekdo pade nevarnemu mestu, hujsij je padec.}

Povzemimo (še enkrat), kaj se je v resnici zgodilo: otrok je padel. Dobil je le manjšo modrico. A ker je bila v bližini nevarna luknja v skali, je bil njegov padec ocenjen kot zelo nevaren in celotna argumentacija je dobila skalarno obliko. Kaj se je dogajalo v glavi moje žene, ko je izrekla (2) (ali nekaj trenutkov pred tem), ne vem in pravzaprav niti ni pomembno: njen argument sem povsem razumel. Seveda bi bilo zanimivo vedeti, kako in na kakšen način oblikuje argumente razum, še posebej, kadar gre za argumente te vrste. A ker so (t. j. kadar so, kar pa ni vedno) oblikovani in predstavljeni kot skalarni, to povsem zadostuje za njihovo razumevanje, oceno in (potencialno) akcijo/re-akcijo (če je potrebna).

\section{II}

Verjetno se boste tudi sami spomnili podobne izmenjave bodisi iz vsakdanjega življenja, medijev ali od kod drugod. To niti ni tako pomembno, pomembno je, da ljudje očitno uporabljajo in razumejo skalarnost kot možno in veljavno obliko argumentacije.

(3) A (pride domov): Kaj je za kosilo?

B: Piščanec.

B: Piščanec??? Lahko bi pojedel vola.

V zadnjem odgovoru je A izrekel povsem hipotetične stvari in brez dvoma se je izrazil metaforično. Čeprav je zelo očitno tudi, da je uporabljal skalarni argument. Če ga analiziramo in rekonstruiramo s pomočjo Toulminovega modela, dobimo sledečo shemo:

(3a) Trditev (Sklep) Zelo sem laćen.

$S$ čim lahko to utemeljite? 
(3b) Dejstvo (Argument) Labko bi pojedel ne le pišcanca, ampak vola.

Kako ste prišli do tega?

(3c) Utemeljitev (Topos) Boljko si lačen, več labko poješ.

A to bi se utegnilo zdeti preveč trivialno (čeprav je argumentacija, ki prežema vse vsakdanje dejavnosti, lahko trivialna).

Oglejmo si dogodek (trivialen), ki se je pripetil na božični večerji pred nekaj leti (dogodek je pravzaprav zelo podoben znamenitemu prizoru iz filma Smisel življenja, ustvarjalcev skupine Monty Python):

\section{III}

(4) A (se baše s hrano): Še en čokoladni piškot, pa bom počil!

Kar je hotel reči, je seveda bilo to, da je več kot sit. Toda jasno je, da je svojo sitost poudarjal na skalaren način: ni bila gosja pašteta, rakovičja juha, ravioli s tartufi, pečenka z belgijskim radičem in jabolčna pita s smetano - ne, bil je majhen (hipotetični) piškot, ki bi bil preveč. Ali, spet na Toulminov način:

(4a) $\operatorname{Trditev}$ (Sklep) Sem (većkot) sit.

$S$ čim lahko to utemeljite?

(4b) Dejstvo (Argument) Ne morem pojesti niti enega piškota već.

Kako ste prišli do tega?

(4c) Utemeljitev (Topos) Večko ješ, manjpotrebuješza to, da si sit.

\section{IV}

In če se vam ti primeri še vedno zdijo nepomembne vsakdanje anekdote, je tu ena, ki bi vas morala prepričati. V Sloveniji poznamo zvrst glasbe - uradno se imenuje »narodno zabavna glasba - ki jo imenujemo tudi »humpa humpa« glasba ali še manj uglajeno, »goveja« glasba. Ko sem se nekoč o tej glasbi pogovarjal s starejšim človekom in izrazil velik odpor do nje, mi je odgovoril:

\section{(5) Potem pa nisi dovolj Slovenec.}

Kot vidite, človek ne more preprosto biti ali ne biti Slovenec; slovenskost se meri v stopnjah: nekdo je lahko tudi bolj ali manj Slovenec, ne gle- 
de na državljanstvo ali potni list, kaj šele sorodstvene vezi (mimogrede: ta zvrst glasbe je celo še bolj popularna v Avstriji in v nekaterih delih Nemčije). Ali, spet na Toulminov način:

\section{(5a) Trditev (Sklep) Nisi dovolj Slovenec.}

$S$ čim lahko to utemeljite?

(5b) Dejstvo (Argument) Ne marašslovenske narodno zabaune glasbe.

Kako ste prišli do tega?

\section{(5c) Utemeljitev (Topos) Bolj ti je věeč slovenska narodno zabauna glasba, bolj si Slovenec.}

Skalarnosti običajno očitajo (očitki večinoma prihajajo od logikov in jezikoslovcev), da topoi (ali utemeljitve) ne bi smeli biti oblikovani v skalarni obliki, temveč raje kavzalno (»Če $\mathrm{P}$ potem $\mathrm{Q} \ll$ ). Toda takšna formulacija ne bi utemeljila sklepa $v$ vseh primerih: človek, $s$ katerim sem se pogovarjal, ni rekel, da nisem Slovenec (mož je vedel, da ne bi mogel utemeljiti takšne trditve), rekel je, da nisem dovolj Slovenec. V skladu z njegovo argumentacijo so ljudje, ki poslušajo govejo glasbo, le bolj Slovenci, kot tisti, ki je ne poslušajo.

Tudi v našem drugem primeru utemeljitev »Če si lačen, moraš jesti« ne bi zadovoljivo pojasnila situacije. Dotična oseba ni le rekla, da je lačna; moški je rekel, da je zelo lačen, tako lačen, da mu zgolj piščanec ne bi zadostoval.

A kot smo že omenili, se Toulmin ni ustavil pri tem preprostem (celo poenostavljenem) modelu v treh korakih, temveč je zasnoval veliko bolj kompleksen model $\mathrm{v}$ šestih korakih. Izhajajoč iz njegovega preprostega modela, bi lahko domnevali, da je utemeljitev absolutno pravilo, ki ne dopušča izjem. Toda takšno pravilo, ki običajno ostaja implicitno, seveda ne more biti univerzalno, kar pomeni, da moramo v modelu narediti prostor za izjeme ('zavrnitev'v Toulminovi opredelitvi), da trditev lahko omilijo sredstva 'kvalifikatorja' in da tudi sama utemeljitev utegne potrebovati kakšno 'oporo'.

In če tako razširjen model sedaj apliciramo na naše skalarne primere, lahko takoj opazimo sledeče: kljub temu da je lahko povsem jasno, kaj nam govori jezik, je veliko manj jasno, kaj se v istem trenutku dogaja v mislih.

Spet si oglejmo naš prvi primer: 


\section{(2) Le nekaj centimetrov bolj levo in lahko bi bilo usodno!}

utemeljen z:

\section{(2c) Bliže ko nekdo pade nevarnemu mestu, hujsije padec.}

Toulminov razširjen model dvomi o tej utemeljitvi in ji zastavlja neprijetno vprašanje: Ali je tako v vseh primerih? Ali je res? Težko rečemo. Odvisno je od tega, kako predelujemo (t. j. naš razum) informacije. In kaj je tisto, kar v vsakem posameznem primeru velja kot informacija. Ali, če smo še bolj eksaktni: kaj je tisto, kar velja kot ključna informacija za interpreta. $\mathrm{Ne}$ bom razglabljal o tem hipotetično mogočem podatku, do katerega nimam prav nobenega dostopa; a kljub temu bi rad nakazal možni caveat. Predpostavimo, da materin (besedni) odziv ne bi bil (2), ampak, recimo, (6a).

\section{(6a) Hvala bogu! Vse je v redu z njim!}

Ali to pomeni, da njen argument ne bi bil skalaren? Ni nujno. Prav mogoče je, celo zelo verjetno, da je izrekla (6a) zgolj zato, ker je videla tisto veliko luknjo, oddaljeno le nekaj centimetrov na levo in ker je spoznala (čeprav tega ni eksplicitno ubesedila), da bi padec nekaj centimetrov bolj levo bil lahko usoden. Celotno argumentacijo bi zato lahko brali kot:

(6a) Trditev (Sklep) Hvala bogu! Vse je v redu z njim!

$S$ čim lahko to utemeljite?

(6b) Dejstvo (Argument) Ce bi padel le nekaj centimetrov bolj na levo, bi to labkobilo usodno.

Kako ste prišli do tega?

(6c) Utemeljitev (Topos) Bliže ko kdo pade nevarnemu mestu, slabse je.

Namesto da bi skušala izpeljati »negativni« sklep kot v (2a) (Otrok je nevarno padel.), je mati argumentirala za $\gg$ pozitivni $\ll$ sklep (Vse je v redu z njim!), ki pravzaprav implicira negativni sklep in ima smisel le, če si predstavljamo, za kako nevaren padec bi lahko šlo, ko bi otrok padel le nekaj centimetrov bolj na levo. Predelovanje informacij je bilo tako morda drugačno, a ubeseditev argumenta(cije) ostaja skalarna.

Če se, upoštevajoč to misel, spet vrnemo $\mathrm{k}$ Toulminovemu modelu, se lahko vprašamo sledeče: če utemeljitev, kot smo jo formulirali v (2c) 'Bliže ko nekdo pade nevarnemu mestu, slabše je', ostaja enaka tudi v (6c), kako bi lahko oblikovali zavrnitev ('Ali to velja za vse primere?')? Zelo težko (ali 
vsaj sam tako mislim). V Toulminovem izvirnem primeru smo imeli opraviti z domnevno trdnimi dejstvi (Harry je britanski državljan, Harry se je rodil na Bermudih) - ni čudno, da je Toulmin obe izjavi poimenoval kot dejstvo in trditev $-v$ našem primeru pa se soočamo $s$ povsem hipotetično (kakor tudi subjektivno videno in ocenjeno) situacijo. Če govorimo racionalno (in objektivno), bi lahko rekli, da je padec na nevarno mesto slaba stvar, padec v bližino nevarnega mesta pa ni slaba stvar, kar bi lahko dopustilo sledečo zavrnitev:

\section{(2, 6d) Ne, a pogosto se tako zdi (ali občuti).V resničnem življenju padec blizu nevarnega mesta ne pomeni nić resnega.}

Takšna zavrnitev, ki jo spremlja vprašanje: 'Potem v svoji trditvi ne morete biti tako neomajni, mar ne?’, bi nas lahko vodila k sledečemu kvalifikatorju:

\section{$(2,6 \mathrm{e})$ Ne, le ponavadise tako zdilobcuuti.}

Toda na tem mestu nastopi zares zapleteno vprašanje, ki nas vodi nazaj k utemeljitvi, in sicer: 'Zakaj mislite, da je padec blizu nevarnega mesta slab zgolj zato, ker je blizu nevarnega mesta?' In tam, kjer bi Toulmin lahko v svojem primeru ponudil trdno, neizpodbitno dejstvo (Utelešeno je v sledeči zakonodaji: ...), je vse, kar lahko rečemo mi, le nekaj takega kot:

\section{(2,6f) Očitno našrazum predeluje dane podatke na način, da se nam tako zdi/da tako ob- cutimo.}

Kaj je ta »tako « in iz česa natanko so sestavljeni ti procesi, pravzaprav ne vemo. Omejuje nas argumentacija, ki jo slišimo, in ne argumentacija, kot se (domnevno) odvija v naših glavah. In argumentacija, ki jo slišimo, se zdi skalarna, $v$ našem primeru še celo več kot to: soočeni smo z enim in istim argumentom $(2 \mathrm{~b}, 6 \mathrm{~b})$, ki dopušča dva (navidezno) nasprotujoča si sklepa (2a, 6a).

Naj vašo pozornost preusmerim še $\mathrm{k}$ drugemu zanimivemu problemu, ki je povezan $\mathrm{z}$ razmerjem med argumenti in sklepi (verjetno pa tudi z razmerjem med argumentacijo in kognicijo). Če si natančneje ogledate naša primera (3) in (4), boste opazili, da je mogoče zamenjati mesto(-i) argumenta in sklepa, ne da bi se pri tem bistveno spremenil pomen:

(3b) Labko bi pojedel ne le pišcanca, ampak vola. (Argument) $\rightarrow$ (3a) Zelo sem lačen. (Sklep),

bi zlahka spremenili/parafrazirali kot: 
(3a) Zelo sem lačen. (Argument) $\rightarrow$ (3b) Labko bipojedel ne le piščanca, ampak
vola. (Sklep).

Ali:

(4b) Ne morem pojesti niti enega piškota več. (Argument) $\rightarrow(4 \mathrm{a}) \operatorname{Sem}($ več kot) sit! (Sklep),

bi prav lahko parafrazirali kot:

(4a) Sem (vec kot) sit! (Argument) $\rightarrow$ (4b) Ne morem pojesti niti enega piškota već. (Sklep).

Edina razlika med obema verzijama je v tem, da bi sklep »izvirne « verzije lahko vzeli/razumeli kot implikaturo (t. j. implicitno, neizgovorjeno) $s$ tem bi »izvirna« verzija postala entimem $\mathrm{z}$ manjkajočo večjo premiso in z manjkajočim sklepom - medtem ko sklepa obrnjene verzije (verjetno) ne bi mogli razumeti kot implikaturo (ker vsebuje takšne posebne elemente, kot so »piščanec«, »vol « in »piškot«, (verjetno) ni dovolj splošna ). Toda vse ostalo, skupaj z utemeljitvijo, bi lahko ostalo nespremenjeno.

Če že govorimo o entimemih, večjih in manjših premisah, sklepih in utemeljitvah, je morda to primerno mesto, da si jih nekoliko podrobneje ogledamo. In $\mathrm{k}$ njim bomo prišli, spet po ovinku, s pomočjo teorije Oswalda Ducrota o argumentaciji v jezikovnem sistemu (TAJ), ki uporablja vse zgoraj omenjene koncepte, a v drugačni razporeditvi in $\mathrm{z}$ drugimi konceptualizacijami.

V prejšnjem poglavju smo že pojasnili izhodiščno tezo TAJ. Če nekoliko povzamemo, bi lahko rekli, da je izhodiščna teza Ducrotove teorije o argumentaciji v jezikovnem sistemu (TAJ), da so posamezne argumentativne prvine vsebovane v jeziku kot sistemu. To pomeni, da jezik kot abstraktna, splošna struktura (kakor ga opredeljuje de Saussure), že sam po sebi poseduje ali vsebuje nek argumentativni potencial, neko argumentativno moč in določene argumentativne usmeritve - ne le jezik v dejanju, njegova raba $\mathrm{v}$ diskurzu in kot diskurz. Denimo, obstajajo določene jezikovne strukture, ki diskurzu (restriktivno) nalagajo določeno argumentativno usmeritev, z drugimi besedami, jezik kot abstrakten sistem (vsaj delno) nadzoruje to, kar lahko pove diskurz, in določa njegove meje. Do podobnih zaključkov, čeprav po drugačni poti in le posredno v zvezi z argumentacijo, prihaja tudi Janja Žmavc v analizi pomenskega polja samostalnika animus pri Terenciju. Avtorica z analizo jezikovnih struktur pri latinskem komediogra-

${ }^{7}$ Prim. poglavje Med argumentativnimi vezniki in polifonijo. 
fu ugotavlja, da je pomenski potencial animus vpisan tudi v okvir strukture latinskega jezika:

»S pomočjo slovnične interpretacije Terencijeve Andrije je torej mogoče dokazati, da zaznamuje samostalnik animus značilnost oziroma sposobnost, ki je lastna zgolj človeku in je določena z njegovim obstojem. Gre za prostorski pojem, za neke vrste »prostor v človeku«, ki sam ničesar ne dela, ampak omogoča nastanek vseh miselnih in čustvenih duševnih procesov, s katerimi je opredeljeno vsako človekovo zavestno ali nezavedno dejanje. $\ll^{8}$

$\mathrm{V}$ poznih sedemdesetih in zgodnjih osemdesetih je Ducrotova teorija argumentacije obravnavala jezikovne členke (kar so nekateri ameriški jezikoslovci skušali dobesedno ponovno odkriti v devetdesetih) kot posrednike ali prenašalce argumentativne usmeritve. $V$ poznih osemdesetih in devetdesetih letih se je Ducrot začel zanimati za topoi. Sam uporablja Aristotelov izraz in meni, da je bolj ali manj zvest njegovi ideji, čeprav obenem priznava, da jo je nekoliko popačil. Oglejmo si podrobneje to »deformacijo $\ll$.

Danes velja skoraj za vsakdanje prepričanje (za poseben topos), da je za Aristotela topos mesto, kjer najdemo argumente, oddelek ali področje, kjer je mogoče zlahka najti veliko retoričnih argumentov, pripravljenih za takojšnjo uporabo - kar je velika zmota. Po Aristotelu naj bi namreč obstajali dve vrsti topoi: splošni ali skupni topoi, primerni, da jih uporabimo povsod in kjerkoli, ne glede na situacijo, in posebni topoi, ki so v svoji uporabnosti omejeni na različne znanosti, področja znanja, strokovnosti, mnenja, razmere itd. Ali, kot pravi Aristotel:

$\gg$ S posebnimi toposi (eide) mislim na propozicije, ki so posebne glede na vsak razred, in s splošnimi (koinoi topoi) tiste, ki so vsem enako skupne.«?

Aristotelski topos ('mesto', 'kraj') je argumentativna shema, ki dialektiku ali retoriku omogoča konstrukcijo argumenta za dani sklep; filozof jih vidi kot (temeljne) sestavine entimemov. Rabo izrazov topoi (koinoi) ali loci communes, kot so jih poznali Rimljani, lahko zasledujemo vse do najzgodnejših retorjev (večinoma jih imenujejo sofisti), kot sta Protagoras in Gorgias. Kot v analizi najstarejšega antičnega priročnika, Anaksimenove Retorike za Aleksandra, ugotavlja Janja $\breve{Z}$ mavc, ${ }^{10}$ so sofistom topoi predstavljali

${ }^{8} \mathrm{~J}$. Žmavc, Terencijev animus: analiza pomenskega polja, Keria 4 (2002), 2, 129.

${ }^{9}$ Rh. 1358a31-32 1.2.22.

${ }^{10} \mathrm{~J}$. Žmavc, Ethos and pathos in Anaximenes' Rhetoric to Alexander: a conflation of rhetorical and argumentative concepts, v: F. H. van Eemeren, D. C. Williams, I. Ž. Žagar (ur.), Understanding argumentation: work in progress, Amsterdam 2008, 168-169. 
argumentativni koncept, ki verjetno ni imel enotne oblike, saj so ga v kontekstu njegove retorične funkcije (t. j. kot sredstvo prepričevanja) retorji poljubno združevali z drugimi retoričnimi strategijami. Toda medtem ko so v zgodnji retoriki topos vsekakor razumeli kot gotov vzorec ali formulo, vnaprej pripravljen argument, ki ga je mogoče uporabiti na določeni stopnji govora (da bi ustvaril določen učinek ali še pomembneje, da bi upravičil določen sklep) - pojmovanje, ki je prevladalo tudi z renesanso - pa velja za večino Aristotelovih topoi, da so to splošna navodila, ki omogočajo izpeljavo sklepa določene oblike (ne vsebine) iz premis določene oblike (ne vsebine). Prav zato smo poudarili, da je velika zmota precej razširjeno prepričanje o tem, kako so Aristotelovi topoi mesta, kjer je mogoče najti vnaprej pripravljene argumente.

Če si ogledamo seznam Aristotelovih topoi koinoi ali skupne topike:

7)

\begin{tabular}{|c|c|}
\hline SPLOŠNE TOPIKE & POSEBNE TOPIKE \\
\hline $\begin{array}{l}\text { Definicija } \\
\text { Rod/vrsta } \\
\text { Razdelitev } \\
\text { Celota/deli } \\
\text { Subjekt/predikati } \\
\text { Primerjava } \\
\text { Podobnost/razlika } \\
\text { Stopnja } \\
\text { Odnos } \\
\text { Vzrok/učinek } \\
\text { Antecedens/konsekvens } \\
\text { Kontrarnosti } \\
\text { Kontradikcije } \\
\text { Okoliščine } \\
\text { Mogoče/nemogoče } \\
\text { Preteklo/prihodnje } \\
\text { Pričevanje } \\
\text { Avtoritete(izvedenci) } \\
\text { Priče } \\
\text { Maksime/rekla } \\
\text { Govorice } \\
\text { Prisege } \\
\text { Dokumenti } \\
\text { Zakoni } \\
\text { Precedensi } \\
\text { Nadnaravno } \\
\text { Notacija in sorodne besede }\end{array}$ & $\begin{array}{l}\text { Sodna (pravne) } \\
\text { pravično (prav) } \\
\text { nepravično (narobe) } \\
\text { Svetovalna } \\
\text { dobro } \\
\text { nevredno } \\
\text { ugodno } \\
\text { neugodno } \\
\text { Hvalna (ceremonialna) } \\
\text { krepost (plemenito) } \\
\text { slabost (nizkotno) }\end{array}$ \\
\hline
\end{tabular}


in jih primerjamo s seznamom njegovih kategorij:

8)

Substanca

Kvantiteta

Kvaliteta

Razmerje

Prostor

Čas

Položaj

Stanje

Delovanje

Utrpevanje

postane precej očitno, da je filozof svoje skupne topike izpeljal iz kategorij: medtem ko kategorije predstavljajo najbolj splošne (in temeljne) odnose med različnimi entitetami v svetu (in so zato po naravi metafizične), predstavljajo skupne topike najbolj splošne (in temeljne) odnose med koncepti, pojmi, ali besedami, ki predstavljajo (označujejo) te različne entitete v svetu. Paradoksalno, Aristotel opisuje topoi kot »prazna mesta «, kjer je mogoče najti izoblikovane argumente za različne namene. In četudi to zveni paradoksalno, je povsem logično: ko ta mesta ne bi bila prazna in ne bi dopuščala za vsako konkretno stvar, da se v njih oblikuje, ampak bi bila že zapolnjena, to ne bi bila več skupna mesta. Razen tega jih ne bi mogli več uporabljati v prav vsaki situaciji, temveč le v tisti, ki bi bila opisana in definirana s stvarno vsebino posameznega toposa.

Kot pravi ena od Aristotelovih opredelitev pojma topos (Rh. 1403a1718 2.26.1): »Element in topos imenujem enako; kajti element ali topos predstavljata področje, kamor spada veliko entimemov.« Pomembno je poudariti, da z izrazom 'element' (stoikheion) Aristotel ne misli na točen del entimema, temveč na splošno obliko, v okviru katere je zajeti mogoče konkretne entimeme istega tipa. Po tej definiciji je topos splošna argumentativna oblika ali vzorec in konkretni argumenti so instanciacije te splošne oblike. Ali, kot pravi Auctor ad Herennium (3-29.15ss.): loci predstavljajo ozadje in konkretni argumenti so imagines na tem ozadju.

Naj le na kratko spomnim. Vsi verjetno poznate kategorični silogizem. In če ne, je tukaj znamenit, skoraj že razglašen primer: 
9)

Vsi ljudje so umrljivi.

Sokrat je človek.

Sokrat je umrljiv.

Kategorični silogizem sestavljata dve premisi, večja ali splošna in manjša ali posebna ter sklep. Obe premisi, kakor tudi sklep morajo biti v kategoričnem silogizmu eksplicitno izraženi.

Prav tako velja: če sta premisi resnični in je sklepalni proces veljaven, mora biti nujno resničen tudi sklep.

Entimem, ki se imenuje tudi »retorični silogizem «, je pogosto označen kot »okrnjeni silogizem«. Zakaj? Zato, ker mu pogosto manjka ena od premis, običajno večja oziroma splošna, kajti njena narava je tako skupna in splošna, da velja za topos, za nekaj tako splošnega in skupnega, da je preprosto niti ni treba omenjati. Entimematična različica zgornjega kategoričnega silogizma bi se tako (lahko) glasila:

10)

Vsi ljudje so umrljivi

Sokrat je umrljiv

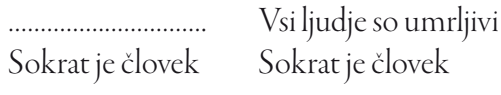

Sokrat je umrljiv

Morda se boste spraševali, ali ni trditev 'Vsi ljudje so umrljivi' prav tako splošna in skupna v kategoričnem, kot je v retoričnem silogizmu. Odgovor je, seveda, pritrdilen. Toda, ker velja kategorični silogizem za orodje znanosti, mora biti vsak korak eksplicitno izražen, medtem ko je retorični silogizem orodje vsakodnevne komunikacije kjer, ne le, da lahko, temveč včasih celo moramo izpustiti očitne stvari, če želimo učinkovito komunicirati.

Z Rimljani so topoi postali loci (kar je velik »napredek « za govorce indo-evropskih jezikov ...) in Ciceron jih dobesedno opredeli kot mesta, kot »bivališče vseh dokazov« (De or. 2.166.2), »skrivališče dokazov« (Part. Or. 5.7-10) ali preprosto »zakladnico argumentov (Part. Or. 109.5-6). Toda pri Kvintilijanu (Inst. 5.10.22ss.) najdemo nekaj »napotkov o rabi«, kako izvleči argumente iz teh mest, namreč s pomočjo znamenite mreže vprašanj: Quis? Quid? Ubi? Quibus auxiliis? Cur? Quomodo? Quando? 
V Novi retoriki ${ }^{11}$ - v tem kratkem pregledu bom izpustil skoraj 2000 let (večinoma) propadanja retorike - topoi niso definirani kot mesta, ki skrivajo argumente, temveč kot zelo splošne premise, ki nam pomagajo graditi vrednote in hierarhije, nekaj, čemur se je Perelman še posebej posvečal. A celo on je pustil topose na do neke mere deskriptivni ravni in se ni poglobil $\mathrm{v}$ tehnologijo njihovega delovanja ali v njihovo arhitekturo.

Presenetljivo je, da je v istem letu, ko sta Perelman in Olbrechts-Tytéca objavila svojo Novo retoriko, Stephen Toulmin objavil delo Uses of Argument, ki je morda ena najbolj podrobnih študij o tem, kako delujejo topoi. »Presenetljivo « pravim zato, ker avtor ne uporablja izraza topos ali topoi, ampak neke vrste sodni izraz »utemeljitev«. Razlog za to se zdi očiten: zajeti skuša različna »področja argumentov«, vsa področja argumentov pa, kot pravi, ne uporabljajo toposov kot argumentativne principe ali kot izho-

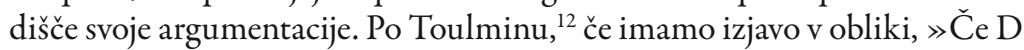
potem T - kjer D predstavlja dejstvo ali dokaz, T pa trditev ali sklep - deluje utemeljitev kot most in omogoča (avtorizira) korak od D do T. Toda, utemeljitev ima lahko omejeno uporabnost, zato Toulmin vpelje kvalifikatorje K, ki kažejo na moč, ki jo daje utemeljitev, in pogoje zavrnitve (Z), ki označujejo okoliščine, $\mathrm{v}$ katerih bi morala biti razveljavljena splošna avtoriteta utemeljitve. In na koncu, če je utemeljitev na kakršen koli način izzvana, potrebujemo tudi oporo $(\mathrm{O})$. Kot pravi Toulmin:

»Izjave utemeljitev [...] so hipotetične, podobne mostu, toda opora za utemeljitev je lahko izražena v obliki kategoričnih dejstvenih izjav. « ${ }^{13}$

Njegov diagram argumentacije lahko ponazorimo takole:

11)

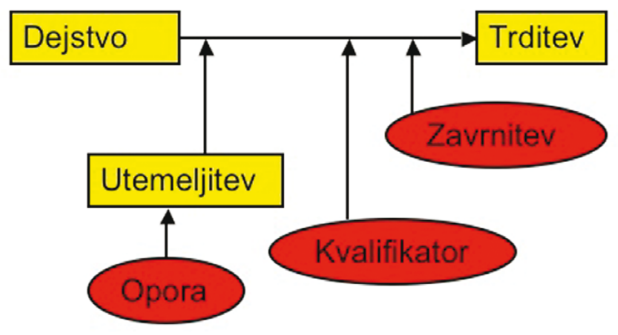

\footnotetext{
${ }^{11}$ Prim. Ch. Perelman, L. Olbrechts-Tyteca, Traité de l'argumentation - La nouvelle rhétorique,Bruxelles 1958/1983, 113.

${ }^{12}$ S. Toulmin, n. d., 94-107.

${ }^{13}$ N. d., 105.
} 
Omeniti velja, da imamo v Toulminovem diagramu opraviti z neke vrste »površinsko « in »globinsko « zgradbo: medtem ko dejstvo in trditev ostajata na površju, kot je to običajno v vsakdanji komunikaciji, je utemeljitev - običajno in zaradi svoje splošnosti - pod površjem, tako kot topos $\mathrm{v}$ entimemih, in prihaja na površje, kadar je vprašljiva njena veljavnost ali verjetnost.

Vrnimo se k Ducrotu in obnovimo nekatera izhodišča iz našega prvega poglavja. Francoski jezikoslovec topos definira kot princip, ki zagotavlja veljavnost ali legitimnost prehoda od izjave A(rgument) do izjave $S$ (klep). Oglejmo si še drugi Ducrotov priljubljen primer (h kateremu se bomo vračali še v nadaljevanju):

\section{(12) Toplo je (A). Pojdiva na sprehod (S).}

Topos naj bi se $\mathrm{v}$ tem primeru nanašal na dve lastnosti: prva lastnost je $\mathrm{P}$ (toplota), ki je povezana $\mathrm{z}$ argumentom (A), druga lastnost pa $\mathrm{Q}$ (prijetnost sprehoda), ki je povezana s sklepom (S). In katere so značilnosti toposa, tega tihega, neizrečenega principa, ki naj bi ga našli v ozadju argumentativnih diskurzivnih segmentov? Ducrot trdi, da ima topos tri značilnosti: prvo, ki je splošna; drugo, ki je predstavljena kot skupno prepričanje, to je prepričanje, ki je skupno določeni skupini ljudi; in tretjo, ki je skalarna. Topos, ki zagotavlja veljavnost prehoda od A do S v (12), bi se lahko glasil:

(13) $\mathrm{T}=$ Bolj ko je toplo, prijetneje se je sprehajati

Rekel sem »bi se lahko glasil«, kajti topoi niso samoobstoječe, neodvisne entitete per se, kot, na primer, Platonove ideje, ampak naj bi bile vedno rekonstruirane iz danega argumentativnega niza.

In kako naj razumemo splošnost toposa? Predvsem tako, da si topos predstavljamo kot zelo splošno strukturo ali matrico, ki omogoča množico posebnih sklepov, ki pa niso obvezni in zavezujoči, kot je, na primer, kategorični silogizem (kar, seveda, pomeni tudi, da topos ni univerzalen). Topos (t. j. sklicevanje na topos ali njegova evokacija oziroma uporaba) lahko omogoči neki sklep, a ne zavezuje nujno k temu sklepu, ali z drugimi besedami: če sprejmemo argument, ni nujno, da sprejmemo tudi sklep. ${ }^{14} \mathrm{Na}$ primer, v odgovoru na (12), ki je povabilo na sprehod, bi prav lahko rekli

(12') Toplo je. Ampak pojdiva namesto tega plavat.

( $\mathrm{T}=$ Bolj ko je toplo, prijetneje se je ohladiti v vodi)

${ }^{14}$ Prim. poglavje Argumentacija v jeziku proti argumentaciji z jezikom. 
ali

(12") Toplo je. Ampak pojdiva raje igrat karte v senco.

( $\mathrm{T}=$ Bolj ko je toplo, prijetneje je biti v senci).

Kar pomeni, da je naš sogovornik v obeh primerih prepoznal veljavnost toposa, ki je bil uporabljen v predlogu za sprehod, ne da bi se s z njim strinjal v tej specifični situaciji. Neki drugi topos se mu/ji je zdel primernejši za to situacijo in uporabil/-a ga je, da je z njim podprl/-a drug sklep namesto tega.

Ko pravimo, da je topos splošen in ne univerzalen, priznavamo tudi njegove morebitne izjeme, kar pa ne ovira njegove veljavnosti, in prav to je bistvo znamenite in Aristotelu pripisane formule: »izjeme omogočajo potrditev pravila $v$ nepredvidenih primerih«; v takih primerih pojem izjeme vseeno omogoča potrditev veljavnosti pravila.

Kako lahko dokažemo splošni značaj toposa? Spet se moramo spomniti na zavrnitve argumenta: slednje namreč zelo pogosto upoštevajo splošnost toposa. Predpostavimo (ponovno), da je toplo in da to dejstvo uporabljam (ponovno) kot argument za predlog o sprehodu. Lahko bi ugovarjali: »Tudi včeraj je bilo toplo, pa je bil sprehod kljub temu neprijeten.« To pomeni, da opozarjate, da obstajajo izjeme pravila, ki sem ga uporabil, in $s$ tem, ko to rečete, predlagate, da morda ne bi smel uporabili tega pravila $\mathrm{v}$ tem posebnem primeru. Toda z opozarjanjem na obstoj izjem priznavate, da pravilo, ki sem ga uporabil, je splošno, in istočasno mi govorite tudi, da morda - po vašem mnenju - nisem bil v položaju, ko bi v tej specifični situaciji lahko uporabil to pravilo. S tem nikakor ne zanikate splošnosti pravila, le kažete mi, da obstajajo njegove izjeme, in predlagate, da bi to lahko bil eden od tistih izjemnih primerov.

Rekli smo tudi, da je topos predstavljen kot skupno prepričanje, ki ga je predhodno sprejela skupnost, kateri pripadata govorec in sogovorec (ali ogovorjeni). Z drugimi besedami, predstavitev toposa kot skupnega prepričanja pomeni, da določena skupnost (bodisi narod ali manjša subkultura) prepoznava njegovo veljavnost, to je veljavnost in upravičenost sklepov, ki temeljijo na njem. Toda, kot smo že lahko videli, to ne pomeni, da bo vsak član skupnosti nujno uporabil iste topoi v identičnih situacijah: uporabo nekega toposa ali sklep, ki ga dopušča ta topos, je vedno mogoče zavrniti z drugim (splošno sprejetim) toposom.

In končno, ko pravimo, da je topos skalaren, govorimo dvoje. Prvič, lastnosti $\mathrm{P}$ in $\mathrm{Q}$ sta sami po sebi skalarni. To pomeni, da sta lastnosti, ki ju lahko imate v večji ali manjši količini. Izjavi $\mathrm{P}$ in $\mathrm{Q}, \mathrm{ki}$ ju povezuje do- 
ločen topos, moramo torej pojmovati kot lestvici. Drugič, obstajajo različne stopnje intenzivnosti, ki jih vsebuje značilnost $P$ in značilnost $Q$. A to sploh ne pomeni, da so tudi sami argumenti in sklepi skalarni. Lastnosti, $\mathrm{ki}$ so uporabljene in omenjene $\mathrm{v}$ okviru toposa so skalarne, toda to ne velja za izjave, ki so uporabljene v diskurzu kot dejanski argumenti ali sklepi; lete že predstavljajo ali uporabljajo kot izhodišče določeno stopnjo (raven) na dveh lestvicah. Oglejmo si sledeči primer (namenoma sem vse primere izbral iz Ducrotove zadnje knjige Slovenska predavanja): $:^{15}$

(14) »Manj kot deset stopinj je. Vzemi plašč s sabo«.

O tem, ali sta A in S skalarna, ni dvoma: ne more biti bolj ali manj deset stopinj; ali je ali ni deset stopinj. Prav tako ne morete bolj ali manj vzeti plašča; ali ga vzamete ali ne. Zatorej navedbe, ki jih vsebujeta $A$ in $S$, niso skalarne. Toda, to ne preprečuje, da ne bi mogli opisati v skalarnem smislu toposa, ki je utemeljitev tega niza. Topos v tem primeru je

(15) T= Bolj ko je mrzlo, topleje se moraš obleči

in povezuje eno lastnost $\mathrm{P}$, ki je hladnost, $\mathrm{z}$ drugo $\mathrm{Q}, \mathrm{ki}$ je, recimo, toplota oblačila. Navedbe, ki jih vsebujejo segmenti diskurza A in S, » Manj kot deset stopinj je«, in, »Vzemi plašč s sabo «, predstavljajo stopnje znotraj teh splošnih lastnosti $\mathrm{P}$ in $\mathrm{Q}$, in prepričan sem, da se boste strinjali, da je lah$k o$ bolj ali manj hladno in da labko oblečemo bolj ali manj topla oblačila.

Obstaja še neka druga ideja o skalarnosti toposa, ki ji Ducrot posveča posebno pozornost. Gre za to, da je samo po sebi skalarno tudi razmerje, ki ga med P in Q ustvarja topos. Videli smo že, da sta P in Q lestvici (lahko je bolj ali manj toplo in lahko se oblečemo bolj ali manj toplo): topos nakazuje, da obstaja skalarno razmerje med stopnjami lastnosti P in stopnjami lastnosti Q. To pomeni, da napredovati v določeni smeri po lestvici lastnosti P pomeni tudi napredovati v določeni smeri po lestvici lastnosti Q: če se premikamo gor ali dol po eni lestvici, se premikamo gor ali dol tudi po drugi.

Za trenutek se vrnimo k primeru (14). Predpostavimo, da ni manj kot deset stopinj, ampak, recimo, okoli dvajset stopinj. V takšnih razmerah človek ne bi rekel, »Manj kot deset stopinj je. Vzemi plašč!«, temveč raje, »Okoli dvajset stopinj je. Ne vzemi plašča «, pri čemer bi uporabljen topos ostal enak, morda le v drugačni obliki. Kar pa nas pripelje še do nove ide-

${ }^{15}$ O. Ducrot, n. d. 
je: do ločevanja med toposom in topično obliko, ki je tesno povezano s pojmom skalarnosti.

Vzemimo še enkrat v skalarnem smislu topos, ki povezuje lastnost $\mathrm{P}$ in lastnost Q. Videli smo že, da ko se premikamo po lestvici P v neki smeri, se v neki smeri premikamo tudi po lestvici Q: ko se vzpenjamo po $P$, se vzpenjamo po Q. Ni težko opaziti, da izjava: »Bolj ko se vzpenjaš po P, bolj se vzpenjaš po $\mathrm{Q} \ll$, deluje enako kot izjava: »Bolj ko se spuščaš po $\mathrm{P}$, bolj se spuščaš po $\mathrm{Q} \ll$. Če velja, da bolj ko se vzpenjaš po toplotni lestvici, bolj se vzpenjaš po lestvici prijetnosti, mora veljati tudi, da bolj ko se spuščaš po toplotni lestvici, bolj se spuščaš po lestvici prijetnosti. Topos, ki na skalaren način povezuje toploto $(\mathrm{P})$ in prijetnost $(\mathrm{Q})$, ima zatorej lahko dve obliki in Ducrot ju simbolično prikazuje kot

$$
\begin{array}{r}
+\mathrm{P},+\mathrm{Q} \\
-\mathrm{P},-\mathrm{Q}
\end{array}
$$

To sta dve topični obliki, TO“ in TO“, ki pripadata istemu toposu T. Isto razmerje med toploto in prijetnostjo je mogoče obravnavati v dveh oblikah, »pozitivno « v prvem primeru in $\gg$ negativno $\ll \mathrm{v}$ drugem. In to še ni vse. Oglejte si sledeče topične oblike (kjer P zaznamuje toploto in $\mathrm{Q}$ prijetnost):

$$
\text { (17) } \begin{array}{r}
+\mathrm{P}-\mathrm{Q} \\
-\mathrm{P}+\mathrm{Q}
\end{array}
$$

Ti dve obliki bi se glasili, »Bolj ko je toplo, manj prijetno se je sprehajati $\ll$, in $\gg$ Manj ko je toplo, prijetneje se je sprehajati.« Priznati moramo, da $\mathrm{v}$ različnih časovnih obdobjih in $\mathrm{v}$ različnih življenjskih situacijah (pogosto je razmeroma težko reči natanko kdaj in zakaj) uporabljamo oba para topičnih oblik, (16) in (17): prvega, po katerem je prijetno, kadar je toplo, in drugega, po katerem ni prijetno, kadar je toplo.

Sprva je Ducrot uporabljal topose le v smislu utemeljitev (s Toulminovimi besedami), ki omogočajo/dovoljujejo prehod od izjave-argumenta do izjave-sklepa. Če si, recimo, spet ogledamo primer (14), bi se topos, ki dovoljuje prehod od A do S, (lahko) glasil takole: »Bolj ko je mrzlo, topleje se moraš obleči.« Težava je bila v tem, da je bilo topose treba rekonstruirati iz danega argumentativnega niza (kar je pogosto pri utemeljitvah) in da so bili zaradi tega videti kot arbitrarni. Toda nato je Ducrot opazil, da so oziroma so lahko (t. j. toposi) še več kot to: da jih je mogoče interpretirati kot fragmente diskurza, ki so vsebovani (zapisani) v (vsaj nekaterih) bese- 
dah jezikovnega sistema. Oglejmo si tele štiri pridevnike (tudi te sem si izposodil pri Ducrotu):

\section{(18) pogumen, boječ, preudaren, nepremišljen}

Kot nativni govorci boste brez težav opazili, da ti štirje pridevniki na neki način sodijo v eno kategorijo in opisujejo iste vrste vedenja (natančneje, dve med sabo povezani vrsti vedenja), a jih vidimo na različne načine. Ducrot bi rekel, da imamo v jezikovnem sistemu kot takem dva toposa, T1 in T2, ki sta primerna za vsako situacijo (kot smo že lahko spoznali pri primeru toplote in prijetnosti): $\mathrm{v}$ zgornjem primeru (18), topos T1 pripisuje vrednost spopadanju z nevarnostjo, tveganju, in to počne z medsebojnim povezovanjem pojma tveganja in pojma dobrega. Nasprotno, topos T2 povezuje pojem tveganja s pojmom zla (slabega). Tako je v prvem primeru tveganje opredeljeno kot nekaj dobrega, v drugem kot nekaj slabega in ob različnih priložnostih ter $\mathrm{v}$ odvisnosti od lastnih diskurzivnih intenc, predstavljamo tveganje kot dejanje, ki ga je vredno storiti in smo razumevajoči do tistega, ki tvega, drugič pa nasprotno predstavljamo tveganje kot nekaj slabega.

Ni težko videti, kako bi bilo mogoče klasificirati te štiri pridevnike: dva med njimi dopolnjujeta topos T1, druga dva topos T2. Katera dva? Pogumen dopolnjuje topos T1: ko nekdo za nekoga reče, da je pogumen, mu pripisuje neko pozitivno vrednost in to zato, ker si ta upa tvegati. Pridevnik pogumen zaznamuje pozitivno vrednotenje tveganja. $\mathrm{V}$ primeru pridevnika boječ je uporabljeni topos še vedno topos T1, ki tveganje opredeljuje pozitivno, toda kadar pravimo nekomu, da je boječ, mu pripisujemo neko negativno vrednost. To negativno vrednost pa mu pripisujemo zato, ker si ne upa tvegati, kar implicira, da je tveganje dobro, vsaj v določenih okoliščinah. Pogumen in boječ torej temeljita na istem toposu T1, toda pogumen se uporablja za hvalo tistih, ki si drznejo tvegati, boječ pa za grajo tistih, ki tega ne zmorejo storiti.

Kaj pa druga dva pridevnika: preudaren in nepremišljen? Oba udejanjata isti topos T2, topos, ki ne odobrava tveganja. Kadar nekomu rečemo, da je premišljen, tej osebi, razen če ne gre za ironično rabo, pripisujemo določeno kakovost in jo hvalimo, ker se zna izogniti tveganju: $\mathrm{v}$ tem smislu primeru pojmujemo tveganje kot slabo. V primeru pridevnika nepremišljen gre spet za uporabo istega toposa T2. A s tem, ko nekoga opišemo kot nepremišljenega, to osebo obtožujemo zaradi tveganja na nesprejemljiv in neupravičen način. 
Nadaljujemo lahko z ločevanjem med pogumnim in boječim na eni strani ter preudarnim in nepremišljenim na drugi strani tako, da znotraj vsake od obeh skupin opredelimo pododdelke. Le-te lahko pridobimo tako, da vpeljemo topične oblike. V okviru toposa T1 obstajata dve topični obliki: $\mathrm{TO}_{1}$ ' in $\mathrm{TO}_{1}^{\text {" }}$; in podobno v okviru toposa $\mathrm{T} 2$ : $\mathrm{TO}_{2}$ ' in $\mathrm{TO}_{2}$ ". $\mathrm{TO}_{1}$ ' bi lahko formulirali takole: »Bolj ko nekdo tvega $(+\mathrm{T})$, večjo veljavo ima $(+\mathrm{V}) \ll$, medtem ko bi bila $\mathrm{TO}_{1}$ “ nasprotje prve topične oblike, to je »Manj ko nekdo tvega $(-T)$, manjšo veljavo ima $(-V) \ll$. Sedaj ko smo opredelili ti dve obliki, lahko opredelimo tudi pridevnika pogumen in boječ, ki se oba nanašata na topos T1. Rekli bomo, da pogumen izpolnjuje topično obliko $\mathrm{TO}_{1}$;, »Bolj ko nekdo tvega, večjo veljavo ima«, in boječ topično obliko $\mathrm{TO}_{1}$ “, »Manj ko nekdo tvega, manjšo veljavo ima«.

Enako lahko storimo z dvema pridevnikoma, povezanima s toposom T2, ki ne odobrava tveganja: $\mathrm{TO}_{2}{ }^{\prime}$ (»Večje ko je tveganje, večje je zlo«) in na drugi strani $\mathrm{TO}_{2}$ “( $\gg$ Manjše ko je tveganje, manjše je zlo «) sta izpolnjeni z dvema pridevnikoma, nepremišljen in preudaren.

Po Ducrotu bi tako dobili sledečo shemo:

T1

$+\mathrm{P},+\mathrm{Q}$ (več tveganja, več dobrega) pogumen

$-\mathrm{P},-\mathrm{Q}$ (manj tveganja, manj dobrega) bojeć

$\mathrm{T} 2$

$+\mathrm{P},+\mathrm{Q}$ (več tveganja, več zla) nepremišljen

-P, -Q (manj tveganja, manj zla) preudaren

Toda T2 lahko predstavimo še na drug, boljši, še bolj aristotelski način, namreč:

$\mathrm{T} 2$

$+\mathrm{P},-\mathrm{Q}$ (več tveganja, manj dobrega) nepremišljen

$-\mathrm{P},+\mathrm{Q}$ (manj tveganja, več dobrega) preudaren

In zakaj naj bi bil ta način predstavitve topičnih oblik boljši? Zlasti zaradi dveh razlogov: prvi je metodološki in drugi epistemološki. Naj pojasnim svojo misel z uporabo še druge skupine pridevnikov (ne bom ponavljal, da sem si tudi te sposodil pri Ducrotu): radodaren, skop, varčen, razsipen. Po Ducrotu bi dobili sledečo shemo: 
(21)

Tl (Već denarja razdaš, bolje je)

$+\mathrm{P}$, +Q (Več denarja, več dobrega) radodaren

-P,-Q(Manj denarja, manj dobrega) skop

T2 (Već denarja razdaś, slabše je)

$+\mathrm{P},+\mathrm{Q}$ (Več denarja, več zla) razsipen

-P,-Q (Manj denarja, manj zla) varčen

Toda, če T2 preoblikujemo kot

$\mathrm{T} 2$

+P,-Q (Več denarja, manj dobrega) razsipen

-P,+Q (Manj denarja, več dobrega) varčen

je to primerneje, ker tak topos

- (metodološko) uporablja iste predikate in isti opis za iste spremenljivke (»dobro« za Q) kot T1 (s katerim se primerja);

- (epistemološko) omogoča, da oblikujemo različne topične oblike ne le glede na to, kako opisujejo, ampak tudi kaj opisujejo.

Če se sedaj vrnemo k prvim štirim pridevnikom, dobimo:

(23)

$+\mathrm{P},+\mathrm{Q}$ (več tveganja, več dobrega) pogumen

+P,-Q (več tveganja, manj dobrega) nepremišljen

za opredelitev tveganja, in

$-\mathrm{P},-\mathrm{Q}$ (manj tveganja, manj dobrega) boječ

$-\mathrm{P},+\mathrm{Q}$ (manj tveganja, več dobrega) preudaren

za opredelitev izogibanja tveganju.

In zakaj je to pomembno? Ker nam omogoča spoznanje, da obstajajo iste »izvenjezikovne« entitete (»stvari v svetu«), ki jih jezik vidi kot popolna nasprotja. Celo do te mere, da je (t. j. jezik) skoval različne pare izrazov za njihovo poimenovanje/označevanje: pogumen in nepremišljen za tveganje ter boječ in preudaren za izogibanje tveganju.

Očitno je, da so pogumen, nepremišljen, boječ in preudaren kompleksni ali sestavljeni predikati (ali, če se izrazimo skromneje, pridevniki), ki so sestavljeni iz dveh elementov: 1) iz opisa neke izvenjezikovne entitete (ponovno bi se rad izognil izrazu »dejstvo«, ker nisem povsem prepričan, kaj 
dejstvo je); 2) iz ovrednotenja tega opisa. Težko bi, na primer, rekli isto za »dobro« ali »slabo«; pravzaprav mislim, da bi ju lahko opisali kot gradnika takšnih kompleksnih predikatov, ki smo jih opisali zgoraj, namreč, kot ocenjevalna/vrednostna gradnika.

Toda tako (kompleksen) opis sproža pomembno vprašanje: ali gre res za iste izvenjezikovne entitete, ki jih jezik vidi drugače? Kadar rečemo nekomu, da je pogumen, ali ne rečemo s tem, da tvega in da $m i$ to odobravamo, medtem ko na drugi strani nekoga označimo kot nepremišljenega, kadar želimo povedati, da ta oseba tvega in da $m i$ tega ne odobravamo? In, na drugi strani: ali ne rečemo, da je nekdo preudaren, če želimo s tem povedati, da se ta oseba tveganju izogiba in da mi to odobravamo, medtem ko nekoga označimo kot boječega, kadar želimo s tem povedati, da se ta oseba izogiba celo razumnemu in upravičenemu tveganju in da mu mi to očitamo? Če to drži, ali so te»izvenjezikovne« entitete zares iste? In če so res izvenjezikovne (t.j. neodvisne od jezika), kako lahko sploh rečemo, da so iste?

$S$ tem se vračamo k naši začetni dihotomiji med argumentacijo kot nečim, kar se razvija v diskurzu, in argumentacijo kot nečim, kar se odvija v naših glavah. Omenili in analizirali smo že Ducrotov primer (12) o toploti kot o dobrem argumentu za sprehod. Po tem ekskurzu (in zaradi njega) lahko z njim nadaljujemo. Točka, kjer smo končali, je bila, da je nekdo predlagal sprehod, rekoč:

(12) Toplo je (Argument). Pojdiva na sprehod! (Sklep).

$\mathrm{Na}$ (12) bi lahko odgovoril z (12“"):

(12“') Toplo je, ampak sem utrujen.

Takšen odgovor lahko brez dvoma razumemo kot zavrnitev: v prvem delu argumenta sem se strinjal, da je toplo, s čimer sem se strinjal s svojim sogovorcem, da je toplo vreme dober (sprejemljiv, zadosten, ...) argument za predlog o sprehodu. Toda v drugem delu argumenta sem trdil, da sem utrujen, kar je bilo predstavljeno (razumljeno in sprejeto) kot močnejši argument, ki je razveljavil prvega in s tem zavrnil ponudbo o sprehodu. Toda, zakaj je drugi argument dajal vtis, kot da je močnejši: ker utrujenost nasploh velja za močnejši argument kot toplota, kadar gre za sprehajanje? Ali pa bi morda na to lahko vplival sam vrstni red argumentov?

Izvedimo poskus in zamenjajmo vrstni red argumentov v odgovoru (12“"), tako da dobimo:

(12“') Utrujen sem, ampak je toplo. (kot odgovor na predlog o sprehodu) 
Naša zavrnitev se je brez dvoma spremenila v sprejetje. Toda pri tej zamenjavi argumentov je zanimivo zlasti to, da je vse (kar zadeva »objektivno realnost « ali »dejstva «) ostalo povsem enako kot v zavrnitvi: vreme je še zmeraj toplo in jaz sem še zmeraj utrujen. Toda v prvem primeru sem ponudbo zavrnil, v drugem pa sem jo sprejel. Zakaj in v čem je razlika? Ali je mogoče, da sem drugače predelal informacijo, preden sem jo vtisnil v diskurz? Ali je morda moj sogovorec predelal drugače to, kar sem v dveh primerih vtisnil v diskurz? Ne bi mogel vedeti. Vse, kar vem (ali vsaj mislim, da vem), je to, da je veznik 'ampak' moral igrati pomembno vlogo v moji argumentaciji (kot je bila ubesedena in jo je slišal moj sogovorec). Najverjetneje je bil 'ampak' kot zaznamovalec nasprotja (in nasprotovanja) tisti, ki je obrnil argumentativno usmeritev celotnega argumentativnega niza od zavrnitve (v (12““)) k sprejetju ( $\left(12^{\text {““” })) . ~ Z ~ d r u g i m i ~ b e s e d a m i: ~ u s m e r i t e v, ~ k i ~}\right.$ je vsebovana v vezniku 'ampak' ali ki je »zapisana vanj«, če hočete, mora biti takšna, da obrne ali razveljavi argumentativno usmeritev predhodnega argumenta, ne ozirajoč se na kontekst. Ali, povedano drugače: če imamo opraviti s sestavljenim argumentom (ki ga sestavlja več argumentov), bo sklep, ne glede na kontekst, zmeraj izhajal iz dela diskurza, ki sledi 'ampak', in ne iz tistega, ki se nahaja pred njim. Zatorej lahko iz argumenta:

\section{(12“") Toplo je, ampak sem utrujen.}

(ki je izrečen kot odgovor nekomu, ki je predlagal sprehod, češ da je toplo), sklepamo le v smeri 'Ne pojdiva na sprehod' (argument 'Utrujen sem', ki je utemeljen s 'Če smo utrujeni, se ni prijetno sprehajati (skalarnost v tem primeru ni potrebna!), razveljavlja argument 'Toplo je', ki ga utemeljuje 'Če je toplo, se je prijetno sprehajati'). Medtem ko iz argumenta:

\section{(12“') Utrujen sem, ampak je toplo.}

lahko sklepamo le v smeri 'Pojdiva na sprehod' (argument 'Toplo je', ki je utemeljen s 'Če je toplo, se je prijetno sprehajati', razveljavlja argument 'Utrujen sem', ki ga utemeljuje 'Če smo utrujeni, se ni prijetno sprehajati') in ne obratno. Zakaj in kako je to mogoče? Moj poskusni odgovor bi bil dvojen:

1) Argumentacijo vedno najdemo v blokih (nizih), sestavljenih iz argumenta (vsaj enega) in sklepa, ki jih moramo vedno obravnavati skupaj, v medsebojnem odnosu in ne $\mathrm{v}$ osamitvi. Kot smo spoznali iz našega začetnega primera (1), argument ne more imeti absolutne in neodvisne usmeritve: le-ta je vedno omejena, pojasnjena in (ponovno) podana s sklepom. Prav tako ima lahko isti argument (vsaj?) dva različna, celo nasprotna skle- 
pa (ali je/ostaja zaradi tega v resnici »isti argument «, je (kot smo opazili prej) tema za drug prispevek). Zatorej moramo, kadar določamo in vrednotimo argument, to početi zmeraj ozirajoč se na doseženi sklep, v okviru dane topike in nikoli v osamitvi.

2) To spet postavlja drugo zanimivo vprašanje: ali jezik obvladuje naše zaznavanje ali je zaznavanje tisto, ki obvladuje jezik? Če namreč tako imenovana izvenjezikovna realnost (t. j. luknja v skali, padec, ...) ostaja enaka, kako je mogoče, da isti argument, ki to realnost opisuje, vodi k dvema nasprotnima sklepoma? Moj tipajoči odgovor bi bil, da ta »izvenjezikovna realnost « ni nikoli dana »kot taka«, kot je - ali naj bi bila - per se (če sploh kaj obstaja per se), ampak vedno kot že posredovana, predstavljena, ali celo ustvarjena $\mathrm{z}$ jezikom. To »izvenjezikovno realnost « lahko razumemo le skozi jezik in je, tako kot je predstavljena v jeziku (kar, seveda, razveljavlja njen »izvenjezikovni« položaj), ne razumemo na neki morda neznan in nerazumljiv način ter jo šele nato prevedemo v jezik. In ker realnost je (v) jeziku in jezik je realnost, lahko manipuliramo z realnostjo, tako kot manipuliramo z jezikom. Vendar ostaja težava $\mathrm{v}$ tem, ali pri manipulaciji z realnostjo kot jezikom dosežemo vse, kar realnost obsega? In še, ali obstaja kak dvom o tem (in moral bi obstajati vsaj z metodološkega in epistemološkega vidika), ali zares vemo, kaj ves čas počnemo? Morda vemo, kaj počnemo, ko manipuliramo z jezikom (čeprav večji del naših jezikovnih izbir poteka nezavedno), toda ali zares vemo, kakšni so učinki te manipulacije v realnosti in na realnosti (kot obstoja onstran jezika)?

To je star kantovski (ali celo predkantovski) problem, katerega rešitev še vedno ni prinesla splošnega soglasja. 


\section{Ali je kontekst res pomemben?}

P red nekaj leti sem imel študenta, katerega odgovor na vsako mojo trditev je bil: »No, to je pa odvisno od konteksta«. Razumeli boste, da sem se sčasoma naveličal tega »argumenta«, zato bom v tem članku poskusil pokazati, da je vloga konteksta $\mathrm{v}$ lingvistični (in argumentativni) analizi pogosto precenjena, da izjave ustvarjajo lasten (osnovni) kontekst in da njihov »realni«, »materialni « in »dejanski« kontekst komaj kaj vpliva na razlago in razumevanje teh izjav.

Oseba, ki je kriva za nastanek tega spolzkega koncepta, je Bronislav Malinowski. V svojem delu iz leta 1923, The problem of meaning in primitive languages, namreč prav moteče trdi tole:

$\gg$ Natanko tako kot v realnosti govorjenih in pisanih jezikov, je beseda brez jezikornega konteksta zgolj izmišljija, ki sama po sebi ne pomeni nič, zato v realnosti govorjenega živega jezika izjava nima nobenega pomena, razen v kontekstu situacije.«

Od te nesrečne izjave dalje se je pojem konteksta le še širil, zaobjemajoč vedno večje število vsebin, in končno dosegel obseg nekakšne množice, ki načeloma vsebuje prav vse in zunaj sebe ne pušča ničesar.

Sam koncept konteksta ponavadi delimo na »lokalne « in »globalne « strukture konteksta: lokalne strukture pokrivajo »kontekst, ki ga ima izjava glede na trenutno situacijo «, globalne pa »globalnejši kontekst kulture ${ }^{2}{ }^{2}$

${ }^{1}$ Različica članka z istim naslovom je bila objavljena v reviji Časopis za kritiko znanosti 27 (1999), 197, 211-220.

${ }^{2}$ T. A. Van Dijk (ur.), Discourse as Structure and Process, London 1997, 19. 
Lokalne strukture konteksta bi tako obsegale: »postavitve (čas, prostor, okoliščine), udeležence in njihove različne komunikacijske in družbene vloge (govorec, predsedujoči, prijatelj itd.), namere, cilje ali namene «, medtem ko bi globalne strukture vsebovale $\gg$ diskurz kot konstitutivni element organizacijskih ali institucionalnih dejanj in postopkov (zakonodaja, sodne razprave, poučevanje, novinarsko poročanje itd.) in situacije, v katerih so sodelujoči vključeni v interakcijo kot člani družbenih kategorij, skupin ali institucij« (prav tam).

Pojem konteksta torej, tako se vsaj zdi:

»ni tako premočrten kot bi utegnile nakazovati njegove zdravorazumske rabe v vsakdanjem življenju. Intuitivno se zdi, da implicira neke vrste okolje ali okoliščine dogodka, dejanja ali diskurza - nekaj, kar moramo vedeti, da bi lahko pravilno razumeli dogodek, dejanje ali razpravo, nekaj, kar deluje kot ozadje, postavitev, okolje, pogoji ali posledice. $\ll^{3}$

V skladu z zgornjo definicijo Van Dijk definira kontekst kot »strukturo tistih lastnosti družbene situacije, ki so sistematično (in ne naključno) pomembne za diskurz «. ${ }^{4}$

In kaj bi utegnilo biti pomembno za diskurz?

»Spol, starost, razred, izobrazba, družbeni položaj, etnična in poklicna pripadnost udeležencev so pogosto pomembni... Po drugi strani pa so višina, teža, barva oči ali posedovanje vozniškega dovoljenja pomembni le redko ali celo nikoli. Enako velja tudi za družbene vloge: nekatere od teh vlog in družbenih odnosov so pogosto pomembne - biti prijatelj al sovražnik, močan ali nemočen, dominanten ali dominiran - medtem ko se za druge zdi, da imajo manj sistematičen vpliv na tekst in govor ter njuno razumevanje, recimo: biti prvi ali zadnji, ljubitelj kina ali gledališča. $\ll^{5}$

Vendar pa bujen razrast mogočih sestavin konteksta (npr. kaj spada zraven in kaj ne) ni edini problem, ki ga imamo s kontekstom. Konteksti namreč niso nekaj določenega ali vnaprej danega: so ali vsaj lahko so fleksibilni in spreminjajoči se, kot taki pa so podvrženi pogajanju. Poleg tega pa:

»konteksti niso objektivni na način, da bi bili sestavljeni iz družbenih dejstev, ki jih vsi udeleženci razumejo na isti način in jih imajo za relevantne. So interpretirani ali konstruirani, udeleženci pa strateško in nenehoma ustvarjajo njihovo pomembnost ${ }^{6}$

${ }^{3}$ T. A. Van Dijk (ur.), Discourse as Social Interaction, London 1997, 11.

${ }^{4} \mathrm{~N} . \mathrm{m}$.

${ }^{5} \mathrm{~N} . \mathrm{m}$.

${ }^{6} \mathrm{~N} . \mathrm{m}$. 
Jef Verschueren ${ }^{7}$ se z Van Dijkom strinja, da:

»kljub navidezno neomejenemu razponu mogočih pomembnih kontekstualnih objektov prilagodljivosti, 'kontekst' ni nedoločen pojem. Resnično pragmatičen pristop h govornemu obnašanju, družbene variabilnosti ne postavlja na nivo idealiziranih skupin, temveč v razpon prepletenih dimenzij, ki prispevajo k družbenim identitetam sogovornikov. 'Kulturne’ dimenzije vključujejo razlikovanje med oralnimi in pismenimi družbami, ruralnimi in urbanimi življenjskimi vzorci ali prevladujočim kulturnim nasproti subkulturnemu okolju. Druge družbene dimenzije spremenljivosti, s katerimi je jezikovna izbira v odnosu medsebojne prilagodljivosti, vsebujejo družbeni razred, etnično, rasno, nacionalno in versko pripadnost, starost, stopnjo izobrazbe, poklic, sorodstvena razmerja, spol, spolno usmerjenost itd. $\ll^{8}$

Vendar pa to, dokler govorimo o kontekstu, še ni vse, ker za nekatere jezike velja, da je:

»koncept 'družbenih povezav' morda potrebno razširiti - da bi razložili določene lingvistične izbire - na zveze, ne le med ljudmi, ampak tudi med ljudmi in živalmi, ljudmi in rastlinami, pa tudi med ljudmi in stvarmi, do stopnje, ko 'interakcija z določenimi živalmi, rastlinami ali stvarmi postane bistven del človekovih (vsako)dnevnih dejavnosti.«?

Kljub temu dolgemu, skoraj neskončnemu spisku, kaj vse spada - in kaj vse bi lahko spadalo - v koncept konteksta, Verschueren trdi, da je uvajanje konteksta v lingvistično analizo predpogoj za natančnost. Zakaj?

»konteksti nastajajo z uporabo jezika, zato so na različne načine omejeni. Čeprav lahko načeloma vsak mogoči sestavni del govornega dogodka pokaže kontekstualno pomemben element, ki ga moramo upoštevati, vsi ti sestavni deli niso ustrezno uporabljeni ob usaki priložnosti. Povedano z drugimi besedami - iz skoraj neskončnega razpona različnih možnosti, kontekste ustvarja dinamika interakcije med izjavljalci in interpreti. ${ }^{10}$

$\mathrm{Z}$ drugimi besedami - izjavljalec in interpret bi v dani situaciji najbrž vedela, kakšen je kontekst in za kaj gre. Precej banalen sklep. Van Dijk se zdi formalnejši in bolj omejujoč kot Verschueren:

${ }^{7}$ Omejujem se le na novejšo pragmatično literaturo.

${ }^{8} \mathrm{~J}$. Verschueren, Understanding Pragmatics, manuscript, 1998, 16.

${ }^{9} \mathrm{~J}$. Verschueren, n. d., 17.

${ }^{10}$ N. d., 139. 
»/S/trukture diskurza se spreminjajo kot funkcija struktur konteksta, zato jih lahko istočasno razložimo v smislu teh kontekstnih struktur. In nasprotno, kontekste same lahko oblikujemo in spreminjamo kot funkcije struktur diskurza. ${ }^{11}$

Francoski lingvist Oswald Ducrot gre v tem pogledu še dlje. Njegova, v tej knjigi že nekajkrat omenjena teza je, da so v jezik kot sistem že vpisane določene argumentativne lastnosti in da lahko jezik na nekaterih nivojih argumentira sam po sebi, sčimer naši dialoški in interaktivni argumentaciji vsili določene omejitve.

Za pričujočo razpravo so ti vidiki TAJ pomembni zlasti zato, ker v povezavi s kontekstom nakazujejo, da izjave ustvarjajo lasten (osnovni) kontekst, in da lahko ta osnovni kontekst (osnoven v smislu 'zadosten za razumevanje in razlago') 'deduciramo' (če smem malce zlorabiti ta koncept) iz teh izjav.

Naj zgornje trditve podkrepim z nekaj primeri (skoraj vse sem namenoma vzel iz različnih Ducrotovih besedil). Recimo, da nam kdo reče (to je primer, ki ga Ducrot uporablja že dvajset let, v različnih fazah razvoja svoje teorije; prav zato ga večkrat, a v različnih kontekstih (!), uporabljam tudi sam):

\section{(1) Ura je osem.}

Če sodimo po primeru (1), se zdi kontekst očiten: ura je osem in (1) nas obvešča o tem dejstvu. Zakaj smo želeli vedeti, koliko je ura, ali zakaj smo želeli, da bi nas kdo opomnil, ko bo ura osem, nima nobene zveze z razumevanjem lokalnega, kaj šele globalnega konteksta: če bi jo imelo, bi se nujno izgubili v kontekstu (posameznega) človeškega uma, v verigah naših namenov in misli. Sledenje našim namenom in mislim pa bi nujno privedlo do izgube vseh konceptualno pomembnih informacij.

Vzemimo pa, da nismo želeli vedeti, koliko je ura, nekdo pa nam je kljub temu postregel z (1). Zakaj bi želel kdorkoli storiti kaj takega? Kakšni bi utegnili biti njegovi motivi. Oseba, ki nam je rekla (1), je želela s to izjavo najverjetneje povedati nekaj povsem drugega. Ampak kaj? Na kakšna (diskurzivna) nadaljevanja lahko izjava (1) napeljuje? Kaj lahko iz nje sklepamo? Ker (še?) ne poznamo okoliščin, v katerih je bila izrečena, lahko sklepamo na precej različnih možnosti:

${ }^{11}$ T. A. Van Dijk (ur.), Discourse as Social Interaction, London 1997, 12. 
(1) Ura je osem. $\rightarrow$ a) Pohiti!

$\rightarrow$ b) Vzemi si čas!

$\rightarrow$ c) Prižgi radio!

$\rightarrow$ č) Pojdi si umit zobe!

$\rightarrow$ d) Iti moram!

Kaj nam povedo ti mogoči argumentativni nizi?

a) da mora nekdo pohiteti (vsaj v trenutku izjavljanja (1), mogoče vsakič, ko je ura osem), ko ura odbije osmo; implicitno to lahko pomeni, da se je on ali ona nekoliko »obiral/a «;

b) da se lahko, ker je ura osem, nekdo oddahne (vsaj v trenutku izjavljanja (1), mogoče vsakič, ko je ura osem); implicitno to lahko pomeni, da se je on ali ona obnašal/a, kot da se mu/ji mudi;

c) da je treba v nekem prostoru P ob osmih prižgati radio (vsaj v trenutku izjavljanja (1), mogoče vsakič, ko je ura osem);

č) da si mora nekdo umiti zobe (najkasneje) ob osmih; (vsaj v trenutku izjavljanja (1), mogoče vsakič, ko je ura osem);

d) da moram oditi (najkasneje) ob osmih (vsaj v trenutku izjavljanja (1), mogoče vsakič, ko je ura osem).

Tu se ukvarjamo s celimi argumentativnimi nizi, z izjavo-argumentom in izjavo-sklepom, ne le z (mogočim) vprašanjem in odgovorom. Nam ti argumentativni nizi povedo kaj o svojem neposrednem kontekstu, ali moramo vedeti, zakaj mora oseba v primeru a) pohiteti, zakaj si lahko oseba v primeru b) vzame čas, zakaj mora oseba v primeru c) prižgati radio, zakaj si mora oseba v primeru č) umiti zobe in zakaj mora oseba v primeru d) nekam oditi?

Ne verjamem, da moramo poznati vse te (osebne) podrobnosti, da bi lahko razumeli, opisali ali interpretirati izjavo. Vzemimo primer a): oseba iz primera a) mora morda hiteti zato, ker bo v nasprotnem primeru zamudila letalo. Če zamudi letalo, ne bo doma pravočasno. Če ne bo pravočasno doma, lahko zamudi rojstni dan svoje hčerke. Če zamudi hčerkin rojstni dan, bo le-ta žalostna. Če bo žalostna, bo jokala. Če bo jokala ...

Skratka, če argumentativnih nizov ne razumemo kot nečesa, kar nam nudi tudi zadostne opise svojih neposrednih kontekstov - zadostnih v smislu, da o kontekstu ne potrebujemo dodatnih informacij, da bi lahko razumeli in interpretirali dani argumentativni niz - izgubimo sleher- 
ni koncept konteksta kot nečesa, kar je mogoče (nedvoumno) definirati in opisati ter se izgubimo v (osebnem) nizu predstav o tem, kaj je in kaj bi lahko bilo, nizu, ki se nikoli ne konča.

Zdaj pa v izjavo (1) vpletimo prislova že in šele, kot v:

(1') Ura je že osem.

in

(1") Ura je šle osem.

Primer smo podrobno analizirali že v poglavju o argumentativnih veznikih in polifoniji ter pokazali, da ob enakih okoliščinah primer $\left(1^{\prime}\right)$ lahko zaključimo le s sklepom: »Pohiti!«, medtem kot iz (1“) lahko sklepamo le na: »Vzemi si čas! «. Čeprav se (1), $\left(1^{\prime}\right)$ in $\left(1^{\prime \prime}\right)$ nanašajo na popolnoma isto kronološko dejstvo - namreč, da je ura osem -, (1) lahko napeljuje na povsem različne sklepe, $\left(1^{\prime}\right)$ dovoljuje le sklepe, ki so usmerjeni v smeri poznosti, (1") pa le sklepe, ki so usmerjeni v smeri zgodnosti.

Takšna različna argumentativna usmerjenost je kljub istemu kronooškemu dejstvu, na katerega se nanašajo (1), (1') in (1“), in istemu stanju stvari mogoča prav zaradi naših različnih gledišč: $\mathrm{v}$ primeru $\left(1^{\prime}\right)$ osmo uro vidimo (in predstavljamo) kot pozno, v primeru (1") pa kot zgodnjo. Razlikovanje v okviru istega stanja stvari lahko torej povzroči že vpeljava dveh jezikovno-argumentativnih operatorjev. V primeru ( $\left.1^{c}\right)$, že naš sklep usmerja v smer »poznosti«, medtem ko nas v primeru ( 1 “") šele navaja na sklep o »zgodnosti« (ne glede na to, o katerem delu dneva v obeh primerih v nadaljevanju govorimo). Dejanski čas je tako nepomemben, kar z drugimi besedami povedano pomeni, da mora biti argumentativna usmeritev v poznost ali zgodnost na neki način že vpisana $v$ obe leksikalni enoti jezikovnega sistema. ${ }^{12}$

Vendar se zdi, da proti tem trditvam govori določen kontekstualni protiargument (namreč, proti vpisanosti argumentativne usmeritve $\mathrm{v}$ določene leksikalne enote jezikovnega sistema). Recimo, da nekdo reče:

$\left(1^{\prime \prime \prime}\right)$ Ura je ŽE osem. $\rightarrow$ Vzemi si čas!

in/ali

$\left(1^{\prime \prime \prime)}\right.$ Ura je šeLE osem. $\rightarrow$ Pohiti!

Pri čemer sta obe izjavi-argumenta izgovorjeni z bolj ali manj izrazitim poudarkom na obeh obravnavanih jezikovno-argumentativnih operatorjih (zato velike črke!), sledita pa jima izjavi-sklepa, ki sta diametralno na-

${ }^{12}$ Podrobnejša analiza je predstavljena v poglavju Med argumentativnimi vezniki in polifonijo. 
sprotni od izjav sklepov v primerih $\left(1^{\circ}\right)$ in $\left(1^{\prime \prime}\right)$. Protiargument se glasi takole: če bi bilo res, da je argumentativna usmerjenost že vpisana v določene leksikalne enote jezikovnega sistema, in če bi bilo res, da izjave same določajo svoj osnovni kontekst, potem argumentativna niza (1“"') in (1“"') ne bi bila mogoča. In vendar sta: če je bilo v primeru (1“") pomembno, da se nekaj postori do osme ure in je zdaj ura (že) osem, potem lahko povsem upravičeno povlečemo sklep (mogoče malce ironično): 'Vzemi si čas', saj je bila priložnost zamujena in ima oseba, ki jo je zamudila, zdaj na razpolago ves

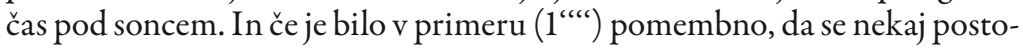
ri nekaj po osmi uri in je zdaj ura (že) osem, lahko povsem upravičeno potegnemo sklep 'Pohiti', če nočemo, da naš sogovornik zamudi tisto, kar naj bi se zgodilo nekaj po osmi uri.

Res, ta dva argumentativna niza ((1““) in (1““”)) sta mogoča; kar ločuje $\left(1^{\prime}\right)$ in $\left(1^{\prime \prime}\right)$ na eni strani in $\left(1^{\prime \prime \prime}\right)$ in (1“"') na drugi je Weltanschauung, ki stoji za njima: glede na $\left(1^{\prime}\right)$ in $\left(1^{\prime \prime}\right)$ se je vredno potruditi (da nekaj naredimo, dosežemo), čeprav se zdi prepozno. Glede na (1““) in (1““”) pa je prepozno (pa čeprav le za trenutek) pač prepozno. Biti moramo točni, ali pa opustiti vse skupaj.

Vendar pa si oba argumentativna niza, četudi ju ločuje Weltanschauung, očitno delita isto epistemologijo glede usmerjenosti prislova že v poznost in usmerjenosti prislova šele v zgodnost: če namreč prislov že ne bi bil usmerjen $\mathrm{v}$ poznost, ga ne bi bilo mogoče uporabiti v argumentativnem nizu, ki nakazuje (argumentira, dokazuje), da je (nekaj) prepozno, namreč (1““) in, mutatis mutandis, če prislov šele ne bi bil usmerjen v zgodnost, ga ne bi bilo mogoče uporabiti v argumentativnem nizu, ki nakazuje (argumentira, dokazuje), da je (nekaj) še zgodaj, namreč (1““‘). Iz česar nedvoumno sledi, da mora biti argumentativna usmerjenost $\mathrm{v}$ poznost nekako vpisana že $\mathrm{v}$ sam prislov $\check{z} e$ argumentativna usmerjenost v zgodnost pa v prislov $\check{s} e l e$.

Oglejmo si nekaj že obravnavanih primerov, ki lepo ilustrirajo omejeno vrednost zunaj-jezikovnega konteksta: ${ }^{13}$

(2) Janez je delal.

V eni od analiz smo ponudili interpretacijo, da je verjetnejša možnost, da izjava napeljuje na sklep + (»Uspelo mu bo.«). Toda izjavo (2) bi seveda lahko »razvili« tudi v argumentativni niz kot:

$\left(2^{\prime}\right)$ Janez je delal. $\rightarrow$ Pravi junak je! ${ }^{13}$ Analizo primerov (2)-(8) si deloma izposojamo iz poglavja Med argumentativnimi vezniki in
polifonijo. 
kar lahko zveni kot protiargument temu, kar sem pravkar zapisal. Vendar ni! Argumentativni niz (2') ima namreč v grobem dve interpretaciji: dobesedno in ironično.

Dobesedna interpretacija implicira, da so pri Janezovem delu nastopile nekakšne ovire: mogoče je invalid, mogoče je (bil) bolan, mogoče je bilo dela, ki ga je moral opraviti, preveč za eno samo osebo, mogoče ...; še mnogo drugih možnosti je. Kar pa nam ( $\left.2^{\prime}\right)$ dejansko pove o vseh teh možnostih je, da je Janez te ovire premagal, da je delal - in da bo pri svojem delu najverjetneje uspešen.

Ironična interpretacija implicira, da ni bilo nikakršne fizične ovire, ki bi motila Janezovo delo, ampak mu to delo, tako ali drugače, ni bilo pretirano všeč in/ali pa ni delal prav pogosto. Vendar pa nam (2') prav tako pove, da je premagal tudi to oviro, da je delal - in da utegne biti pri svojem delu najverjetneje uspešen.

Nasproten sklep (»Ne bo mu uspelo《) kot ena od možnosti izjave »Janez je delal« postane splošno sprejemljiv šele, če ga uvedemo z besedico ampak (ali kakim drugim protivnim veznikom). Na primer:

(2") Janez je delal. Ampak mu ne bo uspelo.

Kot smo že večkrat povedali, ampak argumentativno pričakovanje in argumentativno usmeritev odvrne od tega, kar se - glede na tisto, kar je bilo povedano pred ampak - zdi samoumevno in pričakovano. Tako bi v primeru:

(3) Zelo sem zaposlen, ampak to ponudbo bom sprejel.

iz argumenta $\gg$ Zelo sem zaposlen « lahko sklepali, da bo sklep tekel v smeri: »Imam preveč dela, da bi sprejel še to ponudbo.«

Zdaj pa si oglejmo še primera (4):

(4) Janez je malo delal. in $\left(4^{\prime}\right)$ :

(4') Marko je malce delal.

Po Ducrotu kažejo izkušnje na to, da obstaja nekakšen konsenz, splošno strinjanje o tem, koliko sta Janez in Marko (tako kot sta predstavljena $\mathrm{v}$ primerih $(4)$ in $\left(4^{\circ}\right)$ ) delala - namreč, bolj malo. Govorci, ki jim je slovenščina materni jezik, bi se na podlagi izjav (4) in (4') najverjetneje strin- 
jali tudi o tem, da je delal Marko več (recimo - dve uri) od Janeza (ki je delal, denimo, le eno uro).

Skoraj nemogoče pa je objektivno in nesporno ugotoviti, koliko več je delal Marko in koliko manj je malo od malce. In vendar primera (4) in (4') napeljujeta na (argumentativno) nasprotno usmerjena zaključka:

(4) Janez je malo delal. $\rightarrow$ Ne bo mu uspelo.

(4) Marko je malce delal. $\rightarrow$ Uspelo mu bo.

Če niza (4) in $\left(4^{\circ}\right)$ presojamo po informativni plati - s stališča »dejstev« oziroma dejanskega stanja stvari v svetu - potem je pomembno predvsem to, da jezik malo in malce predstavlja kot jezikovni sredstvi, ki zaznamujeta majhno količino nečesa: čeprav je med njima lahko tudi manjša kvantitativna razlika, oba še vedno označujeta majhno količino nečesa. Če pa niza (4) in (4') presojamo z argumentativnega stališča vidimo, da jezik prislov malo postavi na isto argumentativno lestvico kot nič, splob nič, prislov malce pa na isto argumentativno lestvico kot veliko: prislov malo lahko namreč parafraziramo ali poudarimo (okrepimo) z nič, sploh nič:

(5) Janez je malo delal, celo sploh nič. $\rightarrow$ Ne bo mu uspelo.

malce pa z veliko:

(5) Marko je malce delal, celo veliko. $\rightarrow$ Uspelo mu bo.

Toda, če skušamo opredeliti smer, v katero bi utegnil argumentirati argument:

(6) Janez je delal eno uro.

ugotovimo, da sta v primeru, ko ne poznamo konkretnih okoliščin - ne vemo, koliko časa je potrebno za opravilo, ki se ga je lotil Janez - mogoča oba sklepa, pozitivni in negativni:

(6) Janez je delal eno uro. $\rightarrow$ Uspelo mu bo. $\rightarrow$ Nebo mu uspelo.

Povsem drugače, kot če smo soočeni zargumentativnim nizom, denimo:

(6) Janez je delal eno uro. $\rightarrow$ Ampak mu ne bo uspelo,

kjer nas uporaba jezikovno-argumentativnega operatorja ampak takoj, ne glede na konkretne okolišcine in empirične podatke, opozori, da je ob normalnem oziroma pričakovanem poteku dogodkov (ena) ura dela dovolj za 
uspeh v tem konkretnem primeru. Protivni veznik ampak nam da vedeti, da nimamo opraviti $\mathrm{z} \gg$ normalnim potekom $\operatorname{dogodkov} \ll$, ampak so se razmere (nekako) spremenile oziroma moramo upoštevati nov, dodaten kriterij. To pa je povsem zadosten kontekst za interpretacijo in razumevanje $\left(6^{\circ}\right)$.

Nadaljujmo z našo igro in še nekoliko spremenimo »delo«. Če je bil (6) na neki način nevtralen primer, ki je omogočal dve nasprotni sklepanji, kaj lahko potem rečemo o primerih (7) in (8):

(7) Janez je delal samo eno uro.

(8) Janez je delal skoraj eno uro.

To, da spet (oziroma še vedno) govorimo o istem »dejstvu« - eni uri dela -, jezik pa z jezikovno-argumentativnima operatorjema samo in skoraj to dejstvo predstavi kot (v primeru (7)) nezadostno za dosego uspeha:

(7) Janez je delal samo eno uro. $\rightarrow$ Ne bo mu uspelo.

ali pa (v primeru (8)) zadostno za dosego uspeha:

(8) Janez je delal skoraj eno uro. $\rightarrow$ Uspelo mu bo.

$\mathrm{Na}$ naše sklepe v primerih (7) in (8) tako ne vpliva količina dela, ampak način, kako jezik, spomočjo rabe posebnih jezikounih sredstev, to količino predstavlja. Ali povedano še bolj nedvoumno: Janez bi lahko delal štiri ali osem ur (kar bi utegnilo biti, ob »normalnem poteku dogodkov«, dovolj za delo, ki ga opravlja), toda če bi argument formulirali s pomočjo prislova samo, ki uvaja dejanski čas dela, bi bil sklep v vseh primerih lahko le negativen ( $\gg \mathrm{Ne}$ bo mu uspelo $\ll)$. Tudi če prislov samo interpretiramo ironično, kot $\mathrm{v}$ :

(9) Janez je delal SAMO osem ur.

ko pretirano poudarimo prislov samo, ker želimo izpostaviti kontrast glede na kvantiteto, ki jo prislov vpeljuje, lahko z našo strategijo uspemo predvsem zato, ker jezik prislov samo vidi kot prislov, ki vpeljuje (in opisuje) majhne količine.

Prislov skoraj pa, nasprotno, usmerja sklepe v pozitivno smer, ne glede na 'dejstva'. Še več. »Skoraj $\mathrm{X}$ « pomeni, če ga gledamo iz informativne perspektive (perspektive dejstev), »še ne $\mathrm{X}_{\ll,}$, malo manj kot $\mathrm{X}_{\ll}$, kar je manj tudi od $\gg$ samo $\mathrm{X}_{\ll,}$ ( ki je preprosto le $\mathrm{X}$ ). In vendar to, dejstveno manjšo, 
količino, »skoraj eno uro«, jezik predstavlja kot več dela od dejstveno večje količine, »samo eno uro «.

To pa je odličen primer za prikaz, da ima 'materialni', 'dejanski', 'objektivni' in 'zunaj-jezikovni' kontekst le omejeno vrednost. Če moramo ubesediti nekatera zunaj-jezikovna dejstva - to pa je seveda potrebno, ker jih sicer ne moremo uporabljati kot argumente - je jezik tisti, ki določa, kaj je kontekst in kako se obnaša, ne pa zunaj-jezikovne okoliščine. 

rednost filozofov je, da se lahko čudijo, Platon celo pravi, »da je čudenje edini izvor filozofije $\ll .^{2}$

Kot filozof bom torej izkoristil ta privilegirani položaj in se ponovno (za)čudil - performativnosti. Morda se res lahko zdi čudno, da se 35 let po njenem »odkritju « in obilici objavljene literature performativnosti še vedno čudim, toda tisto, kar je res čudno, je dejstvo, da se - četudi so performativni fenomeni vedno vzbujali (za)čudenje - teoretiki performativnosti niso nikoli uspeli sporazumeti o temeljnih mehanizmih, ki proizvajajo performativne učinke.

Čudil se bom torej, da teorija govornih dejanj - vsaj v obstoječih različicah - , po eni strani tako fragmentarna, torej nepopolna, po drugi pa tako toga, torej težko uporabljiva, lahko nastopa kot interpretativni model nečesa tako dinamičnega, kot je dialog ali konverzacija.

Sam bom predlagal nasprotno rešitev, namreč dialoško - ali še bolje, poliloško - interpretacijo performativnosti, interpretacijo, ki jo bom - po Ducrotu - imenoval polifono.

I

Izjava

(1) Obljubljam.

${ }^{1}$ Nekoliko drugačna različica članka je bila objavljena pod naslovom Performativnost kot polifonija v reviji Anthropos 24 (1992), 5/6, 125-134.

${ }^{2}$ Tht. 155d3-4. 
se mi zdi na primer na moč čudna. Že, že, boste rekli, toda v tej obliki je iztrgana iz ko(n)teksta (kakršna koli že je njegova/njuna definicija): kadar obljubljamo, vedno obljubljamo kaj določenega. Naj bo. Vzemimo torej izjavo (1) v njeni »razviti« obliki, na primer:

(1') Obljubljam, da pridem.

Na žalost se mi tudi ta izjava ne zdi nič manj čudna. Si lahko predstavljate koga, ki pravi, kar tako, nenadoma:

(1') Obljubljam, da pridem.

Težko. Toda ponovno mi boste ugovarjali, da sem izjavo iztrgal iz ko(n) teksta in da govorec bržčas odgovarja na kako vprašanje, na primer:

(2) Ali prideš?

Naj bo. Vendar tudi ta(kšna) dialoška navezava ne deluje preveč prepričevalno:

(3) A: Ali prideš?

B: Obljubljam, da pridem.

Morda v kaki starogrški tragediji, ne pa vsakdanjem govoru. Nekaj je narobe: nekaj bodisi manjka ali pa je nečesa preveč. Kaj hočem reči?

Najbolj običajen odgovor na vprašanje (2) je brez dvoma (če seveda ostajamo v »pozitivnem « registru) bodisi

(4) Da./Ja.

bodisi

(3) Pridem

Če odgovorimo z (1 $\left.1^{`}\right)$ je, glede na vprašanje, v našem odgovoru nečesa preveč, nečesa, kar kaže na neki manko.

Primerjajmo tile dve dialoški navezavi:

I

A: Aliprideš?

B: Pridem.
II

A: Ali pridešs?

B: Obljubljam, da pridem.

Kaj ju ločuje? V čem je razlika med njima? V prvi različici B preprosto odgovarja na A-jevo vprašanje in $s$ tem potrjuje svoj prihod. $V$ drugi raz- 
ličici pa B ne odgovarja več »preprosto « na A-jevo vprašanje, temveč se, $s$ tem, ko izvrši dejanje obljube, svečano obveže, da bo prišel. Kaj to pomeni?

Če si pobliže ogledamo B-jev odgovor, v drugi različici opazimo, da $B$ sploh ne odgovarja na A-jevo vprašanje: A od njega namreč ni zahteval, naj mu obljubi, da bo prišel, temveč le, naj mu pove, ali bo prišel ali ne. Ne, nikakor ne gre za to, da bi bil preveč dlakocepski, skušam le slediti Austinu, ki v delu Sense and Sensibilia vztraja na leibnizovski maksimi, ki pravi nekako takole: če v vsakdanjem jeziku obstajajo razlike, četudi še tako neznatne, potem mora biti za to nedvomno dober razlog.

In če je tako, potem je očitno, da v drugi različici B odgovarja na neko drugo vprašanje, na neki drugi konverzacijski poseg, ki je sicer odsoten iz danega/obravnavanega konverzacijskega drobca, toda interpretativno predpostavljen prav s prisotnostjo - z dejanjem izjavljanja - performativnega obrazca.

»Globinska struktura« - če si lahko izposodim ta izraz iz nekega drugega konceptualnega polja - druge različice dialoga bi morala biti torej poliloška in ne le dialoška, nekako takšna:

(3") A: Jutri zvečer imamo zabavo. Ali prideš?

B: Pridem.

C: To bi bilo pa res presenečenje! Ponavadi nikoli ne prideš!

B: Obljubljam, da pridem.

Vendar pa glagolu 'obljubiti' pogosto pripisujejo nekako poseben status, ki naj bi sklepom, ki jih je iz primerov, v katerih nastopa, mogoče potegniti, jemal zanesljivost in splošno veljavnost. Poskusimo torej še z drugimi glagoli, na primer 'ukazati' in 'prositi'.

Vsekakor še vedno ostajam na moč začuden nad izjavama kot

(5) Ukazujem ti, da zapustiš sobo.

ali

(6) Prosim te, da zapreš vrata.

vzetima, seveda, izven ko(n)teksta.

Takšni izjavi ponavadi predpostavljata vsaj še eno, predhodno in (ponavadi) slabo razumljeno izjavo, katere pojasnilo hočeta biti.

Na primer: 
(5) A: Zapusti sobo!

B: Prosim?

A: Ukazujem ti, da zapustiš sobo!

ali

(6') A: Ali lahko zapreš vrata?

B: Kaj?

A: Prosim te, da zapreš vrata!

Opazili boste, da je uporabljeni postopek na moč podoben postopku, ki ga je predlagal Austin, da bi rešil svojo prvo teorijo performativnosti, preden jo je razpustil v mnogo splošnejši teoriji govornih dejanj. Naj ga še enkrat citiram:

»Vendar pa nikakor ni nujno, da bi biti morala neka izjava zato, da bi imela performativni učinek, izražena v eni od tistih oblik, ki veljajo za normalne. Reči,

'Zaprite vrata, je, to se vidi, prav tako performativ, prav tako izvršitev nekega dejanja, kakor reči, 'Ukazujem vam, da zaprete vrata. «3

Sklep, ki ga iz tega izpelje Austin, je takšen: če nismo prepričani, da je neka izjava performativna, jo vedno lahko »prevedemo « v njeno normalno oziroma kanonično obliko, to je, jo prefiksiramo z eksplicitnim performativom.

Ali to pomeni, da je performativ - in v zvezi s tem ponovno vztrajam na konceptu performativnosti, kakor ga je zamejil Benveniste, ki je nasprotoval razpustitvi performativa v ilokucijsko dejanje, na zamejitvi torej, ki vztraja na nujnosti, da mora sleherna »performativna izjava imenovati govorno dejavnost in njenega vršilca $\ll ;{ }^{4}$ namenoma se skratka omejujem na izjave, ki jim ponavadi pravimo eksplicitni performativi, in se sploh ne bom loteval izjav, ki bi utegnile (ali pa tudi ne) imeti neko potencialno ilokucijsko moč -, ali to torej pomeni, da performativ ni le polifon, temveč tudi - Bog obvaruj! - konstativen, vsaj v pojasnjevalnem smislu, to je, da pojasnjuje (ilokucijsko) moč izjave, katere nadaljevanje (oziroma pojasnilo) je?

Preden odgovorimo na to vprašanje, si najprej oglejmo t. i. Strawsonovo daljico. V slavnem Strawsonovem članku o intenci in konvenciji v govornih dejanjih je namreč razdelek, ki je, vsaj po mojem mnenju, premalo znan in cenjen, še manj pa uporabljan.

${ }^{3}$ J. L. Austin, Performatif-Constatif, v: La philosophie analytique, Pariz 1962, 174.

${ }^{4}$ E. Benveniste, Problemi splošne lingvistike I, Ljubljana 1988, 297. 
Ko govori o razmerju med dejanji, ki jih označuje kot »temeljno konvencionalna «, in dejanji, ki jih označuje kot »temeljno intencionalna«, ali natančneje, ko razpravlja o možnosti vpeljave konvencij v izvrševanje temeljno intencionalnih dejanj, Strawson ${ }^{5}$ pravi nekako takole:

Očitno moramo v tem primeru shemo razširiti, da bi tako naredili prostor za eksplicitno sklicevanje na družbene konvencije. Z nekaj truda jo lahko tako razširimo. Toda, globlje ko se pomikamo na področje institucionaliziranih postopkov, bolj postaja pritisk na shemo neznosen. Po eni strani moramo opustiti eno njenih temeljnih potez, sklicevanje na intence, ki naj zagotovi določen odgovor poslušalstva, po drugi strani pa sklicevanje na družbene konvencije vse bolj pridobiva na pomembnosti.

Nekoliko kasneje Strawson sklene:

$» V$ primeru ilokucijskega dejanja, ki ni temeljno konvencionalno, pride do izpolnitve komunikacijskega dejanja, če je zagotovljeno razumevanje (uptake), če je bila izjava (torej) podana s kompleksno odprto intenco, s katero naj bi bila podana. Toda, tudi če pride do izpolnitve komunikacijskega dejanja, je lahko odprta intenca, ki je jedro kompleksa intenc, onemogočena, ne da bi pri tem prišlo do kakršnekoli kršitue pravil in konvencij ... Povsem drugače je z izjavo, ki je del postopka, ki ga povsem obvladujejo konvencije. Če je razumevanje zagotovljeno, potem moramo sleherno onemogočenje povsem odprte intence izjave (intence, da bi postopek nadaljevali v določeni smeri) pripisati kršitvi pravila ali konvencije. Govorec, ki se drži konvencij, ima lahko izrecno intenco nadaljevati postopek v smeri, ki njegovemu trenutnemu govornemu dejanju konvencionalno ustreza le, če meni, da so konvencionalni pogoji za takšno nadaljevanje zadovoljeni, in je torej prepričan, da bo njegova izjava ne le razkrila njegove intence, temveć jim zagotovila tudi učinek. Nič podobnega ne moremo najti v primeru ilokucijskega dejanja, ki ni temeljno konvencionalno /vsi poudarki I. ̌̌. $\check{Z} . / \ll^{6}$

Igralec pokra bi tako lahko, na primer, bleknil Podvojim, ne da bi pri tem (res) imel intenco podvojiti vložek, toda če so okoliščine ustrezne in igra stroga, potem je podvojil vložek!

Soočeni smo torej z zelo nenavadno daljico: na njenih skrajnih polih imamo, na eni strani ilokucijska dejanja, ki so »temeljno intencionalna «, na drugi strani pa ilokucijska dejanja, ki so »temeljno konvencionalna«:

${ }^{5}$ P. F. Strawson, Intention and Convention in Speech Acts, (1969), v: K. T. Fann (ur.), Symposium on J. L. Austin, London, Henley 1969.

${ }^{6}$ N. d., 398. 


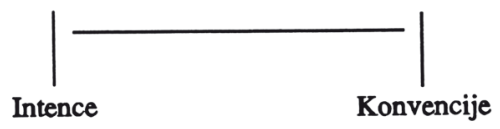

Toda, pravkar smo videli, da ta daljica ni $\gg$ zvezno prehodna «, da namreč ilokucijska dejanja, ki bi se razvrstila nekje na sredini te daljice, kjer naj bi se konvencije in intence stikale ali celo prehajale ene v druge, ne obstajajo, ali natančneje ne morejo obstajati: so namreč bodisi le konvencionalna bodisi le intencionalna:

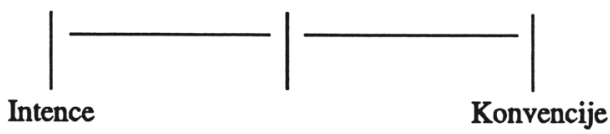

In celo več kot to!

Dejanja, ki so »temeljno konvencionalna«, lahko uspejo tudi, če govorec ni imel intence, ki naj bi bila potrebna za izvršitev tega dejanja, medtem ko »temeljno intencionalna « dejanja ne morejo uspeti, četudi je govorec storil vse, da bi sogovorec prepoznal njegovo intenco.

Sklep, ki ga iz tega lahko potegnemo, je seveda, da intence za uspeh performativov niso pertinentne: to, kar performativi potrebujejo, je minimum konvencionalnosti. »Temeljno konvencionalni« performativi se zaradi manka konvencionalnosti seveda ne morejo pritoževati: $\mathrm{v}$ večini primerov so prav družbene konvencije tiste, ki jo zagotavljajo. »Temeljno intencionalni« performativi pa se morajo s tem mankom neprestano soočati in ga seveda poskušati nekako (u)blažiti, zato - in to je moja (hipo)teza uprizarjajo podobo izjavljanja, kijev teku, (za)igrajo torej ta manjkajoči košček (družbene) konvencionalnosti, da bi na ta način zagotovili prepoznanje intencioniranega (performativnega) dejanja. Kaj to pomeni?

Ducrot, katerega teorijo argumentacije smo orisali na nekem drugem mestu, ${ }^{7}$ ne loči samo med govorečim subjektom kot empiričnim bitjem, in govorcem kot bitjem diskurza, temveč v okviru koncepta govorca, razlikuje tudi med več izjavljalci, ki so (tako) povsem diskurzivne in znotrajjezikovne entitete.

Govorec (avtor) je tisti, ki je odgovoren le za dejanje izjavljanja v najosnovnejšem smislu, to je za pojavitev dane izjave kot izjave, kot konkretne, partikularne realizacije abstraktne stavčne sheme, vokviru te izjave pa sooća oziroma daje besedo več izjavljalcem, in ti, ne govorec, so izvor stališč,

${ }^{7}$ I. Ž. Žagar, Argumentacija v jeziku proti argumentaciji z jezikom, Anthropos (1991), III/IV, $172-185$. 
izraženih $\mathrm{v}$ in z izjavljanjem (dane) izjave. Izjavljalci so tako elementi smisla izjave, njihova konfrontacija - konfrontacija njihovih stališč - pa tvori opis izjavljanja oziroma uprizarja njegovo podobo.

Lep primer oziroma natančneje lep dokaz polifone narave govora predstavljajo zanikane izjave. $\mathrm{Na}$ tem mestu jih omenjam predvsem zato, ker izvrstno dokazujejo, da izjavljalci v Ducrotovem smislu niso nikakršne izmišljotine.

Vzemimo izjavo

(7) Ta žoga ni rdeča.

Govorec te izjave sooča vsaj dva izjavljalca: prvega (I1), ki zatrjuje, da je žoga rdeča, in drugega (I2), ki tej izjavi nasprotuje (poudarjam: ne nasprotuje propozicionalni vsebini $\gg$ kot taki«, temveč propozicionalni vsebini kot izjavljeni).

Zakaj lahko ravnamo na tak način? Kaj naj avtorizira, da lahko znotraj ene same izjave razločimo kar dva izjavljalca?

V danem primeru že samo dejstvo, da v okviru tistega, čemur ponavadi pravimo realnost, ni ničesar, kar bi - »realno «, »materialno « - ustrezalo atributu $\gg$ ne-rdeč $\ll$, da v realnem svetu torej ni prav nikakršne entitete, ki bi jo lahko pozitivno opredelili kot ne-rdečo: imamo na primer le žoge, ki so zelene, rdeče, rumene itd. Seveda pa je ta(kšen) argument šepav, saj poznamo tudi takšne entitete, kakršni sta na primer »nezaceljena rana « ali »neposlikano platno«. Natančnejši odgovor na zgoraj zastavljeno vprašanje moramo torej iskati v polju izjavljalne logike, ne ontologije. $\mathrm{Z}$ drugimi besedami povedano to pomeni, da kadar pravimo (kadar trdimo), da nekaj ni x, nasprotujemo neki izjavi (ne stavku, temveč izjavi, torej njegovi vsakokratni in $s k o(n)$ tekstom pogojeni realizaciji) - morda predhodni, morda skriti (implicitni, zamolčani) -, ki trdi nasprotno. Govorec izjave (7) tako nujno sooča dva izjavljalca $z$ različnimi stališči in se staplja s tistim, ki nasprotuje zatrjevanju rdečosti žoge.

Seveda pa stališč različnih izjavljalcev ne moremo predstaviti tako, kot sem to storil v primeru ( 3 "). $\mathrm{Z}$ drugimi besedami povedano to pomeni, da stališčem različnih izjavljalcev, ki jih soočamo znotraj neke izjave, ne moremo pripisati enakega statusa, kot ga ima izjava, ki smo jo vzeli za predmet analize. Stališča posameznih izjavljalcev namreč niso nič drugega kot proizvod te iste analize, in imajo torej povsem abstraktno-teoretski status.

Stališč različnih izjavljalcev torej ne moremo in ne smemo predstaviti kot dejansko (in dobesedno) izrečene izjave, temveč le v obliki vmeščeno- 
sti (položajev) in usmeritev različnih izjavljalnih položajev, ki jih je mogoče razločiti znotraj dane izjave. $\mathrm{Na}$ ta način bi se lahko lotili analize primera $\left(1^{\prime}\right)$ s pomočjo govorca in (vsaj) treh izjavljalcev: ${ }^{8}$

I1 predstavi neko dejstvo D (na primer jutrišnjo zabavo, (lahko pa bi šlo seveda tudi za kaj povsem drugega, saj govorimo le o stališčih in usmeritvah, ne pa o konkretno in dobesedno izrečenih besedah)), in svojo predstavitev formulira (če seveda ostanemo pri primeru jutrišnje zabave) kot povabilo;

I2 soglaša s predstavitvijo I1 in sprejme povabilo;

I3 podvomi o iskrenosti I 2 in njegovo sprejetje povabila (sprejetje povabila s strani I2) predstavi kot dvomljivo;

I2' nasprotuje (dvomu) I3 in sprejem povabila potrdi z bolj zavezujočo obliko.

Upal bi si tvegati celo tole, argumentativno interpretacijo primera ( $\left.1^{\prime}\right)$ : govorec $\mathrm{G}$ (govorec, ki izjavlja $\left(1^{\prime}\right)$, in prav zaradi tega razloga) se staplja $s$ stališčem I2' in s tem argumentira za tak(šen)le sklep S: drugi poseg I2 (torej I2‘, s katerim se govorec staplja) je treba vzeti kot zadosten argument za njegov (I2) prihod.

Performativ bi bil tako ne le polifon - podoba (in opis) svojega lastnega izjavljanja skozi soočenje več izjavljalcev, ki bi sogovorcu s tem olajšala prepoznanje njegove ilokucijske moči - temveč tudi argumentativen: eksplicitni performativ (»Obljubljam, da bom prišel.«) bi tako nastopal kot močnejsi argument (za »moj prihod «) kot kaka druga izjava zle morebitno, potencialno ilokucijsko moćjo (na primer $\gg$ Pridem.«).

$\mathrm{V}$ potrditev pravkar povedanega bom povzel kar Austina samega. Že v svojem članku Other Minds iz leta 1939, v katerem se je prvič lotil performativne problematike, Austin primerja, po eni strani izjave kot Obljubljam, da ... in Imam namen, da ..., po drugi pa Vem, da ... in Mislim, da ..., in ugotavlja tole: dokler ostajam pri izrazih kot Imam namen, da ..., to, na neki način, zadeva le mene: le jaz sam namreč lahko vem, da je moj namen storiti to in to. In če bo moj sogovorec vzel takšen izraz mojih namenov kot

\footnotetext{
${ }^{8} \mathrm{Na} \gg$ vsaj « vztrajam zato, ker sem prepričan, da moramo, ko govorimo o izjavljalcih v Ducrotovem smislu, skrbno uporabljati »Ockhamovo britev«, in ne množiti jezikovnih entitet, če zato nimamo zadostnih (in seveda nujnih) razlogov. $\mathrm{Z}$ drugimi besedami: nikakor nisem prepričan, da za analizo pragmatičnih rab francoskega argumentativnega veznika toujours (prim. A. Cadiot, O. Ducrot, T.-B. Nguyen in A. Vicher, Sous un mot, une controverse: Les emplois pragmatiques de 'Toujours', v: Modèles linguistiques VII (1985), 2, 105-124) - gre za morda najbolj podrobno aplikacijo Ducrotove teorije polifonije v jeziku, ki smo jo že predstavili v poglavju Med argumentativnimi vezniki in polifonijo - res potrebujemo kar pet (5) izjavljalcev.
} 
zadostno zagotovilo za uspeh svojih dejanj, to, na neki način, zadeva le njega: ravnal bo v skladu s svojo oceno moje iskrenosti in moje zanesljivosti po eni strani, in mojih sposobnosti ter mojih zmožnosti po drugi strani.

Toda, takoj ko rečem Obljubljam, da ..., in ne več (le) Imam namen, da ..., je moj sogovorec upravičen ravnati oziroma celo mora ravnati, kot da bi obljuba sama v sebi nekako nosila svojo realizacijo, neodvisno od njegove ocene mojih zmožnosti in mojih sposobnosti, moje zanesljivosti in moje iskrenosti. Isto velja za Vem, da ... glede na Mislim, da ... (četudi Vem, da ... ni performativ).

Argumentativna interpretacija eksplicitnih performativov ni torej nič samovoljnega in povsem brez težav bi lahko zgradili argumentativno lestvico, na kateri bi eksplicitni performativ nastopal kot najmočnejši argument za (možnost) realizacije propozicionalne vsebine, sicer skupne vsem izjavam, ki se uvrščajo na isto argumentativno lestvico. Vzemimo torej našo začetno izjavo $\left(1^{c}\right)$, in dobili bomo takšnole lestvico:

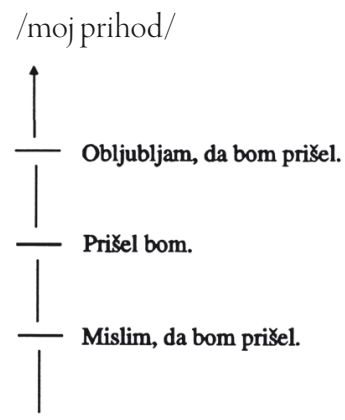

Navezavo dveh diskurzivnih segmentov, A(rgument) in S(klep), katerih prvi je predstavljen kot razlog, ki upravičuje drugega, (na primer, Zelo toplo je (A); Pojdimo se kopat! (S)), smo torej kondenzirali in ponotranjili v le enega, $v$ navezavo performativnega prefiksa (A), nastopajočega kot argument za realizacijo propozicionalne vsebine (S), ki jo vpeljuje.

\section{II}

Toda, ne pozabimo, da se še vedno nahajamo na $\gg$ temeljno intencionalnem « polu Strawsonove daljice. Kako pa se stvari odvijajo na »temeljno konvencionalnem « polu? Ali mu družbene konvencije res zagotavljajo potrebno enosmiselnost in enoglasnost? 
Austinu (in teoriji performativa sploh) so pogosto očitali, zlasti sociologi, da besedam pripisuje nekakšno notranjo magično moč. Bourdieu na primer piše:

»///lokucijske moči izrazov /.../ ni mogoče najti v besedah samih, kakor so »performativi«... Moč besed ni nič drugega kot delegirana moč pooblaščenega govorca, njegove besede /.../ pa v najboljšem primeru le eden od dokazov jamstva njegove pooblašcenosti. Poskušati lingvistično razumeti moč jezikovnih pojavov, v govoru iskati logični princip in princip učinkovitosti govorice institucije, pomeni pozabiti, da avtoriteta v govor prihaja od zunaj/vsi poudarki I. Ž. Ž. $/ \ll^{9}$

Res je in Austin ni tega nikoli zanikal - vsaj v svoji prvi teoriji ne - , prav to namreč trdi, ko govori o »primernih okoliščinah « in »pooblaščenih osebah «.

Toda, če je (res) tako, potem bi morali pravzaprav tudi na $\gg$ temeljno konvencionalnem « polu, na polu, ki nima potrebe, da bi z uprizarjanjem pogojev izjavljanja neke izjave blažil manko konvencionalnosti, ločevati med govorcem in (vsaj enim) izjavljalcem. Zakaj?

Preden odgovorimo na to vprašanje, premerimo (konceptualno) razdaljo med obema poloma naše daljice na primeru neke že malce zaprašene teorije, namreč moralne filozofije H. A. Pricharda. Ker smo o Prichardu podrobneje že pisali, ${ }^{10}$ bomo povzemajoč tisto najnujnejše, njegovo teorijo le prestavili v drugačen konceptualni okvir.

Prichard, ki je bil eden od Austinovih učiteljev, je danes pravzaprav neznan, njegovi spisi pa bodisi pozabljeni bodisi težko dostopni. Na razpolago imamo le drobno knjižico njegovih člankov, ki so leta 1965 izšli pri Oxford University Press pod naslovom Moral Obligation.

Kakor koli že, pred II. svetovno vojno je bil eden najbolj cenjenih profesorjev moralne filozofije v Oxfordu in čeprav je preziral filozofe Austinove generacije in vsakršno logično obravnavanje filozofskih problemov, sta se z Austinom medsebojno izjemno spoštovala.

Isaiah Berlin se spominja, da je Austin že v letih 1933-35 razpravljal o Prichardovih pogledih na »moralno zavezanost «, o temi torej, ki bo postala vir performativne diskusije, 1. 1947, leto dni po predstavitvi njegove prve performativne teorije filozofskima društvoma Oxforda in Cambrid-

${ }^{9}$ P. Bourdieu, Ce que parler veut dire, Pariz 1982, 105.

${ }^{10}$ Zainteresirani bralec bo podrobnosti našel v I. Ž. Žagar, Zagatnost performativnosti ali kako obljubiti, Ljubljana 1989, 23-30, ter v M. Grgič in I. Ž. Žagar, Čas in dejanje v jeziku: oblikovanje performativne teorije na Slovenskem, Ljubljana 2004. 
gea, pa sta s Prichardom celo izmenjala nekaj pisem o naravi obljubljanja, vendar se na žalost niso ohranila.

Problem obljubljanja, ali natančneje »zavezanost obljubi«, je bil Prichardova obsesija, ki je močno vplivala na njegovo delo in pustila sled v domala vseh njegovih delih. Najbolj zgoščeno ga je predstavil v članku $Z a-$ vezanost obljubi, napisanem leta 1940, kar nikakor ni nepomembna letnica, če vemo, da je Austin svojo prvo teorijo performativa razvil prav v letih 1940-46 (da niti ne omenjamo, da je bil v obeh teorijah njegov ključni zgled prav »obljubljanje «).

Kaj je, po Prichardovem mnenju, torej obljubljanje?

Očitno je, meni Prichard (1965), da obljubljanje zahteva uporabo besede »obljubljam《 ali kake druge ustrezne besede, kot »jamčim «, »soglašam«, »dajem ti besedo«, ali »bom«. Če je tako, lahko rečemo vsaj to, da s tem, ko X-u obljubljam, da bom izvršil neko dejanje, povzročim, da X sliši določen glas, ki ima skupaj z izrazom, ki se za dejanje ponavadi uporablja - tako zame kot zanj - , določen pomen, in to tako, da X verjame, da so glasovi prišli do mene.

Tu pa takoj nastopi drugo vprašanje, vprašanje, ki je bilo pravzaprav prava Prichardova preokupacija: zakaj me lahko k čemur koli zavezuje že to, da sem izustil nekaj glasov? Zato, ker sem bil že dal neko splošnejšo obljubo, pravi Prichard, ker sem že prej obljubil, da takšnih glasov ne bom izustil v povezavi s stavkom o nekem dejanju, ne da bi se lotil dejanja samega.

Reči obljubljam, pomeni Prichardu le izustiti nekaj »šumov«, ki ne morejo nikogar zavezati k ničemur - če seveda ne predpostavimo poprejšnje, splošnejše obljube. Toda, kaj to sploh pomeni, in predvsem, kako do te splošne prvinske obljube sploh priti?

Prichard tudi sam meni, da je nekoliko »zapleteno «, in predlaga, da ravnamo takole: zamislimo si lahko stopnjo, na kateri (še) ne mislimo, da se z uporabo tega ali onega jezikovnega obrazca zavežemo, da bomo izvršili dejanje. In lahko se vprašamo takole: bi si na tej stopnji lahko vsaj želeli, da bi se bili z uporabo nekega posebnega jezikovnega obrazca sposobni zavezati? In če bi si lahko: ali obstaja kak korak, s katerega podvzetjem bi se res zavezali?

Jasni sta dve stvari, meni Prichard:

1. Držati obljubo ni prvo dejanje, ki mu je človek zavezan. Kajti če pozna smisel obljube ali dejanje obljubljanja, mora poznati tudi nekaj splo- 
šnejšega, nekakšno obvezo, in potemtakem (tudi) druga dejanja, ki so (kot) dolžnosti.

2. Obljubljamo lahko le v skupini vsaj dveh ljudi, katerih vsak je prepričan in se pri svojem ravnanju do neke mere zanaša na prepričanje, da so drugi bitja, ki ne le mislijo, da imajo določene obveze, temveč bodo verjetno tudi storili, kar mislijo, da so zavezani storiti.

Da je obljubljanje torej sploh lahko mogoče, mora obstajati skupina ljudi, ki ima določene obveze in se jih tudi zaveda. Uspeh slehernega napora, da bi dosegli lastno dobrobit, torej ni odvisen samo od dejstva, da bodo drugi ravnali na določen način in da se bodo določenega ravnanja vzdržali (ker menijo, da je to njihova dolžnost), temveč tudi od naše zmožnosti, da se zanesemo na prepričanje, da bodo tako ravnali.

Vendar pa nam kaj kmalu postane jasno, nadaljuje Prichard, da tudi za uresničitev vsaj zmerno obetavnih načrtov potrebujemo več. Za ugotovitev, da je potrebno več, je dovolj, da se zavemo, da skoraj vse dejavnosti, ki so pomembne za našo lastno dobrobit, zahtevajo tudi sodelovanje nekoga drugega, in da nato pretehtamo, kaj je potrebno, da bi bilo sodelovanje možno.

Potrebna pa je prav ... uporaba jezika v najširšem pomenu besede ...

Da bi takšno sodelovanje torej naredili možno, Prichard predlaga tale postopek:

»Najprej si izberimo določen glas ali znamenje na papirju, ki bi ga lahko uporabiliv povezavizizrazom za neko dejanje, nato pa se dogovorimo ali (si) obljubimo, da tega glasu ali znamenja ne bomo uporabili v povezavi z izrazom za to dejanje, ne da bi se lotili dejanja samega. Če to storimo, smo dosegli cilj, kajti če po tem uporabimo glas ali znamenje na tak način, bomo vzpostavili obveznost izvršitve dejanja v skladu z našim splošnim dogovorom ali obljubo. «"

Tisto, na kar sem želel opozoriti s tole obsežno predstavitvijo Prichardovega dela, niso toliko Prichardovi mitično-transcendentalni postopki, vzeti dobesedno, temveč bolj njihov duh, ideja, ki stoji za njimi, namreč predpostavka, da obljuba sama na sebi - obljuba kot taka, kot beseda, kot govorno dejanje med govornimi dejanji - ni dovolj močna, da bi lahko zagotovila uresničitev, realizacijo vsega tistega, za čemer - oziroma natančneje pred čemer - stoji, vsega tistega, kar je - če so seveda okoliščine prave, obljubovalec pa pooblaščen - njen rezultat in učinek, temveč da predpo-

${ }^{11}$ H. A. Prichard, Moral Obligation, Oxford 1965, 177. 
stavlja mrežo (vsaj virtualnih) izjavljalcev, da bi sploh lahko imela želeno kredibilnost in zahtevano (ilokucijsko) moč.

Gre torej za predpostavko, po kateri obljuba oziroma eksplicitni performativ sploh ni nič drugega kot kristalizacija poliloga in kristal(izacija) svojih lastnih pogojev izjavljanja. V nasprotnem primeru ni in ne more biti nič drugega kot le nekaj »šumov«, kakor zatrjuje Prichard, in kar pravzaprav potrjuje tudi vsakodnevna izkušnja.

Tisti, ki svečano krsti novo zgrajeno ladjo (kakor v slavnem Austinovem primeru), tako ne more biti nič drugega, nič več, kot le govorec; izjavljalec, s katerim se staplja, pa nekaj kar Bally - analizirajoč opozorilo $\gg$ Kaditi prepovedano $\ll-$ imenuje $\gg$ moralna entiteta $\ll .{ }^{12}$

Iz Prichardovega poskusa konstrukcije takšne »moralne entitete « pa smo videli, da moralna entiteta ni nič enotnega, da ne govori z enotnim glasom oziroma natančneje: govori sicer res z enotnim glasom, toda le tako, le na račun tega, da prikriva pluralnost glasov.

Seveda lahko gremo še dlje: da bi performativ lahko uspel na $\gg$ temeljno konvencionalnem « polu, pluralnost glasov mora biti prikrita, kar seveda ni presenetljivo: da bi bila neka družbena konvencija lahko učinkovita, mora govoriti z enim enotnim glasom. Dokaz za to je na primer v tem, da na »temeljno konvencionalnem « polu ne moremo zgraditi argumentativne lestvice: ne moremo namreč reči, da je izjava To ladjo krstim za Svobodo močnejši ali šibkejši argument za možnost realizacije njene propozicionalne vsebine, kot kaka druga izjava. Nasprotno, le s to izjavo lahko ladjo krstimo - in prav družbene konvencije so tiste, ki to zahtevajo.

${ }^{12}$ Primer si izposojam iz: O. Ducrot, L' énonciation et polyphonie chez Charles Bally (1986), v:
O. Ducrot (ur.), Logique, structure, énonciation, Pariz 1989, 189. 



\title{
Pa, modifikator veznikov
}

\author{
Argumentativna \\ analiza ${ }^{1}$
}

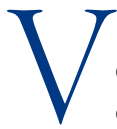

eznik $p a^{2}$ (v angleščino se običajno prevaja kot and ali $\left.b u t\right)$ velja za enega (kontekstualno) najbolj raznolikih in najširše rabljenih leksemov v slovenščini, ki je na drugi strani tudi eden najmanj raziskanih. Slovar slovenskega knjižnega jezika (v nadaljevanju SSKJ) ločuje med štirimi glavnimi rabami veznika pa:

a) v protivnem priredju, $z$ vejico;

b) med členi v stavku, brez vejice;

c) v vezalnem priredju, brez vejice, navadno z izpuščanjem pomožnih besed $\mathrm{v}$ drugem stavku;

d) za piko ali podpičjem.

Znotraj štirih glavnih rab je opredeljenih veliko število različic, od katerih navajamo 29 poglavitnejših.

\footnotetext{
${ }^{1}$ Deli pričujočega poglavja so bili objavljeni v različnih oblikah: I. Ž. Žagar, Konstrukcija topičnega polja slovenskega jezika: veznik "pa", (raziskovalno poročilo), Ljubljana 1989; I. Ž. Žagar, O polifoniji, argumentativnem pričakovanju in njegovem sprevračanju (ali kaj veznik pa dolguje veznikoma ker in sicer), Časopis za kritiko znanosti 19 (1991), 140/141, 111-130; I. Ž. Žagar, »Pa«, the reverser of argumentative expectation, Filozofski vestnik 12 ( 1991) 1, 179-192. ${ }^{2} \mathrm{~Pa}, \mathrm{ker}$, sicer in druge lingvistične entitete, ki se jih lotevam v tem članku, veljajo običajno (in zlasti v okviru slovničnih teorij) za členke. Ker obravnavam njihovo argumentativno funkcijo v smislu povezovanja argumentov z drugimi argumenti ali argumentov s sklepi, jih bom imenoval argumentativni vezniki.
} 
Ad a)

I - za izražanje nasprotja s prejpovedanim

(1) Obljubil je bil, pa ni držal besede.

\section{II - za izražanje nepričakovanega}

(2) Nihče ni mislil nanjo, pa je stopila v hišo.

III - za izražanje rablega nasprotja

(3) Po travi so pajčevine, na njih pa se blešči rosa.

IV - za dopolnjevanje, pojasnjevanje prejpovedanega

(4) Potrebno nam je znanje, pa resnično znanje.

\section{$\mathrm{V}-$ za krepitev prislova, ki uvaja zadnji člen zaporedja}

(5) Dela v tovarni, hodi na lov, pa še kmetuje pomalem.

\section{$\mathrm{VI}-$ za stopnjevanje}

(6) Pozdrav vsem, posebno pa očetu.

\section{VII - za izražanje vzročno-posledičnega razmerja}

(7) Ni plačal davkov, pa so ga rubili.

VIII - za izražanje vzročno-sklepalnega razmerja

(8) To je zanimiv primer, pa je prav, da si ga ogledamo.

IX - za izražanje pogojno-posledičnega razmerja

(9) Njo bi vzel, pa bi bilo drugače.

$\mathrm{X}$ - za izražanje dejstva, kljub kateremu se dejanje prejšnjega stavka uresniči (10) Jože je odličnjak, pa nima inštruktorja kakor ti.

$\mathrm{XI}$ - za poudarjanje nasprotja

(11) Moja bo obveljala, pa če se na glavo postaviš.

Ad b)

XII - za vezanje dveh istovrstnih členov

(12) Pospravi krožnike pa kar je še na mizi.

XIII - za vezanje predzadnjega in zadnjega člena

(13) Šumenje macesnov, borovcev pa smrek.

$\mathrm{XIV}$ - za stopnjevano poudarjanje členov

(14) Fant je še mlad pa norčav pa zaljubljen. 
$\mathrm{XV}-$ za vezanje dveh sorodnih pojmov v pomensko enoto

(15) Ves vik pa krik je zaman.

XVI - za izražanje velike količine, visoke stopnje

(16) Tam je sam pesek, pa spet pesek.

XVII - za seštevanje, prištevanje

(17) Star je pet let pa tri mesece.

XVIII - za dodajanje

(18) Povedala je samo materi, pa (še) teti.

XIX - vzvezi 'ta pa ta', 'tak pa tak', kije znan, a se noče, ne more imenovati

(19) To pa to bi bilo treba urediti.

Ad c)

$\mathrm{XX}$ - za vezanje dveh stavkov, ki izražata sočasnost ali zaporednost

(20) Pili so, peli pa šale zbijali.

XXI - za stopnjevano poudarjanje stavkov

(21) Fant hodi samo v kino pa gleda televizijo pa bere stripe.

XXII - za vezanje dveh sorodnih povedkov vpomensko enoto

(22) Ves dan vije pa razgraja.

XXIII - za izražanje intenzivnosti dejanja

(23) Ne dam pa ne dam.

XXIV - za izražanje namena

(24) Pojdipa zapri vrata.

Ad d)

$\mathrm{XXV}$ - za izražanje pomenov kakorpod a) in c)

XXVI - ekspresivno

(25) Bodite mirni. Pa nobenega šepetanja.

XXVII - za navezovanje na prej povedano

(26) Jaz sem končal. Pa ti?

XXVIII - za opozoritev na prehod $k$ drugi misli

(27) Pa še to. V̌̌eraj mi je pisal Janez. 
XXIX - za izražanje začudenja, presenečenja, nejevolje

(28) Pa da mi nikdar več ne greš tja.

Skoraj vse naštete primere rabe $p a$ bi $\mathrm{v}$ angleščino lahko prevedli kot and (in včasih but) ali, natančneje, nadomestili z in, ki velja za slovensko (nezaznamovano) dvojnico angleškega and.

Če to klasifikacijo primerjamo s korpusom slovenskega (govorjenega in pisanega) jezika Nova beseda, ${ }^{3}$ kaj kmalu ugotovimo, da obstaja še neka druga raba pa. Primerjajmo (29)-(31) s (32)-(36):

(29) JANKO: Drugače te ne bi ovadil. Sicer pa, kaj naj drugega počnem. Naj jarke kopljem?

(30) Postala je ujetnica v zlati kletki in ugrabitelj je uporabil vsa sredstva, ki jih ponuja bogastvo, da bi jo omrežil in zapeljal. Ker pa je premogla veliko duševno moč, v kateri jo je podpirala vera, ni popustila prilizovanjem tega človeka, ki je bil za kraljem najmogočnejši veljak Anglije.

(31) Ni mi preveč pri srcu, nikakor pa ga nisem umoril.

(32) Tam raziskujem že eno leto, dve leti dela pa sta še pred mano. Pravkarpa sem napisal še en predlog, in če bo sprejet, to pomeni še dodatna tri leta dela na Antarktiki, je povedal dr. Hansen.

(33) Že na prejšnjih tekmovanjih se je šušljalo, da se zadnje leto praktično nepremagljivi par razhaja. Govorice so se izkazale za resnične, bojda pa trenutno oba iščeta nova partnerja.

(34) Nisem videl samo belih obrazov, temveč tudi rumene, bronastorjave in čisto črne. Kakor pa so si bili obrazi različni po rodu in plemenu, po letih in oblikah, nekaj jih je družilo, kar sem občutil v srcu, ko sem jih gledal, ali kar se nikakor ne dá razložiti z besedo.

(35) Nekateri ne pozabijo. Vendar pa to nič ne spremeni, ker se te potem na cesti vseeno izognejo.

(36) 'Prav vesela sem, da za rojstni dan ne dobivam takšnih daril!' Seveda pa tega ni rekla na glas.

Če izpustimo pa v sestavljenem vezniku v primerih (29)-(31), se spremenita njegov pomen in funkcija (kakor tudi pomen samih primerov). $\mathrm{Na}$ drugi strani je v primerih (32)-(36), vsaj kar zadeva pomen in funkcijo, pa

${ }^{3}$ http://bos.zrc-sazu.si/s_beseda.html 
mogoče izpustiti. Tisto, kar se spremeni, je moč preostalega veznika: slednji brez pa postane šibak in manj natančen. Zakaj?

Moja (hipo)teza je, da ima v določenih sestavljenih veznikih pa vlogo bodisi modifikatorja - sprevračevalca - argumentativnega pričakovanja in usmerjenosti (kot v primerih (29)-(31)) bodisi modifikatorja - okrepitelja - pomena in moči predhodnega veznika (kot v (32)-(36)) in ne le propozicionalnega (ali gramatičnega) operatorja (kot v (1)-(28)). V tem prispevku bom skušal osvetliti to specifično rabo $p a$, še posebej tiste primere, kjer $p a$ nastopa kot modifikator argumentativnega pričakovanja in usmerjenosti. Pokazal bom, da je v zadnjem primeru pa nastopa kot neke vrste diskurzivna metafora, ki sega onkraj potekajočega diskurza, da bi ga podprla in mu dala (vsaj relativno) ${ }^{4}$ interpretativno avtonomijo in neodvisnost.

\section{Logika proti argumentaciji v jeziku}

Ker bomo kot eno od metod analize primerov iz časopisa uporabili tudi Ducrotovo teorijo argumentacije v jeziku, na tem mestu na kratko obnovimo, kaj smo o TAJ že povedali. ${ }^{5}$

$\mathrm{V}$ teoriji argumentacije $\mathrm{v}$ jeziku nekateri argumentativni vezniki nimajo le izjemne usmeritvene moči, ampak nam kopičenje ali »blaženje« različnih argumentativnih veznikov pomaga jasneje uvideti, kakšna je ta usmeritvena moč (usmerjenost). Vendar je argumentativno razmerje (med argumenti in sklepom) drugačno od logičnega razmerja (med premisami in sklepom). Nekateri sklepi, ki so sicer argumentativno (in diskurzivno) povsem sprejemljivi, so logično nesmiselni. Spomnimo se tegale pogovornega odlomka:

(37) A: Je večerja že nared?

B: Ja, skoraj.

V logiki je ta dialog povsem nesmiseln. Večerja je lahko bodisi že nared bodisi $\check{s}$ e ni nared. Lahko je sicer tudi skoraj nared, kar pa, logično vzeto, pomeni, da še ni nared. ZatorejJa, skoraj, nikakor ne more biti odgovor na vprašanje Je večerja že nared, kajti s tem bi izjava ${ }^{6}$ postala protislovna, namreč: Ja, večerja še ni nared.

A kot smo že ugotovili, je ta dialog pragmatično sprejemljiv in to sprejemljivost dolguje prav (problematičnemu) vezniku skoraj. Kajti (izjava)

${ }^{4}$ Relativno v zvezi z neposrednim ko(n)tekstom. Nazornejšo opredelitev bom podal v nadaljevanju. ${ }^{5}$ Zaradi večje nazornosti si bomo iz predhodnih poglavij izposodili tudi primere in njihove analize.

${ }^{6}$ Vsi znaki za 'izjavo', z izjemo tistih, ki so vzeti iz analiziranih člankov, so mišljeni kot možne in ne resnične izjave. 
Večerja je SKORAJ nared argumentira v prid nekega implicitnega sklepa, kot je npr. Treba je pohiteti. Isti sklep prav tako podpira (logično čistejši') argument Večerja je $\check{Z} E$ nared, ki je (za implicitni sklep Treba je pohiteti) močnejši od argumenta Večerja je SKORAJ nared, oba pa sta enako argumentativno usmerjena. Tako na argumentativni lestvici, kot jo vidimo $\mathrm{v}$ primeru (38),

(38) / pripravljenost večerje/

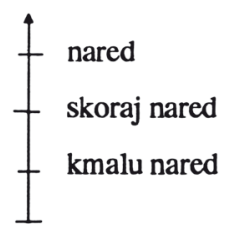

četudi je šibkejši, argument Večerja je skoraj nared podpira isti sklep kot močnejši (ali najmočnejši) argument s prikazane lestvice. Argumentativna usmerjenost je torej, ne glede na kontekst, vpisana v sam veznik skoraj. Vsak argument, ki vsebuje ta veznik, tako predstavlja omejitev za nadaljevanje diskurza: sklep, ki mu sledi, mora (argumentativno) ustrezati smeri, ki jo je začrtala oziroma zamejila raba prislova skoraj. Z drugimi besedami: od Večerja je SKORAJ nared je nemogoče sklepati (v smeri) Še je čas, ni ti treba hiteti (razen če ne vpeljemo dodatnih veznikov, ki ublažijo začetnega).

Kot eno ključnih izhodišč v TAJ smo v predhodnih poglavjih opredelili prehod od A(rgumenta) do S(klepa), ki je mogoč s pomočjo (običajno implicitnega) sklicevanja na določene sheme podatkov iz ozadja in jih Ducrot imenuje topoi. Temeljno zgradbo topoi bi lahko predstavili s tema dvema oblikama:

(39) Boljko (je nekaj)P, bolj (je nekaj)Q

(Bolj ko je toplo, prijetneje se je sprehajati)

ali

$$
\begin{aligned}
& \text { (40) Manjko (je nekaj) P, manj (je nekaj) } Q \\
& \text { (Manj ko je toplo, manj prijetno se je sprehajati.) }
\end{aligned}
$$

Povzemimo še nekaj značilnosti topoi. Gre za splošne (in obenem zelo abstraktne), skupne in skalarne sheme ali matrice, ki omogočajo množico partikularnih sklepov, ki pa niso obvezni in obvezujoči na način silogizma ali logične dedukcije. Topos (t. j. sklicevanje na topos, uporaba ali njegov priklic) lahko neki sklep omogoči, a govorca k temu sklepu ne zavezuje. So- 
govorec sicer lahko priznava veljavnost (primernost) toposa, ki smo ga uporabili pri sklepanju, ne da bi se z njim strinjal. Kak drug topos se mu bo zdel primernejši za dano situacijo in z njim bo podprl nek drugi sklep.

Topoi so skupni (neki skupnosti) v tem, da skupnost priznava njihovo veljavnost in primernost sklepov, ki temeljijo na njih. To pa seveda ne implicira, da bi vsak pripadnik te skupnosti nujno v enaki situaciji uporabil enak topos. Uporabo nekega toposa in sklep, ki ga ta topos omogoča, je vedno mogoče izpodbijati, toda le $\mathrm{z}$ aplikacijo nekega drugega toposa, ki podpira nek drugi sklep. Ducrot je hevristično opredelil tole aplikacijo toposov kot 'močno' in 'šibko':

- močno pomeni topos aplicirati tako, da je le malo argumentov, ki bi bili močnejši od uporabljenega;

- šibko pomeni topos aplicirati tako, da je le malo argumentov, ki bi bili šibkejši od uporabljenega.

Toda kaj je z močjo argumentov? Spomnimo se primera z dvodelnimi argumentom v prvem poglavju. Prvemu delu argumenta smo rekli A, drugemu pa B. Nato smo vpeljali dve (hevristični) definiciji

1. Argument $\mathrm{A}$ je šibkejši od $\mathrm{B}$, če velja: $A$, in celo $B$.

2. Argument $\mathrm{A}$ je močnejši od $\mathrm{B}$, če velja: $B$, in v najboljšem/najslabšem primeru $A$.

in ti dve definiciji preverili na dveh konkretnih primerih:

A $\quad$ B

(41) To je prehlad ali v najslabšem primeru gripa. $\rightarrow$ Bodite brez skrbi!

A $\quad$ B

(42) To je pljučnica ali v najboljsem primeru huda gripa. $\rightarrow$ Pazite se!

Povzemimo še interpretacijo zgornjih primerov. Argumentativni niz (41) se lahko nanaša na neki topos kot Manj ko smo bolni, manj je vzroka za zaskrbljenost, argumentativni niz (42) pa na neki topos kot Bolj ko smo bolni, več je vzroka za zaskrbljenost. Argumenta A sta v luči naše definicije močnejša kot argumenta B, kar pomeni, da če dani sklep sledi iz B, potem mora slediti tudi iz A. Z drugimi besedami to pomeni, da obe (možni) izjavi aplicirata »svoja« toposa močno. Glede na argumentativni lestvici, ki ju lahko konstruiramo v skladu z našim poznavanjem moči argumentov v obeh izjavah: 
(43)

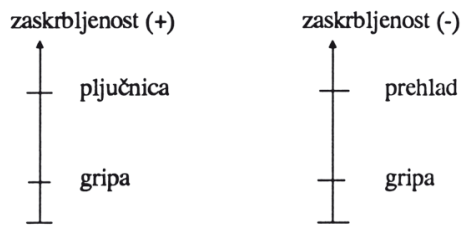

lahko rečemo, da obe izjavi aplicirata »svoja« toposa in smeri argumentativnih lestvic, da torej težita $\mathrm{k}$ močnejši aplikaciji toposov. Če zamenjamo argumentativna veznika kot v $\left(41^{\circ}\right)$ in $\left(42^{\circ}\right)$ :

\section{A B}

$\left(41^{`}\right)$ To je prehlad, celo gripa. $\rightarrow$ Pazite se!

A B

$\left(42^{\prime}\right)$ To je pljučnica, celo (huda) gripa. $\rightarrow$ Pazite se!

lahko ugotovimo, da zamenjava argumentativnega veznika zamenja (obrne) moč argumentov (B je zdaj močnejši kot $A$ ), s tem pa tudi samo argumentativno usmerjenost. Iz argumenta To je prehlad, celo gripa, ne moremo več sklepati Bodite brez skrbi, temveč le Pazite se, kar je tudi povsem v skladu z argumentativno lestvico zaskrbljenosti (-), na kateri se 'gripa' nahaja niže kot 'prehlad' in $s$ tem (ker je lestvica negativna) bliže vzroku za zaskrbljenost.

Da bi pokazali, kako odločilna je izbira argumentativnega veznika (oziroma veznikov), zamenjajmo sedaj veznik v primeru (42). '(Hudi) gripi', ki je na argumentativni lestvici zaskrbljenosti (+) nižje od 'pljučnice', že sama prisotnost celo podeljuje vrednost močnejšega argumenta in $s$ tem napeljuje $\mathrm{k}$ sklepu Pazite se. Argumentativna usmerjenost, vpisana v celo, namreč ne dopušča, da bi bil argument, ki mu sledi, šibkejši od onega, ki mu predhaja. Nasprotno, argument, ki ga uvaja celo, naj bi potenciral moč predhodnega argumenta. Če se torej hočemo izogniti aplikaciji nekega toposa, kot je Manj ko smo bolni, več je vzrokov za zaskrbljenost (ki bi lahko bil splošen, a komajda skupen), in ponovno vzpostaviti argumentativno ravnovesje, moramo vpeljati dodatni argumentativni veznik kot v (42“):

$\left(42^{\prime \prime}\right)$ To je pljučnica, celo le (huda) gripa. $\rightarrow$ Bodite brez skrbi.

ali celo (!)

$\left(42^{\prime \prime \prime) ~ T o ~ j e ~ p l j u c ̌ n i c a, ~ m o r d a ~ c e l o ~ l e ~(h u d a) ~ g r i p a . ~} \rightarrow\right.$ Bodite brez skrbi. 
Če le blaži in sprevrača potencialno argumentativno usmerjenost celo, pa morda blaži potencialno logično nasprotje med priredno postavljenima trditvama: če gre pri bolezni za pljučnico, potem pač ne gre za (hudo) gripo in obratno. Če oba propozicionalna elementa umerimo z morda, ju postavimo izven logične nujnosti, kjer sta lahko (le) bodisi resnična ali neresnična.

Kot vemo, Ducrot pozna tudi 'srednje močno' oziroma 'srednje šibko' aplikacijo nekega toposa. Ob koncu tega kratkega orisa TAJ se spomnimo še analize spodnjih primerov:

(44) Steklenica je že na pol prazna. $\rightarrow$ Treba bo odpreti drugo.

((44) aplicira neki topos kot Boljko se pije, većpijače je potrebne)

(45) Steklenica je ̌̌ š na pol polna. $\rightarrow$ Ne bo še treba odpreti druge.

((45) aplicira neki topos kot Manjko se pije, manjpijače je potrebne)

Po Ducrotu neka izjava aplicira neki topos Tx srednje močno, če istočasno dovoljuje srednje močno aplikacijo nekega toposa Ty. To velja za primera (44) in (45). Toda lepota 'srednje močnih' (ali 'srednje šibkih') aplikacij je v njihovi eksplicitni razgrnitvi tega, kar je informativno, in tega, kar je argumentativno v jeziku: 'že na pol prazna' in 'še na pol polna' opisujeta informativno isto stanje (nivo tekočine v steklenici ostaja isti, ne glede na to, kako ga opišemo), toda njuna argumentativna usmerjenost je nasprotna, prav tako pa tudi sklepa, $\mathrm{k}$ katerima napeljujeta. 'Že na pol prazna' in 'še na pol polna' aludirata na dejavnost praznjenja, ne polnjenja steklenice. Če zamenjamo mesti obeh argumentativnih veznikov, tako da dobimo ‘̌e na pol prazna' in 'že na pol polna', novi sintagmi ne bosta le drugače argumentativno usmerjeni, temveč bo ta zamenjava takoj ustvarila nov potencialni kontekst: sedaj nimamo več opraviti s procesom praznjenja, temveč s procesom polnjenja.

\section{Ker pa in sicer pa - analiza}

V luči tega, kar smo pravkar povedali, si oglejmo vlogo veznika pa in sestavljenih veznikov ker pa in sicer pa. Za začetek primerjajmo izjave s pa ali brez njega v sledečih primerih:

(46) Ker si razbil šipo, ne boš šel v kino.

(47) Pridi sem, sicer pridem pote.

\footnotetext{
${ }^{7}$ Izbor veznikov ker in sicer nikakor ni arbitraren. Študij korpusa slovenskega jezika Nova beseda pokaže, da ker in sicer $v$ sestavljenih veznikih s pa bistveno spremenita svojo funkcijo in argumentativno usmerjenost. To se, denimo, ne zgodi s kakor $\mathrm{v}$ kakor $p a$ ali vendar $\mathrm{v}$ vendar pa, kjer $p a$ večinoma poudarja funkcijo in argumentativno usmerjenost kakor in vendar.
} 
(46) Kerpa si razbil šipo, ne boššel v kino.

(47’) Pridi sem, sicer pa pridem pote.

Primer (46) vsebuje neke vrste vzročno-posledični ker, ki argumentativno povezuje dve govorni dejanji: trditev (asertiv), da je ogovorjena oseba razbila šipo (argument) in prepoved (direktiv) njegovega/njenega odhoda $\mathrm{v}$ kino (sklep). Ker kot argumentativni veznik povezuje obe govorni dejanji tako trdno, da se primer (46) kot (potencialni) diskurzivni segment izkaže za interpretativno avtonomnega (izbor vsake sestavine izmed teh potencialnih diskurzivnih segmentov je pogojen z izborom celote (drugih segmentov)) in neodvisnega (do določene stopnje odraža (potencialno) izjavljalno situacijo in ne zahteva dodatnih ko(n)tekstualni informacij za njeno interpretacijo).

Toda kaj se zgodi, če vstavimo pa kot v primeru (46')? Prva stvar, ki jo opazimo, je dramatična sprememba pomena (sedaj) sestavljenega ker pa in izguba interpretativne avtonomije in neodvisnosti izjave. To pomeni: da bi razumeli in interpretirali $\left(46^{\circ}\right)$, moramo predpostavljati, da ker pa lahko aludira na nek možni (predhodni) argument za nasprotni sklep (Labko boš šel v kino), ki ga v danem argumentativnem nizu pravzaprav ni. A natanko ta 'manjkajoči' argument je (implicitno) zavrnjen v (46') kot nezadosten in iz njega je potegnjen dejanski sklep (Ne bošš šl v kino). Da bi bila izjava (46") interpretativno avtonomna in neodvisna, moramo rekonstruirati ta (implicitni) del diskurza, na katerega se lahko nanaša $p a .{ }^{8} \mathrm{Na}$ primer:

(46") Res si bil priden: pomil si posodo in pobrisal prah. $\rightarrow$ Kerpa si razbil šipo, ne bošš

Vrnimo se sedaj k primeru (47). Sicer brez težav parafraziramo kot disjunktivni ali-ali:

Alipridešsem, alipridempote. Vpeljava pa v takšno parafrazo ne povzroča interpretativnih problemov; pravzaprav ne povzroči nobenih sprememb v pomenu: Ali prideš sem ali $P$ A pridem pote. Toda razmere se spremenijo, ko $p a$ vpeljemo v sestavljeni veznik skupaj s sicer, kot v (47`):

(47`) Pridi sem, sicer pa pridem pote.

Intuitivno je primer (47’) nesmiseln: v nadrednem stavku govorec/govorka izreče ukaz (drugi osebi) za uresničitev dane propozicionalne vsebi-

${ }^{8}$ Rekonstrukcija v tem primeru ne pomeni natančne in dobesedne rekonstrukcije določenega dela diskurza, temveč pomeni rekonstrukcijo tipa (dela) diskurza, ki lahko vodi k določenemu sklepu oziroma določenim sklepom. 
ne, medtem ko v odvisnem stavku pravi, da ji bo resničnostno vrednost zagotovil/zagotovila $\mathrm{z}$ lastnim delovanjem. V podkrepitev navajamo še nekaj drugih primerov:

(48) Ugasni luč, sicer (pa) jo bom sam.

(49) Povrni mi povzročeno škodo, sicer ( $p$ a) te bom prisilil, da mi jo povrneš

(50) Zapri vrata, sicer $(p a)$ jih bom sam.

Primere (48)-(50) lahko interpretiramo kot disjunktivni ali - ali; toda če vanje vstavimo pa, odvisni stavek, ki ga uvaja sicer pa, na nek način razveljavlja ilokucijsko moč nadrednega stavka ( $v$ našem primeru ukaza) in podeljuje celotnemu segmentu ambivalenten, celo nesmiseln status. V nadrednem stavku govorec/govorka nekomu nekaj ukazuje, medtem ko v odvisnem stavku trdi, da bo to storil/storila sam/sama. Zatorej se $\mathrm{zdi}$, da $\left(47^{\circ}\right)$ - prav tako kakor vsi drugi primeri, kjer odvisni stavek uvaja sicer $p a$ - interpretativno ni avtonomen in neodvisen. Toda, $\mathrm{v}$ nasprotju s (46), v tem primeru ni jasno, kako konstruirati tisti (implicitni) diskurzivni segment, na katerega bi se pa utegnil nanašati (in nekoliko osvetliti možni kontekst), ne da bi ob tem spremenili samo izjavo.

Toda, kot kažejo spodnji primeri, to ni edina raba sicer pa, ki jo pozna slovenščina:

(51) Petra je vzela ključe. $\leftarrow$ Sicer pa to ni prvič.

(52) Avto je fuč. $\leftarrow$ Sicer pa tako ni bil vreden piškavega oreha.

(53) Prešeren je bil velik pijanec. $\leftarrow$ Sicer pa je to znano.

Izpeljimo sedaj nasproten postopek kot v primerih (48)-(50) in izpustimopa:

$\left(51^{\prime}\right)$ Petra je vzela ključe. $\leftarrow$ Sicer to ni prvič.

$\left(52^{\prime}\right)$ Avto je fuč. $\leftarrow$ Sicer tako ni bil vreden piškavega oreha.

(53’) Prešeren je bil velik pijanec. $\leftarrow$ Sicer je to znano.

Primerom (51') do (53') manjka interpretativne avtonomije in neodvisnosti - zdi se, kot da so nedokončani in nekako »obvisijo v zraku«. Da bi jih naredili za avtonomne in neodvisne, bi jih morali dopolniti, denimo: $\left(51^{\prime}\right)=\ldots$ vendar bi vseeno labko prej povedala $;\left(52^{\prime}\right)=\ldots$ vendar je bil še vedno uporaben $;\left(53^{\prime}\right)=\ldots$ vendar za oceno njegove pesniške veličine to nipomembno. In medtem ko je takšna dopolnila mogoče uvesti le v obliki protivnih stavkov, so primeri (51) do (53), kjer je uporabljen sestavljeni veznik 
sicerpa, diskurzivno in interpretativno povsem avtonomni in neodvisni po lastni zmožnosti.

V nasprotju s kerpa, sicer pa danega diskurzivnega elementa ne oblikuje v neodvisnega zgolj z referenco na nek (potencialni) predhodni diskurzivni segment ali situacijo. Nasprotno, zdi se, da sicer pa pojasnjuje, slabi in celo zavrača ta (potencialni) predhodni diskurzivni segment prav s tem, ko eksplicira neko predhodno, a v potekajočem diskurzu neizraženo informacijo (ali vednost). Povedano z drugimi besedami, pa, ne le da sega nazaj v potekajoči diskurz z namenom, da bi pojasnil dani, izražen diskurzivni segment, temveč seže tudi onkraj in vstopa v območje implicitnih (in zelo pogosto zelo splošnih) podatkov iz ozadja, da bi diskurzivnemu segmentu zagotovil potrebno interpretativno avtonomijo in neodvisnost.

Na tem mestu lahko formuliramo prvo poskusno hipotezo:

$V$ sestavljenih veznikih KER PA in SICER PA uporabljeni PA omogoci referenco na neke vrste skupno, splošno ali implicitno vednost iz ozadja, na nek predhodni diskurzivni segment ali izven-diskurzivno situacijo z namenom, da bi dopolnil dani diskurzivni segment kot diskurzivno avtonomen in neodvisen. Medtem ko se KER PA večinoma nanaša na (možne) razloge, se SICER PA večinoma nanaša na (možna) pojasnila, ki so povezana s potekajočim diskurzom. Če sta uporabljena brez PA, KER in SICER takšne reference ne omogočata.

\section{Primer IZ TISKA 9}

Analizirajmo najprej članek Dragana Džurića z naslovom »Slovenija in demokracija«, ki je bil prvič objavljen v hrvaškem časopisu Vjesnik in ponatisnjen v slovenskem časopisu Delo, 22. junija, 1988.

\section{Slovenija in demokracija}

Slovenska javnost je v zadnjih tridesetih dneh doživela dva nova »šoka«. Potem ko so se maja pojavile govorice, da so v tej naši najsevernejši republiki pripravljali »vojaški udar«, se je junij začel z aretacijo Janeza Janše, Ivana Borštnerja in Davida Tasića. Publicista, zastavnika v JLA in enega od urednikov Mladine. Vse tri so priprli zaradi suma, da so izdali vojaško skrivnost. Kot je rečeno v uradnem sporočilu, so pri njih našli dele posameznih strogo zaupnih vojaških dokumentov. Ob vse bolj gromoglasnem sozvočju izjav in sporočil raznih združenj, odborov in forumov, so Janša, Borštner in Tasić iz pristojnosti republiškega sekretariata za notranje zadeve prešli »v roke « vojaškega

${ }^{9}$ Zaradi narave sestavljenih veznikov - kot smo jih opisali v zgornjih hipotezah - v analizi primerov iz časopisov navajamo vse članke v celoti in ne le odlomkov, kjer se pojavljata ker pa in sicer pa. 
tožilca. Gre namreč za vojaško skrivnost. Čeprav je šlo v prvem primeru zgolj za govorice, v drugem pa epiloga zgodbe za zdaj še nihče ne pozna, je bilo dejstvo, da so oba primera spretno združili, za nekatere dovolj, da v vsem tem vidijo jesen »slovenske pomladi« oziroma začetek konca demokratizacije. Ali niso to kljub vsemu nekoliko prenagljene ocene?

Kar zadeva primer Janša - s katerim so se pravzaprav začele aretacije in preiskave delovnih mest in stanovanj - so Mladina, Tribuna, Katedra in Radio Študent v »sporočilu javnosti « objavili, da gre za »nedopustno vmešavanje $v$ volilni postopek in grob pritisk na javnost «. Očitno je torej, da ima pripor Janše - na podlagi suma, da je zakrivil dejanje izdaje vojaške skrivnosti - hude politične implikacije. KER PAI gre za enega od kandidatov za prihodnjega predsednika ZSMS, nas vse to ne bi smelo presenetiti. Oglasil se je tudi sedanji predsednik slovenske mladine Tone Anderlič in v imenu svoje organizacije od republiškega ministra za notranje zadeve Tomaža Ertla zahteval uradno pojasnilo o priporu Janše, za katerega je, kot pravi, izvedel iz časopisov.

To zahtevo bi si dejansko lahko razlagali kot nedemokratično dejanje. Zakaj naj bi sekretariat za notranje zadeve, če je ravnal v skladu s svojimi zakonskimi pooblastili, mladinsko organizacijo obveščal drugače kot ostalo javnost? Ali to pomeni, da bi morali Janšo v primerjavi z ostalimi smrtniki obravnavati drugače? KERPA2 se kandidacijski postopek za volitve v mladinski organizaciji že približuje koncu - in zaradi tega postaja prvorazredni politični dogodek - je Anderličeva zahteva po svoje kljub vsemu upravičena. Tega pa prav gotovo ne bi mogli trditi za skupno izjavo mladinskih glasil, ki že vnaprej diskvalificira legalne organe. In to še preden so le-ti dokončali svoje delo.

$\mathrm{Na}$ informativnem traku se je potem po že ustaljenem slovenskem medijskem ritualu odvrtela serija izjav in sporočil javnosti.

Oseminosemdeset slovenskih kulturnih delavcev je podpisalo izjavo, v kateri zahtevajo, da se pojasni, kdo je sprožil postopek zoper Janšo. Isto zahteva tudi Društvo književnikov Slovenije, ki hkrati zahteva tudi to, da Janšo, Borštnerja in Tasića takoj izpustijo iz zapora. Ob tem poudarjajo, da so ogorčeni »zaradi postopkov, ki v Sloveniji ustvarjajo ozračje izrednega stanja «. Skrbi jih za ustavno ureditev in svobodo javne besede.

Upravni odbor Društva novinarjev Slovenije pa v svoji izjavi poudarja, da je »večina novinarjev Društva novinarjev Slovenije izrazila zaskrbljenost glede spoštovanja ustavnosti, zakonitosti, človekovih pravic in demokratizacije naše družbe «.

Zakaj tolikšno nezaupanje v zakonite organe? Čemu vsa ta vprašanja republiškemu sekretariatu za notranje zadeve, družbeno-političnim organizacijam 
in organom Slovenije zaradi »zaprtosti informacij«? Tomaž Ertl je daljšem intervjuju, ki so ga 1. junija objavili v Delu (op. uredništva: Verjetno je mišljen intervju, objavljen v Delu 8. junija.), povedal, da javnost redno obveščajo o tem, kako vodijo postopek. Javnosti so pojasnili, kako poteka postopek, kaj so v postopku odkrili in zakaj se je sekretariat za notranje zadeve odločil za pripor.

Očitno ni nikakršnega dvoma. Vse dokler ne bodo dokazali, koliko so vsi ti sumi utemeljeni - o tem bodo svoje povedali pristojni pravosodni organi - pa vsekakor nikogar ne bi smeli razglašati za krivca. Zakonitim organom je torej treba dopustiti, da ugotovijo tista prav dejstva.

Glede pripombe, da so informacije nepopolne, pa lahko rečemo le to, da pač ne morejo biti celovitejše in natančnejše, dokler ne bo končana preiskava.

Prav tako najbrž niso upravičeni očitki, da je šlo za nezakonito ravnanje. Protesti dela javnosti torej ne stojijo na trdnih nogah. Še zlasti zato, ker se prav ta zavzema za demokratičnost.

Če se namreč nekdo zavzema za demokratičnost, potem bi moral kot civilizacijski dosežek demokracije priznavati tudi pravno državo, ki pa jo je mogoče prepoznati po ustavi in zakonih. Poleg tega je treba ob svobodni javni besedi priznavati tudi pozitivne predpise. Tudi v primeru, če so ti pomanjkljivi, in sicer vse dokler teh predpisov ne spremenimo. Za to pa je pristojna zvezna oziroma republiška skupščina.

V nasprotju s tem pa so se najglasnejši zagovorniki demokracije ujeli prav v tisto past, proti kateri se bojujejo na javnem prizorišču, saj svoje mnenje vsiljujejo kot vrhunsko merilo. Tako kot nismo pripravljeni sprejeti dogmatika, ki nima posluha za raznovrstnost in bogastvo mnenj, tudi »demokrat«, ki bi izven z ustavo in zakoni določenih pravil pometel s površja zemlje vse tiste, ki ne mislijo tako kot on, ne more širiti prostora demokracije. Demokratična družba namreč ne pomeni, da v njej ni dogmatikov, tako kot tudi sicer noben družbenopolitični sistem ni črnobel.

V sporočilu predsedstva CK ZK Slovenije je rečeno, da ta organ »ne želi vplivati na potek postopka«. Kot je rečeno v sporočilu, so za vse odgovorni pristojni organi, ki so začeli in tudi sicer vodijo postopek.

Pravosodni organi bi torej morali samostojno - in seveda pošteno - do konca opraviti svoje delo. Vsekakor pa trenutnega izbruha »svobodnjaških zahtev«, $s$ katerimi posamezniki dejansko skušajo izvajati nekakšen pritisk na pravosodje, ni mogoče okarakterizirati zgolj kot pritisk na sodne in preiskovalne organe. Mnogi izmed njih v glavnem zahtevajo spoštovanje ustavnosti in zakonitosti, pa tudi korektno in čim popolnejše obveščanje javnosti. 
Dejstvo pa je, da bo moralo pravosodje v prihodnje računati s tem javnim hrupom, pa tudi z javnostjo, ki je vse bolj lačna popolnejših informacij. SICER $P A$ je to običajna cena, ki jo je treba plačati takrat, ko se odprejo demokratični ventili. O tem, da smo kljub vsemu dosegli višjo stopnjo demokratizacije, pa priča tudi dejstvo, da se ta primer vsak dan pojavlja v javnosti.

Če bi bili časi drugačni, bi o vsem skupaj objavili le skopo poročilo - ali pa še tega ne, piše v Vjesniku Dragan Djurić.

Če si podrobneje ogledamo sestavljena veznika ker pal in ker pa2, lahko opazimo, da se eksplicitno ne nanašata na noben del besedila. Namesto tega segata izven besedila in uvajata nekatere nove argumente: dejstvo, da je ob določenem času Janez Janša kandidiral za predsednika RK ZSMS, in dejstvo, da se je postopek izbora bližal koncu (v najboljšem primeru sta bili obe dejstvi del predhodne skupne vednosti). Ker pal in ker pa 2 v besedilo torej (implicitno) uvajata nove izjavljalce, nove izjavljalne položaje in nove glasove, ali če povemo to nekoliko bolj abstraktno in natančno, veznika uvajata nova stališča in dele informacij, ki eksplicitno in transparentno niso bili vključeni v besedilo. Da bi besedilu dali nujno koherenco (interpretativno avtonomijo in neodvisnost), moramo predpostavljati, da so stališča govorca (v našem primeru avtorja članka) posledica soočenja več izjavljalcev ali izjavljalnih položajev (ki so v članku le nakazani, a niso z njim neposredno povezani). Tovrstno strukturiranje v besedilu bomo, izhajajoč iz že predstavljenega Ducrotovega koncepta o polifoniji, imenovali večglasno, polifono strukturiranje.

Zaradi večje jasnosti ga na tem mestu vendarle nekoliko obnovimo. ${ }^{10}$ Koncept polifonije ne razlikuje le med avtorjem (kot hipotetično empirično entiteto) in govorcem (kot entiteto, ki spada v diskurz), temveč cepi govorca še na več izjavljalcev ali izjavljalnih položajev, ki so potemtakem povsem diskurzivne in znotrajjezikovne entitete. Govorec je odgovoren le za konkreten diskurzivni fragment, ali, če smo bolj natančni, za dejanje izjavljanja (kot dogodek pojavljanja danega diskurzivnega fragmenta). Znotraj tega diskurzivnega fragmenta govorec predstavlja več izjavljalcev v vlogi pobudnikov stališč, ki so izražena skozi in z diskurzivnim fragmentom, medtem ko njihovo soočenje, to je predstavitev različnih stališč, odseva kontekst, v katerem je bila izjava izrečena. Kot pojasnilo si na kratko oglejmo tole že znano izjavo:

\footnotetext{
${ }^{10}$ Polifonijo smo nazorno predstavili že v poglavjih Med argumentativnimi členki in polifonijo ter Kako napravimo kaj z besedami - polifoni način.
} 
(54) Ta ograja ni rdeča.

Govorec te izjave predstavlja dva izjavljalca:

- (I1), ki trdi, da je ograja rdeča (implicitno),

in

- (I2), ki zavrača njegovo trditev (eksplicitno).

Toda kako lahko razlikujemo med različnimi izjavljalci v okviru iste izjave? V primeru (54) nam to omogoča že samo dejstvo (ali »dejstvo《), da ograj, ki bi bile ne-rdeče, ne-rumene ali ne-rjave, sploh ni. Seveda obstajajo ograje, ki jih lahko opišemo kot ne-rdeče, ne-rumene ali ne-rjave, vendar nam ta podatek ne da prav nobene predstave o tem, kakšne barve ograja $\mathrm{v}$ resnici je (ali je rdeča, rumena ali rjava). Zato nekdo, ki trdi, da X ni ..., zelo verjetno ugovarja nekomu, ki trdi nasprotno, da namreč X je ... ${ }^{11}$

Vrnimo se spet k ker pal. Da bi ga lahko analizirali polifono, moramo razcepiti govorca (avtorja članka) na dva izjavljalca (izjavljalna položaja):

- I1 predstavi neko dejstvo D1 (aretacija državljana), ki ima nenavadno lastnost L1 (hude politične implikacije);

- I2 nasprotuje L1 (ki jo je predstavil I1) tako, da predstavi neko novo dejstvo D2 (to je državljan, ki se ukvarja s politiko), s katerim se očitno sklicuje na neki topos kot Bolj ko se nekdo ukvarja s politiko, boljpolitično so interpretirana njegova/njena dejanja. Govorec $\mathrm{G}$, avtor članka, se pridruži I2 v njegovem/njenem nasprotovanju.

Še zanimivejša je interpretacija (ali možnost interpretacije) ker pa2. Temeljila bi lahko ne le na soočenju dveh izjavljalcev, temveč tudi na soočenju dveh topoi (pojmovanih kot posplošene (in poenostavljene) oblike implicitne vednosti iz ozadja), in sicer:

- I3 predstavi neko dejstvo D3 (upoštevati je treba demokratične metode), z lastnostjo L3 (enak način obravnave za vse), s čimer se sklicuje na neki topos kot Bolj ko so demokratični zakoni, bolj strogo jih je treba upoštevati;

- I4 se strinja z I3 in se povrhu tega sklicuje še na močnejšo različico prejšnjega toposa, Bolj ko so razmere zaostrene, bolj demokratične metode je treba uporabljati. In govorec (avtor članka) se pridruži tej zadnji argumentaciji.

Posebej zanimiva (zlasti za dodatno osvetlitev narave topoi v Ducrotovi teoriji argumentacije v jeziku in argumentih, ki na njih temeljijo) pa je možna interpretacija sicer pa. Pokaže namreč, da lahko isti topos pred-

${ }^{11}$ To seveda ne pomeni, da trdilne izjave ne morejo biti polifone: ko nekdo pravi Ta ograja je rde$\check{c} a$, lahko s tem zatrjuje, kar je nekdo drug zanikal. 
stavlja izhodišče za različne, celo nasprotne sklepe, da se lahko isti topos križa z različnimi izjavljalnimi položaji. Sicer pa lahko razcepimo na govorca in dva izjavljalca:

- I5 predstavi neko dejstvo D1' (isto dejstvo kot v primeru ker pal, to je aretacija državljana) in mu pripisuje lastnost L1' (veliko vznemirjenje javnosti), ki pa je drugačna od tiste, ki jo uporabi Il (v primeru kerpal).

- I6 nasprotuje I5 z dejstvom D3“ (ki je enako kot v primeru ker pa2, namreč da je treba upoštevati demokratične metode) in mu pripisuje lastnost C3“ (svoboda informacij), ki se razlikuje od tiste, ki jo I3 uporabi v ker pa2. $\mathrm{S}$ tem se I6 sklicuje na nek topos kot Bolj ko so zaostrene razmere, bolj demokratične metode je treba uporabljati (topos, ki ga je uporabil I4, ko je nasprotoval/zavrnil I3). Povedano z drugimi besedami, I6 uporablja stopnjevanje (intenzifikacijo), da bi nasprotoval/zavrnil argumentacijo I3. ${ }^{12}$

\section{Hipoteza}

V luči tega, kar smo povedali, lahko sedaj predlagamo našo drugo poskusno hipotezo:

Veznik PA - kadar se uporablja v sestavljenih veznikih KER PA in SICER PA - ima vlogo neke vrste anaforićnega elementa, ki s tem, ko omogoca referenco na neke vrste skupno, splošno ali implicitno vednost iz ozadja, na nek predhoden diskurzivni segment ali izven-diskurzivno situacijo, razkriva polifono strukturo danega diskurzivnega segmenta in mu tako zagotavlja potrebno interpretativno neodvisnost in avtonomijo.

V bolj splošnem smislu bi za veznik pa kot (diskurzivni-argumentativni) modifikator drugih veznikov lahko rekli, da ima eno nezaznamovano (a) in dve zaznamovani $(b-c)$ funkciji:

a) poudarja vlogo (pomen in funkcijo) predhodnega veznika kot $\mathrm{v}$ pravkar pa, bojda pa, kakor pa, vendarpa;

b) zahteva izbiro argumenta, čigar (argumentativna) usmerjenost je nasprotna usmerjenosti argumenta, ki stoji pred veznikom, ki ga modificira $p a$;

c) nasprotuje argumentu, ki stoji pred veznikom, ki ga modificira $p a$, tako da omogoča referenco na nek(o) 1) predhoden diskurzivni segment ali izven-diskurzivno situacijo, 2) skupno, splošno ali implicitno vednost iz ozadja.

\footnotetext{
${ }^{12} \mathrm{Z}$ vidika polifonije je notranja dinamika besedila še nekoliko bolj zapletena: s predstavitvijo dejstva D1', I5 (vsaj implicitno) nasprotuje I1 s stališča, da I5 pripisuje istemu dejstvu drugo lastnost. Na drugi strani I6 (vsaj implicitno) nasprotuje I3 s stališča, da I6 pripisuje drugo lastnost dejstvu D3'.
} 
$\mathrm{V}$ tem pogledu bi zaznamovane rabe $p a^{13}$ še najustrezneje opisali s sintagmo sprevračevalec argumentativnega pričakovanja (pričakovanje argumenta, ki bi sledil iz potekajočega diskurza, je preobrnjeno z referenco na neke vrste skupno, splošno ali implicitno vednost iz ozadja, na nek predhodni diskurzivni segment ali izvendiskurzivno situacijo). To lahko ponazorimo na sledeč način:

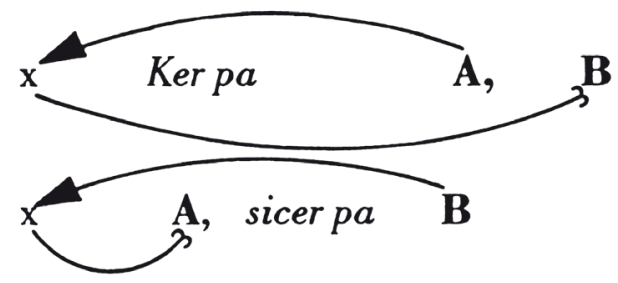

Takoj se pojavita dve vprašanji: kakšna je vloga veznikov ker in sicer, kadar se rabita samostojno in kadar se rabita skupaj s pa? Ali je delovanje sicer in ker, kadar sta rabljena samostojno, res tako drugačno od tistega skupaj spa?

Po SSKJ ker služi za:

I - za izražanje dejstva, da je vsebina odvisnega stavka vzrok dogajanju $v$ nadrednem:

(55) Ker resnice ni smel povedati, je rajši molčal.

(56) Nanj sem se obrnil zato, ker vem, da je pošten.

II - za vzročno pojasnjevanje prejpovedanega:

(57) Skrb je odveč, ker delavci so zanesljivi.

$\mathrm{Na}$ drugi strani, se sicer uporablja za:

I - za izražanje posledice, če bi se prejpovedano ne uresničilo:

(58) Brž pomagaj, sicer bo prepozno.

II - za uvajanje omejevane trditve, kiji nasprotuje trditev v drugem stavku:

(59) Sicer je še mlad in neizkušen, vendar zelo spreten.

III - za dopolnjevanje, pojasnjevanje prejpovedanega:

(60) Kmalu se bodo pripeljali, in sicer iz te smeri.

IV - izraža razmere ali stanje ob drugih, drugačnih priložnostih:

(61) Zakaj mi ni nič povedala, saj je sicer tako odkritosrčna.

(62) Danes so mu vsi zoprni, čeprav sicer z vsemi dobro sodeluje.

${ }^{13}$ Nezaznamovane rabe pa ostajajo izven področja obravnave pričujočega besedila. 
V-izraža rablo omejitev, pridržek:

(63) To je sicer lepo, je pa zame predrago.

VI - izraža ugotovitev, spoznanje resničnega stanja:

(64) Vsi mu morajo streči. Sicer pa si samo domišlja, da je bolan.

(65) Lahko greš z mano. Sicer pa se rajši vidim, da ostaneš doma.

VII - izraža splošno veljavnost povedanega:

(66) Njihovo ravnanje ljudem ni bilo všeč. Sicer pa so delali po že preizkušenih metodah.

(67) Od vseh zahteva natančnost. Sicer pa je strog tudi do samega sebe.

VII - poudarja zanikano trditev, ugotovitev:

(68) Ne bomo te več silili. Sicer pa ne misli, da je tako hudo.

(69) Kdo tako kriči? Sicer pa mi to nič mar.

(70) Tega niste nikoli omenili. Sicer pa pustimo to zdaj.

Za potrebe pričujočega članka se zdijo še posebej zanimive rabe veznikov ker (55)-(56) in sicer (64)-(70). Primera (55) in (56) kažeta, da definicije v SSKJ podajajo zavajajoča pojasnila. Četudi bi v teh primerih 'vsebino odvisnega stavka' bilo mogoče interpretirati kot 'vzrok dogajanja v nadrednem stavku', tega ne bi mogli in smeli razumeti v časovno vzročnem smislu. Ne bi namreč mogli reči, da je vršilec dejanja v (55) obmolknil, ker ni smel povedati resnice, ali natančneje, da je bilo njegovo nenadno spoznanje, da ne sme povedati resnice, vzrok, da je utihnil. Prej bi lahko rekli, da je 'vsebina odvisnega stavka' interpretacija povezanih dogodkov v nadrednem stavku. Vršilec dejanja bi, denimo, lahko obmolknil že pred ali po tem, ko bi izvedel za 'vsebino nadrednega stavka'. Še več, opraviti imamo z domnevno resničnim dogodkom, $s$ katerim sta povezana dva sistema verjetij: prvi pripada molčečemu vršilcu dejanja, drugi govorcu. Poslušalcem/ bralcem je na voljo le govorčeva resnica, in sicer, da je vršilec dejanja bil tiho, ker ni smel povedati resnice. Še vedno pa ne vemo, ali bi se molčeči vršilec dejanja strinjal z govorčevo interpretacijo (ne glede na dejansko stanje stvari). 'Vsebino odvisnega stavka' smemo tako razumeti le kot govorčevo interpretacijo molka vršilca dejanja, ne pa (nujno) tudi kot vzrok zanj.

Primer (56) je mogoče utemeljiti na podoben način: malo verjetno je, da bi lahko bila 'vsebina odvisnega stavka' (moja vednost o tem, da je subjekt razprave pošten) vzrok za z njo povezan dogodek v nadrednem stavku (dejstvo, da sem se nanj obrnil). Veliko verjetnejša je možnost je, da gre za njegovo interpretacijo: verjetno sem se nanj obrnil, ker sem vedel, da je (običajno) pošten, toda razlog, da sem se nanj obrnil prav ob tej priložnosti 
ni bila (ali ni bila zgolj) moja vednost o njegovi pregovorni poštenosti, ampak dejstvo, da sem od njega nekaj hotel. In ker sem vedel, da je pošten, sem se obrnil nanj (in ne na nekoga drugega). Kot v primeru (55) imamo tudi tukaj (le) eno dejstvo (govorec se je obrnil na subjekt razprave) in dva (različna) sistema verjetij: govorčev in objektov (o čigar interpretaciji dejanskega dogodka (zakaj se je govorec zares obrnil na osebo, o kateri govori) nimamo nobenih informacij).

Dodaten argument v podporo hipotezi, da je 'vsebina odvisnega stav$\mathrm{ka}$ ' le interpretacija in nikakor vzrok za dogodek v nadrednem stavku, je v slovenščini izbira glagolskih časov, preteklika v nadrednem stavku ('nanj sem se obrnil') in sedanjika v odvisnem stavku ("ker (because) vem, da je pošten'). Neko sedanje dejstvo vsekakor ne more biti vzrok za nekaj, kar se je zgodilo v preteklosti. Ker pa je sedanjik uporabljen zgolj kot navezava na pretekli dogodek, to pomeni le, da govorec v primeru (56) pojasnjuje kriterij za izbiro naslovnika svojega dejanja, nikakor pa ga ne povzroča.

Če si ponovno ogledamo tabelo, ki predstavlja delovanje ker pa (in sicerpa), lahko sklepamo, da je X tisti, ki bi lahko bil vzrok (in posledično argument) za z njim povezan dogodek v nadrednem stavku. Na drugi strani smo lahko videli, da je 'vsebina odvisnega stavka', ki jo uvaja ker, le interpretacija nadrednega stavka ali ena od njegovih (možnih) interpretacij. In precej verjetno je, da bi X moral biti povsem mentalne narave (v primeru (55) je, denimo, moja vednost/prepričanje/strah ... razlog, zakaj ni mogel povedati resnice; v (56) bil lahko bila moja vednost/prepričanje/upanje ..., da je pošten). Za pričujočo analizo je pomembna predvsem možnost, da je šlo za neko vednost/prepričanje/strah itd., ki je obstajalo, še preden je dotični diskurzivni segment bil izgovorjen in da je bila ta vednost/prepričanje/strah uporabljena kot posredni razlog (argument) za pojav povezanega dogodka v nadrednem stavku.

$\mathrm{V}$ primeru veznika sicer, ki se v povezavi s pa pojavlja veliko pogosteje kot ker, nekatera pojasnila v SSKJ eksplicitno kažejo, da diskurzivni segment, ki ga uvaja sicer pa, podpira neko predhodno dejstvo, ki je povezano z danim diskurzivnim segmentom. Oglejmo si, na primer:

(64) Vsi mu morajo streči. $\leftarrow$ Sicer pa si samo domišlja, da je bolan.

Če pa izpustimo, izjava napeljuje $\mathrm{k}$ nenavadnim, celo nesmiselnim implikaturam in možnim sklepom (v oglatih oklepajih):

(64) Vsi mu morajo streči. $\leftarrow$ Sicer si samo domišlja, da je bolan. [Če mu vsi ne strežejo, si samo domišlja, da je bolan (čeprav v resnici ni). 
$\rightarrow$ Če mu vsi strežejo, je (v resnici) bolan (sicer si samo domišlja, da je bolan).]

$\mathrm{Na}$ drugi strani izpuščanje pa $\mathrm{v}$ primerih (66) in (68) stavke oropa njihove interpretativne avtonomije in neodvisnosti, $s$ čimer postanejo kontekstualno povsem neumestljivi, kot kažeta primera $\left(66^{\circ}\right)$ in $\left(68^{\prime}\right)$ :

(66) Njihovo ravnanje ljudem ni bilo všeč. $\leftarrow$ Sicer pa so delali po že preizkušenih metodah.

(66) Njihovo ravnanje ljudem ni bilo všeč. $\leftarrow$ Sicer so delali po že preizkušenih metodah

(68) Ne bomo te več silili. $\leftarrow$ Sicer pa ne misli, da je tako hudo.

(68') Ne bomo te več silili. $\leftarrow$ Sicer ne misli, da je tako hudo.

Isti problem smo obravnavali že v zvezi s primeri (51')-(53'), toda zanimivo je, da primera $\left(66^{\prime}\right)$ in $\left(68^{\prime}\right)$ pridobita nazaj svojo interpretativno avtonomijo in neodvisnost, če ob pa izpustimo tudi sicer:

$\left(66^{\prime \prime}\right)$ Njihovo ravnanje ljudem ni bilo všeč. $\leftarrow$ Delali so po že preizkušenih metodah.

(68") Ne bomo te več silili. $\leftarrow$ Ne misli, da je tako hudo.

Takšna substitutivna analiza nas vodi do sklepa, da je sestavljeni veznik sicer pa in ne sicer sam tisti, na katerega se morajo nanašati definicije VIVIII v SSKJ.

Toda tovrstna analiza postavlja tudi neprijetno vprašanje: če je veznik sicer pa mogoče izpustiti, ne da bi to vplivalo na avtonomijo in neodvisnost analiziranih argumentativnih nizov, zakaj ga potem sploh uporabljati? Moja hipoteza je, da se uporablja z namenom, da bi argumentu dal kompleksnost - ali vsaj vtis kompleksnosti - da bi preoblikoval (običajno) linearno argumentativno strukturo, $\mathrm{A} \rightarrow \mathrm{S}, \mathrm{S} \leftarrow \mathrm{A}$, v kompleksno, večplastno strukturo - natanko s sklicevanjem na neko skupno, splošno ali implicitno vednost iz ozadja, na neki predhodni diskurzivni segment ali izven-diskurzivno situacijo.

\section{ŠE NEKAJ PRIMEROV IZ TISKA}

Preverimo sedaj zgornjo hipotezo na nekaj člankih, ki smo jih, ponovno, izbrali iz glavnega slovenskega dnevnika Delo. 


\section{V tej družbi očitno nismo zaželeni ${ }^{14}$}

\section{Tiskovna konferenca Stranke za enakopravnost občanov - Pri- tiski na stranko?}

»Ker je bila stranka za enakopravnost občanov na zadnjih volitvah okradena, z oblastjo ne more komunicirati drugače kot prek sredstev javnega obveščanja«, je najprej povedal predsednik te stranke Dragiša Marojević na današnji tiskovni konferenci. Namenjena je bila predstavitvi strankinih stališč do osnutka dopolnil k republiški ustavi, o katerih teče javna razprava. Poslali so jih ustavni komisiji, vendar verjetno ne bodo predstavljena delegatom republiške skupščine. Govorili so tudi o pritiskih na njihovo stranko oziroma o političnem ekscesu republiškega sekretariata za notranje zadeve, do katerega je prišlo po objavi njihovega sporočila za javnost v zvezi z dogodki v Kninu. »Ker dejstva in realnost pričajo, da je Republika Slovenija še vedno v sestavi SFRJ, smo prepričani, da bi, če bi bila sprejeta ustavna dopolnila, direktno onemogočili nadaljnji demokratični dialog za rešitev politične krize v Jugoslaviji «, meni Stranka za enakopravnost občanov. Na tiskovni konferenci so poudarili, da je nevzdržna direktna kolizija z veljavno ustavno ureditvijo v SFRJ in spremljajočimi zakonskimi določbami. To ni nič drugega kot uničevanje pravne države. Še posebej skrb zbujajoče pa je, da so predložene rešitve v nasprotju z 235. členom ustave SFRJ, ki govori o suverenosti države Jugoslavije in pravicah njenih prebivalcev, da to suverenost branijo. To lahko povzroči zelo hude posledice in vnese nemir med prebivalstvo, so poudarili na tiskovni konferenci.

Kazenske prijave temeljnemu javnemu tožilstvu in prijava pri pristojnem občinskem organu za registracijo političnih strank zaradi »spornega besedila $v$ strankinem sporočilu za javnost v zvezi s kninskimi dogodki nam samo dokazujeta, da v tej demokratični družbi nismo zaželeni, pa je dejal Dragiša Marojević. Najbolj čudno pa je to, da verbalni delikt ponovno oživljajo vsi tisti demokrati, ki so se prej soglasno zavzemali za njegovo odpravo. Dragiča Marojević je med drugim tudi povedal, da je po objavi strankinega sporočila prejel v seriji petnajst anonimnih pisem z grobimižalitvami, za katera v stranki sumijo, da so prišla s policije.

SICER PA stranka meni, da so človekove pravice najbolj kršene v Sloveniji.

Sklepni stavek besedila, ko ga obravnavamo v povezavi z drugimi izjavami na tiskovni konferenci, se zdi precej neobičajen $\mathrm{v}$ tem, da je vodja

${ }^{14}$ Mihaela Žitko, Delo (7. september 1990). 
stranke navajal primere, ki jih je imel za kršitve človekovih pravic v Sloveniji. Pričakovani sklep bi se lahko glasil zgolj takole:

(71) Stranka torej meni, da so človekove pravice najbolj kršene prav v Sloveniji. ali (morda):

(72) Stranka meni, da so človekove pravice torej najbolj kršene prav v Sloveniji. toda nikakor:

(73) Sicer pa stranka meni, da so človekove pravice najbolj kršene prav v Sloveniji.

Zakaj? Ker (kot smo že videli v analizi sicer pa) raba sestavljenega veznika sicer pa implicira, da 1) govorec namerava spremeniti temo ali prehaja $\mathrm{k}$ drugi misli, ali 2) govorec namerava uporabiti neko že (ali splošno) znano dejstvo, s katerim bo podprl ali okrepil to, kar je izjavil.

Na prvi pogled avtor ne počne ničesar od pravkar navedenega. Natančneje: zakaj bi kdo oblikoval natančen seznam kršitev človekovih pravic $\mathrm{v}$ Sloveniji še z drugo trditvijo, da so bile človekove pravice najbolj kršene prav v Sloveniji - s trditvijo, ki je očitno ne moremo razumeti kot sklep, ki povzema to, kar je bilo predhodno povedano, saj jo uvaja sestavljeni veznik sicerpa?

Ideja se zdi neobičajna, morda celo protislovna, le dokler predpostavljamo, da je vpleten (t. j. avtorica članka) le en sam govorec (izjavljalni položaj, stališče). Celo površen bralec bi lahko opazil, da avtorica preprosto podaja Marojevićeve besede - vse do zadnjega stavka. Toda, kdo je govorec v zadnjem stavku: avtorica ali nekdo drug? Zadnji stavek ne bi predstavljal nobene ko(n)tekstualne težave, če bi ga parafrazirali kot:

(74) Sicer pa, kot že vemo, stranka meni, da so človekove pravice najbolj kršene prav v Sloveniji.

Povedano z drugimi besedami, vpeljava parafraze kot že vemo, ki očitno zaznamuje sklicevanje na neko implicitno skupno vednost, omogoča lažje razločevanje več izjavljalcev (izjavljalnih položajev ali stališč) v članku, ki ga podpisuje le ena novinarka. $V$ danem besedilu lahko identificiramo tri:

- I1 'razkrije‘ kršitev človekovih pravic v Sloveniji ('empirično', na ravni pojavitve oseb v besedilu bi to lahko bil Dragiša Marojević);

- I2 (morda z navajanjem dokazov o dejanskem spoštovanju človekovih pravic v Sloveniji, ali s pomočjo primerjave stanja človekovih pravic v Slo- 
veniji s stanjem v drugih bivših jugoslovanskih republikah, ali kako drugače) nasprotuje I1 (na ravni pojavitve oseb v besedilu I 2 nima empiričnega predstavnika; njegovo nasprotovanje I1 (in dejstvo, da je izjavljalni položaj I2 neločljivo povezan z besedilom) postane očitno le ob (in zaradi) pojavitvi I3);

- I3 povzame razpravo s sklicevanjem na neko predhodno, splošno ali implicitno skupno vednost ( $\mathrm{v}$ našem primeru vednost o 'razkritjih' oziroma načinu argumentacije I2), ki slabi moč argumenta, ki ga je predstavil I1 (zanimivo je, da bi I3 lahko predstavljal avtorico, le da tokrat ne privzema vloge poročevalke, temveč raje vlogo komentatorke; v empiričnem smislu ima torej v danem diskurzu ena in ista oseba dve ločeni izjavljalni vlogi).

Seveda pa struktura sestavljenega veznika sicer pa ni nujno tako kompleksna. Včasih se celo zdi, da mu sploh ni mogoče pripisati polifone strukture. To ilustrirajo članki v nadaljevanju.

\section{Žarek upanja za zdravstvo ${ }^{15}$}

\section{Slovenska vlada išče pot iz zagate $\mathrm{v}$ zdravstvu - V javnih prosto- rih poslej ne bo več Titovih slik}

Kaj storiti s Titovimi slikami in kipi v javnih prostorih? Ker to niso državni simboli in ker doslej ni bilo nobenega predpisa, ki bi veleval, da Titove slike ali kipi morajo biti, je slovenska vlada danes na svoji seji menila, da je te slike ali kipe mogoče odstraniti.

To ni odlok, je zgolj priporočilo, ki seveda velja le za javne, ne pa tudi za zasebne prostore. Vlada ob tem svetuje kulturno ravnanje, hkrati pa priporoča dogovor z muzeji ali z drugimi kulturnimi inštitucijami, če gre za dela umetniške vrednosti.

Slovenska vlada je o tej temi razpravljala v zvezi s pobudo vojvodinske skupščine, ki je zvezni skupščini predlagala, naj razveljavi zakon o rabi imena in podobe Josipa Broza Tita, ki je bil sprejet v začetku osemdesetih let. Izvršni svet podpira vojvodinsko pobudo, o tej temi pa so obširneje spregovorili tudi zato, ker ljudje menda pogosto sprašujejo, kaj naj storijo s Titovimi slikami v šolah in drugih javnih ustanovah.

SICER PA so na tiskovni konferenci po seji vlade danes največ časa odmerili zagatam slovenskega zdravstva. Za normalno delo bi slovensko zdravstvo do konca leta potrebovalo 12 milijard dinarjev. Po rebalansu republiškega proračuna je na razpolago samo 8,9 milijard dinarjev. Zdravstveni zavodi so iz-

${ }^{15}$ Delo (21. september 1990). 
računali, da bi za najbolj nujno poslovanje, pravzaprav za preživetje, potrebovali 10,7 milijarde dinarjev. Kako do te razlike, je novinarjem po seji vlade poskušal razložiti dr. Tone Košir, namestnik republiške ministrice za zdravstvo.

Ukrepov je več. Eden takih je povečanje participacij, ki se pred 4. avgustom kar nekaj časa niso zvišale. Poleg tega je IS povečal akontacije, namenjene za pokritje materialnih stroškov in tudi za plače, vendar samo za zdravstvene organizacije, ki so v najtežjem položaju. Nekatere zdravstvene organizacije so oproščene tudi plačila republiških prispevkov in rezultatov dela.

Dr. Tone Košir je opozoril, da je zdaj že skrajni čas za sprejetje nove zakonodaje na področju zdravstva, zdravstvenega varstva in zdravstvenega zavarovanja. Prve teze in osnutki novih zakonov naj bi bili nared že do konca septembra. Še pred sprejetjem novih zakonov pa naj bi spremenili 20. člen zakona o zdravstvenem varstvu, s katerim naj bi razširili krog tistih, ki morajo plačevati participacije, razmišljajo pa tudi o hitrejši uvedbi zasebnega dela (zasebne prakse) v zdravstvu. To bi bilo mogoče storiti s sprejetjem amandmaja $\mathrm{k}$ sedanjemu zakonu.

Zdi se, da v zgornjem besedilu veznik sicer pa deluje v skladu z eno od definicij veznika sicer $v$ SSKJ, ki opisuje sicer zgolj v smislu indikatorja prehoda $\mathrm{k}$ drugi misli. Toda, ali gre res le za prehod $\mathrm{k}$ drugi misli? Preverimo tole $\mathrm{z}$ zamenjavo sicer pa, kot je uporabljen v članku, z drugim veznikom, ki navadno zaznamuje prehod $\mathrm{k}$ drugi misli, to je poleg tega:

(75) Sicer pa so na tiskovni konferenci po današnjem zasedanju največ časa odmerili zagatam slovenskega zdravstva.

(76) Poleg tega so na tiskovni konferenci po današnjem zasedanju največ časa odmerili zagatam slovenskega zdravstva.

Medtem ko poleg tega eksplicitno napeljuje na to, da gre v besedilu (vsaj) za dve temi, sicer pa za tak eksplicitni sklep ne ponuja nobenega indica. Če si ogledamo obliko in zgradbo članka, lahko opazimo, da se sicer pa (ali zamenjava poleg tega) nahaja nekako na polovici besedila, ko se ena tematika prevesi v drugo. To dejstvo bi (na zelo površinski ravni) lahko govorilo v prid teze, da gre le za prehod k drugi misli.

Toda, poglejmo si pobliže veznik poleg tega. Izhajajoč iz preproste aritmetične logike, bi lahko trdili, da 'največ časa' lahko odmerimo le eni stvari. Če so na tiskovni konferenci največ časa namenili zagatam slovenskega zdravstva, potem odstranjevanju Titovih slik pač niso mogli nameniti enake količine pozornosti in časa: če so največ časa namenili odstranjevanju Titovih slik, ga niso mogli največ nameniti zagatam slovenskega zdravstva, 
če pa so ga največ namenili zagatam slovenskega zdravstva, ga niso mogli največ nameniti odstranjevanju Titovih slik.

Ta bolj kot ne trivialna stvar je sporna le, če uvedemo veznikpoleg tega, ki je do (pomembnosti) vsebin, ki ju povezuje, nevtralen. In prav v tem se razlikuje od sicer pa. Iz prejšnjega primera (prvo besedilo) smo jasno videli, da sicer pa ne zaznamuje le prehoda k neki drugi vsebini ( $k$ eni od vsebin, obravnavanih v besedilu, $\mathrm{k}$ vsebini med vsebinami itd.), temveč tudi $\mathrm{k}$ zelo specifični vsebini, k tisti, ki predstavlja glavno temo v besedilu. Sicer pa namreč nedvoumno zaznamuje nek drugi izjavljalni položaj od tistega, ki je do njegovega nastopa imel besedo - izjavljalni položaj, ki ga bo v »površinski strukturi« prevzel in povzel tudi govorec (avtor).

Ustrezna analiza sicer pa $\mathrm{v}$ drugem besedilu mora zato govorca razcepiti v dva izjavljalca:

- I1 predstavlja neko dejstvo D1 (odstranjevanje Titovih slik, kar pa sploh ni pomembno; lahko bi šlo dobesedno za karkoli);

- I2 poudarja drugo dejstvo D2 kot pomembnejše (ki je prav tako, naj še enkrat poudarimo, lahko karkoli; tisto, kar ga v danem besedilu dela pomembnejšega, je prav dejstvo, da ga uvaja veznik sicer pa) in z I2 se staplja (ali sprejema stališče) tudi govorec $\mathrm{G}$.

Toda če je ta analiza ustrezna, kako naj potem pojasnimo sicer pa v sledečem primeru?

\section{Misijonar zdravil bolne ${ }^{16}$}

Seminar »Evangelizacija $2000 \ll v$ Ljubljani, kjer naj bi p. Emilian Tardif čudežno zdravil bolne, je privabil dvajset tisoč ljudi.

»ezus je tu med nami in zdravi bolne. Nekaterim med vami bodo izginile bolečine v ramenih in kolenih. Dvignite roke, če ste ozdraveli«, je po molitvi začel zdravljenje p. Emilian Tardif, misijonar iz Dominikanske republike, sicer pripadnik karizmatične skupine Prenova v Duhu.

Med tisočimi na stadionu v Spodnji Ššski v Ljubljani je zavladala tišina. »Ne

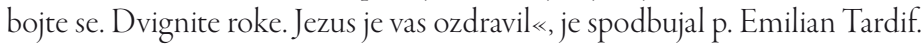
Nenadoma je nekdo dvignil roko, drugi pa je pomahal z robčkom. In potem še neka starejša ženica. Stadion je postal nemiren. »Hvala bogu. Gospod je velik«, je zanosno zaklical p. Emilian Tardif, udeleženci seminarja pa so začeli navdušeno ploskati. Nastala je nepopisna evforija.

${ }^{16}$ Delo (3. september 1990). 
Približno tako je minuli konec tedna zdravil bolne p. Emilian Tardif na tridnevnem brezhibno pripravljenem seminarju »Evangelizacija 2000 « na stadionu v Spodnji Šiški v Ljubljani. Čudežne ozdravitve, ki jih je omenjeni pater opisoval med svojimi govori, so se običajno zgodile po verskem obredu in po njegovi molitvi za bolne v nekem nerazumljivem jeziku, za katerega je p. Emilian Tardif dejal, da ga tudi sam ne razume. To je pač božji dar, skozi katerega dobi, po njegovih besedah, » preroštvo ozdravljenja «. Sicer pa naj bi te dni nekateri ozdraveli v ramenih, kolenih, hrbtenici, ušesih, drugi pa naj bi čez nekaj tednov ozdraveli od rakastega obolenja.

Tako je na primer Zdravko Kovačič iz Bugojna dejal, da je imel že dvajset let težave s hrbtenico. »Na seminarju sem molil za neko deklico, nenadoma pa sem začutil mravljince v hrbtenici. Bolečine so nato izginile. Vedel sem, da me je Jezus ozdravil «, nam je pripovedoval o svoji ozdravitvi Zdravko Kovačič. Nekaj podobnega naj bi se zgodilo tudi z Vojko Mihačič iz Izole in Fani Žele z Reke, ki sta čakali pred ambulanto, da bi čudežni ozdravitvi potrdili še zdravniki.

In kaj pravijo zdravniki? Dr. Janez Zajc, specialist za fizikalno medicino in rehabilitacijo na Kliničnem centru v Ljubljani, ki je na seminar prišel na povabilo prijatelja p. Marjana Šefa iz župnijskega urada sv. Jakoba v Ljubljani (enega izmed prirediteljev), je na sobotni tiskovni konferenci za novinarje dejal, da so pregledali 18 čudežno ozdravljenih. Pri štirih so ugotovili, da je gibljivost v ramenih oziroma kolenih zelo dobra, čeprav so ozdravljeni pričevali, da so imeli pred seminarjem močne bolečine. »To še ne pomeni, da so resnično ozdraveli na seminarju. Najprej moramo namreč primerjati njihovo prejšnjo bolezen s sedanjim stanjem «, je še dejal dr. Janez Zajc. SICER PA je na seminarju evangelizacije bilo kar 15 zdravnikov in 35 medicinskih sester.

Če naj dani sicer pa interpretiramo le kot prehod $\mathrm{k}$ drugi misli, bi pričakovali, da ga bo brez težav mogoče nadomestiti ali parafrazirati s poleg tega ali celo s tudi. Na primer:

(77) Na seminarju je bilo tudi (also) 15 zdravnikov in 35 medicinskih sester.

Takšna parafraza pa očitno ni legitimna, saj ne dopušča implikatur (ali možnih sklepov), $\mathrm{k}$ katerim običajno napeljuje različica $\mathrm{z}$ veznikom sicer pa:

(78) Sicer pa je na seminarju evangelizacije bilo kar 15 zdravnikov in 35 medicinskih sester. $\rightarrow[$ Vsi (ti) skupaj bodo pač lahko ugotovili, kaj se je v resnici zgodilo.]

ali 
$\left(78^{\circ}\right)$ Sicer pa je na seminarju evangelizacije bilo kar 15 zdravnikov in 35 medicinskih sester. $\rightarrow$ [Morda je prav njihova prisotnost pripomogla $\mathrm{k}$ (čudežnemu?) ozdravljenju.]

Zamenjava veznika sicer pa s poleg tega ali z veznikom tudi naredi iz sklepnega stavka nekakšno slepo črevo besedila, nekakšen pristavek po sili, ki na predhodno besedilo nima nikakršnega vpliva. Tega pa ne bi mogli reči za različico s sicer pa, ki celotnemu besedilu - nekako za nazaj - podeli specifično, odprto polifono strukturo. Glede na implikaturi v primerih (78) in (78'), moramo razlikovati med tremi izjavljalci/izjavljalnimi položaji, od katerih sta prva dva skupna obema implikaturama:

- I1 predstavi neko dejstvo D kot čudežno (ozdravljenje več ljudi);

- I2 predstavi to isto dejstvo D kot dvoumno (glede na njegove vzroke);

- (I3) variira, glede na implikaturo, ki jo izberemo.

Če smo se odločili za implikaturo v (78), I3 ne podpira niti stališča I1 niti stališča I2, temveč zavzame nevtralen položaj: nadaljnje preiskave bodo pokazale, ali ima prav I1 ali I2 (kar, implicitno, seveda pomeni, da daje prav I2).

Če pa smo se odločili za implikaturo v (78'), I3 niha med stališčema I1 in I2: če je prav prisotnost številnih zdravnikov pripomogla k ozdravljenju, I3 očitno podpre stališče I2. Toda če je k ozdravljenju pripomogla le prisotnost zdravnikov, ne pa njihova zdravilna dejavnost, gre očitno res za čudežno ozdravljenje, kar pomeni, da I3 podpre stališče I1.

Za katero implikaturo se bomo odločili, je seveda odvisno od toposa (zgoščenega ozadja, implicitne in/ali skupne vednosti), ki ga bomo uporabili: isti topos (npr. Več ljudi več ve) namreč lahko podpre obe, sicer različni, implikaturi. To ne pomeni le, da se je G(ovorec), ki se staplja (ali identificira) z I3, zatekel po pomoč k neki splošni, dani (družbeni, poklicni itd.) skupnosti skupni splošni vednosti, temveč da imamo opraviti s tako splošno strukturo, da je z njo mogoče (v različnih skupnostih oziroma različnih sistemih verovanj) podpreti različne argumente za isti sklep. Poteza G(ovorca) je torej na moč prefinjena: $s$ tem, ko ohranja dva mogoča I3, nam, po eni strani kar sam izlušči skeletno strukturo svojega sklepanja, po drugi strani pa nam da istočasno videti, da je prav ta preprosta, skeletna struktura (in prav zato, ker je skeletna) tista, ki dopušča raznovrstnost možnih sklepov, in s tem daje besedilu večglasno - polifono - strukturo.

Prav takšna raba sicer pa je verjetno tudi najbolj tipična. Iz obravnavanih primerov je namreč več kot očitno, da je vloga sicer pa in ker pa prav uprizoriti, zaigrati polifono strukturo besedila, naloga, ki ne bi bila izved- 
ljiva brez pa v vlogi modifikatorja sicer. Še več: polifonost - četudi le dvostopenjska (kot v drugem besedilu) - je, kakor smo videli, vpisana že v sam veznik sicer pa. Preverimo to hipotezo in si za konec oglejmo še zadnje besedilo.

\section{Polomljene opozorilne table v Tivoliju ${ }^{17}$}

[komentar fotografije]

Reden obiskovalec Tivolija nas je opozoril, da so nekatere table, ki opozarjajo lastnike psov, da morajo pripeti svoje štirinožne prijatelje z vrvico, že polomljene. Kdo lomi table, niso vedeli povedati tudi v podjetju Rast, ki vzdržuje Tivoli. Povedali pa so nam, da imajo vsako leto veliko škode zaradi polomljenih tabel in klopi ter razbitih luči, saj izživljanje nekaterih nad mestno lastnino ne pozna meja.

Besedilo je interpretativno povsem avtonomno in neodvisno in ne potrebuje nobenih dodatnih pojasnil. In vendar se zaključi s temle stavkom:

(79) Sicer pa vsako večjo škodo prijavijo miličnikom.

$S$ takšnim dodatkom do tedaj povsem koherentno besedilo nenadoma izgubi svojo transparentnost. Da je vzrok te netransparentnosti prav sestavljeni veznik sicer pa, nam lahko pokaže zelo preprosta analiza: zadnji del besedila govori o tem, da neznanci v parku ne lomijo le raznih napisnih tabel, temveč tudi klopi in luči, ter da »izživljanje nekaterih nad mestno lastnino ne pozna meja«. Povsem upravičeno in nedvoumno (še zlasti, ker gre le za krajši komentar pod sliko) bi novinar sestavek lahko sklenil le $\mathrm{z} V$ sako večjo škodo prijavijo miličnikom, torej tako, da ne bi uporabil veznika sicer pa; besedilo bi v tem primeru še vedno ohranilo svojo avtonomijo in transparentnost. Toda že dejstvo, da se sicer pa pojavi, razgiba linearno strukturo besedila in mu odvzame njegovo neposredno transparentnost $s$ tem, ko se sklicuje na neko (v zvezi z besedilom) izven-diskurzivno podporo. Zato moramo vpeljati dva dodatna izjavljalca (povezana s sicer pa).

Najsplošnejšo polifono strukturo sestavljenega veznika ...pa - kjer pa ne služi le za krepitev predhodnega veznika, ampak nastopa tudi kot modifikator njegove argumentativne usmerjenosti - bi lahko opredelili takole:

- I1 (ki ni nujno prvi izjavljalec v besedilu) poroča o nekih dejstvih (v danem primeru polomljenih tabel v Tivoliju neodgovornost ali razsipavanje z družbeno lastnino itd.); 
- I2 odgovarja I1 (mu nasprotuje, ga pomirja itd.) z navajanjem neke skupne, splošne ali implicitne vednosti iz ozadja, nekega predhodnega diskurzivnega segmenta ali izven-diskurzivnega dejstva (v primeru polomljenih tabel v Tivoliju: vsako škodo prijavijo miličnikom).

\section{Sklepna opažanja}

Slovar slovenskega knjižnega jezika navaja 29 različnih načinov rab veznika $p a$, ki verjetno velja za enega (kontekstualno) najbolj raznolikih in najširše rabljenih leksemov $\mathrm{v}$ slovenščini. $V$ angleščino bi pravzaprav skoraj vse njegove rabe lahko prevedli kot and (in včasih but) ali, natančneje, nadomestili z in, ki je slovenska (nezaznamovana) dvojnica angleškega and. Toda če to klasifikacijo primerjamo s korpusom slovenskega (govorjenega in pisanega) jezika Nova beseda, kaj kmalu ugotovimo, da obstaja še neka druga raba pa, kjer pa nastopa v vlogi modifikatorja (drugih) veznikov.

Moja (hipo)teza je bila, da v določenih sestavljenih veznikih (večinoma sem se omejil na kerpa in sicer pa),pa lahko nastopa bodisi kot modifikator - sprevračevalec - argumentativnega pričakovanja in usmerjenosti (kot v primerih (29)-(31)) bodisi kot modifikator - okrepitelj - pomena in moči predhodnega veznika (kot v primerih (32)-(36)) in ne zgolj kot propozicijski (ali gramatični) operator (kot v primerih (1)-(28)).

$\mathrm{Na}$ osnovi substitutivne analize in analize primerov iz tiska lahko sklepamo, da ima $p a \mathrm{v}$ sestavljenih veznikih ker $p a$ in sicer pa vlogo neke vrste anaforičnega elementa, ki s tem, ko omogoča referenco na neke vrste skupno, splošno ali implicitno vednost iz ozadja, nek predhodni diskurzivni segment ali izven-diskurzivno situacijo, razkriva polifono strukturo danega diskurzivnega segmenta in mu tako daje interpretativno neodvisnost in avtonomijo. Med tem ko se ker pa večidel nanaša na (možne) razloge, je sicer pa večinoma omejen na (možna) pojasnila o tem, o čemer se poroča $\mathrm{v}$ potekajočem diskurzu. Če sta rabljena brez $p a, k e r$ in sicer ne omogočata tovrstnih referenc.

Na koncu prispevka predlagam tudi temeljno strukturo sestavljenega veznika ... pa v polifonem smislu, ki sestoji (vsaj) iz dveh izjavljalcev:

- I1 (ni nujno prvi izjavljalec v besedilu) poroča o nekih dejstvih;

- I2 odgovarja I1 (mu nasprotuje, ga pomirja itd.) z navajanjem neke skupne, splošne ali implicitne vednosti iz ozadja, nekega predhodnega diskurzivnega segmenta ali izven-diskurzivnega dejstva. 
MOJCA

SCHLAMBERGER

BREZAR

SLOVENSKI

ZAZNAMOVALCI

V LUČI TEORIJE

ARGUMENTACIJE V

JEZIKU 



\section{Slovenski členki}

med argumentacij-

skimi operatorji in

konektorji

\section{Opredelitev členka kot besedne vrste}

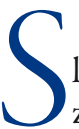

lovenski členki imajo poseben status napol priznane besedne vrste: zakaj napol? V SSKJ se beseda členek rabi samo za opredelitev besedotvornih členkov, ostali t. i. »členki« spadajo med prislove oziroma veznike oziroma oboje hkrati. Podobno kot prislovi je ta besedna vrsta sprejemala vse besede, ki se jih ni dalo uvrstiti drugam. V nekaterih jezikih, npr. francoščini, angleščini, nimajo statusa posebne besedne vrste. V drugih, npr. nemščini, češčini, makedonščini, bolgarščini, ga imajo. Po funkcijski slovnici bi sodili med operatorje, ki se kodirajo in delujejo na različnih ravninah. ${ }^{1}$ Zanimivi so postali predvsem za pragmatično orientirane raziskave in raziskave govorjenega jezika. ${ }^{2}$ Dejansko gre za besede, ki se jih po pomenu najde $\mathrm{v}$ praktično vseh jezikih in vstopajo $\mathrm{v}$ podobne opozicije kot $\check{s} e$ in $\check{z} e$ pri nas (prim. already, not yet $\mathrm{v}$ angleščini, déjà, presque, pas encore $\mathrm{v}$ francoščini). Drugod jih postavijo med prislove - tudi sicer je besedna vrsta prislov oznaka za zelo heterogeno kategorijo, v katero spada vse, česar niso mogli umestiti drugam. Podobno lahko trdimo tudi za členke.

\footnotetext{
${ }^{1}$ Prim. S. C. Dik, The Theory of Functional Grammar. Part I: The structure of the clause, Dordrecht 1989.

${ }^{2}$ Primerjava funkcije modalnih členkov in členkov v vezniški obliki v M. Schlamberger Brezar, Vpliv pragmatičnega jezikoslovja na raziskave slovenskega jezika: primer členkov, v: Z. Jan (ur.), Slovensko jezikoslovje danes in jutri, Zbornik Slavističnega društva Slovenije 10, Ljubljana 1999; M. Schlamberger Brezar, Les connecteurs en combinaison avec les marquers modaux: l'exemple du français et du slovène, Linguistica XL (2000),2, 273-282; I. Ferbežar et al., Sporazumevalni prag za slovenščino 2004, Ljubljana 2004.
} 
Vendar jih združuje odnosna funkcijska vloga - za vse členke, razen besedotvornih, lahko trdimo, da modificirajo odnos do propozicionalne vsebine oziroma do izrečenega in da o njihovem pomenu lahko govorimo predvsem v odvisnosti od konteksta.

Členki so bili v slovenščini kot besedna vrsta definirani leta $1974 \mathrm{~s}$ člankom J. Toporišiča Kratko oblikoslovje slovenskega jezika. ${ }^{3}$ Mednje je uvrstil primere, ki jih prej v zbirki Slovenski knjižni jezik ${ }^{4}$ obravnaval kot prislove, po katerih se ni mogoče vprašati. ${ }^{5}$

Po klasifikaciji v Slovenski slovnici $1976^{6}$ jih je razdelil na 13 razredov, med katerimi loči navezovalne členke ( $a$, in, ja, no, pa, potem, torej, tudi), členke čustvovanja (žal, dobro), poudarne (ravno, posebno, zlasti, predvsem), izvzemalne (le, samo, edino, komaj, vsaj), presojevalne (tako, blizu, približno, skoraj, domala), dodajalne (tudi, prav tako, niti, takisto, vključno), členke zadržka (pravzaprav, pač, saj, komaj, že, sicer), potrjevanja ali soglašanja (da, dejansko, gotovo, ja, kajpak, res, seveda), možnosti, verjetnosti (morda, mogoče, morebiti, nemara, končno, navsezadnje, brž, verjetno, komaj), mnenja, domneve (baje, menda, denimo), vprašalne členke (ali, a, kaj, mar), spodbujalne (trdilni: a, ali, da, kako, morda; nikalni: da, kaj, še, ko, nikdar, saj) ter členke zanikanja in soglašanja (ne, nikar, vraga, figo).

V Slovenski slovnici iz leta 2000 se prvotni klasifikaciji odreče in predlaga še novo, po kateri se členki delijo na pozivne, vrednotenjske, čustvenostne in besedilnozgradbenostne, vsaka skupina pa še na več podskupin. ${ }^{7}$ Po njegovi novejši definiciji, ki je formalno-pomenska, so členki »nepregibna besedna vrsta: z njimi vzpostavljamo zveze s sobesedilom, izražamo pomenske odtenke posameznih besed, delov stavka, celih stavkov in povedi ali pa tvorimo skladenjske naklone. $\ll^{8}$ Toporišič opredeli tudi odnos do drugih besednih vrst: »Nekateri členki se po vlogi približujejo veznikom, drugi prislovom. ${ }^{9} \mathrm{~V}$ resnici pa ni natančnega ločevanja med tema dvema besednima vrstama. Da je negotovost med odnosnimi besedami še večja, se členki sinonimno pojavljajo tudi kot vezniki oziroma prislovi. O kontekstualno določenem pomenu, ki ga hoče Toporišič na vsak način oprede-

\footnotetext{
${ }^{3}$ J. Toporišič Kratko oblikoslovje slovenskega knjižnega jezika, v: M. Kmecl, T. Logar, J. Toporišič (ur.), Slovenski jezik, literatura in kultura: informativni zbornik, Ljubljana 1974.

${ }^{4}$ J. Toporišič, Slovenski jezik 1-4, Maribor 1966.

${ }^{5}$ I. Černelič, Členek kot besedna vrsta v slovenskem knjižnem jeziku, Jezikoslovni zapiski 1, Ljubljana 1991,73-85.

${ }^{6}$ Jože Toporišič, Slovenska slovnica, Maribor 1984, 384-385.

${ }^{7}$ J. Toporišič, Slovenska slovnica, Maribor 2000, 445-448.

${ }^{8} \mathrm{~J}$. Toporišič, n. d., 445.

${ }^{9}$ N.m.
} 
liti, se lahko prepričamo med podvrstami pozivnih členkov, kjer saj nastopa tako kot nasprotovalni kot tudi grozilni členek. ${ }^{10}$

I. Černelič-Kozlevčar ${ }^{11}$ poda poglobljenejšo slovnično delitev glede na upoštevanje formalnih meril, kot so »nanašanje na cel stavek ali le člen stavka, pastavčnost, vezanost na določen skladenjski naklon, vrsto stavčnega člena in besedno vrsto, ki ga izraža, in na njeno pomensko skupino ter upoštevanje jezikovne ravnine, ki omogoča razmejitev členkov, ki so le besedotvorne prvine ali pa sredstvo za opisne oblike $(-k o l i, s i$, se) in členkov, ki so samostojne besede $\ll .{ }^{12}$ Predlaga naslednje združevanje Toporišičevih vrst členkov:

1. Skladenjskonaklonski členki vključujejo vzpodbujevalne in vprašalne členke, za katere je značilno, da opravljajo določeno vlogo v stavku glede na skladenjski naklon;

2. naklonski členki so členki, ki izražajo možnost, verjetnost, mnenje, domnevo in zadržek, torej razmerje do stvarnosti, resničnosti povedanega;

3. poudarni členki združujejo poudarne, presojevalne in izvzemalne členke; skupno jim je, da se nanašajo na posamezen stavčni člen in ga $\mathrm{v}$ stavku podčrtujejo, izpostavljajo;

4. nikalni členki združujejo členke zanikanja in nesoglasja;

5. čustveni članki so osamosvojeni.

Delitev členkov na pet skupin je sprejemljivejša, saj združuje opis členkov s funkcijskega in pragmatičnega stališča ter ločuje komentar izrekanja in členke, ki delujejo na ravnini propozicij. Ob predpostavki, da členek predstavlja posebno besedno vrsto (ki mu je SSKJ ne priznava - z izjemo besedotvornih členkov) in da so vsi glede izražanja odnosa do povedanega modalni, bi se njegove opredelitve lotili na podlagi delitve, predstavljene leta $2000,{ }^{13}$ ki smo jo nadgradili v Sporazumevalnem pragu ${ }^{14}$ in po kateri členke funkcijsko-pomensko razdelimo med naslednje štiri vrste modalnih členkov:

1. inherentno modalne členke, kjer je modalnost dana v pomenu (lahko, mogoče, morda, gotovo, verjetno);

\footnotetext{
${ }^{10} \mathrm{~J}$. Toporišič, n. d., 448.

${ }^{11}$ I. Černelič-Kozlevčar O delitvi členkov. Vprašanja slovarja in zdomske književnosti, Zbornik Slavističnega društva Slovenije 3, Ljubljana 1993, 213-227.

${ }^{12}$ I. Černelič-Kozlevčar, n. d., 225.

${ }_{13}$ M. Schlamberger Brezar, Les connecteurs en combinaison avec les marquers modaux: l'exemple du français et du slovène, Linguistica XL (2000), 2, 105.

${ }^{14}$ I. Ferbežar et al., Sporazumevalni prag za slovenščino 2004, Ljubljana 2004.
} 
2. epistemično modalne členke, ki izražajo odnos do propozicionalne vsebine, torej govorčev odnos do povedanega ( $\check{s e}$, že, tudi, komaj);

3. skladenjskonaklonske členke, ki delujejo na ravni izreka in spreminjajo skladenjski naklon izreka (naj, a, vsaj);

4. členke kot zaznamovalce zgradbe diskurza, ki se najpogosteje pojavljajo $\mathrm{v}$ govorjenem diskurzu in zagotavljajo navezovanje na prej povedano. Pojavljajo se v začetku izrekov, pred temo in remo, a niso del teme in reme $(\check{z} e, s a j, n o, . .$.$) .$

Iz te delitve so izvzeti besedotvorni členki.

V Sporazumevalnem pragu $2004^{15}$ smo se odločili za naslednjo delitev členkov, ki prejšnje kategorije nekoliko preimenuje, ne da bi jih vsebinsko predelala, in dodaja besedotvorne členke:

1. modalni členki za izražanje nujnosti, verjetnosti, možnosti;

2. poudarni členki, ki izražajo govorčev odnos do povedanega in nakazujejo informacijo, ki ni izrečena;

3. zaznamovalci tipa povedi;

4. odnosni členki, ki služijo kot povezovalci v diskurzu;

5. besedotvorni členki.

Tudi delitev po Sporazumevalnem pragu ${ }^{16}$ členke opredeli kot posebno besedno vrsto. Ćlenki »določajo odnos do konteksta ali delno spreminjajo pomen povedi. So blizu veznikom, s katerimi jih povezuje njihova odnosna vloga, ali prislovom, s katerimi jih druži vloga modalizatorjev povedi. $\ll{ }^{17}$

Za dokazovanje argumentacijske vrednosti, ki jo dodajajo izreku, so za nas pomembni členki skupine 2, torej prej epistemično modalni in zdaj poudarni členki, ki izražajo govorčev odnos do povedanega in delujejo kot operatorji, in členki skupine 4, torej zaznamovalci zgradbe diskurza ${ }^{18}$ oziroma odnosni členki, ki služijo kot povezovalci v diskurzu ter imajo vlogo konektorjev. Ta dva podrazreda lahko opredelimo kot funkcijsko kategorijo z argumentacijsko vrednostjo. Argumentacija izvira predvsem iz odnosne vloge členka, $s$ katerega rabo govorec opredeli povedano v odnosu do drugih izrečenih oziroma zamolčanih vsebin. Vezniška vloga členkov je v Toporišičevi Slovnici ${ }^{19}$ obravnavana kot sinonimija členka, za nas pa pomeni zgolj eno od funkcij.

\footnotetext{
${ }^{15}$ I. Ferbežar et al., n. d., 239-240.

${ }^{16}$ N. d., 239.

${ }^{17}$ N.m.

${ }^{18}$ Zaznamovalci zgradbe diskurza je prevedek za discourse markers $\mathrm{v}$ an. in francoske marqueurs discursifs.

${ }^{19} \mathrm{~J}$. Toporišič, Slovenska slovnica, Maribor 1976, 2000.
} 


\section{Členki z argumentacijsko vrednostjo $v$ govorjenih besedilih}

Analiza členkov v govorjenih besedilih je potekala na neoznačenem korpusu govorjenih besedil, ki je bil posnet leta 1992 za potrebe raziskovanja pogajalskega sporazumevanja ${ }^{20}$ in v korpusu Fidaplus (www.fidaplus. net) s poudarkom na govorjenih besedilih. Govorjena besedila, ki se jih da izolirati pri ukazu »razširjeno iskanje«, so bodisi dramska besedila, bodisi transkripti parlamentarnih debat od leta 1994 do 1999.

Členki v korpusu Fidaplus tudi sicer predstavljajo problem ker, kot navajata avtorja,

»ezikovni priročniki prinašajo nasprotujoče si informacije o besednovrstni pripadnosti velikega deleža besed, ki naj bi spadale (tudi) v besedno vrsto členkov: npr. besede predvsem, približno, resda, končno, prav, ... - ponekod so uvrščene med členke, ponekod med prislove, ponekod kot dvojnice v obe kategoriji. Med enakopisnimi prislovi ter členki naj bi se ločevalo izključno z upoštevanjem semantike konteksta, tj. z uporabo vprašalnice, ki jo v primeru prislovov lahko zastavljamo, v primeru členkov pa ne. Do zadreg, ali je neka beseda v določenem kontekstu členek ali ne, prihaja že na ravni ročnega določevanja, za avtomatsko analizo je naloga torej povsem neizvedljiva. $\ll^{21}$

Problem nastaja predvsem pri ločevanju členkov od prislovov: edino ločevalno sredstvo med obema naj bi bilo, ${ }^{22}$ da se po členkih ne da vprašati. Poleg tega smo izpostavili tudi njihovo vezniško vlogo. Iz vsega navedenega sledi, da po teoriji argumentacije v jeziku ${ }^{23}$ lahko slovenske členke funkcijsko opredelimo kot operatorje ali konektorje oziroma povezovalce. Argumentacijsko vrednost imajo predvsem členki iz skupine t. i. epistemičnih ${ }^{24}$ oziroma poudarnih členkov po definiciji v Sporazumevalnem pragu. ${ }^{25}$

Po teoriji argumentacije $\mathrm{v}$ jeziku ${ }^{26}$ je ta namerno dejanje, ki je hkrati institucionalno in konvencionalno. Konvencionalnost argumentacije se kaže v tem, da zanjo uporabljamo dogovorjena sredstva, ki so operatorji in konektorji. Ducrot in Anscombre operatorje in konektorje opredelita kot nosilce argumentacije. Med seboj se razlikujejo po tem, ali so eno- ali dvosmerni.

\footnotetext{
${ }^{20}$ M. Schalmberger Brezar, Zgradba pogajalske komunikacije, magistrska naloga, Ljubljana 1996.

${ }^{21}$ Krek, Arhar, 2007: http: //nl.ijs.si/jos/msd/html-sl/josMSD-sl-back.1_div.2_div.9.html.

${ }^{22}$ J. Toporišič, Slovenski jezik 1-4, Maribor 1966.

${ }^{23}$ J.-C. Anscombre, O. Ducrot, L'Argumentation dans la langue, Bruselj 1983.

${ }^{24}$ M. Schlamberger Brezar, Vloga povezovalcev v diskurzu, v: I. Štrukelj (ur.), Jezik za danes in jutri, Zbornik referatov na II. kongresu Društva za uporabno jezikoslovje, Ljubljana 1998.

${ }^{25}$ I. Ferbežar et al., n. d.

${ }^{26}$ J.-C. Anscombre, O. Ducrot, n. d.
} 
Operatorji so enosmerni in spreminjajo argumentacijsko orientacijo povedi, na katero delujejo. Naj ponovno navedemo enega njunih najznačilnejših primerov: ${ }^{27}$

(1)

Il est huit heures, il faut se dépecher.

Il est huit heures, il nous reste du temps.

(2)

Il n'est que huit heures. Il nous reste du temps.

*Il n'est que huit heures. Il faut se dépecher.

(3)

Il est presque huit heures. Il faut se dépecher.

*Il est presque huit heures. Il nous reste du temps.

Kot vidimo, je argumentacija v primeru (1), il est huit heures, možna v smereh - il faut se dépecher (treba je hiteti) in il nous reste du temps (se je čas). Ko dodamo argumentacijska operatorja presque in ne ...que, sta ta usmerjena proti nasprotnima zaključkoma. Argumentacija ni več možna v okviru obeh zaključkov, ki sta podana v primeru brez tega operatorja, ampak samo še v eni smeri. Operatorja sta torej izreku dodala argumentacijsko usmeritev

Pri zgornjih kanoničnih Ducrotovih primerih imamo dve možnosti prevoda $\mathrm{v}$ slovenščino, ki omogočata različne interpretacije:

(4)

Ni še osem, še imamo čas.

*Ni še osem, treba je pohiteti.

(5)

Osem je že, treba je pohiteti.

*Osem je že, še imamo čas.

$\left(5^{\circ}\right)$

Skoraj osem je, treba je pohiteti.

*Skoraj osem je, še imamo čas.

Francoska ne ... que in presque smo nadomestili s členki še in $\check{z} e$ oziroma skoraj. Vidimo, da sta členka še in že v nasprotju tako po samem pomenu kot po argumentacijski vrednosti. Podobno argumentacijsko vrednost kot $\check{z} e$, vendar z omejitvijo, da prag še ni dosežen, ima skoraj. V nadaljevan-

${ }^{27} \mathrm{~J}$. Moeschler, Argumentation et conversation. Éléments pour une analyse pragmatique du discours, Paris 1985, 58. 
ju si bomo ogledali njihovo vlogo ter vlogo členkov, ki delujejo na podoben način.

\section{Členki v vlogi operatorjev}

Uporaba členka v diskurzu pomeni dejanje argumentacijske usmeritve. Govorec usmeri izraz tako, kot mu najbolj ustreza za argumentacijo. S tem argumentira predvsem implicitno. V izreku Prišel je tudi Jaka zaradi členka tudi vemo, da Jaka ni bil sam; če pa rečemo Prišel je vsaj Jaka, je s tem izpolnjen že nek minimalni pogoj, da smo zadovoljni, medtem ko z izrekom Prišel je celo Jaka nakažemo, da je bilo dejstvo, da je prišel, res izjemno.

V govorjenem diskurzu posnetih pogajanj in korpusa Fidaplus smo izpostavili naslednje členke, ki delujejo kot operatorji: $̌$ š in že, po Ducrotovi teoriji operatorja, ki omejujeta možnosti argumentacijskih sklepov, sta si na videz diametralno nasprotna. Sledita jima skoraj, ki z njima vstopa v kombinacije, in kar, pa nasprotujoča si vsaj in tudi, poudarna členka pač in sploh, na koncu pa še sinonimna členka le in samo, ki delujeta kot operatorja izvzemalno, hkrati pa se kot konektorja vključujeta v argumentacijska gibanja. Vsak členek v začetku razčlenimo z opisi, ki so podani v SSKJ, potem pa se osredinimo na najznačilnejše rabe v korpusu Fidaplus, po možnosti argumentacijske.

\section{ŠE IN ŽE, NASPROTJE V ARGUMENTACIJSKI ORIENTACIJI}

Po Slovarju slovenskega knjižnega jezika (SSKJ) ima še, ki je tam opredeljen kot prislov, naslednje vrednosti:

1. izraža nadaljevanje trajanja - On še dela.

2. z zanikanim povedkov izraža, da se pričakovano dejanje ali stanje do trenutka govorjenja ne uresniči - Tega še nisem vedel.

3. izraža ponovitev dejanja ali stanja - Povabila jih je, naj še pridejo.

4. izraža dopustitev dejanja ali stanja - ̌́e padla bo če ne bo pazila.

5. izraža dodajanje - Tam so ostali še dva meseca.

6. izraža, da kaj ni omejeno na navedeno - Še odrasli se ga bojijo.

7. izraža presenetljivost česa - Zjutraj je šla še v službo, zvečer je bila že mrtva.

8. poudarja navedeni čas z izključevanjem poznejšega - Še včeraj je bilo to mogoče.

9. v nikalnem stavku - izraža nedoseženost količine - Še petnajst let ni stara. 
10. poudarja pomen besede, na katero se nanaša - Obleka je še kar dobra.

11. navadno s primernikom krepi pomen primernika - Pot je bila še daljša, kot smo predvidevali.

// s presežnikom omejuje presežnik - Predstava ni navdušila, še najboljša je bila glasba.

12. ekspresivno, navadno v zvezi s kaj (še kaj) - izraža močno zanikanje - Kajpa še!

$\check{S} e$ v avtentičnih besedilih deluje kot operator, ki modificira glagol, prislov, samostalnik, zaimek in tudi veznik. V korpusu ima 100.000 pojavitev, od tega 11.281 v govornem prenosniku. Pojavlja se tudi v zloženih veznikih - konektorjih, tudi tu z dodajalno vsebino, v oblikah še posebej, $\check{s} e$ zlasti, še nekaj. Nekaj primerov tipične rabe dodajamo v nadaljevanju:

(6)

Dr. Wilbur pravi, da bo po ovcah poskusil s kravami. Verjetno pa je samo še vprašanje časa, kdaj se bo kdo lotil podvojitve človeka. (www.fidaplus.net; Dnevnik)

(7)

Toda če je Pipo, še preden je postal Nazionale in Super, v prvih letih svojega festivala kazal spontan talent za obvladovanje prostora in kamer ter zmerno mero očetovstva (najbolj znan je primer, ko je še ne dvajsetletnemu zmagovalcu San Rema 1990, Erosu Ramazzottiju, med razglasitvijo rezultatov ukazal, naj da roke iz žepov), so njegove zadnje prireditve v San Remu presegle meje decentne režije. (www.fidaplus.net; Dnevnik 1997)

V zgornjih primerih je še del besedne zveze samo še, šepreden, $\check{s} e n e d v a j-$ setletnemu. Primeri iz govornega prenosnika se uporabljajo podobno: $\mathrm{v}$ primeru (8) gre za stopnjevanje, v primeru (9) za dodajanje:

\section{(8)}

Gospod Kopač je danes rekel, da si je vzel tri tedne časa in iz teh treh tednov ni rodil niti enega samega piškavega amandmaja, ki bi bil še kako potreben po njegovem mnenju in ki bi kakovost zakona oziroma spremembe zakona, ki ga danes sprejemamo, lahko izboljšal do te mere, da bi bil zadovoljen tudi on kot predsednik odbora in kot poznavalec te problematike. (www.fidaplus. net; DZ 1995)

(9)

In še nekaj. Tega ne bomo mi sanirali - poslanke in poslanci tukaj. To bodo sanirali tisti, ki delajo v Sloveniji včasih tudi za 40.000 naših tolarjev. To bodo 
sanirali tisti, ki še konec februarja, kot recimo v TAM-u, ne dobijo plače za januar. To sanirajo tisti ljudje - ostale primere, ki bi se jih dalo tukaj še naštevati, si bom prihranil za kdaj drugič. (www.fidaplus.net; DZ 1996)

Še v povezavi s samostalniki se uporablja bodisi za izražanje količine, bodisi trajanja določenega stanja: ̌̌e dve leti, je še študent. Kot argumentacijski operator, ki izraža predvsem poudarjanje v določeni smeri, še torej nima posebnih vrednosti glede na tiste, opisane v SSKJ. Lahko bi rekli, da je vrednosti v korpusu manj, kot jih je opisanih, to pa predvsem zaradi narave prenosnika. Še v neoznačenem korpusu pogajalskega sporazumevanja je pogosteje posejan, seveda $\mathrm{v}$ kombinaciji z drugimi argumentacijskimi operatorji že, kar, seveda (primer (10):

(10)

No, pravzaprav sva se nekaj že po telefonu dogovorila. Me te vaše smuči pri-

bližno poznamo, smo se kar nekaj pozanimali o njih, in gre za večjo količi-

no, kot sem vam že omenila, seveda, o cenah nisva še nič govorila, verjetno se

bova pa danes lahko o vsem tem tudi pomenila. ${ }^{28}$

Členek, operator, konektor že se v vseh prenosnikih ustavi na 100.000 pojavitvah, v govornem prenosniku pa najdemo 6803 pojavitev. Njegove vloge v SSKJ so naslednje:

1. izraža, da stanje, dejanje nastopi prej, kot je bilo pričakovano - $\mathrm{Ni}$ sem vedel, da je že tako pozno.

//izraža, da je čas, v katerem dejanje nastopi, zgodnejši, kot se pričakuje $-\check{Z}$ ejutri bo prost.

2. izraža nastop, obstajanje dejanja a) pred časom govorjenja ali v njem - To semže slišal;

b) do navedenega časa ali v njem - Ob osmih bo že odpotoval.

3. izraža, da je količina, mera dosežena do časa govorjenja ali določenega časa večja od pričakovane - Že dve uri čakajo.

4. navadno na začetku stavka - izraža zadostnost navedenega ne glede na drugo mogoče - Že ime pove vse.

5. poudarja odvisnost možnosti dejanja od kake okoliščine - To ste že naredili, ker so vam pomagali.

6. izraža gotovost, prepričanost glede česa brez nestrpnosti glede časa uresničitve - Bomo že našli kakizhod.

${ }^{28}$ M. Schlamberger Brezar, Zgradba pogajalske komunikacije, magistrska naloga, Ljubljana 1996 (primer: Določanje cen o smučarski opremi). 
//izraža prepričanost o čem sploh - Vi boste že šli, drugi pa najbrž ne.

7. izraža sprijaznjenje s čim - Ne čudite se preveč, je že tako.

8. navadno z velelnikom izraža nejevoljo, nestrpnost v pozivu - Daj mi že mir!

// v želelnem stavku poudarja željo po uresničitvi - Ko bi bili izpiti že mimo!

9. izraža, da dejanje v nadrednem stavku nastopi neposredno za dejanjem v odvisnem stavku - Komaj je odšla, že so se začeli smejati.

//izraža, da je dejanje neposredno pred uresničitvijo - Že je hotel oditi, ko so ga poklicali.

10. za izražanje pridržka, ki ga utemeljuje drugi stavek - Piše že, vendar slabo.

11. ekspresivno, v nikalnih stavkih poudarja zanikanje - Jaz že ne!

12. ekspr., v zvezi s prislovi za izražanje velike časovne ali krajevne oddaljenosti - Kje je že to!

13. v zvezi s tako, tako in tako za poudarjanje dejstva, ki brez nadaljnjih podatkov utemeljuje sklep -Že tako in tako majhno plačo so mu še zmanjsali.

14. z zaimki in prislovi za izražanje in poudarjanje poljubnosti - Naj bo kakšna že, rad jo ima.

15. ekspr., z vprašalnimi zaimki ali prislovi poudarja ugibanje, ponovno vprašanje - Kdo ga že išče?

16. v vezniški rabi, v pogojnih odvisnih stavkih, navadno v zvezi če že za izražanje pridržka - Naj gredo, če že hočejo.

// z nikalnico za izražanje izvzemanja - Jabolka so vsaj lepa, če že ne okusna.

// ekspr., v stopnjevalnem priredju za izražanje omejenosti na prvi člen - Že hodi težko, kaj šele teče.

17. v medmetni rabi: izraža zadržano pritrjevanje - Že, toda... že, a kdo bo vse to plačal...

//izraža sprijaznjenje s čim - Bo že kako.

Žev avtentičnih besedilih ima bodisi vlogo operatorja, bodisi konektorja (povezovalca). V zadnji vlogi nastopa v dopustnih izrekih in dopustnih argumentacijskih gibanjih (kar bo podrobno predstavljeno kasneje): ${ }^{29}$ do

${ }^{29}$ Glej poglavje Toposi, konektorji in argumentacijska gibanja. 
izraza pride v prvem stavku za izražanje dopuščanja, sledi stavek, ki ga uvaja protivni veznik (rabe 9, 10, 14, 16 in 17 v SSKJ, opisane zgoraj).

$\check{Z} e \mathrm{v}$ govornem prenosniku pojasnjuje, da je dejanje že bilo storjeno (primera (11) in (12) spodaj):

Če hočete karkoli dodati k temu - replike ni. Prosim? (Poslanec govori iz klopi.) Ja, to je pa prepozno. Replika je bila že. Proceduralno? (www.fidaplus. net;DZ 1998)

Še enkrat poudarim, lahko vam zgolj verjamemo, kaj več kot to se ne da, zelo težko, ker kljub vsemu še ni tistega osnovnega podatka, iz katerega bi lahko razbrali, kaj od tega je bilo že odplačano. (www.fidaplus.net; DZ 1998)

V primeru (13) že izraža količino v povezavi s količinskimi izrazi 3,5 milijarde, 2/3 tistega, kar ... :

Tako, da na koncu je to približno milijardo 600 ameriških dolarjev. Če prištejemo še tisto, kar že imamo, potem smo pa že preko 3,5 milijarde, blizu 4, to pa ni več tako majhna obremenitev za dvomilijonski narod. To je treba gledati. Treba je tudi nekoliko širše pogledati, da ima Vlada v proceduri še kar nekaj zakonov, s katerimi želi najemati nove kredite. Vsi ti krediti bodo prihajali približno v istem času, razlika je mogoče 5 let, v odplačilo. Torej bo slovenska ekonomija, ali pa gospodarstvo, kakor želite, imela to breme, ki je že skorajda 2/3 tistega, kar ima zdaj sosednja Madžarska, ki velja za izredno zadolženo državo. Zato te številke niso tako nedolžne, čeprav, tako na prvi pogled, sploh niso velike. (www.fidaplus.net; DZ 1996)

Spodnje vloge v primerih 14 do 17 zaznamujejo poudarjanje povedanega; so najbolj tipične govorne oblike, kjer že nastopa v odnosu do dela izreka, ki je presenetljiv. To je tipična členkovna raba.

(14)

Toda bistveno vprašanje je vsebinsko, kaj ta dva dokumenta v resnici predstavljata. Običajno imamo tak postopek pri mednarodnih pogodbah, ko je mednarodna pogodba sestavni del zakona o ratifikaciji te pogodbe in je vključena običajno že kar v 2. ali pa 3. člen s celotnim besedilom, s podpisi vred. (www.fidaplus.net; DZ 1996)

(15)

-Ti že nismo. -Policija! (www.fidaplus.net; Ameriška pita) 
(16)

JE ŽEV REDU. LAHKO. (www.fidaplus.net; Ameriška pita 2)

(17)

POČASI. JAZ JIH ŽE NISEM VZEL. (www.fidaplus.net; Kremenčkovi, Viva Rock Vegas)

Poleg vrednosti, nasprotnih še, ima že tudi vlogo konektorja. Pojavlja se še v diskurzivnih gibanjih, predvsem v protivnih. Kot tak bo podrobno prikazan $\mathrm{v}$ nadaljevanju o toposih in argumentacijskih konektorjih, predvsem v povezavah že res, že že ampak; že mogoče, vendar, kjer navezave z že tvorijo prvi del protivno-dopustnega argumentacijskega gibanja. ${ }^{30}$ Tak je drugi že v primeru (18), tokrat v kombinaciji če že:

(18)

Zato poudarjamo, da če hočemo ohraniti tudi motivacijo bank pri reševanju tega problema, jih ne moremo tako rekoč na realsocialističen način že honorirati in nato pričakovati, da bodo zaradi svoje silno visoke razredne zavesti pravilno delovale in učinkovito vodile podjetja. Rezultati realsocialističnega gospodarstva in današnji polom vseh teh velikanov kažejo, da je to bila skrajno naivna, če že ne bedasta koncepcija. (www.fidaplus.net; DZ 1995)

Po pregledu posameznih oblik še in $\check{z} e$ poglejmo, kako sta si argumentacijsko nasprotno usmerjena. Pri zanikanju se oba veznika prepletata med seboj, dopolnjuje ju členek več. Vzemimo dva izreka v skladu z evropskim delovnim časom, npr. (19) in (20) spodaj:

Ura je devet, Jaka že dela.

(20)

Ura je pet, Jaka śe dela.

Kako postaviti vprašanje glede na zgornja izreka in kakšen odgovor lahko dobimo? Vprašanje, ki ga lahko postavimo na podlagi primera (19), je spodaj v (19'), sledi mu vprašanje na podlagi primera (20). Vsakokrat sta možna dva odgovora a) in b).

$\left(19^{\circ}\right)$

A Jaka že dela?

a) Da, že dela.

b) $\mathrm{Ne}$, ne sé

${ }^{30}$ Glej poglavje Toposi, konektorji in argumentacijska gibanja. 
$\left(20^{\circ}\right)$

A Jaka še dela?

a) Da, se dela.

b) $\mathrm{Ne}$, ne dela već.

Vidimo, da se pri zanikanju izrekov argumentacijska vrednost členkov obrne, $\breve{s} e$ in $\check{z} e$ sta si po argumentacijski orientaciji nasprotna.

\section{SKORAJ, KAR}

Skoraj in kar označujeta mero, stopnjo; skoraj predvsem označuje stanje blizu končne stopnje ali mere, kar pa visoko vrednost mere ali stopnje, predvsem $v$ očeh govorca, kar mu daje argumentacijsko vlogo.

Skoraj ima v SSKJ naslednje vrednosti:

1. izraža precejšnje približevanje polni meri - Skupaj sta delala skoraj deset let.

2. izraža precejšnje približevanje polni stopnji povedanega - Njegova koža je skoraj črna.

3. nav. ekspr., pri naštevanju: dopolnjevanje, rahlo stopnjevanje povedanega - Spridušenim glasom, skoraj šepetaje, je začel peti.

4. izraža, da je bilo dejanje blizu uresničenja - Drugi tekmovalci nas skoraj dohitevajo.

Primerov rabe skoraj v korpusu Fidaplus v vseh prenosnikih je nad 100 000, med njimi tudi (21) in (22) spodaj, kjer prvi označuje trajanje samostalnika, drugi pa glagol.

(21)

Od takrat, ko sva nehala, je dva meseca in pol. Hodila sva skoraj dve leti in pol.

(www.fidaplus.net; Nedeljski, 2001)

Objektivno pač moramo verjeti, da slovenskim policistom ni vseeno, če se jim že nekaj mesecev skoraj posmehujejo, in da so res storili vse, da bi izsledili in prijeli napadalca ali napadalce na novinarja. (www.fidaplus.net; Dnevnik, 2001)

V govornem prenosniku najdemo le 389 primerov, kjer gre spet za določanje samostalnika (primer (23)) ali glagola (primer (24)) oziroma prislova (primer (25)). 
(23)

Kar zadeva levo sredinsko opcijo v Italiji, se mi zdi, da je podatek, da smo se vsi Slovenci, bi rekel skoraj brez razlike znašli v tej fazi, znotraj te želje, da bi nam ta opcija dala več pozornosti, ker slutimo in razumemo in vidimo, da je tam mogoče to doseči, medtem, ko na drugi strani nimamo kaj iskati, da je to tudi en podatek, ki ga velja podčrtati. Samo to. (www.fidaplus.net; DZ 1995)

Sedaj sem že skoraj pozabila, kaj sem hotela replicirati, ampak se bom spomnila, brez skrbi. Gospod Podobnik nam je povedal, kako revizije potekajo. (www.fidaplus.net; DZ 1995)

(25)

Drugič, jaz sem bil tudi na sestanku s sindikati Splošne plovbe, s sindikalisti Splošne plovbe in moram reči, da so izjemno energično, skoraj nasilno zahtevali, da se v ta zakon vključi tudi lastninjenje delavcev, da se jim omogoči participacija pri lastninjenju lastnega podjetja, ker seveda imajo priložnost se lastniniti s svojimi lastninskimi certifikati kjerkoli je to možno, ampak ne pa v domačem podjetju, ker se z današnjim dnem, če sprejmemo zakon, podržavi in zaradi tega oni potem ne morejo vlagati v svoje podjetje in iščejo potem poseben primer, se pravi, da naredimo izjemo v zakonu in to izjemo podpiram. (www.fidaplus.net; DZ 1995)

Skoraj po Ducrotu (po analogiji s francoskim presque) označuje argumentacijski prag, vendar ne v vseh primerih. Za členke, ki imajo v sebi »argumentacijski prag «, velja, da na ravni določenih zaključkov niso možna enaka nadaljevanja. Pri argumentaciji se skoraj in že izenačita glede sklepov, ki jih lahko potegnemo iz argumentov, medtem ko še ostaja na nasprotnem polu. Naj zopet citiramo Ducrotov primer $^{31}$ spodaj pod številko (26):

(26)

Dépêche toi - le diner est presque prêt

*Dépêche toi-le diner n'est pas tout a fait prêt

Prevod bi se glasil (vidimo, da druga varianta primera (26) ni argumentacijsko sprejemljiva, čeprav gre pomensko za sinonima.

Pohiti, večerja je skoraj pripravljena.

*Pohiti, večerja še ni pripravljena.

${ }^{31} \mathrm{O}$. Ducrot, Opérateurs argumentatifs et visée argumentative, Cahiers de linguistique française (1983) 5, 165 . 
$\mathrm{Na}$ enak način kot s skoraj poteka navezava z že:

(27)

Pohiti, večerja je že pripravljena.

Lahko pa še in skoraj zahtevata isti način argumentacije, medtem ko že zahteva drugačne argumente: Ducrotov primer ${ }^{32}$ je tako Le tonneau estplein - le tonneau est presque plein (sod je poln, sod je skoraj poln). Tu prag ni dosežen, saj sta možna tako (28) kot (29):

\section{(28)}

Sod je skoraj poln, ni več treba natakati.

Sod je že poln, ni već treba natakati.

Sod še ni poln, natoči še malo.

Sod je skoraj poln, natoči še malo (še malo se potrudi).

Argumentacija v jeziku torej ni nekaj splošno veljavnega, ampak je v veliki meri odvisna tudi od konteksta situacije in govorčeve interpretacije lete. Skoraj, ki označuje stanje blizu končne stopnje, je lahko usmerjen tako proti še malo je do konca kot končano je, ne glede na slovenski rek, da skoraj še nikoli ni zajca ujel.

Kàr kot operator za visoko vrednost je bilo v korpusu Fidaplus z obstoječimi orodji nemogoče ločiti po besednovrstni oziroma funkcijski pripadnosti od sinonimnega oziralnega zaimka. Med 100000 pojavitvami v pisnih in $6609 \mathrm{v}$ govorjenih besedilih je prevladoval oziralni zaimek $k a r$.

$K \grave{a}$ po SSKJ ima naslednje vrednosti:

1. poudarja intenzivnost dejanja - Kar čakajo, da planejo po njem.

2. krepi pomen prislovnega izraza - Mnenje je spremenil kar čez noč.

3. s presežnikom izraža najvišjo možno mero - Prizadevanje za kar najbitrejši podpis pogodbe.

4. izraža rahlo omejitev - Dekle je kar prikupno.

5. izraža nepričakovanost, neutemeljenost - Zakaj si kar obmolknil?

6 izraža spodbudo, poziv - Kar vstopi, kar brez skrbi bodi.

Pog. ekspr. - Kar tako!

Operator kar je v korpusu Fidaplus nastopal v funkcijah poudarjanja prislova v povedkovniški zvezi (primer (30)) in samostalniške besede (pri-

${ }^{32}$ O. Ducrot, n. d., 166. 
mer (31) in (32)). V tej vlogi je argumentacijska vrednost izreka, ki ga določa kar, usmerjena proti visoki stopnji.

Spoštovani zbor! Jaz mislim, da so stvari kar precej jasne. Najmočnejša stranka se zavzema za to, da ne bi v parlamentu potrjevali članov Sveta RTV, tiste manjše se zavzemajo za to, da bi. Očitno je, da bi najmočnejša stranka rada imela večino v Svetu RTV, zato pa naj bi bila odgovorna civilna družba, ne pa najmočnejša stranka. (www.fidaplus.net; 1994)

(31)

Veste gospod Jagodnik, znano mi je, vam je tudi znano, da je bilo kar nekaj polemik, tako na Svetu RTV, kot na drugih mestih o nekaterih lastninskih razmerjih, o nekaterih programih Radia Maribor. DZ (www.fidaplus. net; 1994)

Če bomo mi pomanjšan parlament spraviliv te okope, bodo seveda ti okopi med Svetom RTV in programskimi delavci, taki kot so, na škodo strokovnosti. In ta naša televizija potrebuje, da se ne bo kar naprej »dogajala«, tako kot se dogaja, kot smo slišali prej iz predgovornega nastopa - potrebuje torej tak način uravnavanja Sveta, kot nam ga ponuja vladni amandma. Hvala. (www. fidaplus.net; DZ 1994)

V primerih (33), (34) in (35) kar določa glagol, vendar spominja na pomen 5. oziroma 6. iz SSKJ, kjer gre bolj za členkovno, poudarjalno rabo.

KAR DOGAJA SE MI. (www.fidaplus.net; Ameriška pita, Poroka) (34)

NE, PROSIM. KAR POVEJTE, (www.fidaplus.net; Bridget Jones - Na robu pameti)

KAR ODVLECI ME. (www.fidaplus.net; Bridget Jones - Na robu pameti) $\mathrm{V}$ primeru (36) najdemo celo komentar izrekanja:

Mislim pa, da moramo biti toliko realni in trezni, če smo že pri sprejemu zakona spregledali nekaj stvari, da sedaj v tej fazi, ko je skupina poslancev pohitela in predlagala spremembo tega zakona, da naredimo čim bolj realno tem pogojem, kakršni so, in ne silimo lastnih sodržavljanov v nezakonitosti - da povem kar pošteno. Hvala. (www.fidaplus.net, Državni zbor 1994) 


\section{VSAJ IN TUDI}

Oba členka oziroma operatorja, $v s a j$ in tudi, imata dodajalno vlogo in prav tako stopata $\mathrm{v}$ nasprotja: prvi predstavlja minimalni pogoj, ki zadovolji govorca in naslovnika, drugi pa več kot je običajno, visoko stopnjo oziroma dodajanje.

\section{$V_{s a j-\mathrm{v} S S K J}$}

1. izraža omejevanje na najmanjšo količino ali mero - Tukaj sta možni vsaj dve poti.

2. izraža omejenost na določen stavčni člen - Kmalu bo prišel. Vsaj obljubilje.

\section{3. zastarelo saj-Vsaj ste me včeraj videli.}

$V_{s a j}$ - nasprotno od tudi - sporoča, da se je zgodilo le to, kar se opisuje, in to je že neka najmanjša možna zadovoljiva varianta. Med govorjenimi besedili v korpusu Fidaplus je bilo 1200 pojavitev vsaj. Pojavljal se je v odnosu do katerega koli dela izreka. V primeru (37) gre za samostalniški besedi (najprej doktorat, potem fakulteta), kjer s primerjavo med obema ter operatorjem vsaj izjavljalec kaže na velik kvalitativni razkorak med obema gospodoma.

Torej to, da se je izza tega pulta zadnjič gospod Pučnik prijavil kot psihoanalitik, to je dovolj čudno. Da se je kot psihoanalitik sedaj kot njegov učenec pojavil gospod Lenarčič, katerega izobrazba je še nekoliko bolj oddaljena od izobrazbe gospoda Pučnika, no, ampak gospod Pučnik ima vsaj doktorat, ko bi gospod Lenarčič vsaj fakulteto naredil, bi mu jaz zaupal, da se morda loti kakšnega takšnega, ne tako zahtevnega, ampak podobnega posla. Hvala lepa. (www.fidaplus.net; Seja državnega zbora RS, 1994)

V nadaljevanju vsaj določa glagol (primera (38) in (39)) in uvaja komentar izrekanja:

Hvala lepa. Gospod Kopše, jaz ne bi rad z vami polemiziral, toda kot je vsem znano, je bil zakon o sanaciji TAM-a sprejet marca leta 1995. Poročilo, o katerem vi govorite, se nanaša na situacijo pred tem, na leto 1994, vsaj tako tu piše, in po tej plati menim, da - in pa hkrati je to poročilo v Državnem zboru in se je vsakdo, ki je imel voljo, lahko z njim seznanil - se ne more nanašati na to, kar je zdaj v proceduri. (www.fidaplus.net; Seja državnega zbora RS, 1995) 
(39)

To ni tako majhen denar. Jasno je, da mora ta država vedeti, kaj bo zaradi plačevanja teh starih grehov, za katere niti nismo kaj prida krivi, vsaj tako zatrjujete, čemu se bomo morali odreči? To je eno temeljnih vprašanj. (www.fidaplus.net; DZ 1995)

$\mathrm{V}$ primeru (39) lahko iz vsaj izpeljemo »Moj argument je posredno podprt z vašim, ko pravite...«

Tudi pomeni dodajanje ideje, da se je zgodilo še nekaj poleg tega, kar opisuje pridevnik, samostalnik, prislov ali glagol.

Po SSKJ tudi prisl.:

1. izraža razširitev veljavnosti trditve na istovrstni stavčni člen ali dodajanje, navezovanje - Ni samo lepa, je tudi pametna.

2. stopnjuje povedano $z$ dodatno močnejšo ali nepričakovano trditvijo - Vsemu se je moral odpovedati, tudi upanju.

3. ekspr., v nikalnih stavkih poudarja zanikanje - Takih stvari tudiv sanjah še ni videl.

4. ekspr., izraža podkrepitev trditve - Presneto, se pa tudi bojiš.

5. v vezniški rabi - ne samo, ampak tudi - Ni samo govorila, ampak tudi delala.

6. v vezniški rabi, v dopustnih odvisnih stavkih, navadno v zvezi s če, kakor, ko za izražanje dejstva, kljub kateremu se dejanje nadrednega stavka uresniči - Tudi če bi poznali vse okoliščine, bi se težko odločili.

Pri tudi zabeležimo 100000 pojavitev v vseh prenosnikih (čeprav 1\% pokaže 58 in še nekaj tisoč), ${ }^{33}$ npr. primer (41), v samem govornem prenosniku pa 19609.

(41)

Tudi viceguverner Narodne banke Črne gore Milojica Dakić ni o tem nič povedal, ugotovil je le, da njegova banka ni dobila vabila in tudi ne informacije o tem, da je v Beogradu sestanek guvernerjev, to pa je po njegovem mnenju popolnoma nelogično, saj bi morali biti na sestanku tudi predstavniki uradnih črnogorskih denarnih oblasti. Zadnje čase je v Črni gori čedalje pogosteje slišati trditve bančnikov, gospodarstvenikov in vladnih predstavnikov, da bi se morala tudi ta republika čim prej vključiti v delitev premoženja. (www.fidaplus.net; Delo, 13. 12.2000)

${ }^{33}$ Pri zelo frekventnih besedah se v korpusu Fidaplus pokaže številka 100000. 
Primer (41) kaže na pretirano rabo tudi, predvsem v kombinaciji s samostalnikom. Primeri iz pisnega prenosnika zgoraj se ne razlikujejo bistveno od govornega (42), kjer se tudi pojavi v kombinaciji s samostalnikom (tudi na zavarovalnicab), zaimkom (tudi on, jaz tudi), in glagolom (tudi bi rad vedel), vse v okviru enega izreka.

Ali bodo imele pravice vpogleda in na osnovi tega bomo mi padli po nekih tabelah v tako in tako skupino in na tej osnovi bomo potem tudi naprej plačevali. Jaz tudi opozarjam na to, da to niso majhne stvari. Če računamo, da začnemo bolehati tam pri 50-ih letih, pomeni, da bo potem polovica ljudi v nekih kartotekah tudi na zavarovalnicah, kjer bodo nas razvrščali in na ta način bomo tudi plačevali. Zanima me, če bom jaz padel, zdaj recimo, če zavarujem hišo, rečejo toliko in toliko bi moral plačati in jaz rečem, ne plačam toliko, ampak manj plačam, ali se bom po novem lahko, če bom ne vem kako rizičen, ali se bom lahko zavaroval za manjšo vsoto ali ne. Torej tudi to bi rad vedel, ali bo isti princip kot pri zavarovanju nekih materialnih stvari ali bo pri ljudeh ista zadeva.(www.fidaplus.net; Državni zbor 1996)

Tudi deluje tudi kot veznik (primer (43)):

Mislim, da bistveno za to, da je tožilec neodvisen, je to, da dela lahko neodvisno, to se pravi, da mu je z zakonom zagotovljena neodvisnost, da mu je zagotovljena prava vloga v postopku. In zavzemali smo se tudi, če se spomnite pri kazenski zakonodaji in postopku, da je tožilec stranka v postopku, ne pa več tisti poklicani od države, ki ščiti državo pred državljani. Tako, da težko zdržijo sedaj ti argumenti predlagateljev zakona, da je tožilec odvisen od Vlade. (www.fidaplus.net; DZ 1995)

\section{PAČ IN SPLOH}

Brez bistvenega vpliva na vsebino, ki jo določata, sta pač in sploh odvisna predvsem od govorčevega namena, da bo izpostavil, poudaril določen del izreka.

\section{Pač v SSKJ:}

1. izraža zadržanost, precejšnjo verjetnost - Kozarček bi se pačprilegel.

2. za vprašalnim zaimkom ali prislovom: poudarja ugibanje $-K d o j e$ pačta tujec.

3. izraža sprijaznjenje z danimi dejstvi - Dela, kot je pačnavajen. 
4. z nasprotjem v drugem stavku - izraža omejevanje, dopuščanje - Ni priden delavec. Pač, priden je, samo neroden. pokonci.

5. uvaja zavrnitev s popravkom - Nas nisi pričakoval? Pač, zato sem pa

6. v vezniški rabi: za uvajanje nove trditve namesto prej s pridržkom zanikane - Tega ne trdi naravnost, pačpa po ovinkih.

Za pač je v korpusu Fidaplus 2617 najdenih zadetkov, od tega 40 zadetkov na začetku izreka. ${ }^{34}$

$P a c ̌$, ki je lahko enosmeren ali dvosmeren, običajno poudarja argument ali del argumenta, ki sledi. Enosmeren je v primerih (43), (44) in (45), kjer poudarja samostalnik, prislov ali glagol.

Spoštovani gospod podpredsednik, kolegice in kolegi! Zdaj, če bi tudi o tej točki dnevnega reda želeli tako razpravljati, kot je prej gospod Lavrinc, potem bi rekli, da je to zakon, ki ga je Liberalna demokracija vložila tik pred volitvami v proceduro, zato da bi paćv Trbovljah dobila veliko glasov. O vsakem zakonu, ki je bil vložen pred volitvami, bi lahko razpravljali na tak način. Vendar gre tukaj za resno dilemo. (www.fidaplus.net; DZ 1994)

Predlagam, da se predlagatelja amandmaja dobita skupaj s predlagateljem zakona, da pripravite amandmaje tako, da bomo o njih lahko glasovali tako, kot menite, da je pač najbolje in da s tem predlogom potem seznanite Državni zbor, če se s tem strinjate. (www.fidaplus.net; DZ 1994)

Hvala. Pač komentiram stališča predstavnika Vlade. Torej, za zakon proti pranju denarja je v državi, kjer poteka proces, ko je stvar najbolj občutljiva, ni logike, da se ga sprejema po maksimalno upočasnjenem postopku in je edino smiselno, da se ga sprejme po hitrem postopku, kar smo tudi predlagali, in upam, da se bo sedaj tudi zgodilo. (www.fidaplus.net; 1994)

$\mathrm{V}$ primeru (46) pač uvaja komentar izrekanja:

Poslanec je dober samo takrat, ko je treba pritisniti na gumb. Tako je! Pač mi to priznate ali ne. (www.fidaplus.net; DZ 1998)

\footnotetext{
${ }^{34}$ Pozicija konektorja ali z veliko začetnico za končnim ločilom je lahko utemeljitev njegovega statusa konektorja (prim. M. Schlamberger Brezar, Les connecteurs en combinaison avec les marquers modaux: l'exemple du français et du slovène, Linguistica XL (2000),2). V korpusu Fidaplus se ta segment da izpostaviti pri iskanju, vendar pa žal način transkripcije razprav iz Državnega zbora ne daje garancije za njegovo ustreznost.
} 
Dvosmerno je $p a c ̌$ rabljen v kombinaciji s konektorjem ker (primer (47)):

Mi smo predlagali delitev člena, v kolikor pa člen ostane nespremenjen, v celoti tak, kot je, potem predlagamo to. Ker se amandma pod številko 1 nanaša samo na prvi odstavek, amandma pod številko 7 se nanaša na drugi in tretji odstavek, ker pač oba amandmaja samo širita določene pravice znotraj teh pravnih sredstev. (www.fidaplus.net; DZ 1994)

Pač za argumentacijo pomeni izpostavljanje, poudarjanje, včasih je govorec s to funkcijo tako prežet, da prihaja do pretirane rabe pač in se zdi kot mašilo. Drugi členek, ki deluje na ta način, je sploh. Po SSKJ sploh:

1. izraža splošno veljavnost povedanega - To so sploh znane besede.

2. izraža veljavnost za celoto v primerjavi z njenimi deli - Pred očmi nam ni posameznik, ampak človek sploh.

3. pog. ekspr., izraža obstajanje česa poleg že povedanega - Zahvaljujem se vam za požrtvovalnost, medsebojno razumevanje in sploh.

4. ekspr., izraža ugotovitev, spoznanje resničnega stanja - Splob mu delamo krivico.

/v vezniški rabi

/v medmetni rabi - Potepal sem se po mestu, obhodil obzidje, slikal v arhivu, sploh, nisem se dolgočasil.

5. nav. ekspr. navadno v vprašalnih, odvisnih stavkih poudarja pomen besede, na katero se nanaša - Kako je to sploh mogoče, sprašujem se, kaj sploh delam tukaj.

//v nikalnih stavkih poudarja zanikanje: Ponoči splob ne spi.

Za sploh v korpusu Fidaplus zabeležimo 977 pojavitev, in sicer v povezavi z glagolom (48) in kot komentar izreka (49). Primer (49) je zanimiv, ker je govorec z dodajanjem sploh želel še poudariti svojo zavezanost resničnosti trditve. Po teoriji modalnosti ${ }^{35}$ pa bi bila trditev brez rabe členka bolj zavezujoča.

(48)

Govori o stavbni pravici, vendar stavbno pravico nikjer v tem zakonu ne opredeljuje. Ne kako se do nje pride, ne kaj to sploh pomeni, tako da s tega vidika mislim, da je stvar pomanjkljiva. Navsezadnje bi lahko imeli ta institut stavbne pravice tudi za državljane. (www.fidaplus.net; 1996)

${ }^{35}$ F. R. Palmer, Mood and Modality, Cambridge 1986. 
(49)

Bom še za naprej, ker se mi zdi, da so nekatere razprave, kot da je bil naš predlog, čeprav je že mimo, ampak nisem hotel priti dol, da je bil to, da se črta možnost ocene davčne osnove. To sploh ne drži, ampak da se črtata dve točki, ki sta po našem mnenju problematični, ne pa, da se črta možnost, da bi davčni organ ocenjeval dohodek, pač pa dve točki, ki sta verjetno res problematični. (www.fidaplus.net; 1996)

V primeru (50) pa sploh nastopa kot povezovalec:

Toda niti Vlada za svoje modele še ni dala finančnih posledic. Tiste grobe ocene so popolnoma brez osnove. Sploh, če se izkaže, da teh stanovanj ne bo 10 tisoč, da bo verjetno na koncu največja številka okrog 3 tisoč. (www.fidaplus.net; 1994)

Predvsem primeri iz govorjenega korpusa Fidaplus kažejo, da je malo primerov splob in pačv diskurzu povezano z opisi iz SSKJ. Splob in pač delujeta kot argumentacijska operatorja, a ne toliko v službi poudarjanja argumenta kot poudarjanja govorčeve volje po poudarjanju, nemalokrat tudi samo kot mašili.

\section{SAMO, LE}

Samo in le delujeta kot izvzemalna členka, kot konektorja pa se združujeta $v$ dopustno-protivna argumentacijska gibanja. V obeh rabah sta tako rekoč sinonimna, seveda odvisno od posameznih primerov, vendar je le nekoliko bolj knjižen.

Le po SSKJ izraža:

1. izraža omejenost na navedeno - To je le en kos.

//ekspr., izraža popolno omejenost na navedeno dejanje, samo - Jaz se le čudim.

2. nav. ekspr., v zvezi s pa krepi nasprotje s prej povedanim - Vsega imajo, pa le niso srečni.

//nav. ekspr., izraža nepričakovanost trditve - Sempa le radoveden, kdo bo zdržal.

//v vezn. rabi, v zvezi le da: za omejevanje prej povedanega - Tudi v naši tovarni imamo iznajditelje, le da premalo.

3. navadno v zvezi s če: poudarja pogojnost - Plačal bi, če bi le mogel. 
4. navadno ekspr., za oziralnimi zaimki ali prislovi poudarja poljubnost, posplošenost - Kdor le more.

5. ekspr., z vprašalnim zaimkom ali prislovom - poudarja ugibanje Kaj si bo le mislil.

6. ekspr., izraža spodbudo, poziv - Le čakaj.

7. elipt., v zvezi z da, če izraža zadovoljnost, začudenje, zaskrbljenost Da ste le zdravi, če le ni hujšega.

8. navadno v zvezi kot le - izraža visoko stopnjo - Zvit kot le kaj.

Le s 1491 pojavitvami v korpusu Fidaplus v govornem prenosniku (od omejitve $100000 \mathrm{v}$ vseh prenosnikih) v večini primerov deluje kot operator; v primerih (51), (52), (53) spodaj se le navezuje na zaimke oziroma na prislov.

VEDO LE, KARJIM POVEŠ. (www.fidaplus.net; dramsko besedilo Ujemi me, če moreš)

Tudi sam bi podprl kakšen morda drugačen amandma na to isto temo, če bi ga le kdo vložil. (www.fidaplus.net; DZ 1998)

Argument Vlade, da v svetu ni normalno, da bi v takih skupinah sodeloval predstavnik opozicije, le težko zdrži. (www.fidaplus.net; DZ 1996)

$L e \mathrm{v}$ odnosu do samostalnika in glagola je prisoten v primeru (54) spodaj:

(54)

Agencija je v zadevi TAM raziskovala predvsem morebitno prisotnost tujih dejavnikov, vendar domneve ni mogla potrditi. Ugotovila je, da naj bi šlo le za nepravilnosti pri poslovanju podjetja, kar so takrat že raziskovali pristojni organi, kot so Agencija za plačilni promet Republike Slovenije, inšpekcijske službe in kriminalistična služba. Ker domnev o prisotnosti tujih dejavnikov Agencija ni potrdila in ni ugotovila, da bi šlo za njihovo organizirano dejavnost, usmerjeno v ogrožanje gospodarskih interesov države, ampak le za domnevne nepravilnosti pri poslovanju TAM-a, ki jih sankcionira kazenski zakon Republike Slovenije, je o tem marca leta 1995 le obvestila predsednika Vlade Republike Slovenije, saj zbrane ugotovitve niso terjale dodatnih ukrepov SOVE. Hvala lepa. (www.fidaplus.net; 1996) 
Nekaj primerov le se pojavi tudi v vlogi konektorja, vendar ločevanja na operatorje in veznike po korpusu ne moremo opraviti. Konektorska raba lahko pomeni vključevanje v stopnjevalno ali dopustno-protivno diskurzivno gibanje. Tak je primer (55) spodaj s konektorsko sekvenco ne le, ampak tudi:

(55)

Vlada meni, da so izjave gospoda Antona Drobniča take vrste, teže in narave,

da ne sodijo v današnje čase, saj so zaradi njih lahko prizadetih številni Slovenci, ki dan upora proti okupatorju praznujejo ne le kot državni, ampak tudi kot svoj praznik. (www.fidaplus.net; DZ 1998)

Samo - konektor in operator - šteje 5422 pojavitev v korpusu Fidaplus v govornem prenosniku. Samo operator oziroma členek po SSKJ:

1. izraža omejenost na navedeno - Zanj je pomembno samo delo.

//ekspr., izraža popolno omejenost na navedeno - Mi se samo čudimo, da toliko časa zdržiš.

2. ekspr., z velelnikom izraža spodbudo, poziv - Samo mirno!

//izraža grožnjo, svarilo - Samo počakaj!

3. z vprašalnim zaimkom ali prislovom - Samo kje bomo zdaj dobili zdravnika.

4. navadno v zvezi s če: poudarja pogojenost - Naj se igrajo, samo če ne bojo delali prevelikega brupa.

5. elipt., v zvezi z $d a$, če izraža zadovoljstvo, začudenje, zaskrbljenost Samo da se ji ni kaj zgodilo.

Prva raba je sinonimna z $l e .^{36}$

Samo določa samostalnik (omejevanje neke množice, izvzemanje - primer (56) spodaj, podobna je tudi raba v primeru (57)):

Sicer med vsemi cilji in tezami, ki jih ima program, in ki jih podpiramo, posebej izpostavljamo izobraževanje. Kajti ocenjujemo, da samo okoljevarstveno ozaveščeni državljani Slovenije bomo v bodoče sposobni tak program tudi realizirati. (www.fidaplus.net; 1999)

Hvala lepa. Malo repliciram gospodu ministru, ampak ne iz zlobe, ampak mogoče zato, da bomo nekatere stvari malo bolje razumeli. Okolje lahko po-

${ }^{36}$ Vezniška raba nakazuje na samo kot konektor - pogostejši od le. O konektorju samo podrobneje govorimo tudi v poglavju Toposi, konektorji in argumentacijska gibanja. 
skrbi samo za sebe, samo človeka ne sme biti zraven. Vsi se strinjamo, da lahko eno dolino zapremo, da ljudje ne bodo vanjo hodili; ni problem. Drevo, ki se posuši in tam segnije, pač tam segnije; divja žival... (www.fidaplus.net; Državni zbor 1999)

Spodnji primer (58) pa predstavlja, kaj se zgodi, če samo v diskurzu nadomešča tako operatorje kot konektorje: samo operator se nanaša na samo oseba (2 ponovitvi) in na prislovno zvezo samo bolj ali manj slućajno, samo konektor pa nastopa v zvezi ne samo, temveć tudi (stopnjevanje - 3 zaporedne ponovitve).

Mislim, da ne smemo človeka pojmovati pretežno niti kot delovno silo niti kot nekega prostonihajočega duha nekje, ki se pač v svetu samo bolj ali manj slučajno nahaja itd., temveč da je resnica nekje v sredini. Ne glede na različne akcente verjetno ne bomo mogli mimo dejstva, da opredelimo človeka predvsem kot samostojno osebo, ki je odgovorna za sebe, ne samo za svoje zdravje, za svoje ekološko okolje, ne samo za svoj napredek, ne samo za svoje finance itd., temveč tudi za ožjo in širšo skupnost - skratka, osebo z odgovornostjo. Odgovornosti pa ni mogoče opredeliti in zahtevati, če ne določimo tudi individualnosti in samostojnosti, ni odgovornosti brez osebne svobode, ni odgovornosti brez posebnih kompetenc te osebe. Samo oseba, ki je v sebi svobodna, ki teži po svobodi, ki je pripravljena reči ne, ki ima neko osnovno civilno korajžo, če hočete, ki ima nek osnovni pogum, samo ta oseba je sposobna tega, kar imenujemo odgovornost. Tu imamo z neko, bi rekel, v starih časih bi bili rekli z neko dialektiko, z nekim prepletanjem dveh polov, kjer se pravzaprav svoboda opredeljuje s pojmi obvez in ob pojmu obveze; kategorije obveze ljudi ali dolžnosti ljudi se opredeljujejo s pojmi ali pa atributi svobode. (www.fidaplus.net; DZ 1995)

Pojavitev samo na začetku izreka, takih primerov je 665, bi morda lahko kazala na konektorsko vlogo, vendar pregled ne da natančnega rezultata, med zadetki so tako operatorji kot konektorji (primer (59) spodaj):

Mi pa se moramo zavedati in postaviti zahtevo vladi oziroma vsem resorjem, ki jih vlada pokriva, da mora načelo varovanja okolja slediti vsem programom na vseh ravneh razvoja Slovenije; tako na področju gradenj cest, področju energetike in ostalih področjih, s katerimi se dnevno srečujemo. Samo na tak način je možno pričakovati, da bo po sprejemu ta program imel tudi svoje učinkovito nadaljevanje. (www.fidaplus.net; DZ 1999) 
Samo in le kot členka poudarjata izjemnost, edinstvenost izvzetega dela. Samo in le sta se v analizi primerov v korpusu izkazala v izraziti vlogi operatorjev - povezovalske oziroma konektorske vloge je bilo manj, podrobneje pa je obravnavana v naslednjem poglavju.

\section{Sklep}

Ali je s funkcijskega in besednovrstnega stališča upravičeno trditi, da $\mathrm{v}$ slovenščini členki obstajajo, pravzaprav niti ni važno, ne glede na to, da jih SSKJ ne priznava. Dejstvo je, da je ta kategorija precej heterogena in da združuje različne skupine operatorjev oziroma tudi konektorjev, ki pa jih v skupini sami družijo podobne lastnosti. To je predvsem odnosna komponenta do besedila, ki ga določajo, in je izraz govorčeve volje, da ta del besedila poudari ali kako drugače označi.

Iz tega izhaja, da so členki kot nalašč za izražanje argumentacije v jeziku. Vprašali smo se, kateri od členkov lahko delujejo kot operatorji v ducrotovskem smislu. To so vsekakor poudarni členki, vendar kot pripadniki heterogene kategorije ne delujejo povsem enovito - ne moremo jih enoznačno razdeliti med operatorje in konektorje. Najraje so kar oboje - odvisno od sobesedila in konteksta. Pri opredelitvah smo si pomagali z definicijami v Slovarju slovenskega knjižnega jezika (SSKJ) in analizirali avtentične primere $\mathrm{v}$ korpusu Fidaplus. Problem opisov v SSKJ izhaja iz dejstva, da so členki besede $z$ močno pragmatično dimenzijo, predvsem v govorjenem jeziku, in je njihov pomen težko ločiti od širšega konteksta. To se vidi tudi pri opisih členkov v SSKJ kakor tudi v Toporišičevi slovnici (primer saj npr. po pomenu sega od protivnega do grozilnega členka). Raba, ki je podana v SSKJ, ni dovolj dekontekstualizirana, zato so opisi na eni strani tako dolgi (npr. že), po drugi strani pa realna raba, kot je odslikana v korpusu Fidaplus, ne daje zadetkov za vse primere, ki so opisani v SSKJ. Od tod razhajanje pri opisih.

Nam morda lahko teorija argumentacije v jeziku ponudi pomoč pri enotni opredelitvi slovenskih členkov? Pregled nekaj pogostejših slovenskih členkov, predvsem tistih iz razreda »poudarnih «, v luči Ducrotove in Anscombrove teorije argumentacije v jeziku pokaže, da delujejo kot argumentacijski operatorji. A ker se v govorjenem diskurzu, kot smo lahko videli v primerih, nit argumentacije včasih zgubi in ostanejo samo še poudarki, členki delujejo kot mašila, kar se je pokazalo predvsem pri sploh in pač. Zanimivo je, da večina teh členkov lahko deluje tudi kot konektorji in se vključujejo v argumentacijska gibanja. $\mathrm{O}$ tem bo sicer več povedanega v nadaljevanju, pa vendar lahko sklenemo poglavje z ugotovitvijo, da so členki nosilci argumentacije v jeziku bodisi kot konektorji, bodisi kot operatorji. 


\section{In - veznik in konektor}

\section{Razmejitev pojmov konektor in veznik}

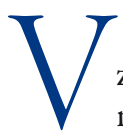

zvezi z in, pa tudi drugimi vezniki in povezovalci na eni strani uporabljamo poimenovanje povezovalec ali konektor, na drugi strani pa veznik in vezniška beseda. Nekateri vezniki so lahko tudi povezovalci, drugi ne morejo biti nikoli, na primer če in da. Zakaj prihaja do tega, kako lahko to trdimo?

Veznik in vezniška beseda sta pojma, vezana na besedno vrsto oziroma skladenjsko funkcijo, medtem ko so povezovalci ali konektorji semantični in pragmatični zaznamovalci, ki delujejo v diskurzu. Po skladenjski opredelitvi ${ }^{1}$ povezovalci delujejo tako na ravni izreka (oziroma propozicije) kot izrekanja, vezniki in vezniške besede pa se pojavljajo v izreku samem. Povezovalce se od veznikov da ločiti z različnimi testi, ki ločujejo povezovalce ali konektorje, ki se pojavljajo na izrekanjski ravni, od semantičnih povezovalcev oziroma operatorjev, ki delujejo na nižji ravni. ${ }^{2} \mathrm{~V}$ primeru in je prav to delovanje odločilno za odločanje, ali je in uporabljen kot veznik ali kot povezovalec oziroma konektor. Samo v vlogi konektorja ima lahko potencialno argumentacijsko vlogo, kot jo predvidevata Ducrot in Anscombre. ${ }^{3}$

\footnotetext{
${ }^{1}$ M. Schlamberger Brezar, Les connecteurs en combinaison avec les marquers modaux: l'exemple du français et du slovène, Linguistica XL (2000), 2.

${ }^{2}$ N. d.

${ }^{3}$ J.-C. Anscombre, O. Ducrot, L'Argumentation dans la langue, Bruselj 1983.
} 
O povezovalcih smo pisali že precej izčrpno ${ }^{4}$ in v nadaljevanju povzemamo že večkrat predstavljene ugotovitve.

Poimenovanje povezovalec (angleško connective, connector; francosko connecteur) ${ }^{5}$ se pri nas sloveni tudi kot konektor in povezovalnik. ${ }^{6}$ Izvira iz logike, iz propozicijskega računa, kjer je določen z resničnostnimi vrednostmi. Logični povezovalci ali konektorji so prilagojeni formalnim jezikom in imajo z naravnimi jeziki le oddaljeno povezavo, zato so pragmatične analize to delitev skušale presegati.?

V jezikoslovju je v okviru strukturalistične distribucionalistične slovnice $\mathrm{v}$ sedemdesetih letih prejšnjega stoletja povezovalce prvi omenjal Harris, in sicer kot dvomestne operatorje. ${ }^{8}$ Skladenjsko jih je razložil kot priredne, podredne in primerjalne veznike. Zanimanje za povezovalce je naraslo $\mathrm{v}$ začetku osemdesetih let $\mathrm{v}$ okviru pragmatičnega jezikoslovja, ko so se $\mathrm{v}$ jezikoslovju pojavile potrebe po ustreznih modelih, ki bi služili za raziskovanje avtentičnih diskurzov, predvsem pa v okviru teorije relevance ${ }^{9}$ , ki povezovalce razlaga predvsem v odnosu do konteksta. Prvi je o pragmatičnih povezovalcih spregovoril T. Van Dijk. ${ }^{10}$ Semantične povezovalce ali konektorje je od pragmatičnih ločil na osnovi dveh primerov:

(60)

Včeraj smo šli v kino, potem pa še na pivo.

(61)

Zakaj Petra še ni? Sploh pa, kje si bil vso noč?

\footnotetext{
${ }^{4}$ M. Schlamberger Brezar, Zgradba pogajalske komunikacije, magistrska naloga, Ljubljana 1996;M. Schlamberger Brezar, Vloga povezovalcev v diskurzu, v: I. Štrukelj (ur.), Jezik za danes in jutri, Zbornik referatov na II. kongresu Drustva za uporabno jezikoslovje, Ljubljana 1998; M. Schlamberger Brezar, Les connecteurs en combinaison avec les marquers modaux: l'exemple du français et du slovene, Linguistica XL (2000), 2.; M. Schlamberger Brezar, Vloga povezovalcev v govorjenem diskurzu, Jezik in slovstvo 52 (2007), 3/4, 21-32.

${ }^{5} \mathrm{~V}$ tem delu uporabljamo oba izraza - povezovalec in konektor.

${ }^{6}$ V. Gorjanc, Konektorji v slovničnem opisu znanstvenega besedila, Slavistična revija 46 (1998), 4, 367-388; M. Schlamberger Brezar, Vloga povezovalcev v diskurzu, v: I. Štrukelj (ur.), Jezik za danes in jutri, Zbornik referatov na II. kongresu Društva za uporabno jezikoslovje, Ljubljana 1998.

${ }^{7}$ T. A. Van Dijk, Studies in the pragmatics of discourse, Paris, New York 1981; E. Roulet et al., L'Articulation du discours en français contemporain, Bern 1985; J. Moeschler, Argumentation et conversation. Éléments pour une analyse pragmatique du discours, Paris 1985.

${ }^{8}$ Operator je v logiki definiran kot enomestni ali dvomestni - enomestni (npr. negacija) delujejo na jedro, ki mu pripadajo, dvomestni (npr. konjunkcija) pa dve jedri povezujejo v enoto. Prim. J. M. Luscher, Les marques de connexion: des guides pour l'interprétation«, v: J. Moeschler et al. (ur.), Language et pertinence, Zbirka Processus discursifs, Nancy 1994.

${ }^{9}$ D. Sperber, D. Wilson, Relevance - Communication and cognition, Oxford 1986.

${ }^{10}$ T. A. Van Dijk, n. d. (članek iz leta 1979).
} 
V prvem primeru povezovalec pa izraža odnose med dejstvi, in sicer časovno sosledje, ki je osnova za koherentno besedilo. Predstavlja semantično vez v okviru propozicij in je torej semantični povezovalec. $\mathrm{V}$ drugem primeru pa gre za rabo med različnimi govornimi dejanji (to je predvsem razvidno, kadar povezovalci zavzemajo začetno mesto $\mathrm{v}$ izreku) in posledično za pragmatično rabo.

Podobno je v okviru svoje integrirane pragmatike povezovalce označil O. Ducrot s sodelavci. ${ }^{11}$ Poudaril je razliko med jezikovnimi segmenti, ki jih povezujejo povezovalci, in bitnostmi oziroma semantičnimi vsebinami, ki so predmet povezave. Na primeru mais/ampak je dokazoval, da prvih in drugih ni možno enačiti. Interpretacija spodnjih primerov poteka takole (v primeru (62) gre za povezave med jezikovnimi segmenti, v primeru (63) pa za povezave med semantičnimi vsebinami):

Pierre est là, mais Jean ne le verra pas.

Peter je prišel, ampak Janez ga ne bo videl.

(63)

Pierre est là, mais ça ne regarde pas Jean.

Peter je prišel, ampak to se Janeza ne tiče.

Povezovalci torej uvajajo semantična in pragmatična razmerja med deli izrekov in so pojem analize diskurza. Definicija veznika in vezniške besede pa izvira iz skladnje: po Toporišiču sta veznik in vezniška besedna zveza definirana besednovrstno in funkcijsko. Veznik ${ }^{12}$ je »besedna vrsta za izražanje prirednih razmerij med sestavinami besednih zvez ali med stavki ... ali za izražanje podrednih razmerij med stavki.« Vezniška beseda ${ }^{13}$ pa je vsaka »beseda (besedna zveza), ki lahko povezuje besede, besedne zveze ali stavke. To je predvsem veznik, členek, vprašalni zaimek, oziralni zaimek ...« V funkcijski definiciji vezniške besede niso zajete vse funkcije, ki jih imajo povezovalci: v zgornji definiciji manjka predvsem funkcija zaznamovanja medpovednih in nadpovednih odnosov, torej tipična diskurzivna funkcija, zato se nam zdi smiselno pojem povezovalca definirati in mu določiti področje delovanja tudi v slovenščini.

M. Piot v uvodu v 77. številko revije Langue française poimenovanje povezovalec uporablja za priredne in podredne veznike. ${ }^{14} \mathrm{Na}$ ta način de-

\footnotetext{
${ }^{11}$ O. Ducrot et al., Les mots du discours, Paris 1980.

${ }^{12} \mathrm{~J}$. Toporišič, Enciklopedija slovenskega jezika, Ljubljana 1992, 351.

${ }^{13}$ J. Toporišič, n. d., 352.

${ }^{14}$ M. Piot navaja: »Les études qui suivent utilisent le terme dans l'acceptation restreinte de conjonctions de subordination et de coordination. Elles se caractérisent par l'attention qu'elles
} 
finirani povezovalci so glede na prejšnje ugotovitve in definicije operatorji. ${ }^{15}$ Obravnavanje veznikov pod imenom povezovalci ni funkcijsko utemeljeno. M. Piot na navedenem mestu tudi poudarja, da so do sedaj povezovalci nastopali predvsem $\mathrm{v}$ razpravah $\mathrm{z}$ argumentacijskim in pragmatičnim navdihom. Tam je bil poudarek na odnosih med nastopajočimi v diskurzu in na sporazumevalnih namenih, ki jih glede na govorca razkriva ta ali oni element, imenovan povezovalec. V naši definiciji bomo poleg skladenjskih upoštevali tudi pragmatične in argumentacijske elemente.

Riegel, Pellat in Rioul v okviru Grammaire méthodique du français (1994) obravnavajo veznike kot del skladnje oziroma samostojno besedno vrsto, ki je del zložene povedi. Povezovalci pa so del poglavja La structuration du texte, ki spada v večjo enoto Grammaire et communication. Med obema pojmoma ni nobene povezave.

Za povezovalce je podana naslednja definicija: »Povezovalci so element $i$ vezave med propozicijami ali množicami propozicij; prispevajo k oblikovanju besedila in zaznamujejo logično-semantične odnose med propozicijami ali med sekvencami, ki jih sestavljajo. $\ll^{16}$

Zgornji definiciji manjkajo določeni elementi: propozicija sama po sebi ne pokriva vseh možnih navezav povezovalcev. Povezovalci se včasih vežejo na sam kontekst (primer (64)).

\section{(64)}

Kontekst: A in B prideta domov z izleta in vidita, da ima sin zabavo:

A: A, ZATO ni hotel iti z nama!

Po Nølkeju ${ }^{17}$ vezniki, ki delujejo na ravneh, nižjih od ravni povedi, niso povezovalci. To prepričanje je del tradicije v védenju o povezovalcih. Tako tudi redko srečamo dela (nasprotni primer predstavljajo jezikoslovci, ki so objavljali v okviru Langue française 77, 1988), ki kot povezovalce obravnavajo podredne časovne veznike $k d a j, \check{c} e$, da in podobno ter priredna veznika in ali ali v funkciji veznikov med samostalniškimi besednimi zvezami.

portent à la description de l'ensemble des propriétés linguistiques des deux phrases reliées par un connecteur.« M. Piot, Langue française (1988), 6.

${ }^{15}$ Dejansko M. Piot in ostali ne ločujejo med funkcijami operatorjev in povezovalcev, saj je za povezovalce podana naslednja definicija (Piot, n. m.): »les connecteurs sont des opérateurs dont la principale et la subordonnée sont les arguments«.

${ }^{16} \mathrm{~V}$ originalu se definicija glasi: $\gg$ Les connecteurs sont des éléments de liaison entre des propositions ou des ensembles de propositions; ils contribuent à la structuration du texte en marquant des relations sémantico-logiques entre les propositions ou entre les séquences qui le composent.« M. Riegel, J. C. Pellat, R. Rioul, Grammaire méthodique du français, Pariz 1994, 617.

${ }^{17}$ H. Nølke, Linguistique modulaire: de la forme au sens, Louvain, Pariz 1994, 121. 
Dik dodaja, da se povezovalci pojavljajo v vzorcih naslednje oblike (pri$\operatorname{mer}(65)):^{18}$

Prejšnji izrek(i). Povezovalec, nov izrek.

Glavna naloga povezovalcev je, da povezujejo nov izrek s prejšnjim(i) in hkrati določajo semantični in pragmatični odnos med njima(i). Tudi pri analizi spontanih govorjenih besedil se je pokazalo, da je povezovalec navadno na prvem mestu v novem govornem posegu, ${ }^{19}$ kar pomeni, da deluje $\mathrm{v}$ okviru izmenjave in uvaja govorni poseg, kakor bo v nadaljevanju prikazano s primeri iz korpusa.

Dik postavi povezovalce v pragmatični okvir, saj pravi: »povezovalcev ne gre enačiti s prirednimi vezniki, ki delujejo medstavčno, celo, če so semantično identični ${ }^{20}$ (naš prevod). S tem opozarja na večpomenskost povezovalcev. Le-to lahko prikažemo s primeroma (66) in (67): v primeru (66) veznik ampak nastopa v vlogi semantičnega, v primeru (8) pa v vlogi pragmatičnega povezovalca:

(66)

A: Račun za prevoz bi bilo treba še preverit, da ne bi znašal za potne stroške, ampak samo za stroške prevoza, kolikor je ... cena za bencin. ${ }^{21}$

(67)

A: No, štipendij ni in ljudje nimajo denarja in mi moramo ponudit en štirinajstdnevni tečaj, oziroma kar dva, zato ...

B: $\mathrm{Ne}$, ampak to ni argument tukaj, bolj je, da časovno, da nekateri, recimo, kajstvem, lansko leto je bil en poslovnež, ki ni mogel prvih štirinajst dni ...22

$\mathrm{V}$ primeru (66) povezovalec ampak veže dve neodvisni propoziciji v okviru ene povedi oziroma izreka, v primeru (67) pa uvaja celoten odgovor B. Obakrat uvaja nasprotje glede na prvi del. Glede na semantično naravo povezovalca ampak lahko potegnemo naslednje sklepe: pri (66) lahko zaključimo, da so potni stroški večja postavka kot stroški prevoza, da pa

\footnotetext{
${ }^{18}$ S. C. Dik, The Theory of Functional Grammar, Part II: Complex and derived constructions, ur. K. Hengeveld, Berlin, New York 1997, 440.

${ }^{19}$ M.A. Morel, L. Danon-Boileau, La grammaire de l'intonation: Exemple du français, ParisGap 1998.

${ }^{20} \mathrm{~V}$ izvirniku: »Connectors are not to be equated with coordinators, which function intra-clausally, even if they are semantically identical.«S. C. Dik, n. d.

${ }^{21}$ M. Schlamberger Brezar, Zgradba pogajalske komunikacije, magistrska naloga, Ljubljana 1996 (primer: Pogajanje o ceni popravila računalnika).

${ }^{22}$ N.d. (primer: Pogajanje o organizaciji jezikovnega tečaja).
} 
se jim bo govorec odrekel, da s tem ugodi zahtevi po soglasju. Povezovalec ampak deluje med dejanskimi stanji. V primeru (67) pa govorec z rabo povezovalca ampak zavrača okvir argumentacije sogovorca-naslovnika $\mathrm{A}$ in uvaja novega. Povezovalec ampak deluje na ravni izrekanja, in sicer v metadiskurzivni rabi.

Najsplošnejšo definicijo povezovalcev podaja J. Moeschler:

»Pragmatični povezovalci so jezikovni zaznamovalci, ki pripadajo različnim slovničnim skupinam (priredni in podredni vezniki, prislovi, prislovne besedne zveze), in ki:

a) vežejo maksimalne jezikovne enote ali katere koli diskurzivne enote,

b) dajejo navodila o načinu povezave med temi enotami,

c) nas prisilijo, da iz diskurzivnih povezav izpeljemo sklepe, ki jih v odsotnosti povezovalcev ne bi mogli. $\ll^{23}$

Za našo analizo diskurza bosta pomembna dva sklepa, ki ju lahko oblikujemo na podlagi zgornjih definicij:

1. povezovalci so del nadpovedne skladnje;

2. za povezovalce je značilna večpomenskost: ista beseda lahko nastopa $\mathrm{v}$ vlogi povezovalca ali operatorja (primera (62) in (63) zgoraj), zato je pri analizi treba ločevati med semantično in pragmatično ravnino.

Predvsem povezovalci, torej vezniki v diskurzivni vlogi, lahko v skladu s teorijo argumentacije v jeziku delujejo kot zaznamovalci argumentacije. Glede na konvencionalnost argumentacije v jeziku so prav zaznamovalci tista dogovorjena sredstva, ki jih naslovnik interpretira kot govorčevo namero po argumentaciji.

\section{In med veznikom in konektorjem}

Veznik in je glede na rezultate $\mathrm{v}$ korpusu Fidaplus najpogosteje rabljeni slovenski veznik s $100.000^{24}$ pojavitvami v vseh besedilih in 56747 v korpusu govorjenih besedil, ki vključuje dramska besedila in transkripcije razprav iz Državnega zbora. To sploh ni presenetljivo glede na njegovo vlogo v vezalnem priredju, ki jo prenese tudi na vsa druga priredja. Taka raba je možna zaradi upoštevanja konteksta povedi in zaradi splošne vezalne narave in, ki jo izpričuje tudi v splošnih semantičnih raziskavah v drugih je-

\footnotetext{
${ }^{23}$ J. Moeschler, Les connecteurs pragmatiques, v: A. Reboul, J. Moeschler (ur.), Pragmatique du discours, Pariz 1998, 77.

${ }^{24}$ Frekventnost najpogostejših besed je omejena na 100000 pojavitev, zato bomo to številko še srečali tudi pri drugih pogostih veznikih - povezovalcih.
} 
zikih. Kontekst lahko razložimo tudi z Ducrotovim in Anscombrovim toposom, o čemer bo govora kasneje. ${ }^{25}$

\section{IN - ZAZNAMOVALEC VEZALNEGA RAZMERJA ALI KONJUNKCIJE}

Po Lyonsu ${ }^{26}$ (1972: 138-144) je konjunkcija, ki jo uvaja in, del propozicijskega računa, in je torej logični operator, ne veznik, kot ga pozna naravni jezik. Z imenom konjunkcija opiše celotno operacijo $p$ in $q$, ne le veznika/ operatorja, saj je konjunkcija $p$ in $q$ resnična le, če sta resnična tako $p$ kot $q$. Narava propozicij $p$ in $q$ ni posebej opredeljena, raba veznika/operatorja in zadošča za vzpostavljanje vezalnega odnosa.

V naravnih jezikih pa se raba in navadno pojavlja v povedih, kjer že obstaja neka bolj specifična povezava, npr. časovno sosledje (primer (68)), zaporedje po pomembnosti (primer (69)) ali vzročno-posledični odnos (pri$\operatorname{mer}(70))$ :

(68)

Poročila sta se in imela pet otrok.

(69)

Za petdeseti rojstni dan je dobil avto, Enciklopedijo Slovenije in kravato.

(70)

Spotaknil se je in si zlomil nogo.

Zgornje ugotovitve veljajo praktično za vse naravne jezike. V nadaljevanju pa bomo pogledali, kako se veznik in obnaša v slovenskem jeziku. Delovanje veznika in smo preučevali v slovenskem korpusu Fidaplus in ga primerjali z opisi v SSKJ.

Glede na opredelitev SSKJ je delovanje in opredeljeno na treh ravninah: na besednozvezni ravni med členi v stavku, na skladenjski ravnini v vezalnem in drugih priredjih in na ravnini izrekov.

Med členi v stavku je izpostavljenih 8 vrednosti, in sicer:

I. 1. za vezanje dveh istovrstnih členov - Oče in sin sta zdoma.

2. nav. ekspr., za vezanje dveh sorodnih pojmov v pomensko enoto Cast in slava $m u$.

3. nav. ekspr., pri ponavljanju iste besede za izražanje velike količine, visoke stopnje - Tisoči in tisoči slavijo zmago.

4. za seštevanje, prištevanje - Ena in tri je štiri.

${ }^{25}$ Glej poglavje Toposi, konektorji in argumentacijska gibanja.
${ }^{26}$ J. Lyons, Semantics, Cambridge 1977, 138-144. 
5. ekspr., navadno okrepljen za stopnjevanje - Ta bolezen se pojavlja na rastlinah in celo na živalih.

6. navadno v zvezi ta in ta - Pride ta in ta dan.

7. ekspr., z vejico ali pomišljajem, za izražanje nepričakovanega nasprotja-Mlad, in tako pokvarjen.

8. $\mathrm{z}$ vejico, v zvezi in sicer, in to za dopolnjevanje, pojasnjevanje prej povedanega - Njegov poklic zahteva znanje, in sicer resnično znanje.

Vidimo, da so štiri rabe označene kot »ekspresivne « in da se posebej izpostavlja zvezo ta in ta. V korpusu Fidaplus (www.fidaplus.net) na tem mestu izstopa vloga in kot veznika precej istorodnih sestavin, ki bi jih lahko označili za dvojnice in jih srečamo v navezavah Kolegice in kolegi, Primork in Primorcev, jasen in glasen, ni bil in ni (gl. spodaj, primer (71)), kriterijem in zahtevam, in podobno...

Gre za primere rabe retorične diskurzivne strategije poudarjanja z dvojnicami, ki jo zasledimo tudi v primeru (71), in sicer v okviru prve rabe in.

(71)

Samo mimogrede, ni bil in ni nepomemben podatek, da v sosednji Avstriji so bila pripravljena begunska taborišča za Slovence, ki bi prebežali ob napadu jugoslovanske vojske, vendar k sreči so bila ta taborišča prazna, kajti ljudje, rajši, kot da bi šli v ta taborišča in zapustili Slovenijo, so se javili v enote, da aktivno sodelujejo v obrambi ali pa v projektu osamosvajanja države Slovenije. (www.fidaplus.net: Seja državnega zbora 1999)

Poznamo še eno značilnost veznika in, ki bi jo našli kvečjemu v stilističnih knjigah in ne v slovničnih opisih, pa vendar je v vsakdanjem pogovornem jeziku pogosta, predvsem v besednih igrah: vezanje raznorodnih semantičnih sestavin, ki jih združimo z in, sproža komične učinke. Gre za uveljavljene kolokacije, ki se zaradi sinonimije združujejo v neobičajnih kontekstih, predvsem govorjenih, kot na primer (72), (73) in (74) spodaj, ki so postale že ljudski izreki. Takih primerov v korpusu nismo našli.

(72)

Prišel je z veseljem in s kovčkom.

(73)

Pridem všolo in sedem in osem.

(74)

Bil je b(B)led in Bohinj. 
In $\mathrm{v}$ vezalnem priredju pa ima po SSKJ naslednje vrednosti, označene z II:

1. za vezanje dveh stavkov, ki izražata sočasnost ali zaporednost - Otroci se tiščijo kpeči in se grejejo.

2. za vezanje dveh sorodnih povedkov - To pa grize in peče. čaka.

3. nav. ekspr., za izražanje intenzivnosti dejanja - On samo čaka in spet

4. za izražanje namena - Pojdi in zapri vrata.

5. za izražanje nasprotja s prej povedanim, pa-Samo tri dni je časa, in jaz sem čisto nepripravljen.

6. za izražanje vzročno-posledičnega razmerja, vzročno-sklepalnega razmerja, pogojno-posledičnega razmerja - Lani se je ponesrečila in še zdaj ne hodi.

7. čeprav, četudi - Trden ostani, in naj se svet podre.

Dejansko je vezalno priredje le tisto iz točke 1, vsa ostala pa so drugorodna: to je možno zaradi globinskega odnosa, toposa, na katerem temelji povezava med dvema deloma izreka. ${ }^{27}$ Kot je razvidno iz zgornjih točk 4, 5 , 6 in 7, veznik in izraža vsa možna medstavčna razmerja: vzročno-posledično, protivno in dopustno.

SSKJ opozori tudi na delovanje in na ravni izrekov, ki so med seboj ločeni z močnejšimi nekončnimi in končnimi ločili:

III. za piko ali podpičjem

1. z oslabljenim pomenom za izražanje pomenov kakor II, zlasti 4-7 Bodite mirni in nobenega šepetanja.

2. za navezovanje na prej povedano - Jaz sem končal. In $t i$ ?

3. za opozoritev na prehod k drugi misli - In še to. Ali ne pogrešate son$c a$ ?

4. za izražanje začudenja, presenečenja, nejevolje - In da se mi kaj takega ne ponovi već.

To so tipične medbesedilne oziroma diskurzivne funkcije in na tej ravni lahko trdimo, da in deluje kot povezovalec oziroma konektor. Resnično argumentacijske rabe so tiste, ki temeljijo na vzročnih, posledičnih in dopustnih odnosih. Oglejmo si nekaj takšnih primerov:

${ }^{27} \mathrm{O}$ toposih pišemo več v poglavju Toposi, konektorji in argumentacijska gibanja. 
(75)

Moje pripombe ne gredo v konkretne številke, pa tudi v posamezne podrobnosti odsekov, vendar tu, ker govorimo o nacionalnem programu, in ker je v samem uvodu zapisano, da gre za temeljne strateške interese države, bi začel pri nekaj vprašanjih, ki verjamem, da so mogoče že presežena, vendar se mi pa zdi, da bi bilo še vseeno čas, da bi o tem nekaj rekli.(www.fidaplus.net: Seja državnega zbora 1996)

(76)

Tudi jaz imam magnetogram in v njem piše, o čem sem govoril in zato mislim, da ni potrebno mojih besed kakorkoli sprevračati.

Se bom pa z vsem srcem zavzemal za to, da bo odbor pripravil rešitev, ki bo v globalu rešila vse te probleme in ta problem, ki ga je gospod Pukšič povedal, je samo en delček, in nima smisla, da se vlada z delčkom ukvarja, ampak naj se s celoto. Zato bom glasoval tokrat proti, čeprav sem za to, da se v to vlaga. (www.fidaplus.net: Seja državnega zbora 1999)

V primeru (75) je vzročni odnos še podkrepljen s ker, ki sledi in. V primeru 76) pa je posledični drugi in, ki ga dopolnjuje zato. O tretjem in iz tega primera (in ta problem) bi lahko sklepali, da je dopustno-protivni, medtem ko je četrti (in nima smisla) spet posledični.

$(77)$

Kot Mariborčan, in ne edini, opažam, da te investicije stojijo tik pred dokončanjem, kar je normalna reakcija tega podjetja, ker če bi dokončali investicije, bi se po vsej verjetnosti ta del prelival z drugim delom, ker ne bi bili olastninjeni, denar drugam, in s tem nastaja velika gospodarska škoda v Mariboru. (www.fidaplus.net: Seja državnega zbora 1999)

(78)

Toda avtocestnega sistema niso začeli graditi spomladi 1995, ampak v bistvu na jesen 1993 oziroma spomladi 1994. In že takrat je ta smer začela zaostajati. (www.fidaplus.net: Seja državnega zbora 1996)

V primeru (77) je drugi in nadomestljiv spa ali ampak in označuje protivno razmerje, podobno je s primerom (78). Naslovnik ta in prepozna in interpretira kot protivnega na podlagi nasprotujočih si vsebin.

Če povzamemo ključne značilnosti veznika in, lahko sklenemo, da je po svoji naravi to veznik za izražanje dodajanja, naštevanja, vendar lahko prevzame še druge vloge kot vzročno-posledični oziroma protivni povezovalec. $V$ tem primeru lahko govorimo o argumentaciji podobno kot pri danih vrstah povezovalcev. 


\section{In kot povezovalec oziroma zaznamovalec zgradbe diskurza}

Kot konektor oziroma povezovalec, ki deluje na ravni diskurza, je in velikokrat uporabljen kot zaznamovalec zgradbe diskurza. ${ }^{28} \mathrm{~V}$ zapisanih govorjenih besedilih je v tej vlogi običajno označen z veliko začetnico, torej tudi intonančno ločen od prejšnjega diskurza. Takih pojavitev je bilo v korpusu 3834. Hierarhizacija za zaznamovanje zgradbe diskurza po zaporedju ali pomembnosti se pojavlja lahko eksplicitno, z besednimi zvezami, ki vključujejo bodisi naštevalno, bodisi časovno členjenje: in drugič, in zadnje, in tretje (primer (79)):

(79)

V prvi vrstici drugega odstavka se, prvič, črta beseda $»$ se «. In drugič, za besedo »odstavka« se vstavi »Ministrstvo za kmetijstvo in gozdarstvo «. Tretjič, v besedi » predpišejo « se črta zadnji zlog tako, da se glasi beseda brez zloga »predpiše«. Tako spremenjena prva vrstica drugega odstavka se potem glasi: »Izjemoma lahko iz razlogov iz prejšnjega odstavka Ministrstvo za kmetijstvo in gozdarstvo predpiše ...«. (DZ 1993)

Rabe in sedaj (primer (80)), in zdaj (primer (81)), in potem, in takrat (primer (82)) zaznamujejo rabo povezovalca in $\mathrm{v}$ zvezi s časovnimi in krajevnimi prislovi, ki je prav tako zelo pogosta.

(80)

In sedaj bom natančno razložil zakaj. (www.fidaplus.net, Državni zbor 1993) (81)

Osebno menim, da tisti, ki mislijo, da se danes naj ne sprejme nič, dovolijo nadaljnje nejasno delo v tej komisiji in škodijo nekaterim principom, ki bi učinkovitosti dela komisije pomagali. In zdaj bom jaz demagog, tako kot je bilo že mnogo drugih v tem, tisti želijo zavlačevati normalno delo te komisije. Zato predlagam, da o tem glasujemo. Če bomo izglasovali drugače, bomo izglasovali drugače, to je pač večina, ki v Državnem zboru odloča. (www.fidaplus.net, Državni zbor 1993)

Lep pozdrav vsem! Mislim, da je gospa Pozsončeva v svojem poročilu stvari malo omilila. Razprava na Komisiji za narodnosti je bila zelo ostra prav na tej točki, kako so narodne skupnosti v statutu zastopane. Predvsem je bilo govora o njihovi avtonomiji in pristojnostih, ki jih imajo. In takrat smo sklenili, da

${ }^{28}$ Zaznamovalec zgradbe diskurza ali marqueur discursif po francosko oziroma discourse marker po angleško. 
Komisija za narodnosti predlaga Državnemu zboru, da ne da soglasja k statutu, dokler Svet RTV Slovenija ne bo obravnaval in upošteval navedenih pripomb komisije. (www.fidaplus.net, Državni zbor 1993)

In se v kombinaciji in potem $\mathrm{v}$ govorjenem diskurzu pojavi 69-krat, a samo dvakrat v kombinaciji in nato (primera (83) in (84) spodaj). Časovno zaporedje, ki ga in lahko implicitno izraža sam (npr. primer (68) zgoraj), je tu eksplicirano.

(83)

Spoštovane poslanke in poslanci! Sicer se mi zdi že malo porabljanje energije, ko hodimo sem gor, ampak vseeno se mi zdi, da je na nekatere stvari potrebno opozoriti in jih je posebno Komisija za žensko politiko opozorila. Gre za cel sklop, ker tukaj se začne in tukaj se mi zdi pomembno to opozoriti, sklop varovanja osebnih podatkov. Namreč predlagatelj je relativno zaščitil vprašanje in uporabo osebnih podatkov, po naši oceni pa gre še za preširoko zajemanje podatkov, predvsem v tistem 41. členu, ko govorimo, da je potrebno podati tudi rojstne podatke staršev in po naši oceni ti podatki niso potrebni. In potem preširoko tolmačenje tako imenovanega celotnega področja tistih otrok, kateri so potrebni pomoči. Za te otroke se zajema kar spekter nekaterih oziroma kar cel seznam podatkov, predvsem tako imenovane družinske anamneze in se nam zdi, da bi bilo potrebno v zakonu zavarovati, kdo odloči, kdo je potreben takšne pomoči in seveda potem tudi, kdo izvaja zbiranje teh podatkov in seveda tudi varovanje teh podatkov. (www.fidaplus.net, Državni zbor 1995)

(84)

Prehajamo h glasovanju o predlogih stališč in sklepov. V pregledu imate predlog stališč in sklepov oziroma dodatnih stališč. Najprej bomo seveda glasovali o dodatnih stališčih in sklepih, s tem da bo na začetku vrstni red glasovanja tak, da bomo najprej glasovali o predlogu stališča pod točko 1, ki ga imate v pregledu, potem bomo glasovali o predlogu stališča, ki ga imate v pregledu od točko 2 in nato pridejo na vrsto dodatno vloženi amandma k predlogu sklepa Odbora za notranjo politiko in pravosodje, ki ga je podpisalo šest poslancev, in pred tem seveda amandma na ta amandma, ki ga je vložila poslanska skupina Združene liste. In nato, če seveda vse to ne bi bilo sprejeto, po spisku predlogov novih stališč in sklepov, dalje. (www.fidaplus.net, Državni zbor 1996)

In zaradi svoje vezalne vloge zaznamuje tudi komplementarnost heterogenih elementov bodisi na ravni dejstev, bodisi na ravni tipov operacije, kar je tipično za govorjeni diskurz. Tudi kadar ni posebej povezan z zgo- 
raj omenjenimi prislovi, ki hierarhizirajo diskurz bodisi po pomembnosti, bodisi po časovnem zaporedju, povezovalec in zaznamuje prehod od enega dejanja k drugemu oziroma povezavo med dogodki, med katerimi ni druge logične povezave. Ne gre niti za časovno sosledje; v povezavi z in dejanja in dogodki postanejo komplementarni v zavesti naslovnika. V spodnjem primeru (primer (85)) vidimo, da vsak in z veliko začetnico uvaja razširitev prejšnje teme.

\section{(85)}

In vi ste, kot predsednik zbora, odigrali to vlogo, da ste ga zaščitili, da niste dovolili replik, da niste dovolili, da bi predvsem poslanci in poslanke opozicije pojasnili svoja stališča do odstopa ministra, če ste že postopek tako izpeljali, da ste dali ministru prej možnost, da je odstopil, kot pa bi do konca lahko mi pojasnili svoja stališča. In tudi ugovor, da, saj ministra več ni s tem, ko odstopi - še vedno je, dokler ni izvoljen novi, saj mora opravljati tekoče posle v svojem ministrstvu! In zato bi bilo prav, da bi slišal do konca, kaj smo menili o njegovem delu. Namreč, to ni tako nepomembno. Večkrat slišimo, tudi ob sedanjih zadnjih odstopih, da so ministri (to sicer iz nepreverjenih krogov, tako da moram to poudariti), da so nekateri ministri marsikdaj v svojih zadnjih dnevih opravili ogromno dela, predvsem finančnega, seveda. (www.fidaplus.net, Državni zbor 1996)

Če gre v zgornjem primeru raba in z roko v roki z logičnim napredovanjem diskurza, pa v primeru (86) spodaj, kjer je koherenca in razumljivost na meji, vidimo željo po tem, da govorec vzpostavi koherenco z veznikom in, čeprav je samo sosledje nekoherentno.

Drugače pa, glede zavajanja javnosti, veste, samo naslednje: ne bi se oglašali, če ne bi neposredno po protestu upokojencev, pa ni protest važen, ampak po sprejemu naše odločitve, bila koncentrirana - jaz trdim dogovorjena s strani Vlade - prisotnost v javnosti, ki so hoteli izničiti vsak pomislek, ki je bil izre-

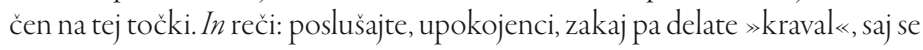
nič ne bo zgodilo. Zakaj govoriti, da se nič ne bo zgodilo, če smo pa tukaj diskutirali o tem, da se bo zgodilo?! In eni mislijo, da je prav, da se zgodi, eni pa da ne. In je bil ves čas govor, pokojnine ne bodo manjše. Poslušajte, govoriti, da pokojnine ne bodo manjše, če smo se mi odločali, tista večina, ki se je odločila, da jih je treba zmanjšati, da bomo prihranili 7 milijard, potem je to zavajanje javnosti! Zakaj je bilo to treba početi?! To je tisto, kar želimo povedati. Naj potem tisti, ki so večinsko to odločitev sprejeli, korajžno povedo: ja, 
vedeli smo, da moramo iz proračunskih razlogov prihraniti 7 milijard in zato smo jih prihranili s tem, da bodo pokojnine manjše. In to je vse, kar želimo povedati. Vse drugo so pa take polresnice, ki pač bi rade tolažile ljudi, ampak ne bomo jih potolažili, ker pokojninski izpiski bodo prišli - to je vse! Hvala. (www.fidaplus.net, Državni zbor 1994)

Tudi in na začetku vprašalnih povedi spada v podtip povezovalcev, ki zagotavljajo diskurzivno koherenco. $\mathrm{Na}$ začetku vprašanj s povezovalcem in zaznamuje ponovno omenjanje poprejšnjega konsenza glede teme: $\mathrm{v}$ tem primeru ima anaforično, pa tudi tematizirajočo vrednost, saj se nanaša na prej omenjeno temo. Vprašanje, ki ga uvaja in, se navadno nanaša na nek komplementaren vidik teme ali na novo temo, ki je komplementarna s predhodno. To je razvidno tudi iz primera (87) spodaj: vprašanje in kaj se nanaša na prejšnji izrek danes oz. nocoj labko nekaj stori on sam in je s tem primerno poudarjeno.

(87)

Danes oz. nocoj pa lahko nekaj stori samo on sam. In kaj? To, da umakne predlog za zamenjavo in omogoči, da bo tako Državni zbor kot vsa njegova delovna telesa umirjeno in argumentirano razpravljal o vseh ozadjih tega težkega zapleta. Samo na ta način lahko predsednik Vlade računa, da bo ostal verodostojen tudi pri vseh tistih, ki se sicer z njim ne strinjamo. Hvala lepa. (www.fidaplus.net, Državni zbor 1996)

\section{IN V KOMBINACIJAH Z DRUGIMI PRISLOVI ALI VEZNIKI}

In nastopa tudi v kombinacijah z gotovostnimi zaznamovalci in seveda, in gotovo, in dejansko, ki dodajajo govorčevo jamstvo za sklepanje, ki ga uveljavlja (primeri (88), (89) in (90)):

Vsi vemo, da so po vojni bila izdelana poročila in pa analize o teh dogodkih za osamosvojitev, ki se nanašajo na ta mejni prehod in pa seveda tudi na druge. (www.fidaplus.net, Državni zbor 1999)

Kar zadeva druge izjave, bi omenil samo še mogoče izjavo, bivšega svetovalca za nacionalno varnost ameriškega predsednika, Breanta Scowcroffta, ki je napovedal, da se bo Nato razširil samo z višjegrajsko skupino. Skratka v teh načrtih, ki so danes v delu na zahodu, Slovenije nekako ni zraven. In gotovo je poleg objektivnih težav, o katerih pač večkrat slišimo, je tudi verjetno nekaj subjektivnih težav, oz. so nekatere težave, ki jih produciramo sami, ki na- 
nje nismo dovolj pozorni. Zaradi tega ponavljam, mislim, da že ne vem katerič, pobudo, da nam Slovensko zunanje ministrstvo dostavi zunanjepolitično strategijo. (www.fidaplus.net, Državni zbor 1994)

(90)

Če je za sanacijo, za katero minister da roko v ogenj, in da bo ta zadeva ozdravila, O.K., ampak samo to, da je jasno. In meni je to jasno bilo prvič in jasno drugič, tako kot je napisano; ne tisto, kar sem jaz morda v klopi mislil. In zato je to na nek način sprenevedanje Vlade, ki hoče nekaj sedaj podtakniti, kakor da smo mi nekaj narobe mislili, nekaj ne vem kaj. In dejansko je to res to, kar so nekateri že povedali, da Vlada sedaj hoče nekaj prenesti na naša ramena, hoče tisto svojo napako, ki jo je ona naredila, jo hoče zdaj prenesti pač na Državni zbor. (www.fidaplus.net, Državni zbor 1995)

In, ki uveljavlja vrednotenje, srečamo predvsem $\mathrm{v}$ povezavi s prislovi in glagoli mišljenja, ki modalizirajo, kar sledi. V korpusu Fidaplus smo zasledili primere $\mathrm{z}$ in verjetno, in problematično, in skoda, in menim, in je nujno, in prav je, in v resnici, in res je, in zanimivo. Na ta način se izraža bodisi komentar povedanega (primer (91)) spodaj) ali komentar izrekanja (primer (92)) (in jaz mislim, in zato mislim, in zahtevam, in moram povedati, in zato prosim / bi prosil).

(91)

In mislim, da volivci imajo pravico to vedeti, da je prav, da to vedo volivci. Ker s tem na nek način odločajo o prihodnosti oblasti in o prihodnosti države. (www.fidaplus.net, Državni zbor 1996)

In zanimivo, minister je rekel: »Rekonstrukcija, kot je bila opravljena tokrat.« Gospod minister, koliko rekonstrukcij je že bilo, ali bo še katera, kaj se še išče s temi rekonstrukcijami, namreč vi ste rekli: »... tako kot je bila opravljena tokrat.«Zanimajo me razlike v rekonstrukcijah, kaj je prinesla prva, druga ali kolikor jih je bilo. (www.fidaplus.net, Državni zbor 1994)

$\mathrm{V}$ povezavi z drugimi konektorji se in $\mathrm{v}$ korpusu Fidaplus najpogosteje pojavlja v kombinaciji s posledičnim povezovalcem zato, pojasnjevalnim členkom sicer in protivnim členkom vendar.

Varianta in sicer prinaša pojasnjevanje, natančnejšo opredelitev že povedanega. Kombinacija pojasnjevalnega in sicer vsebuje 12616 primerov v celotnem korpusu, v govorjenih besedilih pa 89 . Za ilustracijo podajamo primera (93) in (94) spodaj, kjer gre prvič za navezovanje na celotno vsebino, drugič pa na iztočnico obe vprašanji: 
(93)

Že več let ni bilo sprejeto nobeno poročilo tožilstva. Še več! Nekatera so bila celo zavrnjena. Personalno politiko v tožilstvu vodi, tako kot si jo je nekoč z neko izjavo na tožilski zabavi začrtal, sam. In sicer poenostavljeno se glasi naslednje: »Kdor je z nami, bo za to nagrajen.« Tako je vsakič, ko je bilo to potrebno, ignoriral odločitve personalne komisije ali pa je kar med razpisi samimi menjal pravila za njeno odločanje. (www.fidaplus.net, Državni zbor 1998) (94)

Sedaj pa bi šel na obe vprašanji. In sicer, v dnevnem tisku smo prebrali, da je gospod Peterle v razgovoru z Italijanskimi partnerji, v znak dobre volje je bil pripravljen Italijanom dati del Slovenskega premoženja, kar je tako rekoč začudilo tudi Belgijskega zunanjega ministra in tudi sprožilo neke določene reakcije. In v zvezi s tem, bi se navezal tudi na sedanjo zaporo ob oddaji obeh patruljnih čolnov Slovenske policije, naši državi. Me zanima, kaj je Ministrstvo za zunanje zadeve storilo na tem področju? Konec koncev je to delo Zunanjega ministrstva, da ureja te mednarodne odnose in pa še eno kratko vprašanje gospodu Kunstlju. Prej ste omenili, da so bile v strankah opravljene diskusije, v zvezi z zunanjepolitično strategijo. Kot jaz vem, v naši stranki ni bilo opravljene nobene takšen diskusije. In bi prosil tudi na to, če mi odgovorite. Hvala. (www.fidaplus.net, Državni zbor 1994)

In zato uvaja posledično oziroma pojasnjevalno razmerje, takih pojavitev je bilo v govorjenih besedilih 458. Navajamo primer (95):

Se pravi, situacija, ko imamo trikrat možnost, da nekdo preneha ministrsko funkcijo, vsakič pomeni, da ko jo preneha, ni možno sprožiti naslednjega postopka. V tem je vsa logika tega, te moje odločitve. In zato je bila razprava o razrešitvi brezpredmetna v tistem trenutku, ko je minister Tajnikar odstopil. Ni bilo koga več razrešiti, minister je pač odstopil. In velja še to povedati, da ima minister v vsakem trenutku pravico odstopiti, celo pri točki, ki se ne nanaša na njegovo odgovornost; lahko zagovarja nek zakon in lahko v tistem trenutku pač ponudi - ne ponudi, odstopi - in ko se zbor seznani s tem odstopom, njemu funkcija ministra preneha. (www.fidaplus.net, Državni zbor 1996)

In vendar uvaja protivno razmerje med dvema nasprotujočima si argumentoma, od katerih je drugi močnejši za sklep, kar je razvidno tudi v spodnjem primeru (96): 


\section{(96)}

Saj je prav smešno. Ta dva tabora v bistvu, tabor, ki je nastal, bi rekel, proti Janši. Janša v bistvu nima stvari razčiščenih popolnoma. In vendar vas izziva, in ste vi v strahu pred njim, bi rekel, si ne upate narediti ene načelne in točne poteze. Pa ne načelne poteze, ki bi bila napačna. Ne! Točne, napačne poteze s pravilno proceduro. (www.fidaplus.net, Državni zbor 1996)

$\mathrm{O}$ vrednostih veznika in povezovalca in lahko torej sklenemo naslednje: je najpogostejši veznik, ki deluje na ravni besedne zveze, predikacije in propozicije, na ravni povezovanja izrekov pa dobi vlogo povezovalca. Njegova argumentacijska vloga ni primarna, v argumentacijske odnose vstopa predvsem, ko povezuje dele izreka, ki so med seboj v vzročnem, posledičnem ali protivnem razmerju, kar je tudi ena od možnosti, danih v SSKJ, ali pa, kadar se in $\mathrm{v}$ povezavi s pojasnjevalnimi, posledičnimi in protivnimi povezovalci vključuje $\mathrm{v}$ argumentacijska diskurzivna gibanja. Ta možnost, ki jo ima na ravni izrekov, mu je dana predvsem sekundarno s povezovalci, ki sledijo, oziroma razmerjem med toposi, v katerem nastopa.

Zanimivo je, da se problem argumentacije s povezovalcem in $\mathrm{v}$ Ducrotovih delih in delih Ženevske šole ne omenja, razen v zvezi z in veznikom, ki ne more povezovati sklepa in argumenta, ${ }^{29}$ ker obstaja splošno pravilo, po katerem mora in povezovati elemente iste narave. Kot smo že večkrat skušali prikazati v pričujoči razpravi, ta trditev velja za in - veznik, za in povezovalec pa ne, saj ima drugačno funkcijo.

$\mathrm{Za}$ argumentacijsko vrednost, ki jo izraža govorec, je pomembna še funkcija vrednotenja, ki jo prinaša in kot povezovalec v kombinaciji z glagoli (in mislim, in verjamem) oziroma gotovostnimi prislovi (in seveda, in dejansko, in gotovo) Argumentacijska vrednost tudi tu izvira od drugod, in sicer iz govorčeve garancije za resničnost. Govorec jamči za ustrezno interpretacijo (in menim, in trdim), s čimer se uresniči ena od zahtev argumentacije, ki jo predvideva Toulminov model. ${ }^{30}$

Pomembna vloga je tudi strukturacija diskurza v povezavi s prislovi (in potem, in prvič, in drugič) ali brez njih. V slednjem primeru in skuša vzpostaviti koherenco. Govorci se ga poslužujejo, kadar želijo naknadno uvesti koherenco v sicer nekoherenten ali močno raznoroden diskurz. V teh rabah se pojavlja predvsem na začetku izrekov in vzpostavlja anaforično navezavo na prej izrečeno.

\footnotetext{
${ }^{29}$ O. Ducrot et al., Les mots du discours, Paris 1980, 201.

${ }^{30} \mathrm{~S}$. Toulmin, The Uses of Argument, Cambridge 1958/1995. O Toulminu in njegovem modelu argumentacije podrobno piše Igor Ž. Žagar v poglavju Topoi: črna skrinjica argumentacije.
} 
In se v diskurzu torej uresničuje v svojih mnogih vlogah - kot veznik istorodnih sestavin, kar še vedno ostaja njegova najpogostejša raba, in kot povezovalec. Slednjega glede na kontekst navezav in prislove oziroma glagolske oblike, ki sledijo, uvrščamo med argumentacijskim povezovalcem in zaznamovalcem strukturacije diskurza. 


\section{Toposi, konektorji in argumentacijska gibanja}

$\gg$ Il a été né dans la famille du préfet de la police, mais c'était une famille lettré où l'on aimait l'art et la littérature. ${ }^{1}$

\section{Topos}

gornji stavek je na nekem znanstvenem srečanju v Parizu predavatelj izgovoril v povezavi z življenjepisom nekega pakistanskega režiserja. Takoj se zamislimo nad povezavo, ki jo je s tem ustvaril - policist, vendar izobražen. Kar pomeni, da sta prva in druga trditev za avtorja v nasprotju. Policist ne more biti izobražen, oziroma če je izobražen, je to v nasprotju s pričakovanji - vsaj v francoski družbi. Mehanizem, ki omogoča tako sklepanje in argumentacijo, sta Ducrot in Anscombre poimenovala topos.

Historično ozadje tega koncepta velja za enega najbolj problematičnih, saj je že v antiki obstajala množica interpretacij o tem, kaj topos je in kakšna je njegova vloga zlasti v okviru retorike. Kot nakazuje Igor Ž. Žagar v prvem delu te knjige, bi v najširšem smislu lahko govorili o dveh tradicijah, sofistični, ki topos (v stari grščini izraz pomeni 'mesto' oziroma 'kraj') pojmuje kot »skladovnico《že pripravljenih argumentov (najrazličnejših oblik in vsebin), ter aristotelski, po kateri je topos argumentativna shema, ki dialektiku ali retoriku omogoča konstrukcijo argumenta za dani sklep. A dejstvo je, da se obe pojmovanji v antiki med sabo prepletata, da jih celo pri Aristotelu ne najdemo v obliki jasne razmejitve in da tudi kasnejši antični teoretiki niso natanko vedeli, kako nedvoumno opredeliti topos in

\footnotetext{
${ }^{1}$ Prevod: »Rojen je bil v družini načelnika policije, vendar je bila to izobražena družina, kjer so imeli radi umetnost in literature.«
} 
njegove funkcije. Posledično so zelo raznolike tudi sodobne interpretacije, ki koncept toposa vključujejo v svoje teoretske modele. ${ }^{2}$

V teoriji argumentacije v jeziku sta Ducrot in Anscombre ${ }^{3}$ topose premaknila od klasične in logične tradicije, izhajajoč pri tem iz teze, da »argumentacijski odnosi niso dodani semantični vrednosti izreka«, ampak so »temeljni, prisotni od najgloblje ravni analize dalje «. ${ }^{4}$ Toposi so pri njiju sicer etimološko vezani na Aristotela, vendar avtorjema ne gre za opisovanje logično-psiholoških mehanizmov argumentacije, ampak za opisovanje argumentacijskih diskurzov, in sicer predvsem navezav dveh segmentov, $A$ (argumenta) in $C$ (sklepa). Ta navezovanja v argumentaciji uporabijo še tretji člen, garant, ki omogoča prehod od $A$ do $C$. In prav ta garant argumentacijskih navezav je topos. ${ }^{5}$

Po Anscombru ${ }^{6}$ med izrekanjem govorec daje navodila o poti, ${ }^{7} \mathrm{ki}$ jo je izbral, in naslovnik poskuša to pot rekonstruirati na podlagi danih kazalcev. Ti kazalci, ki omogočajo izbiro med izbranimi potmi, so toposi. Predstavljajo splošne principe, ki služijo kot podlaga za sklepanje, niso pa sklepanje samo. Nikdar niso zatrjeni na ta način, da bi se govorec predstavljal kot njihov avtor, tudi če to dejansko je. Vedno so predstavljeni kot predmet soglasja v določeni skupnosti, ki je lahko širša ali ožja, oziroma celo skrčena na posameznika, t. j. govorca.

Topos torej določa premise, ki jih je v določeni situaciji relevantno uporabiti, in je garant za prehod od premis k sklepu. Vrednost »garanta《 izvira iz njegove proceduralne rabe. Zato ga lahko po eni strani predstavimo kot zakon, po drugi pa kot samoumevno resnico.

O značilnostih toposa izčrpno piše že Igor Ž. Žagar v prvem delu knjige, kjer zelo jasno opredeli tudi razlike med logiko in argumentacijo v vsakdanjem jeziku, med sestavinami logičnega in retoričnega sklepanja in vlogo, ki jo topos opravlja v slednjem. ${ }^{8} \mathrm{Da}$ se ne bi preveč in po nepotrebnem ponavljali, na tem mestu povzemimo le nekaj ključnih značilnosti, ki ve-

\footnotetext{
${ }^{2}$ Topos in njegove konceptualizacije podrobno obravnava Igor Ž. Žagar v poglavju Topoi: crrna skrinjica argumentacije.

${ }^{3}$ J.-C. Anscombre, O. Ducrot, L'Argumentation dans la langue, Bruselj 1983; J.-C. Anscombre et al., Théorie des topoï, Pariz 1995.

${ }^{4}$ J.-C. Anscombre et al., n. d., 15.

${ }^{5}$ O. Ducrot, Topoï et formes topiques,v: J.-C. Anscombre et al. (ur.), Théorie des topoü, Pariz $1995,85$.

${ }^{6}$ J.-C. Anscombre et al., n. d., 38-39.

${ }^{7}$ Fr. parcours.

${ }^{8}$ Glej zlasti poglavji Argumentacija v jeziku proti argumentaciji z jezikom in Topoi: črna skrinjica argumentacije.
} 
ljajo za topos, kot ga pojmuje Ducrotova teorija argumentacije v jeziku, in jih pokažimo na izbranih primerih:

- topos je skupen določeni družbi (ki je lahko sestavljena tudi le iz govorca in naslovnika). Ta si mora biti gotova o njegovem upoštevanju že pred začetkom diskurza.?

- topos je splošen, kar pomeni, da velja za številne splošne in posebne situacije;

- topos je stopnjevit, kar pomeni, da vzpostavi odnos med dvema argumentacijskima lestvicama. (97):

Kaj pomeni, da je topos splošen, bomo skušali prikazati s primerom

Ta avto je poceni. Torej ga je treba kupiti.

Argumentacija v zgornjem primeru je legitimna, če združi lastnost poceni in kupiti, vsaj v naši potrošniški družbi. To ne pomeni, da je argumentacija podvržena normam zdrave pameti. Takšno argumentacijo je mogoče tudi zavrniti in postaviti nove odnose, ki niso podrejeni doksi.

Bistvo stopnjevitega značaj toposa se pokaže, ko se vzpostavi odnos med stopnjevitima predikatoma, dvema argumentacijskima lestvicama (primer (98)), ki sta tudi stopnjeviti. ${ }^{10}$ Topos dobi obliko bolj $/$ manj $O=P$, bolj / manj $O^{`}=P^{\prime}$.

(98)

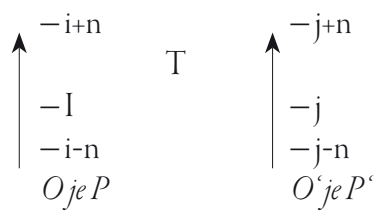

$I$ in $j$ zaznamujeta stopnjo $P$-josti od $O$ in $P^{\prime}$-josti od $O^{\prime}$. Argumentacija je možna zaradi dejstva, da topos v globinski strukturi vzpostavi povezavo med dvema argumentacijskima lestvicama. To lahko prikažemo z argumentacijskima lestvicama kot v primeru (99):

\footnotetext{
${ }^{9}$ Topos je podlaga diskurza in ima kot tak veliko skupnega s presupozicijo.

${ }^{10} \mathrm{O}$. Ducrot, Le dire et le dit, Paris 1984; J. Moeschler, Argumentation et conversation. Éléments pour une analyse pragmatique du discours, Paris 1985, 68.
} 
(99)

$$
\uparrow+\text { poceni } \uparrow+\text { kupiti }
$$

Bolj je neka stvar poceni, bolj jo je treba kupiti.

Podobno lahko ponazorimo tudi primer (100), ki je vzet iz govorjenega diskurza francoske oddaje Polémiques (1994):

JS1: Et /.../ de quoi parlons-nous? \ On parle de plus de 50000 entreprises de production, on parle de 20 milliards de chiffres d'affaires au niveau de la production /et on parle de 35 légumes. Alors, aujourd'hui, aujourd'hui, depuis que nous posons les questions au ministre le 25 juillet, le 25 novembre, le 6 avril / et puis des séries de rencontres, on nous répond au niveau du Ministère, tout à coup / on nous répond "choux-fleurs: Bretagne" $\downarrow$ Je rappelle: il y a 35 légumes, il y a une trentaine de départements concernés.

JS1: In ... o čem govorimo? Govorimo o več kot 50000 proizvodnih podjetjih, govorimo o 20 milijardah bruto proizvoda na ravni pridelave in o 35 vrstah zelenjave. No, danes, danes, odkar postavljamo vprašanja ministru 25. julija, 25. novembra, 6. aprila in potem v seriji srečanj, nam na ravni ministrstva odgovarjajo "cvetača - Bretanja”. Še enkrat poudarjam: gre za 35 vrst zelenjave in kakih trideset departmajev.

Govorec v zgornjem primeru izpostavi topos T1: več ko neka stvar povzroča težav, bolj se je treba o njej pogovarjati. Topos je stopnjevit na naslednji način: veliko se govori o cvetači v Bretanji. Gre pa za 35 vrst zelenjave in okrog trideset departmajev, zato je treba najti kompleksnejšo rešitev. Shematično topos iz primera (100) predstavimo takole:

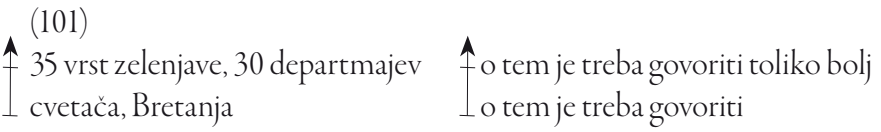

Kot je že bilo omenjeno in kot je razvidno iz zgornjega primera, toposi niso zatrjeni. So del globinske pomenske paradigme in tako implicitni. Glede na funkcijsko slovnico ${ }^{11}$ jih lahko umestimo na raven predikacije, kjer se kodira dejansko stanje. Predstavljajo izpeljavno povezavo ${ }^{12}$ med dogodki oziroma lastnostmi, s katerimi so argumenti povezani s sklepom in

\footnotetext{
${ }^{11}$ S. C. Dik, The Theory of Functional Grammar. Part I: The structure of the clause, Dordrecht 1989.

${ }^{12}$ Fr. connexion inférentielle.
} 
temeljijo na skupnih predpostavkah in pojmovanju sveta. ${ }^{13}$ Govorec s pomočjo toposov vzpostavi povezavo med dejanskim stanjem in svetom, ki ga obkroža. Dejansko stanje je osnovano na dejstvih, vrednotah, normah, splošnih ali posebnih predpostavkah.

Temeljni koncept predstavljene teorije je ta, da med izreki obstaja argumentacijski odnos. Ta odnos je binaren: en izrek je argument za nek drugi izrek, ki je njegov sklep. Sklep je lahko dejansko izražen, lahko pa je potencialen, možen, predstavljen zgolj kot argumentacijska namera izreka.

Po J. C. Anscombru' ${ }^{14}$ je jezikovno dejstvo, da toposi obstajajo; to je osnovna hipoteza teorije argumentacije v jeziku. Sociološko dejstvo je, da $\mathrm{v}$ določenem obdobju na določenem mestu obstaja določen topos. Toposov ne srečamo le na ravni navezav, ampak tudi na leksikalni ravni, kjer so temelj pomenu besed. Hkrati pa tvorijo možnost za izražanje stereotipov, družbenih predpostavk in predsodkov, ki jih govorci hote ali nehote izrazijo z rabo povezovalcev.

Od rabe toposa v zvezi s povezovalci je odvisno, ali se bo nek odnos v jeziku pokazal kot vzročno-posledični ali protivni. Če povežemo primer toposa, ki je pogosto omenjen pri Ducrotu in sodelavcih, ki delujejo v okviru njegove teorije, ${ }^{15}$ namreč deževati in iti ven, je zanj tipično, da ga obravnavamo kot protivni odnos, če ga povežemo z našim civilizacijskim okvirom. Tako tvorimo izreke kot (102) a) in b):

\section{(102)}

a) Dežuje, zato ne gremo na izlet.

b) Dežuje, ampak bomo vseeno šli ven.

Če pa se postavimo v svet polžev, ${ }^{16}$ velja tam obratno, vzročno-posledično razmerje, saj vemo, da mokrota polžem omogoča hitrejše gibanje. Zato so v svetu polžev možni le primeri navezav kot (103) a) in b) spodaj:

(103)

a) Dežuje, pojdimo naprej, odprimo hišice ...

b) Pripeka, pa bom vseeno zlezel do naslednjega lista...

\footnotetext{
${ }^{13}$ A. Ellerup Nielsen, The Argumentative Impact of Causal Relations - An Exemplary Analysis of the Free Predicate in the Promotional Discourse, Argumentation 10 (1996), 330.

${ }^{14}$ J.-C. Anscombre et al., Théorie des topoï, Pariz 1995, 39.

${ }^{15}$ Prim.: E. Roulet et al., L'Articulation du discours en français contemporain,Bern 1985; J. Moeschler, Argumentation et conversation. Éléments pour une analyse pragmatique du discours, $\mathrm{Pa}$ ris 1985.

${ }^{16}$ Kot za primer navaja M. A. Morel, La concession, Paris 1996, 7.
} 
$\mathrm{Na}$ osnovi slovenskih primerov bomo v nadaljevanju prikazali, kako medsebojno delujejo toposi in konektorji.

\section{Odnos med toposi in konektorji}

$\mathrm{Na}$ eni strani nanašalni izrazi prinašajo s seboj celo mrežo toposov, ki izvirajo iz polja toposov, na drugi strani pa obstajajo določeni leksemi (npr. argumentacijski operatorji), ki usmerjajo ali vodijo izbiro v pahljači tako izbranih toposov. V diskurzu se toposi navezujejo še s pomočjo povezovalcev, kar dodatno zmanjšuje lestvico možnih toposov. Tako je treba sklepati, da že sam pomen izreka vsebuje kazalce za izbiro toposov.

Toposi v diskurzu se povezujejo z operatorji in konektorji. Lastnost operatorja je, kot smo videli v prejšnjih poglavjih, da argumentacijsko usmeri izrek (primera (104) in (105)):

(104)

Šele osem je (usmerjenost k zgodaj).

(105)

Skoraj/že osem je (usmerjenost k pozno).

Ta usmerjenost omogoča, da uporabimo izrek v argumentacijskem dejanju in da hkrati uporabimo topos. V primeru (104) Šele osem je bomo uporabili topos Več je časa, manj se mudi. V primeru (105) Skoraj/že osem je bomo uporabili topos Manj je časa, bolj se mudi. Dejstvo, da postavimo informacijo osem je na lestvico zgodaj ali pozno, določa njen odnos z drugo lestvico, ki predstavlja drugi del toposa, v tem primeru muditi se. Sklep argumentacijskega dejanja je avtomatično dan s toposom. Sklep odgovarja vsebini, združljivi z drugo propozicijo toposa. ${ }^{17}$

Globinsko se topos nahaja v vsaki argumentacijski zvezi izrekov, ki jih vežejo povezovalci. Glede na to, ali je povezovalec dvo- ali trimestni predikat, se določa število toposov, ki se nahajajo v globini izreka. Pri vzročnem in posledičnem odnosu, kjer je povezovalec dvomestni predikat, se s toposom vzpostavi odnos med dvema lestvicama, lestvico argumenta in lestvico sklepa (primera (106) in (107)):

(106)

Zunaj je lepo, torej grem ven.

(107)

Ker je zunaj lepo, grem ven.

${ }^{17}$ Povzeto po: J. Moeschler, Argumentation et conversation. Éléments pour une analyse pragmatique du discours, Paris 1985, 70. 
Obazgornja primera temeljita na toposu Boljkojelepo, boljjetrebaitiven.

Kadar gre za trimestni predikat, kot na primer ampak, je vloga toposa pomembnejša. Protiargumentacijski povezovalci imajo v globinski strukturi argumentacijsko navodilo nasprotne orientacije vsebin, ki jih povezujejo, hkrati pa odločajo o argumentacijski nadrejenosti druge sestavine. ${ }^{18}$ V primeru (108) sta za uresničitev argumentacijskega dejanja nasprotnega sklepa uporabljena dva toposa (primer (109)).

(108)

Zunaj je lepo, ampak jaz sem utrujen.

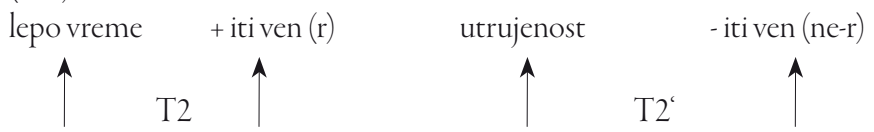

Bolj ko je lepo, bolj je treba iti ven. Bolj ko si utrujen, manj je treba itiven.

Povezovalec ampak (mais) ima v globinski strukturi dva toposa, ki nista nasprotna drug drugemu, temveč je glede na argumentacijska navodila, ki jih v sebi nosi protiargumentacijski povezovalec ampak (mais) med T2 in T2' treba izbrati $T 2$ '. Če bi govorec spremenil vrstni red sestavin (Utrujen sem, ampak je lepo), bi nas ampak primoral, da izberemo topos T2. Iz tega torej sledi, ${ }^{19} \mathrm{da} \mathrm{z}$ rabo protiargumentacijskega povezovalca ampak govorec uresniči dve argumentacijski dejanji in opravi izbiro med obema.

Toposi so pomembni tudi v diskurzivnih gibanjih. Sekundarna diskurzivna gibanja, ki niso izražena s povezovalci, so možna zaradi toposa v globinski strukturi, ${ }^{20}$ kot se da prikazati s primerom (110):

(110)

Pravzaprav tukaj v Sloveniji delamo šele deset let in moram reči, da verjetno tudi na račun slovenske zagretosti za smučanje vsako leto lahko širimo svojo distribucijo. $^{21}$

V zgornjem primeru je dopustno gibanje izraženo s členkoma šele in tudi in ne vsebuje nobenega argumentacijskega povezovalca. Zaradi topo-

\footnotetext{
${ }^{18}$ Kot je bilo že povedano pri opisu mais, ta povezovalec vedno uvaja močnejši argument.

${ }^{19}$ J. Moeschler, n. d., 71.

${ }^{20}$ A. Ellerup Nielsen, n. d., 332.

${ }^{21}$ M. Schlamberger Brezar, Zgradba pogajalske komunikacije, magistrska naloga, Ljubljana 1996 (primer: Določanje cen o smučarski opremi).
} 
sov, ki ležita v njegovi globinski strukturi in sta Manj časa delaš, slabše te stranke poznajo (TI) in Dalj časa delaš, večjo distribucijo imaš (T2), lahko to diskurzivno gibanje prepoznamo za dopustno.

Podobno je z utemeljevanjem. Glede na topos, ki ga prepoznamo v globinski strukturi (pri Diku to pomeni na ravnini predikacije, saj gre za dejanska stanja), lahko zatrdimo izrek iz primera (111). Vzročno razmerje med star in pokvariti se je določeno na podlagi toposa.

(111)

Pokvaril se mu je avto. Bil je star.

Primeri te vrste pojasnijo, zakaj tudi pri jukstapoziciji, ki jo vidimo v zgornjem primeru in kjer so povezovalci odsotni, vseeno prepoznamo določeno vsebinsko razmerje med prvim in drugim delom. J. M. Luscher celo trdi, da skladno s teorijo pertinence uporabimo povezovalce-konektorje le takrat, ko je treba razmerje med deloma izreka napraviti bolj eksplicitno. ${ }^{22}$

Nølke meni, da enako kot ilokucijska vrednost dejansko opravljena argumentacija ni nikdar precizirana v pomenu, ampak, kar je tudi značilno za ilokucijo, jezik sam v argumentacijskem dejanju ustvarja semantične omejitve, ki so zapisane v pomenu. ${ }^{23}$ Poglejmo primer (112):

(112)

Luka je bogat, ampak je poročen.

Izrek v primeru (112) ne pove ničesar o možni argumentacijski vrednosti, kljub temu pa postavlja omejitve okrog te vrednosti. Vrednost se analizira na naslednji način: Luka je bogat in Luka je poročen sta nasprotujoča si argumenta in Luka je poročen je močnejši od obeh; je torej odločilni argument. Obstaja natanko ena argumentacijska interpretacija primera (112). Že v samem gledišču izjavljalca obstajajo argumentacijske namere. Gledišče je sestavljeno iz propozicionalne vsebine in sodbe ${ }^{24}$ in je kot tako očitno epistemično modalno. Ta sodba se lahko nanaša na možno (virtualno) argumentacijo, ki jo določeno gledišče že vsebuje, torej njegovo argumentacijsko namero. V primeru (112) gre za dopustnost, ki vsebuje več gledišč. Med njimi sta si najmanj dve nasprotujoči; eno je v prid, drugo nasprotujoče kateremu koli sklepu, ki ga lahko potegnemo iz Luka je bogat (npr. dobro bi ga bilo obiskovati ...). Videli smo, da nič v izreku samem ne

\footnotetext{
${ }^{22} \mathrm{~J}$. M. Luscher, Les marques de connexion: des guides pour l'interprétation, v: J. Moeschler et al. (ur.), Language et pertinence, Zbirka Processus discursifs, Nancy 1994.

${ }^{23}$ H. Nølke, Linguistique modulaire: de la forme au sens, Louvain, Pariz 1994, 164.

${ }^{24}$ H. Nølke, n. d., 64.
} 
kaže na to, kakšen naj bi bil sklep. Zaznamovano je le dejstvo, da je sklep treba upoštevati pri interpretaciji. Očitno je povezovalec ampak tisti, ki vsili dopustno strukturo in tako priskrbi informacije, ki se tičejo orientacije argumentacijskih namer. Videli pa bomo, da ampak le izkorišča argumentacijski potencial, ki obstaja neodvisno od njega. Od moralne sodbe izjavljalca pa je odvisna interpretacija - lahko bi isti topos tudi izpodbijal in ga ne bi priznaval za veljavnega, a o tem bo govora kasneje.

Vsak povezovalec ni nujno zaznamovalec argumentacije, kar se vidi npr. $\mathrm{v}$ zvezi z in kot povezovalcem, ki služi predvsem za zaznamovalca zgradbe diskurza. Argumentacijske odnose, ki temeljijo na toposih, običajno opišemo kot odnose dveh vrst: vzročno-posledične in dopustno-protivne. V nadaljevanju si jih bomo ogledali v povezavi s slovenskimi povezovalci. Še prej pa se bomo ustavili pri definiciji diskurzivnega gibanja, ki je prav tako povezano s toposi in povezovalci.

\section{Diskurzivno gibanje}

Idejo diskurzivnega gibanja po Moeschlerju ${ }^{25}$ lahko definiramo z naslednjimi postavkami.

Pragmatični povezovalci predstavljajo sledi argumentacijske koherence v diskurzu. Diskurz je argumentacijsko koherenten, če je konvencionalno motiviran. To pomeni, da so argumentacijska navodila, ki jih dajejo povezovalci, zadostna, in da povezovalci na ustrezen način označujejo tip diskurzivne organizacije, za katerega so specializirani. Ta tip organizacije se imenuje diskurzivno gibanje. Hipoteza, ki jo s tem postavlja Moeschler, je, da povezovalci ne določajo le omejitev možnih navezav ali interpretacij argumentacijskih odsekov, ampak dovoljujejo konvencionalno uresničevanje tipičnih diskurzivnih gibanj. Iz tega sledi, da je diskurzivno gibanje treba ovrednotiti v okviru argumentacijskih in funkcijskih odnosov, ki ga določajo. ${ }^{26}$

Obstaja pa tudi strukturalna motivacija, ${ }^{27}$ kadar diskurz oziroma govorni poseg ne vsebuje vseh argumentacijskih zaznamovalcev, ki bi omogočali, da mu konvencionalno pripišemo uresničevanje diskurzivnega gibanja. Takrat govorimo o analitični ali sekundarni koneksiji oziroma o jukstapoziciji. Vendar nam nič ne preprečuje, da ne bi vstavili ustreznih argu-

\footnotetext{
${ }^{25} \mathrm{~J}$. Moeschler, Argumentation et conversation. Éléments pour une analyse pragmatique du discours, Paris 1985, 131-135.

${ }^{26}$ N. d., 133.

${ }^{27}$ N. d., 132.
} 
mentacijskih povezovalcev $\mathrm{v}$ implicitno diskurzivno gibanje in ga tako naredili eksplicitnega.

Diskurzivno gibanje je torej osnovna, prototipska struktura, ki omogoča pregled nad tvorjenjem in interpretacijo diskurza. Diskurz ni kompleksen $\mathrm{v}$ tem, da argumentacijski in diskurzivni zaznamovalci, ki jih vsebuje, zahtevajo zapletene postopke interpretacije, ampak v tem, da se osnovne diskurzivne strukture, torej argumentacijska gibanja, lahko kombinirajo med seboj v celovito sestavljen diskurz. ${ }^{28}$

Po Moeschlerju ${ }^{29}$ ločimo tri vrste diskurzivnih gibanj: posledično, dopustno in zaključno. Prvi dve si bomo ogledali v povezavi s pripadajočimi slovenskimi konektorji v nadaljevanju.

\section{Vzročno-posledični odnos}

Vzročno-posledični odnos uvajajo bodisi argumentacijski bodisi posledični konektorji.

Vsak argument potrebuje utemeljitev. Uvajajo jo vzročni vezniki, ki jim na ravni diskurza rečemo argumentacijski povezovalci. Argumentacijski povezovalci v ožjem smislu so povezovalci, ki zaznamujejo odnos argumenta do usmerjevalnega dejanja. ${ }^{30}$ Argumentacijski povezovalci uvajajo argument za določen sklep: $s$ tem zaznamujejo podrejeno dejanje in ga postavljajo v odnos z usmerjevalnim dejanjem. Podrejeno dejanje, ki ga uvajajo argumentacijski povezovalci, predstavlja vzrok, usmerjevalno dejanje pa posledico, gre torej za vzročno-posledični odnos, ki ga na drugačen način uvajajo tudi posledični povezovalci.

$\mathrm{Z}$ argumentacijskega stališča so vzročni oziroma argumentacijski povezovalci značilni za operacijo utemeljevanja. Utemeljevanje dane trditve predstavlja osnovno operacijo argumentacije, ki ne vključuje ne sklepanja, ne procesa argumentacijska gibanja, marveč le navajanje vzrokov, kar ima za posledico večjo legitimnost usmerjevalnega dejanja. Argumentacijski povezovalci so sousmerjeni. Delujejo predvsem kot zaznamovalci interakcijske funkcije, lahko pa prevzamejo tudi metajezikovno vlogo. Po Moeschlerju (1985) se argumentacijski povezovalci ne vključujejo v argumentacijska gibanja, ker zgolj prinašajo utemeljitev določene trditve.

Najpogostejši slovenski vzročni povezovalci so ker, kajti, saj in sicer. Sicer uvaja drugi argument, ki hkrati ni glavni, pač pa le dodatno pojasnilo $\mathrm{k}$

${ }^{28} \mathrm{~N} . \mathrm{m}$.

${ }^{29}$ N. d., 133.

${ }^{30} \mathrm{E}$. Roulet et al., L'Articulation du discours en français contemporain, Bern 1985, 127. 
prvemu. Ker, kajti in saj pa se razlikujejo predvsem po pomenskih odtenkih, ki jih dodajajo argumentaciji. Kajti je izrazito pisni, vendar zaradi privzdignjenosti najde pot tudi med govorce, ki bi se radi zborno izrazili, pa jim to ne gre najbolje od ust in zato posežejo po kajti, rešitvi za označevanje zgradbe diskurza in uvajanje vzroka (prim. intervjuji nogometašev in smučarjev po radiu) - medtem ko ker uvaja novo informacijo, raba saj pa temelji na konsenzu govorcev.

Oglejmo si najprej funkcioniranje povezovalca kajtiv analiziranem diskurzu.

Po SSKJ je kajti:

- veznik v vzročnem priredju za utemeljevanje, pojasnjevanje prej povedanega - Nobeden ne spi, kajti napad pričakujejo vsak trenutek.

Lahko bi rekli, da gre za zborno varianto »ker《 - nibče ne spi, ker vsak trenutek pričakujejo napad, torej bodisi uvajanje nove informacije, lahko pa tudi kot sinonim $s a j$ : v tem primeru gre za pojasnjevanje.

V korpusu Fidaplus najdemo 971 pojavitev povezovalca kajti v govorjenih besedilih (predvsem replike iz Državnega zbora). - od 100000 pojavitev v celotnem korpusu. Razmerje kaže, da je kajti predvsem rabljen v pisnem jeziku, kjer uvaja (po SSKJ) utemeljevanje, pojasnjevanje prej povedanega. $V$ primerih iz govorjenih besedil vidimo, da uvaja vzrok (primer (113)) ali pa utemeljevanje povedanega z epistemično - dokazno modalnostjo (prim. (114)) spodaj.

(113)

Tukaj bi rad povedal izkušnjo, ki jo imam, ko smo se v Idriji zelo borili, da je obstala poklicna kovinarska šola. Resnično je bilo potrebno veliko naporov s strani občine, potrebno je bilo veliko dogovorov s strani, zanimivo gimnazije, kajti ta šola je nekako delovala v okviru gimnazije. (www.fidaplus.net, Državni zbor, 1994)

Odbor se je odločil, da se ta člen črta, kajti, po mnenju odbora in seveda tudi po mnenju predlagatelja, gre v tem primeru za prekršek in seveda glavna kazen, ki je tu zagrožena za vse te tako imenovane črnograditelje, je porušenje te črne gradnje. (www.fidaplus.net, Državni zbor, 1994)

$\mathrm{V}$ teh rabah je kajti predvsem uvajalec argumentov - vzroka. V zgornjem primeru (114) je ta še dodatno opredeljen z modalno sestavino izražanja mnenja odbora (kajti po mnenju odbora gre za prekrš̌ek), ki predstavlja garant za resničnost izrekanja. 
V primeru (115) spodaj najdemo še dodatno vrednostno opredelitev povezovalca kajti, ki prinaša utemeljevanje izrekanja (kajti menimo): izjavljalec ne podaja vzrokov za to, kar pravi, ampak s kajti izjavljalec uvaja vzroke za to, da izreka dejstva, ki sledijo. Podobno je v primeru (116) spodaj.

V četrtem odstavku se pa zmanjšujejo pravice generalnega državnega tožilca, kajti menimo, glede na to, da je tožilstvo monokratski organ, ki je organiziran hierarhično, da bi personalno komisijo moral voditi generalni državni tožilec. (www.fidaplus.net, Državni zbor, 1994)

Drugo, predlagam, da se sprejmejo tudi ostala stališča, ki jih odbor predlaga, da pa vendar kakšnih dodatnih obveznosti ne bi nalagali še za to fazo spreminjanja zakona, ker se potem bojim, da tudi tistih stvari, ki bi jih zdaj želeli urediti, ne bomo tako kmalu uredili, kajti, kot rečeno, vprašanja, ki se odpirajo ob stanovanjskem zakonu, so zelo dalekosežna, zelo globoka, včasih tudi malo srce parajoča in jih bo treba v naslednjih letih še precej spreminjati. (www.fidaplus.net, Državni zbor, 1994)

Resnično vzročnih pojavitev s povezovalcem kajti v govorjenem delu korpusa Fidaplus ni zaslediti, našli smo predvsem primere za utemeljevanje izrekanja ali utemeljevanje z lastno garancijo.

Kajti na začetku izreka se pojavi 240-krat. Uvaja predvsem komentarje izrekanja (primer (117)):

\section{(117)}

Hvala za besedo, predsedujoči! Bom zelo kratek. Rad bi samo podprl predlog sklepa, ki ga je dal kolega Kocuvan, da se končno prouči in definitivno odloči, kakšne so možnosti za povezavo z Avstrijo preko Radgone. V zvezis predlogom, ki ga je dal dr. Šešerko, bi ga pa tudi zelo podprl. Če mi ne bomo imeli na tem področju tudi bolj restriktivne politike, podobno kot jo imajo v Avstrijci in drugi, potem ni pričakovati, da bi se hitro zadeve spremenile, in da bi dejansko preusmerili promet s cest na železnico. Kajti vidimo, Madžari imajo zelo liberalen režim, se lahko kar kamioni prevažajo in verjetno je tudi v tem eden od vzrokov ali pa eden glavnih vzrokov, da poskus oprtnega vlaka, ki bi vozil na relaciji iz Ljubljane proti Budimpešti, da vidimo po podatkih, ki jih je dalo Ministrstvo za promet in zveze, da je zelo slabo zaseden, in da ni ekonomske osnove za prevoze in se vlak ukine in ne bo popolnoma nič. (www.fidaplus.net, Državni zbor, 1994) 
Kajti je glede na rezultate analize v korpusu Fidaplus predvsem značilen za pisni prenosnik in zborno rabo.

Veznik ker je po SSKJ v vzročnih odvisnih stavkih za izražanje dejstva, da je vsebina stavka vzrok dogajanja v nadrednem - Ker resnice ni smel povedati, je rajsi molčal.

Druga raba z oznako ekspr. je za vzročno pojasnjevanje prej povedanega - Skrb je odveč, ker delavci so zanesljivi. Drugi primer je nenavaden za današnjo rabo.

Pri vseh rabah ker v korpusu Fidaplus pridemo do številke 100 000, v govornem prenosniku pa se ker pojavi 7820-krat.

Pri uvajanju vzroka ker prinaša novo informacijo - vzrok. V izreku uvaja temo:

(118)

Rada bi samo na kratko pojasnila. Kot se je že dogajalo v tem Državnem zboru, se tudi sedaj pač formalno ugotavlja, da je dr. Davorinu Kračunu z današnjim dnem, ko bo to Državni zbor izglasoval, prenehal mandat, ker mu pač preneha po 9. členu zakona o poslancih, to je če da odstopno izjavo.

Ker na začetku izreka beleži 1115 pojavitev. Kot smo omenili že v prvem poglavju, je ta podatek, ki je še kako relevanten za določanje statusa konektorja, žal zaradi načina transkripcije manj uporaben. Pa vendar - v tej izolirani množici se ker pojavlja v odnosu do konteksta (119) ali kot utemeljevanje izrekanja - če se že sklicujemo na v primeru (120):

Sprašujem, ali kdo zahteva spremembo ali dopolnitev, oziroma ima kakšno drugo pripombo k zapisnikom? Najprej sprašujem za zapisnik 27. seje Državnega zbora. Ker nima, prehajamo na odločanje o sprejemu zapisnika in ugotavljamo sklepčnost. Ugotovimo sklepčnost! (65 prisotnih.) (www.fidaplus.net, Državni zbor, 1995)

Ne bom pa umaknil, če bo vztrajanje pri tem, da ena komponenta, kot je rekel prej Tone Partljič, ostane, druga pa ne. Ker, če se že sklicujemo na ustavo, obe komponenti, to kar tu notri piše, vstavim tudi te druge komponente. Hvala. (www.fidaplus.net, Državni zbor, 1995)

Ker v odnosu do saj sproža razliko v razmerju tema-rema. Ker je običajno nosilec nove informacije in v diskurzu vedno predstavlja remo. Povezovalec saj pa se ponovno sklicuje na temo, že omenjeno, in išče konsenz z na- 
slovniki. Z drugimi besedami: ker poskrbi za uvajanje argumentov, saj pojasnjuje argumente, ki so znani tako izjavljalcu kot naslovniku.

Raba saj je veliko bolj razgibana kot raba ker in kajti. V SSKJ se pojavlja v naslednjih opisanih rabah:

1. v vzročnem priredju: za utemeljevanje, pojasnjevanje prej povedanega - Takoj bom vse uredil, saj to je moja dolžnost.

2. za izražanje nasprotja s prej povedanim - Pokliči očeta. Saj ga ni doma!

3. nav. ekspr., za izražanje vzročno-posledičnega razmerja - Brez plašča hodiš, saj se boš še prebladil!

4. v prisl. rabi izraža podkrepitev trditve - Kaj se zdaj razburjate? Saj sem rekel, da ne bo šlo.

5. v prisl. rabi: izraža ugotovitev, spoznanje resničnega stanja - Torej je priznal. Saj mu ni preostalo nič drugega.

6. v medmetni rabi: izraža soglasje, pritrjevanje - Niso šli dalje. Saj, vsak hip labko pridejo mimo. / opozarja na trditev v dostavku - Kajpa ona? Saj res, nje ne smemo pozabiti... / poudarja zanikanje prej povedanega - Saj nič ne rečem... saj že grem...

Saj glede na zgornjo opredelitev nastopa kot veznik in členek. Predvsem 4. raba je argumentacijsko zaznamovana - gre za konsenzualnost, deljeno mnenje, kar izpostavimo kot dejstvo (saj ste vedeli ...). V korpusu Fidaplus najdemo za povezovalec saj 1460 pojavitev v govorjenih besedilih, $\mathrm{v}$ pisnih se ponovno ustavi na 100000 . Tipičen primer rabe sredi izreka je primer (121) spodaj:

(121)

Hvala lepa, kolega Čeligoj. Slišali ste predlog, ki ga je podal Vladimir Čeligoj v imenu podpisanih poslancev. Izgleda, da nam nič ne pomaga, ker ga ne bomo mogli prebrati, saj bo treba pripraviti čistopis predloga sklepa, prebral pa ga je gospod Čeligoj. Odpiram razpravo o dodatnem predlogu sklepa.

Gospod Ivo Hvalica, izvoli. (www.fidaplus.net, Državni zbor, 1999)

Saj na začetku izreka šteje 444 pojavitev v govorjenih besedilih. Tu vključuje raznorazne pomene, ne le pojasnjevanja. Vse druži deljena informacija, konsenzualnost $\mathrm{z}$ naslovnikom, ki mu sporoča oba to veva, vsi to veste (v primerih (122), (123) in (124) in (125) spodaj). V primerih (122) in (123) gre za tipično izražanje konsenzualnosti, deljenega mnenja, v primeru (125), ki je vzet iz transkribiranega korpusa pogajalskega sporazumevan- 
ja, pa smo priča dopuščanja, kjer se saj vključuje v prvi del dopustno-protivnega diskurzivnega gibanja.

Kaj počne? - Sajveš. (www.fidaplus.net, dramsko b. - Celica)

(123)

Sajje vseeno. (www.fidaplus.net, Državni zbor, 1999)

(124)

To je bistvo. Za vsako skladiščenje, vsak prostor, ki ima na svojem nekje skladišče kakršnihkoli odpadkov, dobiva neko nadomestila. Saj ne bom rekel, da zdaj oni nekaj že ne dobivajo, ampak specifično je to, mi imamo odpadke tam in vprašanje, kako dolgo bodo. Nimate nobene rešitve, povejte, če jo imate, jaz to poznam - mislim, dobivam tudi poročila te komisije ali kako se že imenuje - in vem, da še zdaj iščejo prostore za nizko, za visoko pa sploh nič. (www.fidaplus.net, Državni zbor, 1999)

Saj se zavedam, da razbijam enotnost tečaja. Samo, nemogoče je imeti samo enomesečni tečaj. ${ }^{31}$

\section{Posledični povezovalci}

Posledični povezovalci so tisti, ki zaznamujejo usmerjevalno dejanje in vzpostavljajo odnos med le-tem in podrejenim posegom, ki ima funkcijo argumenta. ${ }^{32}$ Gre za obrnjen proces, kot smo ga prej spoznali z argumentacijskimi povezovalci. Med posledičnimi in argumentacijskimi povezovalci lahko potegnemo vzporednice, saj gre v obeh primerih za odnos vzrokposledica s to razliko, da argumentacijski povezovalci uvajajo vzrok, ki ima status argumenta, posledični pa posledico, ki ima status sklepa. Argument ima torej vedno status podrejenega govornega posega.

Vse povezovalce, ki zaznamujejo semantično polje posledičnosti, lahko razdelimo v dve skupini: med zaznamovalce dejstvene posledičnosti in zaznamovalce sklepanja. ${ }^{33}$ Razliko med prvimi in drugimi bomo prikazali s pomočjo primerov (126) (127) in (128) spodaj.

Odnos od vzroka k posledici lahko obstaja med dejstvi v izkušnjah govorečega, ${ }^{34}$ kar je razvidno tudi iz spodnjega primera (126). Diskurziv-

\footnotetext{
${ }^{31}$ M. Schlamberger Brezar, Zgradba pogajalske komunikacije, magistrska naloga, Ljubljana 1996 (primer: Pogajanje o organizaciji jezikovnega tečaja).

${ }^{32} \mathrm{E}$. Roulet et al., L'Articulation du discours en français contemporain, Bern 1985, 145.

${ }^{33}$ C. Hybertie, La conséquence en français, Pariz 1996, 2.

${ }^{34}$ C. Hybertie, n. d., 3.
} 
ni red je v takih primerih vedno usmerjen od dejstva-vzroka k dejstvu-posledici.

\section{(126)}

Il est parti depuis longtemps, SI BIEN QUE le jardin est plein de mauvaises herbes.

Že dolgo je, kar je odšel, ZATO / TAKO DA je vrt poln plevela.

Povezovalci pa lahko zaznamujejo sklepanje, to pomeni miselno operacijo, ki na podlagi dejstva, ki je dano v izkušnjah govorečega, predvidi drugo dejstvo, ki ni dano v njegovih izkušnjah. Ta navezava se uresniči kot izpeljava na dva načina (primera (127) in (128)):

(127)

Le jardin est plein de mauvaises herbes, DONC il est parti depuis longtemps.

Vrt je poln plevela, TOREJ je že dolgo, kar je odšel.

Il est parti depuis longtemps, DONC le jardin doit être plein de mauvaises herbes.

Že dolgo je, kar je odšel; vrt mora biti TOREJ poln plevela.

Navezava iz primera (127) se v vsakem primeru interpretira kot sklepanje glede na to, da gre vrstni red propozicij od dejstvene posledice $k$ dejstvenemu vzroku, saj izražanje dejstvene posledice zahteva vrstni red vzrok-posledica. Gre za miselno operacijo, ki naredi iz dejstvene posledice (vrt je poln plevela), dane v izkušnji govorečega, kazalec za dejstvo, ki bi bilo lahko vzrok za tako stanje in ki ni dano v izkušnjah govorečega, ampak mu ga znanje in izkušnje pomagajo rekonstruirati (že dolgo je, kar je odšel).

Sklepanje pa gre seveda lahko tudi od vzroka k posledici (primer (128)). Diskurzivni red propozicij v tem primeru odgovarja temu pri izražanju dejstvene posledice. Da ne gre za dejstveno posledico, ugotovimo glede na kontekst, situacijo ali še pogosteje na modalne zaznamovalce (raba prihodnjika ali pogojnika, modalni glagoli), ki jasno kažejo na sklepalno interpretacijo.

Slovenski povezovalec, ki zaznamuje dejstveno posledičnost, je zato. Zelo pogost v publicističnih besedilih je tudi podredni veznik tako da, ki običajno ne deluje kot povezovalec, a tudi izraža dejstveno posledico.

Po SSKJ ima zato dve vrednosti, prislovno in vezniško. 
Zato prisl.

I. 1. izraža vzrok dejanja, znan iz predhodnega besedila - Tu raste trta in pridelujejo vino. Najbrž so ljudje zato tako dobre volje.

//izraža utemeljitev, vzrok dejanja, kot ga določa odvisni stavek - Molčijo zato, ker se bojijo.

2. izraža namen dejanja, znan iz predhodnega besedila - Ne morete jih videti. Škoda, ravno zato sem prišel.

3. izraža ozir, zadržek, znan iz predhodnega besedila, ki ne vpliva na dejanje - Če ta jed ni izdatna, je pa zato bolj zdrava.

II. v vezniški rabi 1 . v sklepalnem priredju za izražanje vzročno-sklepalnega razmerja - Bil je zelo lačen, zato so mu dali jesti.

2. v protivnem priredju, navadno v zvezi zato pa za izražanje dopolnjevanja z nepričakovano trditvijo - Mi smo že pozabili na to zadevo, zato pa se sosedje še vedno ukvarjajo z njo.

3. v vzročnih odvisnih stavkih v zvezi zato ker - za izražanje dejstva, da je vsebina odvisnega stavka vzrok dogajanja v nadrednem stavku - Zakajje manjkal? Zato ker je bil bolan.

4. v namernih odvisnih stavkih v zvezi zato da - za izražanje namena, ki ga ima dejanje odvisnega stavka - Sedel je, zato da bi se odpočil.

Dejansko so tudi vse zgornje prislovne rabe povezovalca zato vzročnoposledične - je anaforičen in povzema vsebino, na katero se navezuje. Razlika med opredelitvijo povezovalca zato kot prislov oziroma veznik je utemeljena le v besednem redu, navezovalna vloga je enaka.

Kaj pa korpus Fidaplus? Veznik in povezovalec zato se pojavi 100.000krat v celotnem korpusu, 4846 primerov je najdenih v govorjenih besedilih, na začetku izrekov pa se pojavlja 2206-krat. Pogosto je pojavljanje v kombinaciji z zato ker, zato seveda, zato mislim, zato verjamem itd.

Zato se pojavlja tudi v kombinaciji z glagoli zato želim, zato predlagamo (primer (129) in zato menim (130)), ki izražajo dejstveno posledico in utemeljevanje miselne dejavnosti:

Jaz bi rada samo obrazložila, zakaj Vlada ta amandma predlaga. Gre v bistvu za področje zdravstva, v katerega uvrščamo to skupino delovnih terapevtov in če v bistvu spreminjamo stvari drugače, pomeni, da se potem podre tudi ta sistem v zdravstvu, ki upošteva na eni strani srednje, potem visoko medicinsko osebje, mislim medicinske sestre, nakar naprej z zdravnikom, 
sekundarjem, s specialistom itn. Tudi tu je neka lestvica, ki je logična in mislim, da če bi jo spreminjali, bi logiko te lestvice v zdravstvu podrli. Zato predlagam še enkrat, da ta amandma Vlade podprete. (www.fidaplus.net, Državni zbor, 1994)

(130)

Zato menim, da kljub temu, da se bo - pričakujem - takoj oglasil tudi minister s svojimi argumenti, bi vam še enkrat pokazal tole sliko, ki zelo jasno nakazuje slovenski prostor in ki zelo jasno pove, da bi v primeru, da to ni sprejeto, naredili genocid nad jugom. Hvala lepa. (www.fidaplus.net, Državni zbor, 1994)

Kombinacija zato, ker, ki za pisni jezik ni normativna, ker gre za mešanje vzroka in posledice, ima v govorjenih besedilih 91 zadetkov (primer (131)). V spodnjem primeru prvi zato uvaja vzrok, drugi pa posledično sklepanje.

Rad bi pa povedal tole. Povsem se strinjam s tistimi poslanci, ki mislijo, da ta zakon pravzaprav ni idealen, da ne bo rešil tega problema v skupno korist tako enih in drugih, obeh zainteresiranih strani. Točno tako je in preprosto $z a t o$, ker ta država, v tem trenutku nima tega denarja, da bi lahko to storila. To je ena izmed povsem jasnih stvari. So tudi druge možnosti, ki so tu napisane, da bi lahko do tega prišli. Zato mislim, da je ta zakon, pač odvisno, kako boste ravnali ob amandmajih, treba sprejeti. (www.fidaplus.net, Državni zbor, 1994)

$\mathrm{V}$ kombinaciji zato seveda ( 44 primerov v govorjenih besedilih) govorec izražanje gotovosti, $s$ katero jamči za resničnost argumentacije (pri$\operatorname{mer}(132))$ :

\section{(132)}

Moram povedati, da smo na odboru ugotovili, da pa vendarle ne kaže, s tem se strinjam s predlogom, da ne kaže to resolucijo zdaj v celoti zavrniti kot tako, da je treba na njej znova začeti, ampak da jo je treba samo dopolniti tam, kjer je pomanjkljiva. Mislim, da se to s strani Vlade lahko stori in se predloži takšna resolucija, kot jo je razprava danes pokazala, do naslednjega zasedanja. Če tega ni možno storiti v naslednjih dneh, gotovo pa bi morala ta resolucija na dnevnem redu, da jo kot celoto sprejmemo na junijskem zasedanju, ker smo v odboru ugotovili, da je ta resolucija, ki govori o zasnovi in izhodiščih nacionalne varnosti Republike Slovenije, vendarle vezana tudi na nekatere druge dokumente, ki bodo morali biti predloženi našemu Državne- 
mu zboru. Zato seveda ne kaže si preveč časa vzeti za to, da to resolucijo odložimo in o njej razpravljamo ne vem kdaj pozneje, ampak zagotovo vsaj na naslednjem zasedanju. Hvala. DZ 1993 (www.fidaplus.net, Državni zbor, 1993)

Povezovalca zato in torej sta med seboj v odnosu dejstveno in ne-dejstveno. Torej kot zaznamovalec sklepanja šteje 100000 pojavitev v vseh besedilih, v govorjenih 2075, na začetku izrekov 1289. Po SSKJ ima tudi ta povezovalec prislovno in vezniško vlogo kot sledi:

Torej prisl.

1. izraža vzročno-sklepalno razmerje - Zmagali so v svoji skupini in bodo torej igrali v finalu.

2. izraža navezovanje na prej povedano - Kaj torej še hočeš?

3. ekspr., izraža začudenje, nejevoljo, nestrpnost, zavrnitev - Torej povej, kaj misliš. No torej, poberi se že.

4. v medmetni rabi izraža spodbudo, poziv - Torej, le pojdi. Torej, kaj siprinesla?

Torej vezn.

1. v sklepalnem priredju za izražanje vzročno-sklepalnega razmerja Pozni smo, torej gremo čim prej dalje.

2. z oslabljenim pomenom za dopolnjevanje, pojasnjevanje prej povedanega - Predstava bo prvega, torej v nedeljo.

Prav tako kot zato je torej anaforičen, pojavlja pa se kot sklepalni povezovalec tako v pisnih (primer (133)) - na začetku vprašanj - kot govorjenih besedilih (primer (134)).

Kako torej na Očaka z otroki? Vzpon nanj nikakor ni mačji kašelj. Potomce peljemo tja le v družinskem krogu, kadar se starši in otroci dobro zavedajo resnosti in težavnosti takega podviga. $V$ vršnem delu nad Kredarico ali Planiko je nujno otroka navezati, ga opremiti s čelado in ga ustrezno varovati. Vzemimo si vsaj tri dni časa in pohod skrbno pripravimo. Mlademu gorniku podrobno razložimo, kaj ga čaka na poti. Priprave pričnimo več tednov pred odhodom, najbolje kar spomladi na začetku planinske sezone. Na vedno daljših izletih v gore postopoma pridobivajmo ustrezno telesno pripravljenost. (www.fidaplus.net; pisna besedila, Večer 1996)

In zelo jasno je, da je TAM moral prevzeti tudi neke večje stroške reševanja presežnih delavcev, da je v ta namen porabil 822 milijonov tolarjev, da je Mi- 
nistrstvo za delo, družino in socialne zadeve prispevalo pri trajnih presežkih 605 milijonov tolarjev, kar pomeni nekje okoli 42\%, torej ne 100\%, in da tudi za to seveda potrebuje izpolnitev te tretje tranše. (www.fidaplus.net; DZ 1995) (www.fidaplus.net, Državni zbor, 1995)

Med povezovalci, ki zaznamujejo sklepanje, so pri Toporišiču ${ }^{35}$ poleg torej navedeni še zatorej, tako in tedaj. Zatorej se v korpusu Fidaplus pojavlja $4311 \mathrm{v}$ vseh besedilih, v govorjenih pa le 5-krat, kar kaže na pešajočo rabo. Tega SSKJ ne omenja, a tudi sicer je opis rabe skrčen na dve vrstici:

Zatorej-prisl.zato

- v vezniški rabi - Pogovarjala se je z vsakim in o vsaki stvari, zatorej so jo ljudje imeli radi.

Primer rabe v govorjenih besedilih:

Vidite, zato menim, da mi lahko odločimo samo o nekaterih (generaliziram zdaj) osnovnih dejstvih. Prvič, da želimo biti odvezani od te solidarnostne klavzule, da smo pri tem dosegli maksimum kar smo mogli, približno, več ali manj. Samo ti dve vprašanji zahtevata naš jasen odgovor, ki morata biti pa podprti s tem strokovnim gradivom, ki mora biti tudi z druge strani prevrednoteno in pregledano. In potem mora priti, po mojem mnenju, ob tako pomembni odločitvi kot je ta, pred ta zbor vsaj tudi predsednik Vlade in osebno zastaviti svojo avtoriteto in reči: za tem stojim! Vsega tega pa ni. In zatorej prihajamo zopet v tak položaj, da Vlada ostaja anonimna za nekim pomembnim predlogom, enim najpomembnejših, in ga tako rekoč kot kost vrže Državnemu zboru, da o njem odloča, kar strokovno ne more. (www.fidaplus. net, Državni zbor, 1996)

Prej so navedeni vzroki, zato uveljavlja sklep (sklepalno-posledično diskurzivno gibanje). Posledični povezovalci se združujejo v posledična diskurzivna gibanja. Moeschler ${ }^{36}$ pravi: Če govorimo o posledičnem diskurzivnem gibanju, se to uresniči v diskurzu d, če:

1. je $\mathrm{d}$ sestavljen iz najmanj dveh sestavin $\mathrm{cl}$ in $\mathrm{c} 2$, kjer imata $\mathrm{cl}$ in $\mathrm{c} 2$ lahko status govornega posega ali govornega dejanja;

2. c1 se predstavlja s ciljem argumentirati v prid sklepa r;

3. c2 predstavlja izrekanje argumentacijskega sklepa r;

${ }^{35}$ J. Toporišič, Slovenska slovnica, Maribor 2000, 433.

${ }^{36} \mathrm{~J}$. Moeschler, Argumentation et conversation. Éléments pour une analyse pragmatique du discours, Paris 1985, 133-134. 
4. c2 motivira s samim izrekanjem argumentacijsko funkcijo c1.

Osnovna značilnost posledičnosti je argumentacijska enosmernost, saj v gibanju ne prihaja do nobene kontradikcije. Spominja na utemeljevanje, ki ga zagotavljamo z rabo vzročnih veznikov, vendar pri utemeljevanju Moeschler meni, da tam ne gre za vzročno gibanje, pač pa samo za govorni poseg, ki daje trditvi več legitimnosti, tehtnosti in resničnosti. V slovenščini tako diskurzivno gibanje na splošno uvajajo argumentacijski povezovalci ker, kajti, saj. Nasprotno pa Ellerup Nielsen dokazuje, da tudi vzročnost predstavlja argumentacijski odnos. ${ }^{37}$ Vzročni zaznamovalci služijo različnim argumentacijskim namenom in se vključujejo v prepričevalne strategije. Odnos lahko prepoznamo tudi, ko je izražen analitično (primer (109) zgoraj). A. Ellerup Nielsen (n. m.) dokazuje, da temelji na toposu. daj:

Primera posledičnih diskurzivnih gibanj (136) in (137) navajamo spo-

(136)

A: Dobro veš, da šola trpi.

B: Zakaj trpi?

A: Trpi zato, ker je te nove ljudi treba vključevati v skupine, ki že imajo neko predznanje. $^{38}$

(137)

A:En moment - zame je cena C nesprejemljiva, ker ne pokriva niti materialne baze.

B: $m h m \ldots$

C: Tako da... pod ceno D se skoraj ne morem pogovarjat... ${ }^{39}$

\section{Dopustno-protivni ali protiargumentacijski povezovalci}

Protiargumentacijski povezovalci v slovenščini so čeprav, četudi, a, ampak, vendar, toda, samo, le. Podrobnejša analiza pokaže, da v okviru protiargumentacijskih povezovalcev ločimo dva razreda, dopustne in protivne povezovalce: med dopustne spadajo čeprav, četudi in še kak členek, med protivne $a$, ampak, vendar, toda, samo, le, kljub temu pa za vse zgoraj naštete veljata naslednji dve točki:

\footnotetext{
${ }^{37}$ A. Ellerup Nielsen, The Argumentative Impact of Causal Relations - An Exemplary Analysis of the Free Predicate in the Promotional Discourse, Argumentation 10 (1996), 333-335.

${ }^{38}$ M. Schlamberger Brezar, Zgradba pogajalske komunikacije, magistrska naloga, Ljubljana 1996 (primer: Pogajanje o organizaciji jezikovnega tečaja).

${ }^{39}$ M. Schlamberger Brezar, n. d. (primer: Določanje cen o smučarski opremi).
} 
1) protiargumentacijski povezovalci vežejo interakcijska dejanja, ki imajo med seboj semantični, argumentacijski ali pragmatični odnos protislovja, ${ }^{40}$ hkrati pa to kontradikcijo rešujejo v notranjosti govornega posega;

2) to kontradikcijo pragmatično razrešujemo $z$ ilokucijskimi ali interakcijskimi funkcijami, kot so zavračanje argumenta, zavračanje dejstva ali ugotavljanja določenega protislovja, ki so splošno imenovani tudi dopuščanje, izpodbijanje, proti-dejstvenost.

Semantično lahko odnos, ki ga uvajajo protiargumentacijski povezovalci, označimo kot implikacijo med $p$ in ne-q. Argumentacijske značilnosti so povezane $\mathrm{z}$ naravo nasprotja med $p$ in $q$. Odnos je posreden, če se vzpostavi glede na implicitne sklepe $p$ in $q$, ter neposreden, če so sklepi izpeljivi iz $p$ in $q$. Samo mais predstavlja možnost posrednega odnosa (primer (138)):

\section{(138)}

Il pleut, mais jai envie de prendre l'air.

Dežuje, ampak rad bi šel na zrak.

$\mathrm{V}$ zgornjem primeru sta $p$ in $q$ podana $\mathrm{z}$ nasprotujočimi si sklepi: na podlagi $p$ (dežuje) bi sklepali na ostal bom doma. Na podlagi $q$ ( rad bi šel na zrak) pa sklepamo na šel bom ven. Drugi sklep prevlada in predstavlja sklep dopustnega diskurzivnega gibanja.

$\mathrm{Na}$ splošno protiargumentacijski povezovalci nastopajo $\mathrm{v}$ treh funkcijah: tev $p$ );

1) v funkciji zavračanja argumentacijske usmeritve ( $q$ izničuje usmeri-

2) v funkciji ugotavljanja protislovja ( $q$ ukinja veljavnost odnosa med $p$ in ne-q, ne da bi ga izničil);

3) v funkciji dejstvenega zavračanja ( $q$ zanika dejstvo, ki ga označuje propozicija $p$ ).

\section{SLOVENSKI DOPUSTNO-PROTIVNI ZAZNAMOVALCI IN DOPUSTNO-PROTIVNO ARGUMENTACIJSKO GIBANJE}

Nosilci argumentacije v jeziku, operatorji in konektorji, se združujejo v dopustno-protivno argumentacijsko gibanje v dveh fazah: prva faza prina-

\footnotetext{
${ }^{40} \mathrm{~V}$ filozofiji se uporablja tudi poimenovanje kontradikcija: gre za odnos, ki predstavlja diagonalo v logičnem kvadratu.
} 
ša dopuščanje določenega argumenta, medtem ko druga prinaša nasprotni argument, ki prevlada. ${ }^{41}$

Tretja podskupina argumentacijskih povezovalcev so protiargumentacijski povezovalci. Zanje je značilno, da uvajajo dopustno argumentacijsko gibanje $d$, ki je sestavljeno iz dveh delov $c l$ in $c 2 .{ }^{42}$ Ta dva dela sta po Moeschlerju (n. m.) bodisi govorni dejanji bodisi govorna posega. Prvi del $c 1$ je predstavljen s ciljem argumentirati v prid zaključku $r$, ki je nujno impliciten. To je dopustni del, s katerim se naslovniku dopušča možnost, da so njegovi argumenti ustrezni. Drugi del $c 2$ je predstavljen $s$ ciljem argumentirati v prid zaključku $\neg$ r. Del $c 2$ ne postavlja pod vprašaj informacijske relevance $c 1$, ampak postavlja pod vprašaj argumentacijsko relevanco $c 1 . \mathrm{Z}$ drugimi besedami: ko izjavljalec uporabi $c 2$, se mu ta zdi močnejši argument za sklepe, ki bi jih rad prikazal, kot $c l$. Tako je nujno, da iz $c l+c 2$ potegnemo zaključek $\neg r$. Propozicija, govorni poseg ali govorno dejanje, ki ga uvaja $c 2$, je protiargumentacijsko. Za prikaz dopustnega argumentacijskega gibanja smo izbrali primera (139) in (140) spodaj:

Že že, saj se zavedam, da s tem razbijam enotnost tečaja, samo nemogoče je imeti samo enomesečni tečaj. ${ }^{43}$

A: Naša mreža res pokriva velik del celotnega tržišča.

B: Že $e \check{z} e$, ampak ko je Slovenija tak mali trg. ${ }^{44}$

Segment $c l$ je v prvem primeru Že že, saj se zavedam, da stem razbijam enotnost tečaja. Ta segment ima po Ducrotu in Anscombru virtualno argumentacijsko vrednost. ${ }^{45}$ Določen izrek lahko predstavlja možen argument, ki pa ga ne izkoristimo za argumentiranje. Tak primer so dopustni stavki: v svojem izreku že že, saj se zavedam, da stem razbijam enotnost tečaja, govorec najprej izrazi strinjanje s prejšnjim izrekom sogovorca, nato pa s protivnim povezovalcem uvaja nove argumente, ki govorijo $\mathrm{v}$ prid nasprotnemu sklepu in hkrati imajo status močnejšega argumenta. V primeru (139) torej izbiramo med možnim in odločilnim argumentom c2. ${ }^{46}$ Sklep iz pri-

\footnotetext{
${ }^{41}$ J.-C. Anscombre, O. Ducrot, L'Argumentation dans la langue, Bruselj 1983, 31.

${ }^{42} \mathrm{~J}$. Moeschler, Argumentation et conversation. Éléments pour une analyse pragmatique du discours, Paris 1985, 133.

${ }^{43}$ M. Schlamberger Brezar, Zgradba pogajalske komunikacije, magistrska naloga, Ljubljana 1996 (primer: Pogajanje o organizaciji jezikovnega tečaja).

${ }^{44}$ M. Schlamberger Brezar, n. d. (primer: Določanje cen o smučarski opremi).

45 J.-C. Anscombre, O. Ducrot, L'Argumentation dans la langue, 31-32.

${ }^{46}$ Po Ducrotu in Anscombru (n. m.) sev francoščini glasi: »argument possible et argument décisif«.
} 
mera (139) se po danem govornem posegu glasi: moramo imeti tudi štirinajstdnevne tečaje.

V slovenščini prvi del, segment $c l$, uvajajo povezovalci oziroma operatorji dopustnosti že, že res, to že, ki vsebujejo govorčevo dopuščanje tega, kar pravi sogovorec, pa tudi njegovo omejevanje do priznavanja te trditve in anticipirajo neko nasprotno trditev, poleg njih pa še:

1) členki: že, saj, no

2) prislovi v vlogi argumentacijskih zaznamovalcev: res, gotovo.

Tako se slovenski členki vključujejo v argumentacijska gibanja in delujejo kot povezovalci. Največkrat jih srečamo v vlogi zaznamovalcev zgradbe diskurza, kjer nastopajo kot intonacijsko ločeni pastavki (primer (141), no in saj):

$N o, \downarrow s a j, s a j$, to je v redu, da pač vi, če se potem ta računalnik pokvari, nam daste nov računalnik ${ }^{47} . .48$

Segment c2 pa navadno uvajajo protivni vezniki oziroma povezovalci: pa, ali, toda, a, ampak, vendar, temveć, marveč, samo, le. Prvih pet je veznikov, drugih pet členkov, vsi pa se v diskurzu realizirajo kot povezovalci.

\section{VKLJUČEVANJE TOPOSOV}

Dopustno-protivno argumentacijsko gibanje vedno vključuje dva toposa: prvi del, ki je tako rekoč enak vzročno-posledičnemu odnosu, in drugi del, ki prinaša novo interpretacijo, ki prvo zavrača - ji je diametralno nasprotna. Protivne veznike in povezovalce bi lahko opisali kot in $+v$ nasprotju spričakovanji. ${ }^{49}$

Glavna značilnost dopustnega diskurzivnega gibanja je, da predstavi argumentacijsko kontradikcijo in jo $\mathrm{v}$ sami predstavitvi razreši in tako omogoči tvorbo diskurza $d$, ki je argumentacijsko koherenten in sam v sebi brez nasprotij. Tu običajno nastopa polifonija, kjer govorec ponovi trditev sogovorca - če gre za pisni jezik, pa pisec vnaprej predvidi možno reakcijo sogovorca. ${ }^{50}$

\footnotetext{
${ }^{47}$ Kot transkripcijski oznaki puščici $\uparrow \downarrow$ označujeta rastočo ali padajočo govorno intonacijo.

${ }^{48}$ M. Schlamberger Brezar, n. d. (primer: Pogajanja o ceni popravila računalnika).

${ }^{49}$ M. Riegel, J. C. Pellat, R. Rioul, Grammaire méthodique du français, Pariz 1994.

${ }^{50}$ Polifonijo podrobno obravnava Igor Ž. Žagar v prvem delu te knjige, zlasti v poglavjih Med argumentacijo in polifonijo; Kako napravimo kaj z besedami-polifoni način in Pa, modifikator veznikov.
} 


\section{SLOVENSKI PROTIARGUMENTACIJSKI POVEZOVALCI IN NJIHOVA VLOGA V DISKURZU}

Od bliže si bomo ogledali protivne veznike oziroma povezovalce $a$, ampak, le, samo, toda in vendar.

Po SSKJ je $a$ opisan na naslednji način:

$A$ (vez., knjiž.)

1. v protivnem priredju za izražanje

a) nasprotja s prej povedanim; pa, toda, vendar-Prej so ga radi imeli, a zdaj zabavljajo čezenj

b) nepričakovane posledice.

//za omejevanje

2. redko v vezalnem priredju.

Problem pri korpusnem raziskovanju a je, da se v vzorcu prikažejo tudi vsi drugi a-ji, npr. členkovni vprašalni, končniški (DARS-a, TAM-a) ali enostavno zaznamovalci hierarhizacije v besedilu (člen 23 a)) (vsi primeri www.fidaplus.net). Najdemo 100000 pojavitev nediskriminirano, 1909 v govorjenih besedilih, vendar je vmes ogromno takih, ki so nevezniški (Dars-a, TAM-a, Člen 3 a) in podobno) oziroma členkovni - vprašalni ( $A$ kako naj zagotovo vem? (www.fidaplus.net; Državni zbor 1993) in podobno. Tako sta primera (142) in (143) s sinonimnim veznikom v dveh različnih funkcijah - v primeru (142) gre za povezovalec $a$, ki ga težko povsem razčlenimo, ker v korpusu manjka celoten predhodni del, v primeru (143) pa za $a$ - naklonski členek.

A BO VSE HUJE. PROBLEM JE. (www.fidaplus.net; Čudoviti um dramsko besedilo)

$\mathrm{KAJ}$ ? A NAJ VŽGEM? JA. (www.fidaplus.net; Ali G Indahause - dramsko besedilo)

Od redkih primerov povezovalca $a$ iz replik v državnem zboru naj navedemo primera (144) in (145):

Liberalni demokrati smo bili vedno za stroko in za uravnoteženje. Zato bomo seveda glasovali za ta amandma. Ker lovci so sicer izjemno blagega srca do divjadi kakor pravijo sami, a samo, če pogledamo število tako imenova- 
nih uplenjenih kosov divjadi, lahko vidimo seveda, da gre v $90 \%$ za čisto komercialno zgodbo, ki z ekosistemom in drugimi funkcijami gozda ni v neposredni povezavi. Zato je seveda logično, da bomo mi glasovali za amandma. (www.fidaplus.net; Državni zbor 1993)

Ne vem, zakaj le en del razumnikov misli, da bodo tisti, ki so bili pripravljeni umreti za Slovenijo, sedaj to isto Slovenijo res prodali za lire in šlinge. Ne bojim se ne za slovenstvo, ne zaradi razprodaje slovenstva, o kateri tako čustveno, a zavestno manipulirajo mnogi posamezniki. Bojim pa se za Slovenijo in slovenstvo zaradi tega - res pa, da včeraj nisem bil prisoten ves čas - ker se mi zdi, da vse te dni ni bila spregovorjena niti ena beseda o slovenski kulturi, ki je gotovo močnejše identifikacijsko sredstvo kot zemlja sama... (www.fidaplus. net; Državni zbor 1997)

$\mathrm{V}$ primerih (144) in (145) zgoraj je a sinonimen z ampak in ima vlogo protiargumentacijskega povezovalca. Vlogi sta nekoliko različni: $a \mathrm{v}$ primeru (144) predstavlja minimalni pogoj za nasprotovanje trditvi lovcev samih, da so blagega srca do živali: sledi dopustno argumentacijsko gibanje - če samo pogledamo število uplenjenih kosov divjadi, se ponuja sklep, ki je nasproten $\gg$ ljudem z blagim srcem « in zatrjen v nadaljevanju. Drugi primer (145) druži dva pridevnika v nasprotju: čustveno, a zavestno. Protiargumentacijski povezovalec $a$ sicer lahko zamenjujemo z ampak, pa vseeno skriva nove različice interpretacije.

Pri povezovalcu in vezniku ampak v korpusu Fidaplus najdemo od 100 $000 \mathrm{v}$ celotnem korpusu 4385 pojavitev ampak v govorjenih besedilih. Od tega jih 725 začenja izrek z veliko začetnico. Te zadnje so prave diskurzivne funkcije povezovalca, kjer ampak za končnim ločilom odpira govorni poseg.

SSKJ pri ampak loči med prislovno in vezniško rabo na naslednji način: Ampak prisl.

Pog., v medmetni rabi

1. izraža veliko mero - Ampak smo imeli srečo!

2. izraža začudenje, nejevoljo - Ampak da je to mogoče!

Ampak vez.

1. za uvajanje nove trditve namesto prej zanikane - Ne piše za mladino, ampak za odrasle.

2. nav. ekspr., v zvezi ne samo, ampak tudi; za širjenje, stopnjevanje prej povedanega - Ni le svetoval, ampak tudi pomagal. 
3. ekspr., za izražanje nasprotja s prej povedanim - Lep je, ampak drag.

4. pog. ekspr., na začetku odstavka za opozoritev na prehod k drugi misli - Ampak pogovarjajmo se rajši o čem drugem!

Za ampak, ki ga v SSKJ imenujejo prislov, bi po Ducrotu ${ }^{51}$ uporabili izraz »fatični ampak«. Ducrot ga je v francoščini opisal na podlagi analize komedije Mais occupe-toi d'Amélie. To je povezovalec ampak, ki se navezuje na kontekst in izraža, da je dogajanje nesprejemljivo oziroma v nasprotju z običajnim (po Adamu 1985). Ta tip mais se v francoščini nahaja v glavnem na začetku in se navezuje bodisi na nov govorni poseg bodisi na nebesedni kontekst. Lahko tudi zaključuje govorni poseg brez eksplicitnega nadaljevanja. $\mathrm{Na}$ isti način bi lahko interpretirali ampak da je to mogoče! ali ampak smo imeli srečo! iz slovarskega članka SSKJ. Fatičnih primerov v govorjenih besedilih korpusa Fidaplus je največ v dramskih besedilih (Ampak Billy...) (Stepfordske ženske) V isti drami najdemo še druge pojavitve fatičnega ampak: Ampak zaslužim, Ampak imela sem delo, Ampak hodik psibiatru, ki jih zaradi pomanjkanja konteksta pred pojavitvijo ne moremo natančneje interpretirati.

Podobno interpretacijo zasluži tudi primer (146) spodaj, kjer se sprašujemo, ali je ampak sploh protiven. Prej bi rekli, da gre za navezovanje na prej povedano, torej fatično vlogo.

(146)

Kdor se spomni teh neskončnih sholastičnih diskusij o lastninjenju, saj problem je bil razdelitev te družbene lastnine. Ker se je skozi to mislilo, da se bo skozi to razdelitev dobila pač nova - oblikovala nova politična struktura. To je dejansko tudi tako. Ampak veste, pri teh diskusijah smo po mučnih letih, dveh ali ne vem koliko letih, dveh parlamentov, treh Vlad prišli do konsenza, ki bo potem čez nekaj mesecev zopet spremenjen. (www.fidaplus.net; Državni zbor 1994)

Sicer pa so vrednosti ampak - veznika, ki ne nastopa na začetku izreka, v korpusu predvsem protivne:

(147)

Razpravo sem dovolil zato, ker ta sklep seveda ni zgolj proceduralne narave, ampak rešuje vsebinski zaplet, do katerega je prišlo. Vendar bi rad povedal naslednje. (www.fidaplus.net; Državni zbor 1998)

Pri primerih povezovalca ampak na začetku izreka v precej primerih namesto dopustnega argumentacijskega gibanja dobimo komentar izre-

${ }^{51}$ O. Ducrot et al., Les mots du discours, Paris 1980. 
kanja v zvezah ampak mislim, ampak poglejte, kot je razvidno iz primerov (148) in (149) spodaj:

\section{(148)}

Hvala lepa. Gospod predsedujoči, spoštovane kolegice in kolegi! Jaz bi prosil in želel, če bi lahko vlada pred državnim zborom pojasnila svoj zadnji predlog. Moram reči, da sem mnenja, da je to pač eden od zelo tipičnih primerov načina našega dela, pa ta trenutek se ne spuščam v vsebino, ker se bom v vsebino spustil, ko bom dobil pojasnila. Ampak poglejte, gospa predsednica odbora za zdravstvo, družino, delo in socialno politiko je povedala, da je matično delovno telo menilo, da je vprašanj, kako urediti dodatno zdravstveno zavarovanje veliko različnih pogledov, stališč in skupen dogovor z vlado, da naj se vendar določene stvari dopolnijo. Vlada nam je 26. februarja pisno odgovorila, da je sklenila, da državnemu zboru ne predlaga amandmajev $\mathrm{kza}$ konu. (www.fidaplus.net; Državni zbor 1998)

Če ta predlog ne bi bil sprejet, bom dal seveda na glasovanje predlog gospoda Toneta Anderliča, da se zakon ne sprejme. Ampak mislim, da po opravljeni razpravi, moram kot predsedujoči in kot svoj predlog predlagati, da se vrne zadeva matičnemu delovnemu telesu. (www.fidaplus.net; Državni zbor 1998)

Naslednji primer pa prej kot protivno razmerje izraža utemeljevanje nasprotovanja:

Jaz se z gospodom ministrom povsem strinjam, da nikakor ne gre za to, da bi podcenjevali stopnjo v našem izobraževalnem sistemu, samo, če bi pa iz tega izpeljali tezo, da smo lahko zadovoljni s tem, kar imamo, tu se pa seveda zelo zelo razhajamo in o tem bi se dalo zdaj argumentirati, zelo na dolgo argumentirati v čem so. Ampak ne gre za to. Gre za to, da poizkušamo, izhajajoč iz tega, kar imamo, da uveljavljamo nekatere strukturne organizacijske spremembe, da bi pravzaprav učinkovitost tega šolanja še povečali. (www.fidaplus.net; Državni zbor 1995)

Analiza povezovalca ampak v korpusu Fidaplus tako izkazuje precej raznolike funkcije, ki sicer vse združujejo protiargumentacijsko vsebino, vendar se ta izraža ne le v navezavah na topose, ampak meri tudi na kontekst, izrekanje in utemeljevanje ali komentar izrekanja.

Operatorja in veznika oziroma povezovalca samo in le sta delno sinonimna. Po Slovenski slovnici »ta dva veznika iz jedra vezniške zveze nekaj iz- 
vzemata. /.../Veznik le je manj navaden kot samo. Samo se rabi tudi namesto vendar.$^{52}$ Pri le, kjer se celotno število pojavitev ustavi na 100000 , jih v govornem prenosniku v korpusu Fidaplus najdemo 1491. Minimalno število jih je v vlogi konektorja, v glavnem gre za operator, kar smo predstavili v poglavju o členkih zgoraj, kjer tudi navajamo opredelitve SSKJ (kot leprislov). Za le $\mathrm{v}$ funkciji povezovalca je $\mathrm{v}$ SSKJ samo tale omemba:

Le-vezn.

V protivnem priredju za omejevanje - Govori lepo, le malo pretiho.

Spodnji primer prikazuje le v stopnjevalnem vezniškem razmerju ne le, ampak tudi (sinonimen $\mathrm{z}$ ne samo, ampak tudi).

$(151)$

Vlada meni, da so izjave gospoda Antona Drobniča take vrste, teže in narave, da ne sodijo v današnje čase, saj so zaradi njih lahko prizadetih številni Slovenci, ki dan upora proti okupatorju praznujejo ne le kot državni, ampak tudi kot svoj praznik. (www.fidaplus.net; Državni zbor 1998)

Sicer je prevladovala vloga le kot operatorja. ${ }^{53} \mathrm{Z}$ danimi orodji v korpusu Fidaplus pa ločevanja na operatorje in veznike po korpusu žal ne moremo opraviti.

Podobno tudi samo v opredelitvi v SSKJ kot prislov, za nas členek, obravnavamo pri členkih oziroma operatorjih. Samo kot veznik oziroma povezovalec in operator šteje 5422 pojavitev v korpusu v govorjenih besedilih Fidaplus, samo na začetku izrekov pa 665 pojavitev, med katerimi je še vedno veliko rabe operatorjev. V primeru (152) spodaj je prvi samo zaimek, drugi pa povezovalec, sinonimen z ampak. V primeru (153) pa imamo dva povezovalca.

Hvala lepa. Malo repliciram gospodu ministru, ampak ne iz zlobe, ampak mogoče zato, da bomo nekatere stvari malo bolje razumeli. Okolje lahko poskrbi samo za sebe, samo človeka ne sme biti zraven. Vsi se strinjamo, da lahko eno dolino zapremo, da ljudje ne bodo vanjo hodili; ni problem. Drevo, ki se posuši in tam segnije, pač tam segnije; divja žival... (www.fidaplus.net; Državni zbor 1999)

${ }^{52}$ J. Toporišič, Slovenska slovnica, Maribor 2000, 440.

${ }^{53}$ Le kot operator smo podrobno opisali že v poglavju Slovenski členki med argumentacijskimi operatorji in konektorji. 
(153)

To je prav. Samo mislim, da tukaj manjka neka koncepcija, po kateri bi bilo mogoče izvesti sistematično že od otroškega vrtca naprej le neko razlikovanje in da bi prišli tako do tistega relativno majhnega števila nadpovprečno nadarjenih otrok. Mislim, da se nam ni potrebno sramovati, če ugotavljamo, da so otroci pač različno nadarjeni. Mogoče je marsikaj narediti v šolskem sistemu, zato je šolski sistem tudi tukaj, samo tistih osnovnih razlik ne smemo zanemariti. Zato se nagibam k temu, da bi mi le razmislili tudi tu v okviru Državnega zbora. (www.fidaplus.net; Državni zbor 1995)

Kot najstanovitnejši protiargumentacijski veznik in povezovalec v korpusu Fidaplus se izkaže toda. Po SSKJ ni pretirano polisemičen, kot sledi v nadaljevanju:

\section{Toda vezn.}

1. $\mathrm{v}$ protivnem priredju za izražanje

a) nasprotja s prej povedanim - Rekel je, da bo pomagal, toda obljube ni izpolnil.

b) nepričakovanega;

//za omejevanje - Veliko bere, toda samo pustolovske knjige.

2. na začetku (od)stavka za opozoritev na prehod k drugi misli - Toda pogovarjajmo se o čem drugem.

Beseda toda v vseh prenosnikih se ustavi na 100000 pojavitvah, od tega jih je na začetku povedi oziroma izreka 83876. Je izrazito pisni povezovalec z le 382 primeri v govorjenem diskurzu (od tega jih je 183 s toda na začetku izreka). Primeri v govorni in pisni rabi se bistveno ne razlikujejo in ne odstopajo bistveno od opredelitve v SSKJ, njihovo delovanje je precej enotno - ne glede na to, ali se toda pojavlja na začetku izreka ali v sredini. Za primerjavo podajamo primera (154) in (155):

\section{(154)}

Pred seboj imamo sistemski zakon, ki ureja pravice za vse državljane in za vse tujce in je popoln nesmisel, tudi v pravnem pogledu, da sistemski zakon podrejamo potrebam dnevne politike. Tehnično je vse mogoče v zakone napisati, toda nikakor ni to konsistentno z ostalo zakonodajo. Rešljivo je na zelo eleganten način, toda ne na tak način, da bi po vsej sili vgradili v zakon določila nekega mednarodnega dogovora. To ne gre. (www.fidaplus.net; Državni zbor 1996) 
(155)

Opravičujem se vsem tistim, ki menite, da nisem dal dovolj konkretnih odgovorov, kajti še enkrat poudarjam, če bil zdaj marec ali maj, da bi bilo smiselno zelo natančno odgovarjati, zakaj je kje odvzet denar in zakaj ni dan. Toda zdaj je praktično december, konec novembra in se na cestnem delu kaj dosti več ne da narediti. (www.fidaplus.net; Državni zbor 1997)

$\mathrm{V}$ primerih govorjenega diskurza najdemo nekaj kombinacij toda s prislovi in drugimi zaznamovalci modalnosti (dejstvo je, sprašujem se, verjamem), toda vendarle -2 pojavitvi, toda mislim - 3 pojavitve, toda dejstvo je - 6 pojavitev, toda dejansko - 6 pojavitev. Tu govorec dodaja svojo zavezanost vsebini, ki jo izraža tudi tale primer:

(156)

Jaz ga tudi razumem na svoj način in ga tudi lahko razlagam na svoj način.

Toda dejstvo je, da je to slabo za neko zakonsko dikcijo. Zakonska dikcija

mora biti taka, da se jasno razume in da ni sporov, kajti potem si jo bo sodišče

spet po svoje razlagalo itn. (www.fidaplus.net; Državni zbor 1994)

Med operatorji in povezovalci deluje tudi členek vendar. Po SSKJ je vendar:

I. prisl.

1. izraža nasprotje s prej povedanim - Kajpa, če vendar pride.

2. z oslabljenim pomenom izraža nejevoljo, nestrpnost - Odprivendar. Kajpa vendar počenjaš.

//izraža veselje, presenečenje - $O$, si vendar prišla.

3. ekspr., z oslabljenim pomenom: poudarja samoumevnost povedanega - Fant je vendar zadosti star.

//poudarja povedano nasploh - To vendar ni nič težkega.

II. v vezniški rabi v protivnem priredju

1. za izražanje nasprotja s prej povedanim.

2. za omejevanje prej povedanega - Naj poskusi, vendar se bojim, da ni prepozno.

V funkciji operatorja deluje vendar - med členkom in veznikom oziroma prislovom - podobno kot saj ter izraža konsenzualnost in določeno čustveno vrednotenje v odnosu do konteksta, kot kažeta tale primera: 
(157)

Vendar si mu ušla. (www.fidaplus.net; dramsko besedilo, Kralj škorpijonov) (158)

SAJ SI VENDAR TAKO ČISTA. (www.fidaplus.net; dramsko besedilo Kremenčkovi Viva Rock Vegas)

Ali primer iz Državnega zbora (159), kjer je vendar tudi operator:

Naj vendar pride hitro dol sicer vedno pripravljen gospod Baškovič, pa naj tu pove, ali je kršen poslovnik, ali ni. Grobo je kršen in celo hitri postopek. Pa kdo je vse to naredil? Kako? Na kakšen način? (www.fidaplus.net; Državni zbor 1996)

V korpusu Fidaplus je bilo 2268 pojavitev vendar v govorjenih besedili. Vendar na začetku izrekov nastopa samo v funkciji povezovalca (primer (160) spodaj), takih pojavitev je bilo 679.

(160)

Ob taki politiki, ne more podpirati stvari, s katerimi se potem sama tolče po glavi. Mislim, da Slovenija mora jasno izbrati. Napraviti eno dobro strategijo do slovenske manjšine ne glede na ideološko opredelitev, paziti na njene potrebe. Bil je že izdelan osnutek za podpore. Želja bi bila, da bi ta zakon šel. Vendar moramo upoštevati to, da mi moramo zahtevati od $\gg$ mati «, od države v kateri živimo, finančna sredstva. Slovenija nam mora biti le v oporo, kot pomoč. Ker drugače se bo zgodilo, da bomo samo pri matični domovini zahtevali sredstva in bomo zanemarjali to kar bi morala italijanska država. (www.fidaplus.net; Državni zbor 1995)

Tudi pri vendar najdemo precej pojavitev v povezavi z drugimi zaznamovalci, npr. modalnimi izrazi: vendar menim, (primer (161), vendar pa (223 ponovitev, primer (162) spodaj)), vendar mislim ( 17 pojavitev v celotnem korpusu, primer (163) spodaj). Glagola menim, mislim, izražata govorčevo zavezanost temu, kar trdi v izreku, medtem ko pa poudari protivnost izreka.

Posebej se v to sicer nisem poglabljal, vendar menim, da je v resnici izredno pogumno dejanje, da predsednik DARS-a trdi, da roki niso ogroženi, kajti za uresničitev nekaterih rokov, predvsem teh trojanskih, bo potrebno plačati višjo ceno, kot bi jo, če bi nekoliko bolj preudarno delali v preteklih letih, predvsem v lanskem letu in deloma tudi v letošnjem. (www.fidaplus.net; Državni zbor 1996) 
(162)

Dejstvo pa je seveda tudi to, da so vsi ti delavci, ki so izgubili delovna mesta takrat, po eni strani pridobili pravico do denarnih nadomestil, dejstvo je, da takrat ni bila mogoča prisilna poravnava, in seveda dejstvo je, da so vsi ti delavci lahko uveljavljali terjatve v postopku stečaja. Vendar pa se strinjam z gospodom Henigmanom, da je verjetno med njimi tudi kdo, ki ni mogel v celoti ali pa ni izterjal vseh terjatev iz naslova neizplačanih plač. Vendar pa kljub temu menimo, da ni osnove bilo v samem zakonu, da bi sprejeli posebno pravico za nazaj. (www.fidaplus.net; Državni zbor 1997)

(163)

Zato mislim, da je materija prav gotovo napotilo, ali pa bom rekel smer, v katero se nakazuje reševanje zadev v tem amandmaju, odlična, dobra. Vendar mislim, da zasluži vsaj nekaj členov in čeprav nisem zagovornik besedičenja pa množice zakonov, mislim, da bi bila stvar prav v redu lahko urejena v nekaj členih enega posebnega zakona. (www.fidaplus.net; Državni zbor 1995)

Predvsem dopustna argumentacijska gibanja vključujejo veliko povezovalcev, ki so si podobni po funkciji, pa vendar nekoliko različni po pomenu in v odnosu do konteksta. Vidimo pa, da se na izrekanjski ravni povezovalci praviloma kombinirajo še z zaznamovalci za epistemično modalnost, ki izražajo govorčevo zavezanost vsebini, ki jo izreka.

\section{Dejanska argumentacija v analiziranem diskurzu}

Preučevanje argumentacije v jeziku je temeljilo na Ducrotovi in Anscombrovi tezi o argumentaciji v jeziku. Argumentacija v jeziku se izraža z operatorji, povezovalci, toposi. Anscombre in Ducrot predvidevata, da argumentirati predvsem pomeni utemeljiti vsebino določenega sklepa. »Tretji člen« argumentacije je »pot« argumenta do sklepa. Topos oziroma uporabljeno načelo argumentacije je na drugem mestu in ima za edino nalogo, da omogoča utemeljitev; da zapolni to, kar ločuje argument od sklepa in da ga tako napravi neovrgljivega. Če se tu pojavljajo izjeme, je to naključno; to je neke vrste anomalija.

Globinski argumentacijski odnosi so večinoma izraženi s toposi. Kadar v povezavi z njimi nastopajo argumentacijski povezovalci, jih lahko razumemo kot navodila, kako naj govorec dani topos interpretira. Kadar je topos sam dovolj močan oziroma razviden za govorca in govorec meni, da tudi za naslovnika, prvi ne uporabi nobenega povezovalca. To se dogaja predvsem, ko gre za dopustna gibanja, kjer že jukstapozicija zadostuje za interpretacijo odnosa, ki ga je govorec želel vzpostaviti. Toposi so dani že od ravnine predikacije oziroma dejanskega stanja dalje. Po eni strani nam 
omogočajo, da podajamo vrednostne sodbe in izrekamo izreke $\mathrm{z}$ vzročnoposledično oziroma dopustno-protivno vsebino brez rabe povezovalcev, po drugi strani pa omogočajo zdrs pomena povezovalcev v nove smeri, ne da bi pri tem bilo moteno razumevanje.

$\mathrm{Za}$ analizo tega, kako poteka dejanska argumentacija v diskurzu, se je treba vrniti $k$ interpretaciji povezovalcev in toposov kot nosilcev argumentacije v jeziku. Analizirani diskurz je glede na Ducrotovo opredelitev argumentacije $v$ jeziku nedvomno argumentacijski. Ne moremo o nečem govoriti, ne da bi temu pripisali značilnost, lastnost, funkcijo, argumentacijsko usmeritev. V tem smislu je vsako izrekanje način, kako predstavimo stvari in kako predstavimo odnos govorca do sveta in do drugih.

Po pregledu delovanja povezovalcev lahko zaključimo, da v večini primerov, tudi če niso rabljeni v celotni logični argumentacijski shemi, izražajo argumentacijsko namero, ki je povezana $\mathrm{z}$ osnovnim pomenom povezovalca. Tako so tudi rabe večine povezovalcev, ki delujejo kot zaznamovalci strukturacije diskurza, argumentacijske.

Vsi ti povezovalci - zaznamovalci strukturacije diskurza pa poleg tega, da na eni strani razrešujejo kontradikcije tako, da se vključujejo v diskurzivna gibanja, na drugi strani pa izražajo odnos do sogovorca. Ta odnos do sogovorca je pogosto še poudarjen z izrekanjskimi prislovi, ki so epistemično modalni. Glede na to, da se argumentacija ne ukvarja z resničnostjo, ampak le $\mathrm{z}$ verjetnostjo in močjo argumentov $\mathrm{v}$ prid verjetnim trditvam, so modalna sredstva v kombinaciji s povezovalci pomembna, saj izražajo večjo oziroma manjšo zavezanost resničnosti izrečenega. Modalni zaznamovalec predstavlja garant za resničnost sodbe, ki jo izjavljalec izreka oziroma kaže, v kolikšni meri je govorec pripravljen garantirati za resničnost sodbe.

Analizirana argumentacijska besedila izvirajo iz avtentičnega diskurza. Tu se argumentacija ne odvija samo na predikacijski in propozicijski ravni, pač pa je dodana tudi na izrekanjski ravni. Konektorji se tudi kombinirajo z modalnimi prislovi, ki izražajo sodbo ali dokaznost in zaznamujejo stopnjo zavezanosti resničnosti tistemu, kar izjavljalec trdi. Ta stopnja zavezanosti predstavlja garant za sklepanje na podlagi izrečenega. Vidimo, da v govorjenih besedilih povezovalcem sledi še utemeljevanje izrekanja. Tu bi se lahko približali Toulminovemu modelu argumentacije in ga dopolnili z: jaz sem garant za to, kar izrekam. Slovenski ustrezniki za zaznamovalce strukturacije, na katere lahko sklepamo na podlagi analiziranih slovenskih avtentičnih diskurzov, so členki, ki združujejo modalno in argumentacijsko vlogo. 
$\mathrm{V}$ analizi govorjenega diskurza na podlagi omejenega korpusa smo priča naslednjim težnjam:

- uporablja se manj povezovalcev kot v pisnem jeziku, ti povezovalci izgubljajo logično funkcijo in delujejo na ravni zaznamovalcev strukturacije diskurza, argumentacijski pomen pa očitno ostaja.

- topos sam po sebi je lahko zadosten temelj za vzpostavljanje argumentacijskega razmerja, kar bi lahko utemeljevali s teorijo relevance: kjer je razmerje vzpostavljeno že s toposom in je za izjavljalca (ter naslovnika) jasno, ni potrebe po povezovalcu. Če pa razmerje ni jasno razvidno, govorec uporabi povezovalec, ker s tem omogoči naslovniku hitrejšo in točnejšo interpretacijo.

$\mathrm{V}$ analizi zaznamovalcev argumentacije $\mathrm{v}$ jeziku dobimo občutek, da se argumentacija seli na področje odnosov, ki jih imajo izjavljalci do povedanega in do sogovorcev: tu gre predvsem za primere, ko podlaga za argumentacijo v toposu ni dana in jo izjavljalec vzpostavlja s povezovalcem. Argumentacija temelji na osebnih mnenjih: na tej točki jo podprejo modalni zaznamovalci. Govorec ne uporabi le ampak, in ter ker, temveč ampak mislim, ampak dejansko, in v resnici, ker gotovo. Dejanska argumentacija se ne odvija na področju logične argumentacije; tega, kar je logično, ni treba argumentirati, saj je jasno razvidno in dokazovanje ni potrebno. Dejanska argumentacija v diskurzu se odvija na področju medsebojnega delovanja govorcev. Ni resnice, je le gotovostna dimenzija, ki ti jo je v izmenjavi pripravljen nuditi sogovorec. 

Actes de langage et structure de la conversation. Cahiers de linguistique française 1. Université de Genève, Ženeva 1980.

Anscombre, J.-C., De l'énonciation au lexique: mention, citativité, délocutivité. Langages XX/80 (1985), 9-34.

Anscombre, J.-C. et al., Théorie des topoï. Kimé, Pariz 1995.

Anscombre, J.-C. in Ducrot, O., L'Argumentation dans la langue. Mardaga, Bruselj 1983.

Anscombre, J.-C. in Ducrot, O., Deux mais en français? Lingua 43 (1977), 23-40.

Anscombre, J.-C. in Ducrot, O., Pour soigner le minimalisme. Journal of Pragmatics (1986), 10, 435-440.

Aristotle, Art of Rhetoric. Harvard University Press (Loeb Classical Library), Cambridge, London 1926/1991.

Austin, J. L., Performatif-Constatif. V: La philosophie analytique. Minuit, Pariz 1962.

Austin, J. L., Sense and Sensibilia. Oxford University Press, Oxford 1962.

Austin, J. L., Philosophical Papers. 2. izd. Clarendon Press, Oxford 1970.

Austin, J. L., How to Do Things With Words. 2. izd. Oxford University Press, Oxford 1984.

Bakhtin, M. (pod imenom V. N. Volosinova), Marxism and the philosophy of language. Seminar Press, New York 1973. 
Bakhtin, M., Discourse in the novel. The dialogic imagination. Four essays. University of Texas Press, Austin 1981.

Bakhtin, M., Problems of Dostoevsky's Poetic. University of Minnesota Press, Minneapolis 1984.

Benveniste, E., Problemi splošne lingvistike I. Studia Humanitatis, Ljubljana 1988.

Berrendonner, A., Eléments de pragmatique linguistique. Minuit, Pariz 1981.

Bourdieu, P., Ce que parler veut dire. Fayard, Pariz 1982.

Cadiot, A., Ducrot, O., Nguyen, T.-B., Vicher, A., Sous un mot, une controverse: Les emplois pragmatiques de 'Toujours'. Modèles linguistiques VII (1985), 2, 105-124.

Cicero, De oratore. Harvard University Press (Loeb Classical Library), Cambridge, London 1942/1988.

Cicero, De partitione oratoria. Harvard University Press (Loeb Classical Library), Cambridge, London 1942/1992.

Cole, P. (ur.), Pragmatics. Academic Press, New York 1978.

Coulmas, F., Conversational Routine: Explorations in Standardized Communication Situations and Prepatterned Speech. Mouton De Gruyter, Haag 1981.

Černelič, I., Členek kot besedna vrsta v slovenskem knjžnem jeziku. Jezikoslovni zapiski 1.ZRC SAZU, Ljubljana 1991,73-85.

Černelič-Kozlevčar, I., O delitvi členkov. Vprašanja slovarja in zdomske književnosti. Zbornik Slavističnega društva Slovenije 3. Zavod RS za šolstvo in šport, Ljubljana 1993, 213-227.

Delo, 11. VI. 1988, 3. IX., 7. IX., 21. IX., 2. XI. 1990.

Dik, S. C., The Theory of Functional Grammar. Part I: The structure of the clause. Foris, Dordrecht 1989.

Dik, S. C., The Theory of Functional Grammar, Part II: Complex and derived constructions, ur. Kees Hengeveld. Mouton de Gruyter, Berlin, New York 1997.

Ducrot, O., Dire et ne pas dire. Herman, Paris 1972.

Ducrot, O., La preuve et le dire. Mame, Paris 1973.

Ducrot, O., Structuralisme, énonciation et sémantique. Poétique 33 (1978).

Ducrot, O., Les échelles argumentatives. Minuit, Paris 1980. 
Ducrot, O. et al., Les mots du discours. Minuit, Paris 1980.

Ducrot, O., Note sur l'argumentation et l'acte d'argumenter. Cahiers de linguistique française 4 (1982).

Ducrot, O., Opérateurs argumentatifs et visée argumentative. Cabiers de linguistique française 5 (1983).

Ducrot, O., Le dire et le dit. Minuit, Paris 1984.

Ducrot, O., Predavanja na EHESS (zapiski, neobjavljeno), 1986-90.

Ducrot, O., L' énonciation et polyphonie chez Charles Bally (1986). V: Ducrot, O. (ur.), Logique, structure, énonciation. Minuit, Pariz 1989.

Ducrot, O., Izrekanje in izrečeno. Studia Humanitatis, Ljubljana 1988.

Ducrot, O. (ur.), Logique, structure, énonciation. Minuit, Pariz 1989.

Ducrot, O., Peut-on séparer sémantique et pragmatique. Manuscript, 1992.

Ducrot, O., Topoï et formes topiques. V: Anscombre, J.-C.et al. (ur.), Théorie des topoï. Kimé, Pariz 1995.

Ducrot, O., Slovenian lectures/Conférences slovènes. ISH, Ljubljana 1996.

Ellerup Nielsen, A.,The Argumentative Impact of Causal Relations - An Exemplary Analysis of the Free Predicate in the Promotional Discourse. Argumentation 10 (1996), 243-268.

Fann, K. T. (ur.), Symposium on J. L. Austin. Routledge \& Kegan Paul, London and Henley 1979.

Ferbežar, I. et al., Sporazumevalni prag za slovenščino 2004. Center za slovenščino kot drugi/tuji jezik, Ljubljana 2004.

Gilbert, D., La logique et quotidien. Minuit, Pariz 1984.

Glonar, J., Slovar slovenskega jezika. Umetniška propaganda, Ljubljana 1936.

Gorjanc, V., Konektorji v slovničnem opisu znanstvenega besedila. Slavistična revija 46/4 (1998), 367-388.

Gorjanc, V., Kohezivni vzorec matematičnih besedil. Slavistična revija 47/2 (1999), 139-160.

Grgič, M. in Žagar I. Ž., Čas in dejanje v jeziku: oblikovanje performativne teorije na Slovenskem. Oranžna zbirka, Založba /*cf., Ljubljana 2004.

Gross, G. in Piot, M. (ur.), Syntaxe des connecteurs. Langue française 77 (1988).

Gumperz, J. J., Discourse Strategies. Cambridge University Press, Cambridge 1982. 
Hybertie, C., La conséquence en français. Ophrys, Pariz 1996.

Larochebouvy, D. A., Essais sur la Convérsation Quotidienne. Didier-Credif, Pariz 1984.

Logique, Argumentation, Conversation. Peter Lang, Bern, Fribourg 1983.

Luscher, J. M., Connecteurs et marques de pertinence, l'exemple de d'ailleurs. V: Cahiers de linguistique française 10. Ženeva 1989.

Luscher,J.M.,Les marques de connexion: des guides pourl'interprétation«. V: Moeschler J. et al. (ur.), Language et pertinence. Zbirka Processus discursifs. PUN, Nancy 1994.

Lycan, W. G., Logical Form in Natural Language. M.I.T., Cambridge, Massachusetts 1984.

Lyons, J., Semantics. Cambridge University Press, Cambridge 1977.

Malinowski, B., The problem of meaning in primitive languages. V: Ogden, C. K. in Richards, I. A. (ur.), The meaning of meaning: A study of the influence of language upon thought and the science of symbolism. Harcourt Brace Jovanovich, New York 1923.

Meyer, M. (ur.), De la Méthaphysique à la Rhétorique. Université de Bruxelles, Bruselj 1986.

Moeschler, J., Argumentation et conversation. Élémentspour une analyse pragmatique du discours. Hatier-Crédif, Paris 1985.

Moeschler, J., Les connecteurs pragmatiques. V: Reboul, A. in Moeschler, J. (ur.), Pragmatique du discours. Armand Collin, Pariz 1998.

Moeschler et al., Language et pertinence. Zbirka Processus discursifs. PUN, Nancy 1994.

Morel, M. A., La concession. Ophrys, Paris 1996.

Morel, M.A. in Danon-Boileau, L., La grammaire de l'intonation: Exemple du français. Ophrys, Paris-Gap 1998.

Nølke, H., Linguistique modulaire: de la forme au sens. Editions Peeters, Louvain, Pariz 1994.

Palmer, F. R., Mood and Modality. Cambridge University Press, Cambridge 1986.

Perelman, Ch. in Olbrechts-Tyteca, L., Traité de l'argumentation - La nouvelle rhétorique. Editions de l'Université de Bruxelles, Bruxelles $1958 / 1983$.

Plantin, C., Essai sur l'argumentation. Kimé, Pariz 1990. 
Platon, Theaetetus (prev. H. N. Fowler). Harvard University Press (Loeb Classical Library), London, Cambridge 1924.

Prichard, H. A., The Obligation to Keep a Promise, (1940). V: Prichard, H. A., Moral Obligation. Oxford University Press, Oxford 1965.

Prichard, H. A., Moral Obligation. Oxford University Press, Oxford 1965.

Quintilian, Institutio oratoria. Harvard University Press (Loeb Classical Library), Cambridge, London 1921/1953.

Reboul, A. in Moeschler, J., Pragmatique du discours. Armand Collin, Pariz 1998.

Récanati, F., Les sens des mots. Critique 128/130 (1986), 464-465.

Recherches pragmatiques sur le discours. Cabiers de linguistique française 9. Université de Genève, Ženeva 1988.

Riegel, M., Pellat, J. C., Rioul, R., Grammaire methodique du francais. PUF, Pariz 1994.

Roulet, E., Speech Acts, Discourse Structure and Pragmatic Connectives. Journal of Pragmatics 8 (1984), 31-47.

Roulet, E. et al., L'Articulation du discours en français contemporain. Lang, Bern 1985.

Schiffrin, D., Discourse Markers. Cambridge University Press, Cambridge 1988.

Schlamberger Brezar, M., Zgradba pogajalske komunikacije. Magistrska naloga. Univerza v Ljubljani, Filozofska fakulteta, Ljubljana 1996.

Schlamberger Brezar, M., Vloga povezovalcev v diskurzu. V: Štrukelj, I. (ur.), Jezik za danes in jutri, Zbornik referatov na II. kongresu Društva za uporabno jezikoslovje, Ljubljana 1998.

Schlamberger Brezar, M., Le rôle des topoï dans la négociation conversationelle. Linguistica XXIX (1999), 123-135.

Schlamberger Brezar, M., Vpliv pragmatičnega jezikoslovja na raziskave slovenskega jezika: primer členkov. V: Jan, Z. (ur.), Slovensko jezikoslovje danes in jutri, Zbornik Slavističnega društva Slovenije 10. Zavod Republike Slovenije za šolstvo, Ljubljana 1999.

Schlamberger Brezar, M., Les connecteurs en combinaison avec les marquers modaux: l'exemple du français et du slovene. Linguistica XL/2 (2000), 273-282. 
Schlamberger Brezar, M., Skladenjski in pragmatični vidiki povezovalcevv francoskih utemeljevalnih besedilih. Doktorska disertacija. Univerza v Ljubljani, Filozofska fakulteta, Ljubljana 2000.

Schlamberger Brezar, M., Vloga povezovalcev v govorjenem diskurzu. Jezik in slovstvo 52 (2007), 3/4, 21-32.

Schlamberger Brezar, M., The connection between topoi and connectives in French political discussions. V: van Eemeren, F. H., Williams, D. C., Žagar, I. Ž. (ur.), Understanding argumentation: work in progress. Sic Sat, Amsterdam 2008.

Schlamberger Brezar, M., Francoske televizijske debate - načini ustnega argumentiranja v primerjavi s klasičnimi pisnimi shemami. Šolsko polje XIX, 3/4 (2008), 131-155.

Slovar slovenskega knjižnega jezika. SAZU/DZS, Ljubljana 1975, 1985, 1986.

Strawson, P. F., Intention and Convention in Speech Acts, (1969). V: Fann, K. T. (ur.), Symposium on J. L. Austin. Routledge \& Kegan Paul, London, Henley 1979.

Sperber, D. in Wilson, D., Relevance - Communication and cognition. Basil Blackwell, Oxford 1986.

Tancig P. in Žagar, Ž. I., Računalniško podprta analiza velikih tekstualnih baz podatkov: primer 'napadov na JLA'. V: Štrukelj, I. (ur.), Uporabno jezikoslovje. Ljubljana 1989.

Toporišič, J., Slovenski jezik 1-4. Obzorja, Maribor 1966.

Toporišič, J., Kratko oblikoslovje slovenskega knjižnega jezika. V: Kmecl, M., Logar, T., Toporišič, J., (ur.), Slovenski jezik, literatura in kultura: informativni zbornik, Seminar slovenskega jezika, literature in kulture pri Oddelku za slovanske jezike in književnosti Filozofske fakultete Univerze v Ljubljani, Ljubljana 1974.

Toporišič, J., Slovenska slovnica. Obzorja, Maribor 1976.

Toporišič, J., Enciklopedija slovenskega jezika. Cankarjeva založba, Ljubljana 1992.

Toporišič, J., Slovenska slovnica. Obzorja, Maribor 2000.

Toulmin, S.E., The Uses of Argument. Cambridge University Press, Cambridge 1958/1995.

Van Dijk, T. A., Studies in the pragmatics of discourse. Mouton, Paris, New York 1981. 
Van Dijk, T. A. (ur.), Discourse as Structure and Process. Sage, London 1997.

Van Dijk, T. A. (ur.), Discourse as Social Interaction. Sage, London 1997.

Verschueren, J., The Lexicalization of Linguistic Action. V: Proceedings of the Seventh Annual Meeting of the Berkeley Society 7 (1981), 328-335.

Verschueren, J., Basic Linguistic Action Verbs. Cabiers de linguistique française 2. Université de Genève, Ženeva 1981.

Verschueren, J., Understanding Pragmatics (manuscript). 1998.

Žagar, I. Ž., Zagatnost performatiunosti ali kako obljubiti. DZS, Ljubljana 1989.

Žagar, I. Ž., How to do things with words - The polyphonic way. V: Žagar, I. Ž. (ur.), Speech acts: Fiction or reality. Inštitut za družbene vede, Ljubljana 1991.

Žagar, I. Ž., Argumentacija v jeziku proti argumentaciji z jezikom. Anthropos III/IV (1991), 172-185.

Žagar, I. Ž., 'Pa', the reverser of argumentative expectation. Filozofski vestnik 12/1 (1991), 179-192.

Žagar, I. Ž., O polifoniji, argumentativnem pričakovanju in njegovem sprevračanju. Ćasopis za kritiko znanosti 140/141 (1991), 111-130.

Žagar, I. Ž., Performativnost kot polifonija. Anthropos 24, št. 5/6 (1992), 125-134.

Žagar, I. Ž., Argumentation in language and the Slovenian connective 'pa'. Antwerp Papers in Linguistics 84. University of Antwerp (UIA), Antwerp 1995.

Žagar, I. Ž., From reported speech to polyphony, from Bakhtin to Ducrot. V: M. Javornik (ur.), Bakhtin and the humanities. Proceedings of the International Conference, October 19-21, 1995. ZIFF, Ljubljana 1997.

Žagar, I. Ž., Argumentation in the Language-system or Why Argumentative Particles and Polyphony are Important for Education. Šlsko polje X, 3/4 (1999), 159-171.

Žagar I.Ž., From Topos to Locus to Topos: Between Aristotle and Ducrot. V: van Eemeren, F.H., Grootendorst, R., Blair, J.A., Willard, Ch. A. (ur.), Proceedings of the Fourth International Conference of the International Society for the Study of Argumentation. Sic Sat, Amsterdam 1999.

Žagar, I. Ž., Topoi: črna skrinjica argumentacije. Šolsko polje 18, 7/8 (2007), 73-98. 
Žmavc, J., Terencijev animus: analiza pomenskega polja. Keria 4/2 (2002), 117-130.

Žmavc, J., Ethos and pathos in Anaximenes' Rhetoric to Alexander: a conflation of rhetorical and argumentative concepts. V: van Eemeren, F. H., Williams, D. C., Žagar, I. Ž. (ur.), Understanding argumentation: work in progress. Sic Sat, Amsterdam 2008.

\section{Spletni viri}

FidaPlus, korpus slovenskega jezika: www.fidaplus.net (datum dostopanja: od aprila do junija 2009).

Nova beseda, besedilni korpus na Inštitutu za slovenski jezik Frana Ramovša ZRC SAZU: http://bos.zrc-sazu.si/s_beseda.html.

Krek, S. in Arhar, Š., Priporocila za oblikoslowno označevanje JOS. Dodatek B.9. Členek.: http://nl.ijs.si/jos/msd/html-sl/josMSD-sl-back.1_ div.2_div.9.html (datum dostopanja, junij 2009) 
kazalo

A

anafora 111,124

argumentacija, nelinearnost 17,18 argumentacija, polemičnost 17,25 argumentacijska namera 175,178 , 179, 204

argumentacijska orientacija, gl. ar-

gumentacijska usmerjenost, argumentativna usmeritev 6, 132, $133,139,177$

argumentacijska usmerjenost, argumentativna usmeritev, gl. argumentacijska orientacija 16,17 , $18,22,23,24,27,28,29,33,34,37$, $53,54,67,74,75,76,77,99,100$, 102, 103, 111, 123, 132, 133, 138, $142,176,192,204$

argumentacijsko gibanje 6, 10, 133,

136, 138, 148, 150, 152, 180, 192,

193, 194, 196, 197, 203

argumentativna (argumentacijska)

vrednost 16, 24, 42, 130, 131, 132, 139, 142, 169, 178, 193 argumentativna lestvica 18, 23, 24, $26,27,28,29,61,77,89,93,100$, $101,102,173,176$

argumentativna moč $18,20,21,22$, $26,27,28,53,101,102$

argumentativni modifikator 17,99 , 111, 123, 124, 194

argumentativni niz $31,33,35,41$, $42,43,59,62,67,73,75,76,77$,

$101,104,115$

avtor (v teoriji polifonije) 37, 38, 86, 109, 110

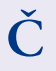

členek 10, 37, 42, 95, 109, 127, 128, $129,130,131,132,133,135,140$, 143, 152, 155, 191, 194, 199, 204

\section{D}

dejstvenost 15, 16, 19, 21, 23, 31, 35, $78,185,186,187,189,192$ dejstvo 15, 16, 24, 32, 35, 36, 46, 52, $58,59,67,74,78,79,111,175,186$, 192 
dialogizem 37

diskurz 18, 19, 24, 53, 61, 62, 66, 67, $70,72,86,100,109,133,153,154$, $155,156,163,164,169,172,179$, $180,183,204$

diskurzivna metafora 99 diskurzivni segment 59,89, 104, 105, $106,111,112,114,115,124$

diskurzivno gibanje 138, 150, 169, dokaz 57 $177,178,179,180,190,191,204$

dokazovanje 17

E

entimem $46,53,54,56,57$

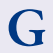

govor $16,21,45,90$

govorec $17,37,38,41,46,60,85,86$, $87,90,93,109,110,113,117,120$, 130, 141, 169, 172, 173, 175, 203, 204

govorica $37,38,90$

I

ilokucijska moč 84, 88, 90, 93, 105 ilokucijsko dejanje 84,85

implicitno 18, 46, 50, 100, 106, 111, 133,174

implikatura 53, 114, 121, 122

indikator, gl. veznik, konektor, povezovalec 9

informativnost $16,19,21,22,23,24$, $34,35,77,103$

intenca $84,85,86$

intencionalno dejanje 85

izjava $15,17,18,19,20,21,22,23,24$,

$31,34,37,38,39,41,42,58,59,61$,
$62,69,72,73,74,75,82,84,85,86$,

$87,88,90,93,103,109$

izjavljalec $17,38,41,42,43,71,86,87$, $90,93,109,110,120,178,179,193$, 204, 205

izjavljalni položaj $38,39,43,88,109$, $117,118,120$

J

jezik 16, 24, 34, 50, 71

K

konektor, gl. povezovalec, indikator, veznik 10, 131, 133, 134, 135, 136, 138, 146, 148, 150, 151, 152, 153, 154, 161, 167, 176, 178, 180, $183,192,199,204$

kontekst 18, 22, 23, 32, 34, 35, 36, 37, 39, 40, 41, 67, 69, 70, 71, 72, 73, 74, $75,79,100,103,109,128,130,131$, $141,152,154,156,159,170,186$, 197, 201, 203

konvencija 84, 85, 86 konvencionalno dejanje 85 kvalifikator $50,52,58$

\section{L}

logika 17, 18, 25, 28, 45, 87, 90, 99, $100,103,154,156,172$

\section{0}

operator $9,10,74,77,78,99,124,127$, 130, 131, 132, 133, 134, 135, 136, 141, 143, 148, 149, 150, 151, 152, $153,154,156,158,176,192,194$, 198, 199, 201, 202, 203 
P

performativ $39,40,83,84,86,88,89$, 90, 91, 93

performativnost 81,84

pertinentnost $24,86,178$

polifona analiza $39,42,43,110$

polifona interpretacija $81,84,88$

polifona struktura 37, 109, 111, 118, $122,123,124$

polifonija 5, 23, 31, 33, 35, 37, 38, 39, $41,42,43,45,47,53,74,75,88$,

109, 194

pomen/smisel 21

postavka/predpostavka 19, 20, 21 povezovalec, gl. konektor, indika-

tor, veznik 10, 130, 131, 148, 153,

155, 156, 157, 158, 162, 163, 165,

$169,176,177,179,180,184,185$,

186, 187, 189, 190, 192, 194, 195,

197, 199, 200, 201, 203, 205

premisa $17,18,46,53,55,57,58,99,172$ propozicija $54,129,153,155,156,157$,

159, 169, 176, 186, 192, 193

propozicionalna vsebina $87,89,93$,

$105,128,130,178$

\section{$S$}

silogizem $17,25,56,57,59,100$

skalarnost 23, 24, 29, 45, 46, 47, 48, $49,50,51,52,59,60,61,62,67,100$

sofisti 54

stavek/izjava 21

$\mathrm{T}$

teorija argumentacije v jeziku

(TAJ) 9, 15, 21, 24, 31, 53, 72, 99, 100, 103, 110, 131, 152, 175 teorija govornih dejanj 81,84

topična oblika/forma $62,64,65$

topike 55, 56, 68

topoi, gl. topos 45, 50, 54, 55, 56, 57 ,

$58,59,60,100,101,110$

topos 10, 23, 24, 25, 26, 27, 28, 29,

$42,43,46,47,54,55,56,57,58$,

$59,60,61,62,63,64,65,100,101$,

$102,103,110,111,122,138,150$,

159, 161, 169, 171, 172, 173, 174,

$175,176,177,178,179,191,194$,

203, 205

V

veznik, gl. indikator, konektor, povezovalec $9,10,32,33,35,36,37$, $67,78,88,95,99,100,102,103$, 104, 105, 106, 109, 111, 115, 117, $118,119,120,123,124,153,158$, $180,194,200$

\section{Z}

zaznamovalec zgradbe diskurza 130 

kazalo

A

Anaksimen 54,214

Anscombre 10, 47, 131, 152, 153, 159,

$171,172,175,193,203,207,209$

Aristotel 46, 54, 55, 56, 60, 171, 172

Auctor ad Herennium 56

Austin 83, 84, 85, 88, 90, 91, 93, 207, 208, 209, 212

B

Bakhtin 37, 38, 42, 43, 207, 208, 213

Bally 93, 209

Benveniste 84, 208

Berlin 90

Berrendonner 208

Bourdieu 90, 208

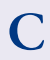

Cadiot 41, 88, 208

Chomsky 10

Cicero 57,208

Cole 208

Coulmas 208
Černelič-Kozlevčar 128, 129, 208

\section{D}

Danon-Boileau 157, 210

de Saussure 21, 23, 53

Dik 127, 157, 174, 178, 208

Ducrot 5, 9, 10, 11, 13, 15, 19, 20, 21, 22, 23, 24, 25, 28, 29, 31, 34, 37, 38, $39,41,42,43,45,46,47,53,54,59$, $61,62,63,64,66,72,76,81,86$, $87,88,93,99,100,101,103,109$, 110, 131, 132, 133, 140, 141, 152, $153,155,159,169,171,172,173$, 175, 193, 197, 203, 204, 207, 208, 209,213

E

Ellerup Nielsen 175, 177, 191, 209

F

Fann 85, 209, 212

Ferbežar 127, 129, 130, 131, 209

Fowler 211 
G

Gilbert 209

Glonar 209

Gorgias 54

Gorjanc 154, 209

Grgič 90, 209

Gross 209

Gumperz 209

\section{$\mathrm{H}$}

Hengeveld 157

Hybertie 185, 210

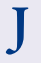

Jan 127, 211

Javornik 42, 213

K

Kmecl 128, 212

Kvintilijan 46, 57,211

L

Larochebouvy 210

Logar 128, 212

Luscher 154, 178, 210

Lycan 210

Lyons 159, 210

M

Malinowski 69, 210

Meyer 210

Milošević 16,17

Moeschler 10, 18, 132, 154, 158, 173, $175,176,177,178,179,180,190$, 191, 193, 210, 211

Morel 157, 175, 210

\section{N}

Nguyen 41, 88, 208

Nølke 156, 178, 210

$\mathrm{O}$

Ogden 210

Olbrechts-Tytéca 58, 210

P

Palmer 147, 210

Pellat 156, 194, 211

Perelman 58,210

Piot 155, 156, 209

Plantin 10,210

Platon 81, 211

Prichard 90, 91, 92, 93, 211

Protagoras 54

R

Reboul 158,210, 211

Récanati 211

Retorika za Aleksandra 54

Richards 210

Riegel 156, 194, 211

Rioul 156, 194, 211

Roulet 10, 154, 175, 180, 185, 211

$S$

Schiffrin 211

Schlamberger Brezar 4, 6, 9, 10, 11, 127, 129, 131, 135, 146, 153, 154, 157, 177, 185, 191, 193, 194, 211, 212 Sperber 154, 212

Strawson 84, 85, 212

Strawsonova daljica 84, 89

Štrukelj 131, 154, 211, 212 
$\mathrm{T}$

Tancig 212

Teofrast 46

Terencij 53, 54, 214

Toporišič 128, 129, 130, 131, 155, 190, 199, 212

Toulmin 46, 48, 49, 50, 51, 52, 58, 59, $62,169,204,212$

V

Van Dijk 69, 70, 71, 72, 154, 212, 213

Van Eemeren 54, 212, 213, 214

Verschueren 71,213

Vicher 41, 88, 208

W

Williams 54, 212, 214

Wilson 154,212

Z

Žagar 5, 10, 13, 23, 39, 42, 43, 54, 86, $90,95,169,171,172,194,209,212$, 213,214

Žmavc 9, 53, 54, 214 




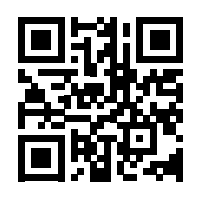

